\title{
COMMERCIAL
}

\section{RAW MATERIALS}




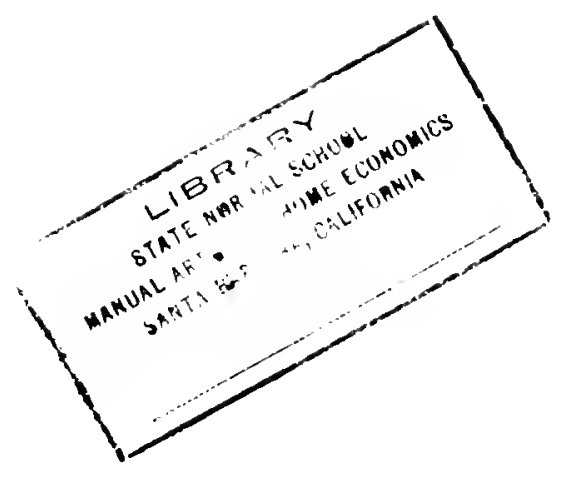


ads 




\section{Commercial Raw Materials}




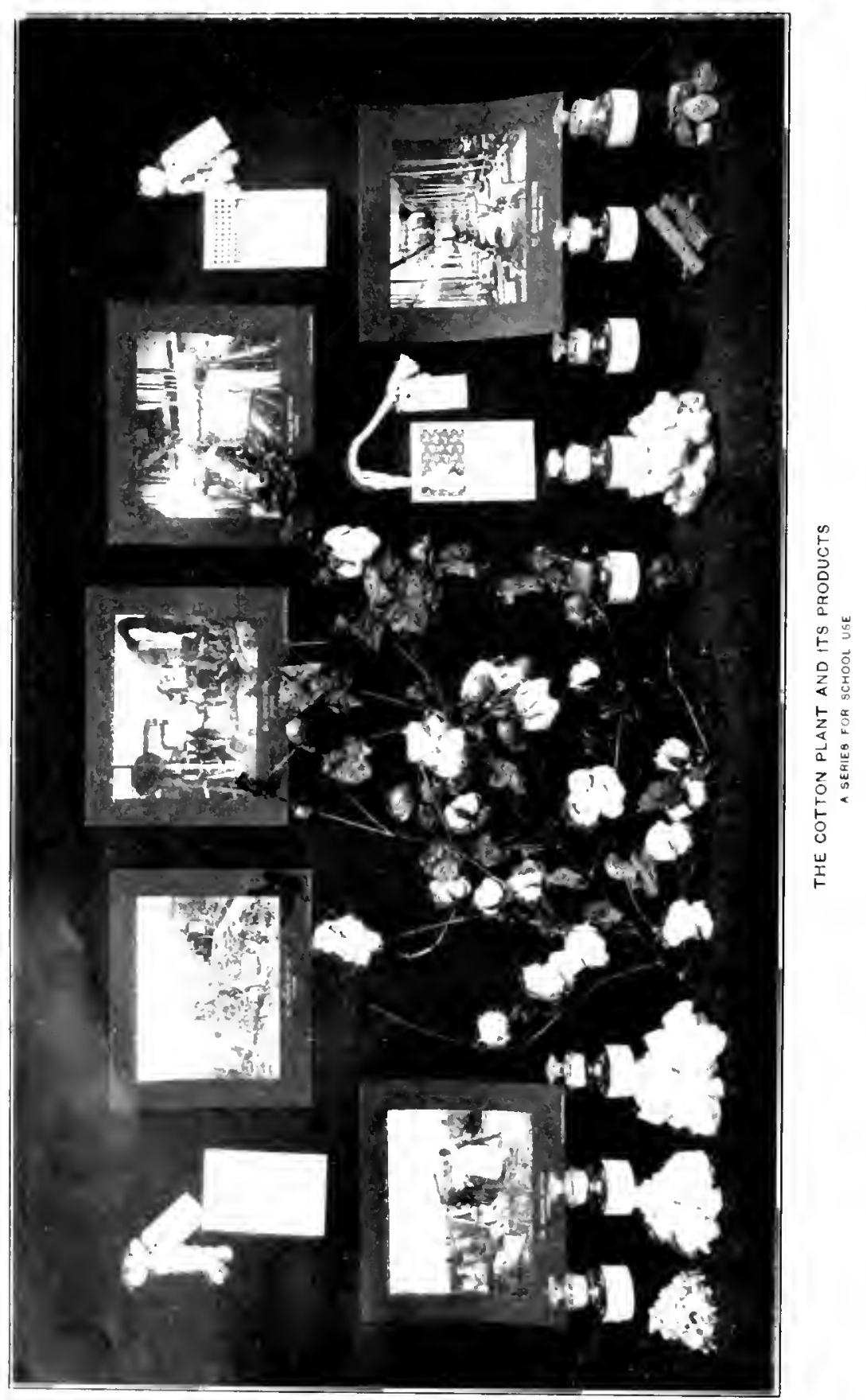




\section{COMMERCIAL \\ RAW MATERIALS}

Their Origin, Preparation and Uses

By CHARLES R. TOOTHAKER

Curator of the Philadelphia Museums

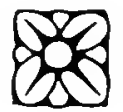

GINN \& COMPANY

BOSTON - NEW YORK - CHICAGO - LONDON 
COPYRIGHTED, 1905

the philadelphia museums

Philadelphia, Pa.

$45: 2$ 


\section{PREFACE}

The Philadelphia Musems are sromling to the public schools of Pennsylumia a series of collections of commercial products, charts, maps and photegraphs illustrating the commerce of the worlel and designed as an ald whe teaching of commercial gengraph and natural science. The distribution is made under state appropriations. The collections have been graded according to the work tome in the different schook, and different series are furnished for primary and secombary sebuls, regular high schows and ammercial high schouls. The standaril collection comprises twentyfive mils of commercial distributiom, wet one hundred ecomomic photographs and over thee hundreal commercial prolucts. This book was prepared primarily as a work of reference for the schook in connection with the use of these collections.

A consicleration of the mature and uses of the materials, which are of conomic importance and on which the luniness of the world and the life of it, preple are dependent, is a necessary purt of the study of crengraphy or commerce. Cntil recent years no schowh in this country hate systematically taken up the study of the procluets of the world, although courses along this line are essential parts of the currioula in many schwols in Eurnpe.

This book, which is hiefly descriptive of the origin, procesises of preparation and uses of the most importint commereial materials, will, it is hopect, aid teachers in all srutes whether they take up the products in a sperial comrse or only refer to them in cunnection with the comntries which prenluce them.

Nu classification of materints hats yet leen devised which is not open th some criticism. The grouping arlopted bere is inte sulstinces of regetible,

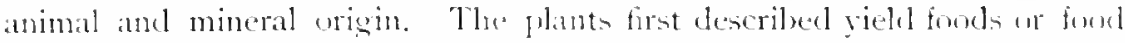
acessuries; folluwing these are plunts, such ats the cocoanut, which giveld louts foud and fiber; and then those, like the cotten plant, which supply E fiber, oil and cattle food. All of the materials obtained from one plant are

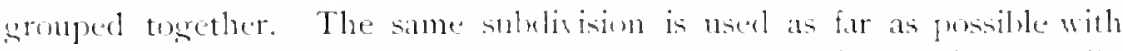
substances of animal and mincral origin. This classification is esenerally

Ifomml more comsenient amel Ixetter than the separation of the many different

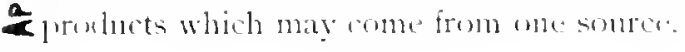


The naps of distribution show by their shading the parts of the world which produce the laresest amounts of the virious articles. The preparation of similar maps and charts showing the amount and relative importance of the materials produced, consumed, exported or imported will be found helpful to the student.

It is very desirable to use specimens in the class-room, in order to make the study of the world's products clear and profitable. It is of great importance for erery school to accumulate its own collection or museum, and much can be accomplished by the pupils as original work in the course of their studies. Specimens of many of the world's products are easily obtained by anyone. Teachers and children can get samples of many articles from merchants and manufacturers, who are usually glad to aid in the cause of education.

Helpful pictures illustrative of such subjects as agriculture, lumbering, fishing, mining, manufacturing in different ines, or transportation in connection with the products of various countries, are published from time to time in many magazines.

It is important that specimens in a school nuseum be carefully and accurately labelled, and that they be classified and preserved in sucl a way that they can be easily taken to the class-room, used and returned to their places.

The author has had unusual opportunities to become familiar with the things which make up the commerce of the world, through close contact with the Museums' collections. He is indebted to Mr. S. F. Aaron and Dr. 13. H. A. Groth, former members of the staft of the Nluseums, for valuable assistance throughout the work, as well as to Dr. William P. Wilson, Director of the Museums, for his helpful sugrgestions and good advice.

Frce use has, of course, been made of many standard works of reference in compiling information. 


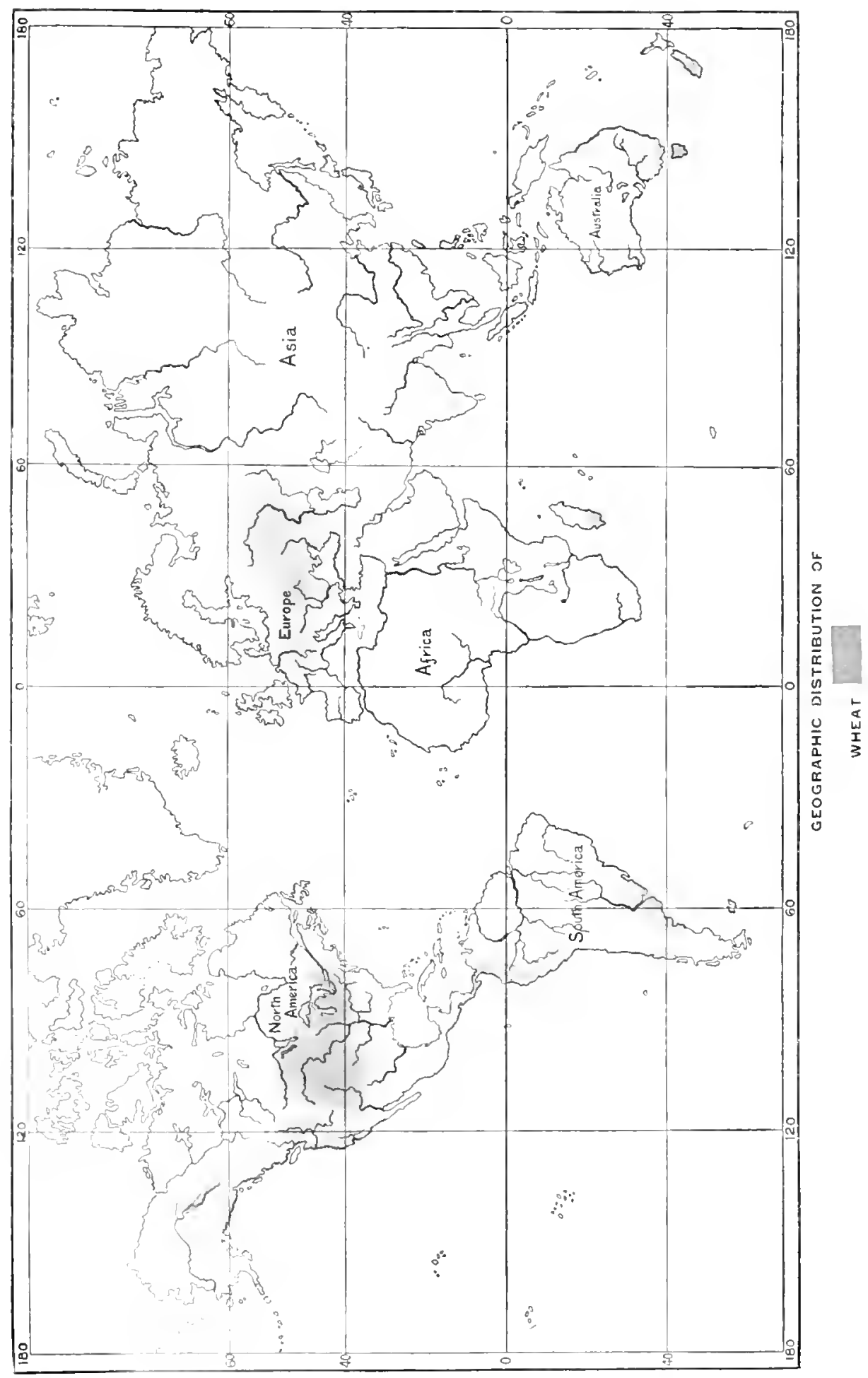




\section{VEGETABLE PRODUCTS.}

\section{FOODS.}

In most countries there is one foodstuff which, above all others, is considered the standard food, a food which the rich and poor eat alike. In the northern part of the United States and in the northwest of Europe this is wheat bread; in northeastern Europe it is rye bread; in parts of Ireland, potatoes; in Mexico, "frijoles" and maize; in southeastern Asia, rice; in many tropical islands, almost exclusively fruits such as the banana or the cocoanut. Usually the foods mentioned are the principal products of the respective countries. There are cases, however, where foreign transportation is so cheap that it furnishes a country with an imported standard food, as happens when salted fish are sent from New England and Canada to some of the West India Islands. Besides the standard and more important foods, there are everywhere many others of more or less importance : beverages, spices, fruits, etc. It is impossible to distinguish strictly between important foods and luxuries, for in Venezuela, for example, wheat flour is as much a luxury as pineapples are in Pennsylyania.

\section{Articles of Vegetable Origin Used as Food.}

For animal food: grains, fodder, hay, oil-cake, etc.

For human food: ccreals, and cereal products (grains, flour, bran, oatmeal, breakfast foods, macaroni, etc.); starch (from grains, roots, etc.); sugar (cane sugar, beet sugar, glucose, honey); iegetables, fruits, muts, fresh dried or preserved (peas, beans, potatoes, cabbage, tomatoes, apples, berries, grapes, pineapples, oranges, olives, almonds, chestnuts, etc. ); beicerages (tea, coffee, chocolate, postum, etc.); alcoholic liquors; spices and flazrors (pepper, ginger, cloves, cinnamon, etc., extracts, artificial flavors, condiments); iegetable oils, for table use (olive, cotton, etc.); medicincs (quinine, castor oil, etc.); stimulants (tobacco, opium, betel, etc).

Wheat (Triticum satioum, var. vulgare, durum, ctc.) is the

WHEAT most nutritious, and commercially the most important cereal.

It is the chief grain used for human food in western Europe, in North America, and by the white race in South Africa and Australia. It has been cultivated since very ancient times, and, in common with other grains, was referred to as " corn" before maize was known.

Wheat thrives best in temperate climates but is raised even in the cool mountainous regions of the tropics. The Inited States is the greatest wheat producing country because of favorable climate and soil, the use of improved agricultural machinery, and economical methods of handling and transportation. Wheat is handled in the United States largely in bulk; it is loaded loose (not in bags), on cars or in boats, transferred by machinery 


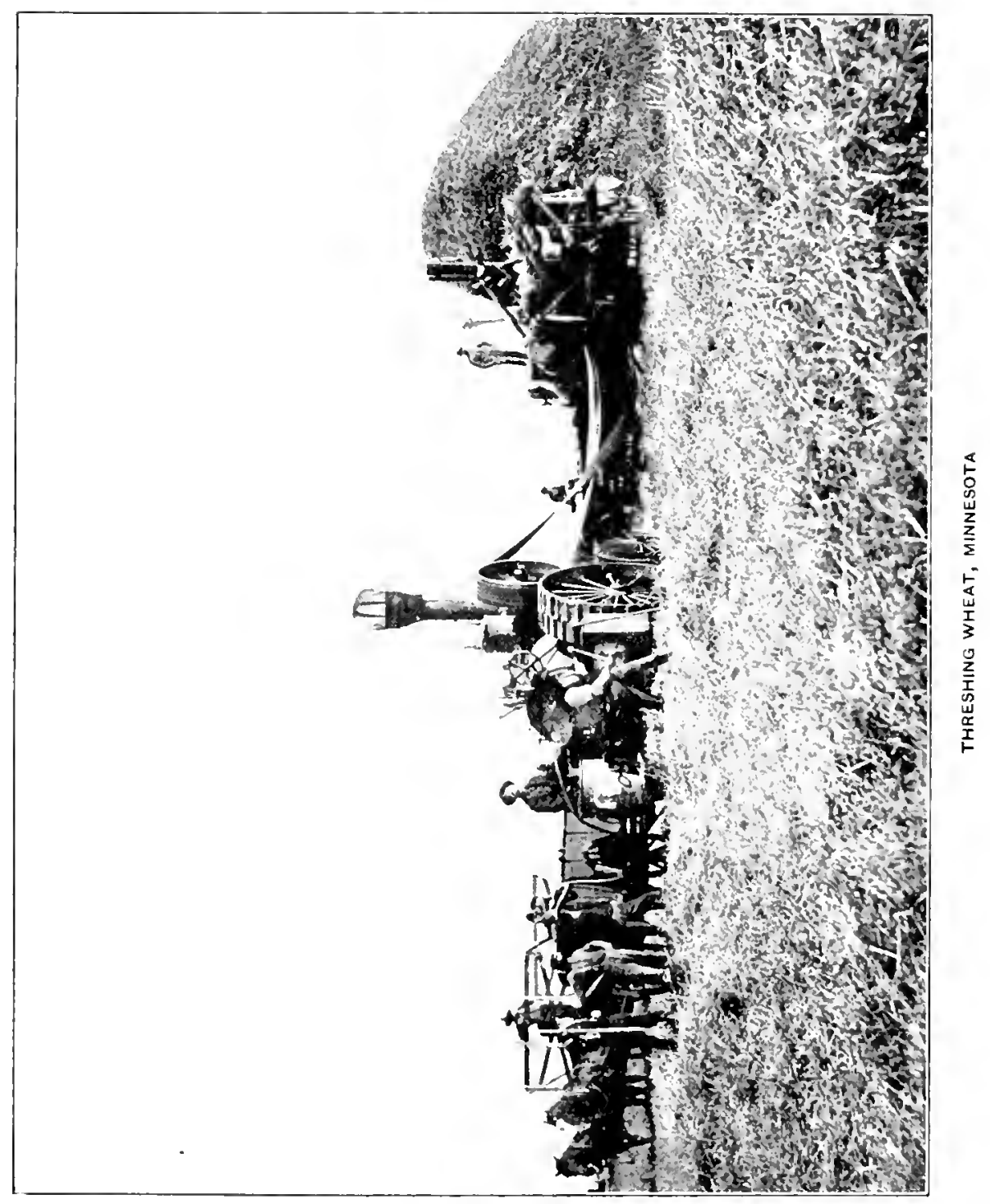


and stored in grain elevators. In other countries the grain is usually stored in bags and the cost of handling is, therefore, considerably greater. The European countries are all large producers of wheat, but only Russia and Hungary grow more than they need at home. The others must import it from them, or from the United States, India, Australia, or Argentina.

Wheat is classified commercially as "hard" or "soft." The hard varieties contain a large percentage of gluten or protein, and are suitable for making such foods as macaroni. Soft wheats contain more stirch and are used for making flour. Some flours are made of a mixture of hard and soft wheats. Wheats are also classified according to their color, "red" or "white," and according to their season, "winter" or "spring." Winter wheats are sown in autumn and harvested in early sumner: spring wheats are sown in the spring and harvested in late summer. The same wheat may be cultivated as a winter or spring variety, but when crown for generations as winter wheat it does not thrive as spring wheat and vice versa. Jike many other cultivated plants, wheat has developed hundreds of varieties, known to growers under different names.

Wheat is ground in great mills where heavy steel rollers have taken the place of the old style millstones. After grinding, it is separated by sieves and bolting cloth into bran, middlings and flour of different degrees of fineness. Minneapolis is the centre of the milling industry. Grits, starch, and breakfast foods are also made of wheat. Wheat straw is plaited for hat making. Leghorn braids are made in ltaly from the stalks of wheat, gathered while green and bleached in the sum.

Barley (Hordeum satizum, var. indgare, etc.) is chiefly used

BARLEY for beer brewing and in some places as loorse feed. It is cultivated in north and central Europe, as lar as northern Norway : in Tibet, northern China, Japan, and to a limited extent in the Lnited States. In warmer countries it thrives only in the mountains.

For household use, pearl barley is used in preparing soups, gruels, etc. In Scandinavia, harley flour is used for making bread.

Malt is male from barley (or sometimes from other grains) by spreading it, wet, on the floor of a dark room where it swells and sprouts. It is then dried, screened, groumd up, boiled with hops, and allowed to ferment to make beer. During the process of sprouting, or germination, a ferment, diastase, is produced, which converts the starch of the grain into dextrine and maltose. Naltose is a kind of sugar and this, in fermentation, produces alcohol.

Rye (Seale cercale) is the chief breadstuff in Russia, Scandinavia

RYE and parts of Cremany. It is cultivated like wheat, in "winter" and "spring" varieties, and grows in a colder climate and on poorer soil than wheat. Rye is one of the grains used in the Cnited States for making whiskey. In Russia, " vodka" is made from it. Rye straw is fong and tough and is used for making braids for hats, and to a less extent for making ropes and mats, and, by the poor people in parts of Europe, for 
thatching. Russia is the greatest producer of rye. The United States furnishes only a very small part of the world's production.

Oats (Arena satiza) is most important as horse feed. As oat-

OATS meal it is used for human food in Scotland, Ireland and other countries. It flourishes in a cooler and moister climate than wheat, and is grown over a large area. In this country, lllinois and Iowa are the greatest oat producing States. In Europe it grows most largely near the Baltic coasts of Russia and Germany and in Ireland, Scotland, France, Austria-Hungary and Norway. Russia and the United States grow more oats than other countrics.

Maize or Indian Corn (Zea may's) is largely used as a lood for

MAIZE live stock, the bulk of the crop being used in the West for this purpose. The principal corn producing States are Illinois, lowa, Nebraska, Kansas, Missouri, Indiana and Ohio. It is the most important human food in some sections of the southern United States, in Mexico, Central America, and in parts of Italy and Egypt. In Europe, maize is little cultivated and the name "corn" is applicd to wheat, oats, and other grains.

There are many varietics of maize varying in size, color, and composition; some are rich in starch and others in oil. The numerous varieties are due partly to the influence of soil and climate and partly to the efforts of the growers to develop certain characteristics, such as the large or small percentage of starch. Two types are distinct from all others, sweet or sugar corn, and pop-corn; these are grown in relatively small quantities compared with the total production of corm, and are used entirely for human food.

(For Corn Starch, see Starch, also Glucose, and Grape Sugar.)

During the process of starch making the germs of the corn are separated. These are placed in coarse cloths and pressed by machinery, until the oil is extracted. The material remaining, called oil-cake, is used for cattle food, and the oil is useful for soap making, lubricating, burning, and as a substitute for linseed oil in paints. Corn oil can be vulcanized (see Rubber) and then forms a substitute and adulterant for rubber. The actual value of corn oil is greater than the value of the starch itself, extracted from maize. Corn pith is used for jacking between the double lutls of ships, because when it absorbs water it swells up and thus closes a hole made by a cannon ball.

(See diagram of the Corn Plant on page 5.)

Rice (Oryza satiza) is the principal lood of one third of the

RICE people of the world. It is not so important as some other yrains in general commerce, because it is largely consumed in the countries which produce it. It is the principal crop and the main food in southeastern Asia from India to southern Japan and in many of the islands of the Pacific. The Lnited States prod ices in the southern states, chiefly Texas, Louisiana and South Carolina, about half as much rice as it consumes, importing the remainder from castern Asia.

There are several important kinds in cultivation: common rice, swamp rice, upland rice, and glutinous rice, besides several hundred minor varieties. 


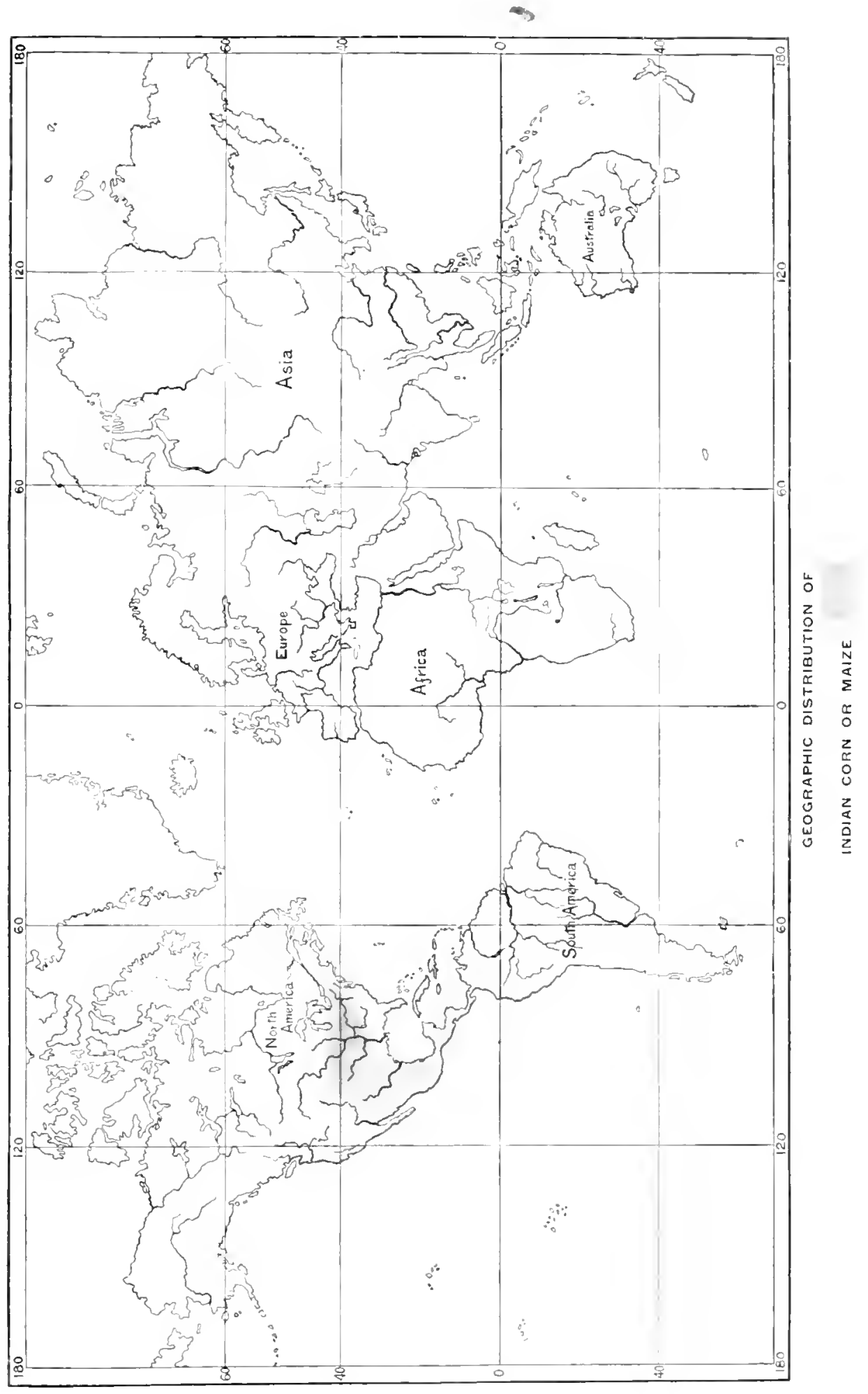





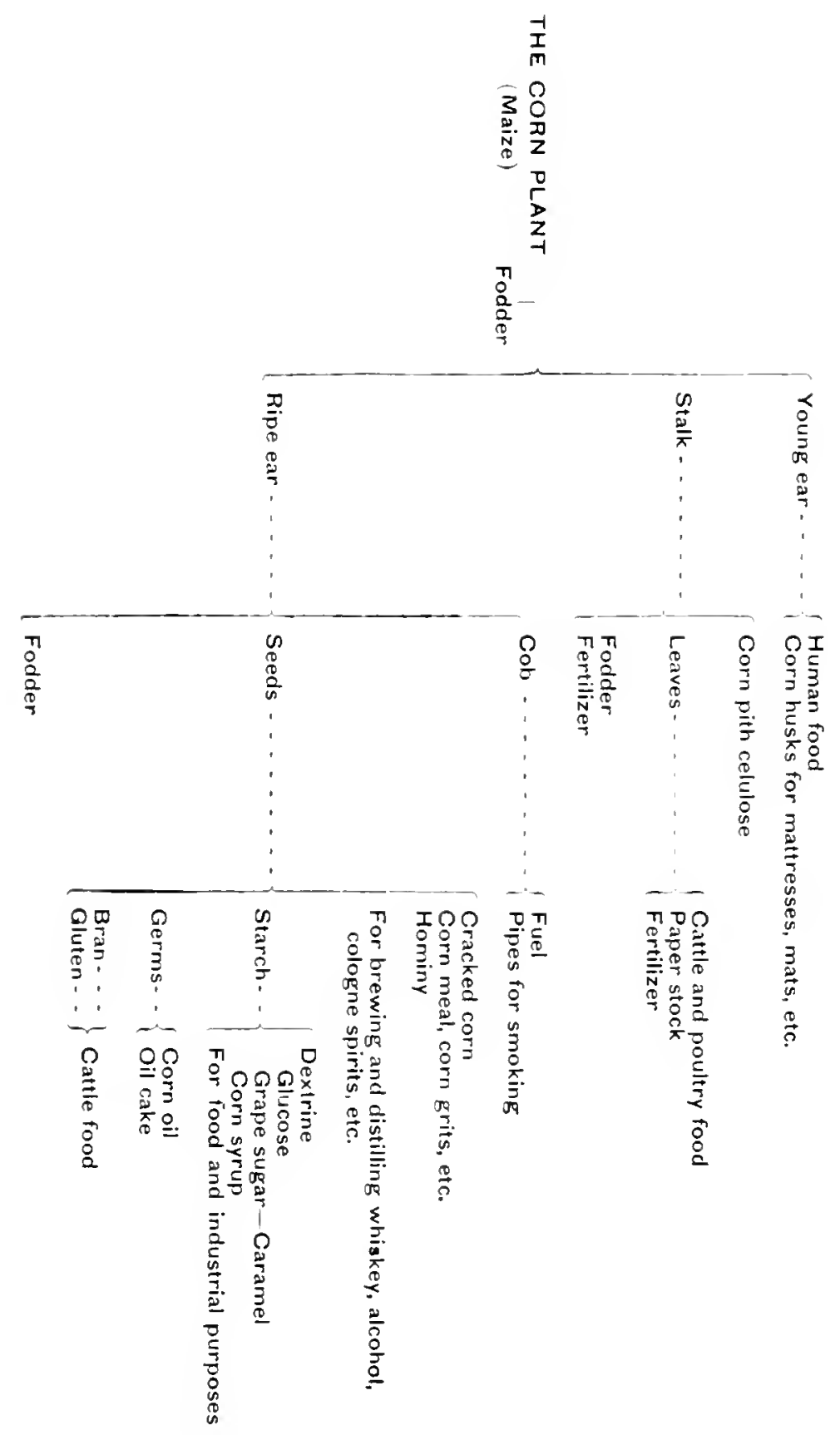


The crop is dependent upon a bountiful supply of moisture and a warmer climate than is necessiry for other grains. It is grown in swampy places or else in fields which an be kept flooded cluring the period of growth. Extensive irrigation has made it possible to grow rice successfully on the prairies of Lonisiana and Texas.

Rice with the hull on is called "padty." After the hulls are remored by rapidly rewlving millstones, the grains are polished or whitened by machinery. The grains which are broken in cleaning, although they contain just as much nutriment as the whole grains, sell at a very much lower price. The hulls are sometimes used as a packing material, or for fuel in the factory, and the rice flour or "polish" is a valuable by"product used for cattle food. Rice is richer in starch than any other cereal; the starch is extracted in much the same manner as from other grains (see Starch). Rice is used by the Japanese in brewing their national drink, a heverage called "saké." Rice paper (so called) is not made of rice but from the pith of an entirely different plant, although paper is sometimes made of rice straw. The straw is used in Japan and China for making mats, ropes, bags, sandals, rain coits, and other articles, and for thatching and bedding.

Buckwheat (Fugopyrum esculentum) although not a

BUCKWHEAT menber of the family of grasses, is usually regarded as a cercal because its seeds are used like those of wheat, rye, and other grains. It is used for feeding poultry and for making flour for luckwheat cakes. In this country, New York and Pennsylyania produce two thirds of the crop. It is cultivated in Russia, France, and Japan.

Millet is important as a lodder in nearly all parts of the world, MILLET and the grain is used for human food in Japan, China, and India. There are numerous varieties of millet, the commonest of which are European Broomcorn Millet (Panicum miliacum) and Foxtail Millet (Sctaria italica).

Sorghum is similar to millet. Its seeds are eaten, the juice of its stalks yields sugar (nee Sugar), and Broom Corn (Andropogon sorghum), one of its varieties, furnishes the stiff tops used for making ordinary brooms.

When a plant lays up reserve food for future use it usually

STARCH stores it in the form of starch. Frequently this is contained in secels or roots for the use of the young plant in the next generation. In each plant the starch grains have a characteristic shape and size, so that it is possible to identify the different starches ly means of the microscope. Starch is an important human food and is mostly eaten with the frart of the plant in which it is stored. From many seeds and roots it can be easily extracted. The common starches come from the seeds of corn, wheat, and sometimes from rice or other cereals or from heans; from the roots or tubers of potitoes, cassava (tapioca), arrowroot; or from the pith of the sago palm tree.

The process of separating starch consists of grinding or grating the material which contains it, and washing with water. The starch is not 


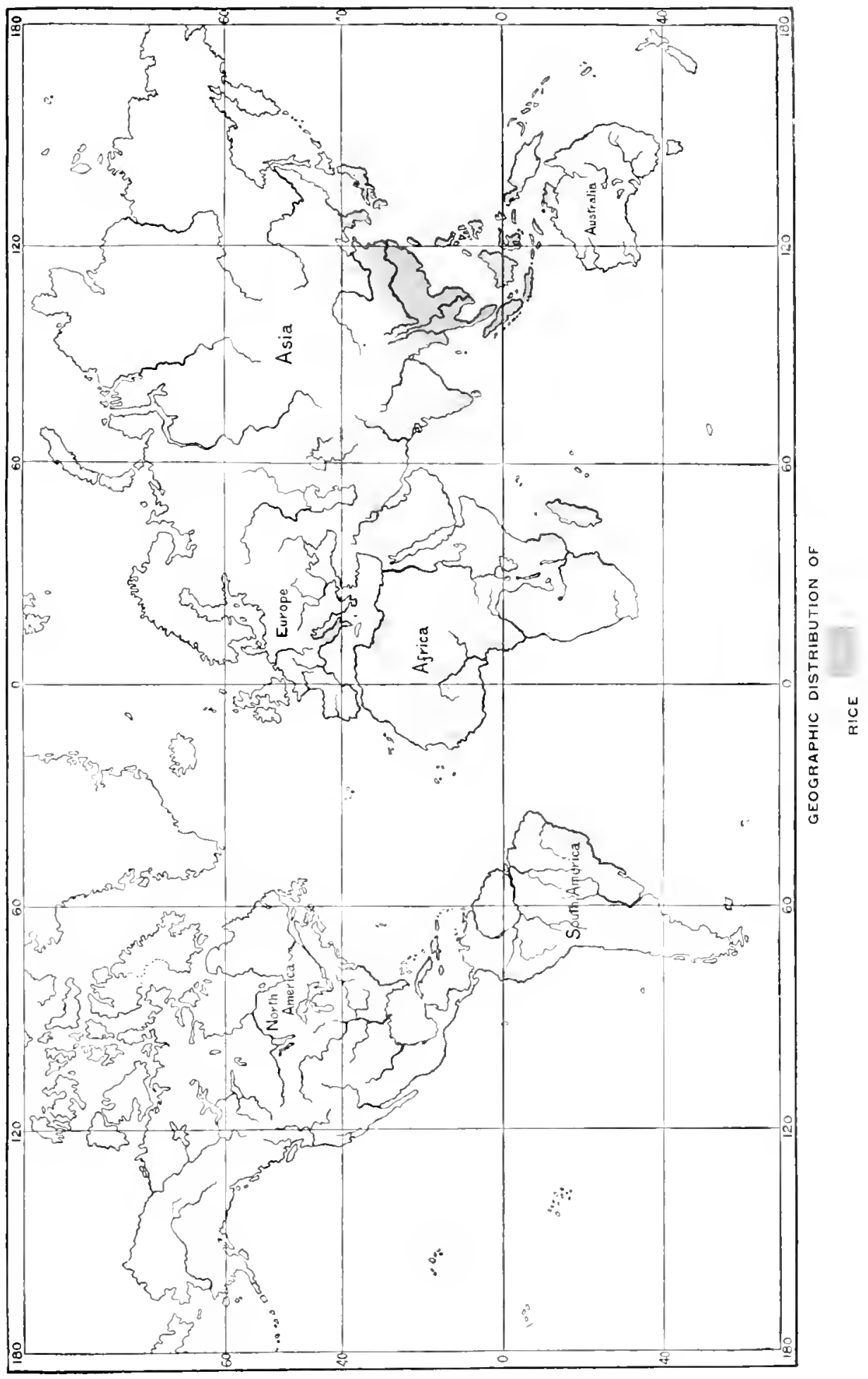




$$
\text { . }
$$


exactly soluble in cold water, but the grains mix reality with it and are easily carried off in suspension, so that the water with the starch can le strainet away from the more or less fibrous pulp. The starch settlen to the bottom when this milky lipuid is allowed to stand for a time, and the clear water is then drawn off and the starch dried. This process varies somewhat according to the material from which the starch is to be extracted ; wheat, for instance, is allowed to ferment slightly or is treated with caustic sinda to dissolve the gluten, while maize is soaked in water till the grain is softened before being ground up. When starch is extracted commercially on a targe scale, the factories are equipped with special machinery.

Corn and potatoes furnish most of the starch used in America and Europe, ant the by-products of starch-making are useful as cattle food, for distilling and other purposes (see Maize).

Tapricat starch is obtained from the roots of the cassara plant

TAPIOCA (Manihot utilissima). These roots contain in their juice a powerful poison, hydrocyanic or prussic acid, the sime substance which occurs in the leares of the shecp laurel. Fortunately this is easily removed by thorough washing or by heating, so that it does not remain in the prepared starch. Starch is used not only for food and in the laundry, but also finds numerous industrial applications, such as dressing cloth, sizing paper, making paste, etc.

Even more important are the substances made from starch, such as dextrine and grape sugar or glucose.

Dextrine, or "British Gum," is made from starch by roasting

DEXTRINE or by treatment with dilute aciels. It is a substance with properties like gum aralic, and is useful in making mucilage. for stiffening cotton textiles, for griving a gloss to palet and cardbuard, for thickening colors for calico printing, and for producing a "head" "m heer.

Grape Sugar is preparcel from starch by treatment with

GRAPE SUGAR lot dilute sulphuric acid. This changes the starch into al substance similar lo cane sugar, but not so sweet. It is a very important material, much used in brewing, and as a substitute for true sugar in syrups and cheap candies. Chemically, this sugar is known as dextrose. Commercially, the nameglucose is applied to the syrup of grape sugar. The same substance occurs in honey, in grapes, and in many other fruits The white substance offen seen on raisins is sralye sugar formed naturally.

Beans (Phaseolus zulgaris, ctc.) are a common article of food in

BEANS nearly all countries. In the American tropics "frijoles" are one of the chief staples, and flour made of beans is used in breadmaking. Beans are among the most nutritious fools, being rich in fleshforming constituents. String beans and marrewfat beans are gathered green, and both pods and seeds are eaten. By cultivation, the common table bean has been male to vary in size, taste, inlor, and composition. The varicties are known under different namess, suel as haricot beans, French beans, kidney beans, marrowfat heans. ate. lut all are derived from the same ancestral stock. The Lima bean, the seijat or soy bean, the pigeon 
bean, the greengram, and others are different species. Soy beans are used in eastern Asia for making bean oil. Some heans are used, in making starch.

P'eas of several varieties (Pisum ariense, satizem, etc.) are im-

PEAS portant as fouds, and are cultivated in nearly all parts of the world. Chick peas, or "uarbanzos" (Cicer arietinum), are larger than the common pea and are grown in Nexicu. Central America and southern Europe. Lentils and vetehes are common foods in many parts of the world. They bekng. with beans and peas, to the group known as legumes.

Sugar is olvained from the juice of the sugar cane (Sackarum

SUGAR officinarmm) and from the juice of the sugar beet (Beta anugaris). The sugar from these two sources is in every way identical, and is mot different in sweetness. Chemically, this substance is known as cane sugar, whether it comes from cane or heet. 10 distinguish it from grape or other sugars. Two thirds of the sugar used is now derived from leets. Java, Cula, Hawaii, Brazil, Mauritius, Oueensland and Louisiana are the principal places which produce sugar from cane. Germany, Austria, France. Russia, Belgium, and Holland are the important beetsugar producers.

In extracting sugar from cane, the fresh stalks, which contain as much as go per cent. of juice, are crushed between powerful steet rollers. The juice when pressed out is heated and clarified by adding a little lime, and then woes to the evaporating pans where it is bented. usually in a partial vacuum, to prevent orerheating and hasten the concentration. When the liquor has sufficiently evaporated, the sugar crystallizes out and is separated Irom the molasses in centrifugal machines. The raw sugar resulting from this process is shipped to refineries, most of which are located in the United States and in England, where it is dissolved and purified by treatment with lime, the serum of blood and filters of bone-llack. Tpon re-crystallization it in perfectly white, and appears on the market as gramulated, loaf, or pulverizel sugar. Sugar beets are usually rasped and then pressed to extract the juice, or the sliced thin and soaked in warm water. The juice is evapurated and the raw sugar is refined in the same manner ats in the corresponding process of treating the juice of cane.

Rum is make in the IVest Indies by fermentation and distillation of the juice of the sugar cane.

The world consumes more sugar every year, and the percentage of beet sugar in the lotal product is steadily increasing. This is due partly to the fact that heets are arown in densely populated countries, where the sugar fucls a market at once, thus saving the cost of transportation: partly to the fact that the refum or pulp from the beets is a valuable food for rattle: and 1:uty w the asmistance wiven by European governments to the beet-sugar industry in the shape of bounties to producers. Some sugar is obtained from other sturces, such at maphe sugar in the northeastern Linited States. and sorghum sugar from the stalks of brom-corn, cultivated in northern India. China, and fapan, and in the central part of the United States. The 


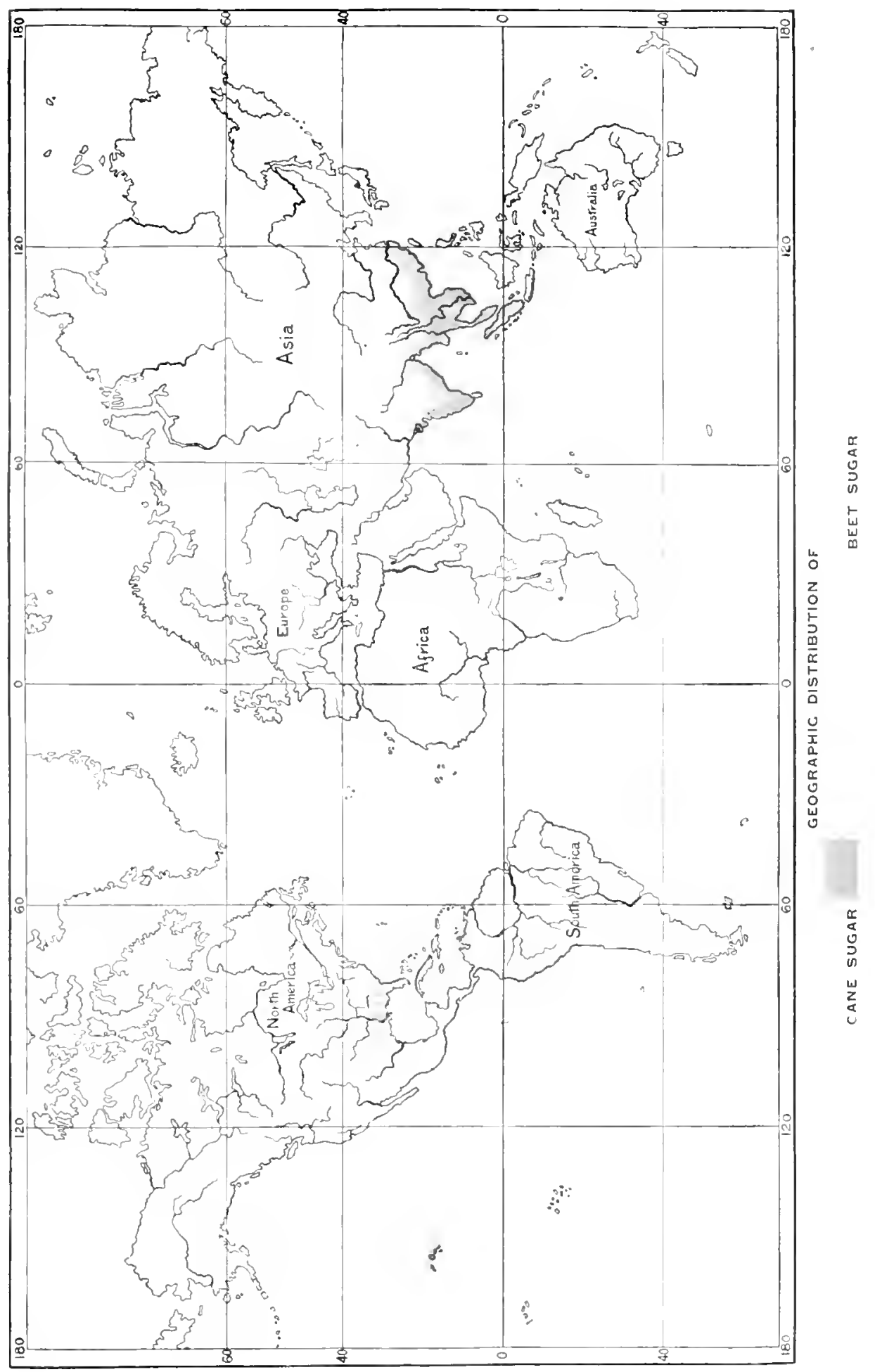






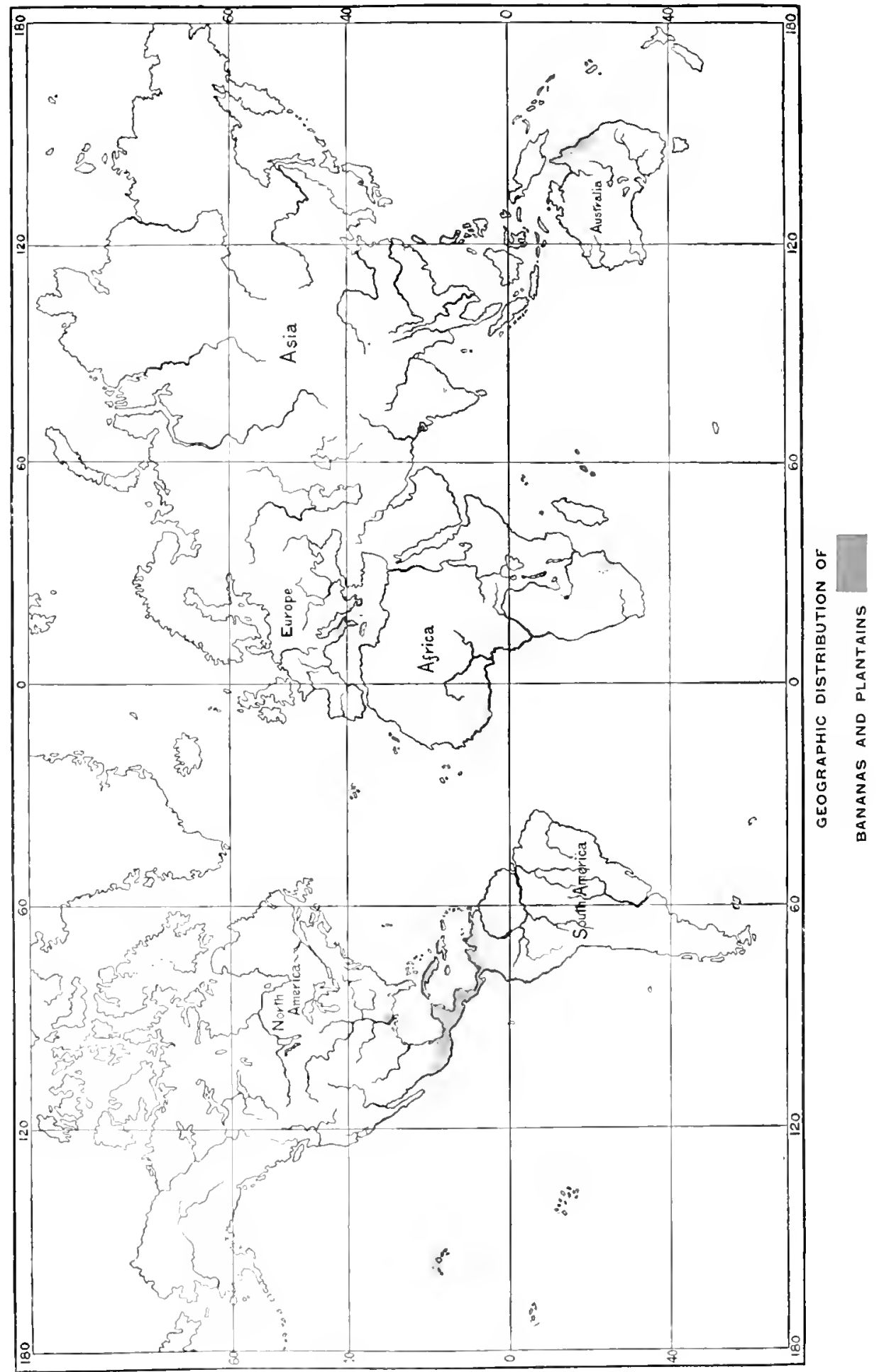


sugar from sorchum is difficult to crystallize and is, therefore, generally used in the form of syup.

"Jasgery" is a sugar olitimed locally from the juice of certain palm trees. Cirape sugar is less sweet than cane sugar and is commonly male from starch (see Grape Sugar). Laevulose or fruit sugar, lactose on milk sugar, and maltose, or the sugar produced in malt, are not of gencral commercial importance.

Vegetalles and fruits for table use are important in local VEGETABLES trakle, especially in the neighborhood of dense populaand FRUITS tions, but do not play as great a part in the world's commerce as less perishalle materials. large quantities of regetables are shipped from some European countries and from islands which, like the Canaries and Bermuda, have a faverable climate and a sitnation convenient to markets. Refrigerator ars make it possille to ship vegetables and fruit from places as distant as California and Fkricla to the North Atlantic scaboart. Oranges, pineapples, binanas, cocoanuts, anel other tropical fruits are important foods whore they wrow. large fuantities are shipped from the West Indies and Central America to the Inited States and Europe. Apples, both green and lried, are among the important exports from the United States.

\section{BEVERAGES.}

Tea is produced in China, India, Ceylon. Japan, and Java. It is TEA cultivated in small plantations in South Carolina, Jamaica, Natal, and other localities. Outsicte of the eastern countries which proInce it, tea is consumed principally in the Cnited Kingtom, the British Colonies, Russia, and the United State's.

The tea plant (Thea chinensis) is usually kept trimmed fown to a small bush. Only the poung leaves are picked. In some countries where the plant grows rapilly, the pickings are frequent, while in more northern districts the leaves can be picked only once or twice a year. The processes of preparing the leaves differ considerably in various places, and naturally result in teas of different qualities and favors. In general, after the leaves are picked, if they are on be made into black tea, they are allowed to wither and ferment slighty, and then iricel, uswally over a charcoal fire. Green teas are prepared by drying the leaves more quickly and not allowing them to ferment, as in the mamufacture of black teat.

Teas are classed commercially acourding to their color, sreen or black ; according to the rlistrict producing them, as Japan, Formosa, Ceylom, China, India, Assam, etc: according to the method of preparation, siving " Gunpoweker," "Imperial," "Hyson," "Caper," etc., Sun-elried, Pan-fired, Basket-fired, etc : and accurding to the guality, dependent on the aye of the leaf, as "Pekoe," "rolong," "Sinchong," "Congens,"

When tea is treated with hon water, the stimulating element a theme or

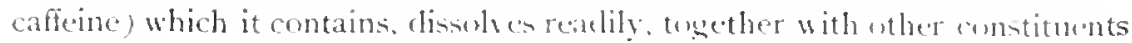




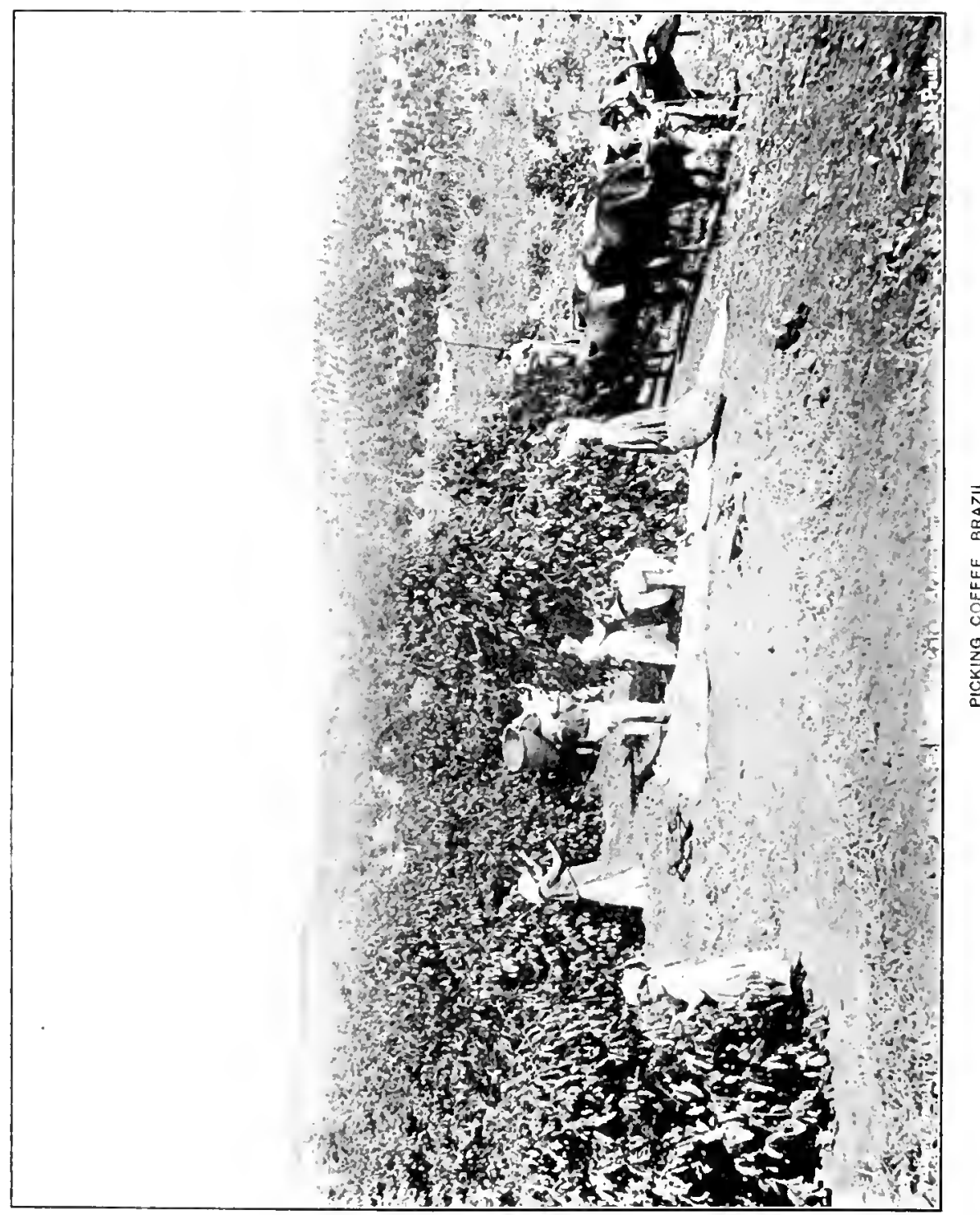





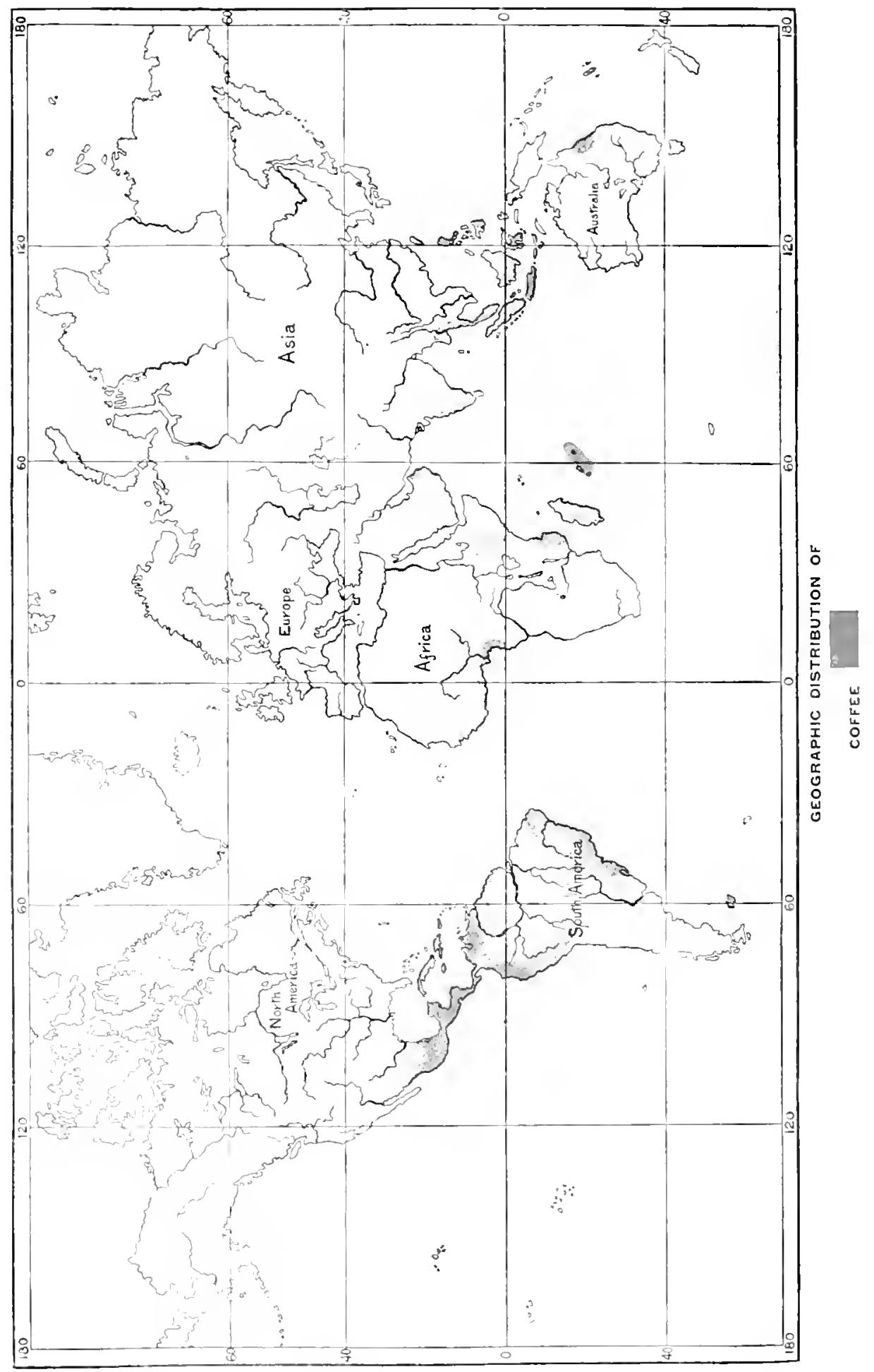


which give to the elrink its taste and aromat Tea leaves contain alse tamnin and this clissolves out upon long standing or upon builing. Tamnin is the substance which is contained in many harks ancl is used to transform skins intw leather, and when it clissolves out of the leaves, gives to tea a hitter taste.

Yerba Maté or Paranuay Tea is used like tea in Parat

YERBA MATE suay, Lruguay, Arentina and southern Brabil, It consists of the dried leates of a tree (Mex parangayensis) of the bolly family, which stows whle in that part of the world. It combans caffeine (theine), the same stimulating principle which is found in tea and coffees. In collecting maté. branches are cout from the trees, dried over a fire: and then the leaves and mall twigs are pumbled to a coarse pouder. It is often sewed up, in hags made of the skim of freshly -killed cattle, at treatment which the natives think adds to its pleasant flaver. In some larewe fatcturies it is prepared more carefully, and packed in kegs an cans for shipment. The natives of the lower class, whore the chief consumers, prepare the tea hy pouring hot water on the broken leares, am drink it by sucking thomern a "bombilla" or metal tube with a sieve at its fower encl.

Cuffee is arown principally in Brazil. Less than one quarter COFFEE of the world's product is raised in other combtries, chicfly Venezuela, Central America, Jana, Mexico, and the Mest Indies. The Lnited States uses more onfeet than any other country.

Coffee is the seed of a shrub or small tree (Coffea arabiad, C. liberiar) which is usually kept trimmeal to a height of cight or ten feet for comvenience in picking. The berries when ripe are bright red in color and alout the size of a cherry. They comtain two secels, each cosered by a thin ment bran (the "silver skin"), then hy a thick, twugh skin the "quathment" (1) "cascara"), and the whole enclesent in a pulp which holds the two boun with their that sides truether. Some herres, growing on the same plants as the others, contain but one bean, which is round insteat of flut, and is called "pearl" or "male-berry" coffee. After picking, the berries are pulped hy a machine, washed, and allewed to lie in tank till the acther. ins fuj, soltens. They are then washed clean, and spreal on cement or earthen fhors in the sun to dry. A cleaning machine next breake and remones the "parchment," which has become britte on dryins. Further cleming removes the "silver skin" and pulishes the beans. making them reacly for market.

The principat commercial varieties are named from the places of production or shipment, as Mocha, Java, Rio, Santos, I a Guayra, Guatemala. etc. Mocha and Java coffees may he grown in any country, the ne names heing applied to coffee having a tlaver like the kincls which were wisinally grown in those places. liberian eoffec is poduced in many countries hy the Liberian coffece tree.

The characteristic flator of coffee is developed ly roasting the heans. The mating is usually done near the plate of consumption, not long before the roffere is to be used. 
Chicory roots, when ruasted and ground, are used as

CHICORY ROOTS a sulstitute or as an alulterant for coffee. Some pressons find coffee hambul, and prefer to use chicory or some other substance, such at roasted barley, to make a lrink, since these things do not contain catfeine, the stimulating principle found in coffee, tea, and chocolate. The chicry plant (Cichorium intybus) has a pale blue flower, anel is a common weed along roadsides. Nuch of the chicory used is importeel from Gromany and France, lut there are several factories for its preparation in the Lnited States.

Cacan, heans are the sonrce of cocoa and chocolate. CACAO BEANS Fcuador exports mure cacao beans than any other comntry. Venezuela, Brazil, Nexico, Trinidad, the East Indies, and Ceylon are important producers.

The fruits of the cacao tree (Theobroma cacao) are six to ten inches in length, with thick, leathery rinds, and each contains filty or more seeds, usually called heans. In some places the seeds, after removal from the pods, are preparrd by simply (lyying in the sum. In other places they are piled up, or buried in arth, and before being dried, undergo several day's' fermentation, which, it is helieved, develogs the flavor and aroma. In conmerce both the unfermented and the fermented, or " rotted" beans are extensively used, although lemented beans are considered the best. In the trade, beans are known from their locality of production or shipment, as Esmeralda, Guayaquil, Caracis, Surinam, Nexican, Bahia, etc.

In the process of mannficture, cacao beans are first roasted and then crushed, breaking readily into small pieces. The shells are winnowed out, learing the framments of beans known, commercially, as cocoa nibs.

Bitter checolate is made ly grincling cocoa nibs to a fine, smooth paste, which is moulded in cakes; sugar is added to make sweet chocolate, which is often flavored with vanilla. Pure chocolate contains about fifty per cent. if (ill

Cocal poweler is prepared by heating and pressing cocoa nibs in a powerful machine till some of this oil or lat is removed, or by treating chocolate with alkalis, which act on the oil and make easier the mixture of the powder with water or milk in making at drink. The oil, starch, and albumimicls montained in chocolate and cocon rencler them very nutritious, and at snall amount of theolmomine (which is similar to caffeine) gives them a milslly stimulating effect.

Cur biater, the soliel cil extracted in the manufacture of cocoa fmoler, is very importint for the manufacture of medicinal salves, since it flose mot casily Inenme rancid. The thin shells broken off the outside of cacio beans are the d to some axtent in making a beverage.

Alcoholic lipuors are very important from a ALCOHOLIC LIQUORS inmmercial and inclustrial standpeint. Wines of many srates are marle, mostly from grapes, ly fermentation of the juice. France, ltaly and spain are the great wine comntries. Califunia and rew lork produce most of the wine mate in the 


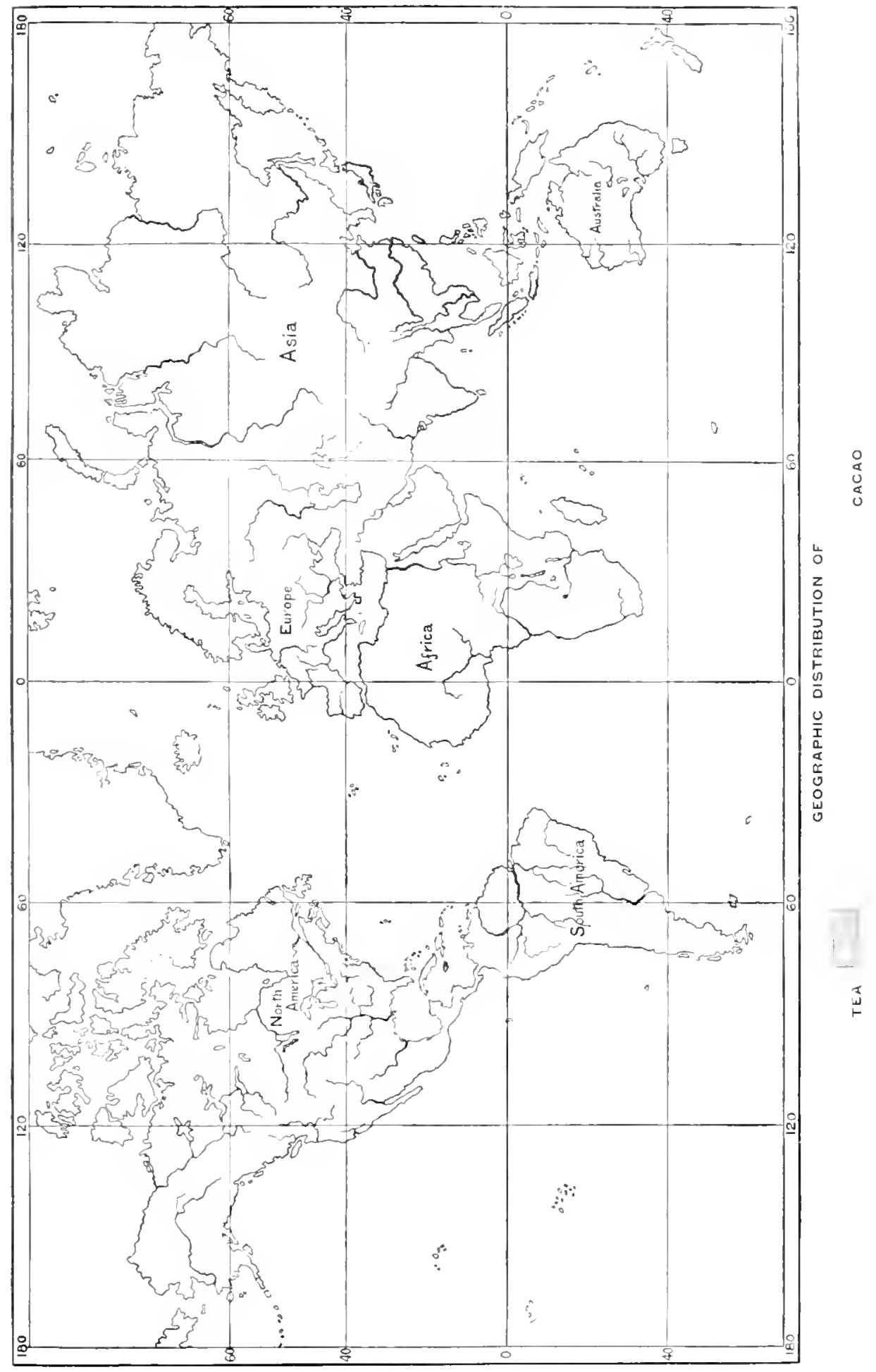



United States. In fermentation, sugar is changed inte alcohol. The sugar may be the datural sugar of fruit or canc, or may lue shlucose prepared from starch (see Barley, Malt, and Grape Sugar).

Fermented liquors vicld strong alcolwhes by distillation. bramely is distilled from wine, and rum from the fermented juice of slyall rine. Whiskey is listillet from fomented grim, scuerally either orn or rye. By careful re-clistillation pure alcohol is obtained.

All parts of the worlel use more or less alcoholie liepurs. The farorite beverage in Japan is saké, a wine makle of rice: in Mlexien it is puldué, the fermented juice of the century plant: in parts of ludia and some of the Pacific Islands it is "tully" or "tuba," from the silp of the cocmant palm; and many other conntries have their peculiar drinks. In nearly all civilized comtries taxation of the manufature and trade in alcoholic licpors is one of the important sources of public resume.

Hops are used chetly in brewing. They are the elricel fruts of

HOPS the hop vine (I/umulus hupulus) and are raised in the. Enited

States in California, Oregon, Washingtom, New York and Wisconsin. They are cultivated in most comberies of Europe, but especially England, Germany, and Austria. Hops are anleded to the malt liguor or "wort" (sce Barley), which is then boiled, and afterward fermented by adding brewer's yeast. After two or three day' fermentation the beer is freed from the feast, placel in settlins tanks, and clarified before being placed in kegs or bottles. Hops give a bitter flavor to malt liquors.

\section{SPICES.}

Mustard is the most common and commercially, the most inportant spice. Several plants belonging botanically to the genera, Brassied and Sinapis, produce mustard seed. They grow in most parts of MUSTARD Euroje amel the ['nited States, as well as in Asia and the Farst Inclies. The seeds vary in color, heing llack, brown, red, yellow, and white. Blark amb gellow mustard are thw most important kinds. When the sueds are pressed they gichel an oil. which in India is used for

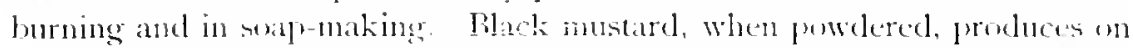
mixing with water a very pungent essential sil. This oil is not formed by white or gellow mustud, but is poluced in larger quantities ly a mistme of the black and yellow. To this oil is che the pungent smell and taste of ground and prepared mustard and its intlammatory artion on the skin.

lepper, one of the common spices, comes mostly from Singa-

PEPPER pore. The two kinds, hack and white pepper, are probhed by the same vine (Piper nigmm). The lerries are wathered when they lexin to turn red, picked, cleaned, and hried for several disy on mats in the sut, or in bambon baskets hefore a gentle fire. This mole of preparation gives lolack pepper, as in drying, the pulp, slurivels and turns black. For white pepper the berries are allwwed to ripen on the vines, and are then hruised and wasled free from the pulp before drying. Long 
pepers, the young fruits of a similat vine (Pifor longum) when yround are sold as black pepper. J'epjer is one of the spices earliest used by mankind, and although now a commodity of but small importance in comparison with sugar, cotton, or coffee, it was for a long time the staple article of trade between India and Europe, having a very important place in that commerce at the time of the discusery of America.

Red pepper or Caycnne pepper is the fruit of a plant (Capsicum species) of a different genus. It is grown throughout the civilized world, being used in large quantities in Nexico. Central and South America.

Allspice or "Pimento" is the dried unripe Iruit of a tree ALLSPICE (Pimenta officinalis) which is cultivated chiefly in Jamaica. It is sathered by breaking of twigs bearing bunches of the berries, and drying them in the sun. Its extensive use as a flavoring is due to its cheapness. The name pimenta is commonly applied to peppers and other spices.

Caraway seeds are used in flavoring bread, cakes,

CARAWAY SEEDS and liquors. The small herb (Camm carvi) which produces them is grown in northern and central Europe and Asia as well as in the United States.

Cloves are the dried, unopened flower buds of a tree (Jambosa CLOVES carrophyllus) which originally grew in the Nolucca Islands. Zanzibar and the neigluboring island of Pemba are the source of most of the commercial supply, althongh cloves come also irom Amboina and near-ly islands of the Molucca group, from Sumatra, Reunion, Mauritius, and other islands of the East and Vest Indies. In Zanzibar, each cove is picked separately, a moveable stage being used to enable the pickers to reach the upper branches. In other places the buds are oiten beaten off the trees on to cloths spread beneath. Cloves are used as a spice for food, confectionery, and liquors. Close oil, obtained by distillation with water, is used for the same purposes, and in medicine and dentistry.

Nutmegrs are the kernels of the fruit of a small tree NUTMEGS (Myristica fragrans) which is cultivated in the Banda Islands and other parts of the East Indies, in Zanzibar, Remion, the West Indies and South America. The kernels grow covered with a thin shell, which is in turn cnveloped in a bright red, lace-like seed coat, within the pulp of a fruit which looks like a small pear. The red seedcoat when dried is the mace of commerce. Nutmegs are usually coated with lime th give them a white appearance.

Vinillis is produced in greatest amount and of best quality in VANILLA the State of Vera Cruz, Mexien. It is gromm also on the islankls of Reunion, Nanritius, and Tahiti, and in small quantities in a fow ufher flaces. It is the pregared umpe fruit of a kind of

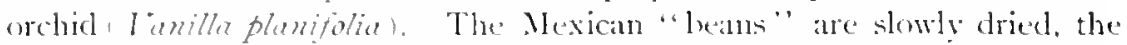
froces taking seremal weeks; they are allowed to ferment slighty, and

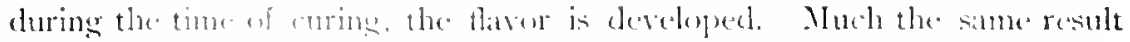
is arriced at $n$ a more raphel mamer by the use of hot water or calcium 
chloride in other processes used in Bourbon and Tahiti, hut such leams do not bring so high a price. Vanilla and vanilla extracts are used for tlavering chuculate, ice-cream, cakes, candies, ete. The poorer prates are userl extensively to flavor chewing tobaco.

Tonka beans have been used to adulterate vanilla, and in making varilla extracts. They are on the market now only in small fuantity, being displaced ly cheap graeles of truc vanilla. Vanillon is an artificial ranilla extract. It has been marle of conal tar, hut is mow mannfactured in large quantities in the United States from oil of cloves.

Ginger consists of the dried root-stalks of the ginger plant

GINGER (Zingiber officinale). It is smon in most tropical comutries, particularly in Bengal, Cochin China, China, Africa, and Jamaica. It is found in commerce in two dasse's- "conted," and "uncuated" or "peeted." Coated gringer is produced by drying the green rusts in the sun. Encoated ginger has been washed and peeled, or scraped, before being dried, and is wswally bleached and covered with lime. Ginger is used as a flavoring and stimulant in fonds and in drinks like ginger ale, and is often preserved in syrup, or candied for use as a sweetmeat.

Turmeric consists of the underground stems of a plant of

TURMERIC the ginger fanily (Curoma longa). It is grown in southeastern A sia anel the neishloring islands. It is an important contiment used in curry powder. In solution it gives a heautiful yellow dye fin cotton goods. Tamners use turmeric in preparing fancy leathers, and chemists use paper colored with it in testing for alkalis and for boric acid.

Cinnamon is the dried hark from the young twigs at a tree

CINNAMON (Cimamomum zeylanicum), which grows in Ceyton. Clinese cinnamon or cassia bark comes from similat trees which srow in China, northern India, and other places. It is inferior to the true cimamom, but is much more common.

There are other less important spices, such as carlamom, coriander, anise, and pistachio, besiles many things such as sarsaparilla, fruit juices, and extracts, aloes, and essential oils used for flavoring. Many flavoring materials, extracts, etc., are mate artifinally in the chemical laboratory.

\section{OILS.}

Vegetable oils of many kinds are used for fook and for comking. In

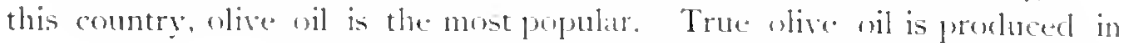
Meeliteranean countries and in California. It is

VEGETABLE OILS often adulterated with oil from cottun seeds. (Sce Cistem., In other parts of the worlet, oils oluained by pressing other serects, such as peanuts and sesame, are extensively useel. (See Oils and Oilseets.) 


\section{MEDICINES AND STIMULANTS.}

Medicines are ohtained from the flowers, secels, leates, gums, twigs, bark, or routs of many plants and trees. The crucle substances which yield medicines are called drugs. The bark or other part of the

MEDICINES flant is ustually ground up and soaked in water to dissolve out the medicinal principle. Ouinine, sarsaparilla, licorice, coca, nux, oplum, aconite, annica, belladonna, ipecac, rhubarl and others are familiar cxamples. They are obtained in various parts of the world, and their production in sume flices is very important, as in Jara, where most of the fuinine bark comes from. Some seeds, like castor beans, viekd oil with medicinal properties. Some sulstances of animal origin and many of mineral origin, such as salts of arsenic, irom, and mercury, and wher compuncls mate from coal tar, such as antipyrine, are of great medicinal value. Medicinal substances and prepared medicines are an important item in both the imports and exports of the l'nited States.

Toluece is the most extensirely used narcotic. It was

TOBACCO wisinally a native of America, and has spreal over the entire world since the year 1600 . It is now used commonly mit inly by civized peoples but also by savage tribes in the interior of Arrica and by Chinese and other peoples, in districts where moxlern civilization and commerce have not penetrated. The many gradations in the quality and flavor of tobaco are due to differences in soil, climate, and cultivation.

When the plant (Nicotiana tabacum) is mature it is cut and hung "p in open buildings to dry. The "curing" of the leaf, which includes a period of light fomentation, gives to it its characteristic whor. The flavor of nearly all rut tolucco and chewing tolacen is altered by the use of molasses, lienrice, vanilla, or nther sulistances. Only the best leaves can be used for making cigars. The stems or midribs of the leaves are used for low grakles of smoking tobacen and snufi, for making sheep-dip, and for fumigating arcenhousts.

The varieties are known commereially from their localities of export or prometion, as Harana, Sumatra, Mexican, Turkish, Virginia, etc. Nuch

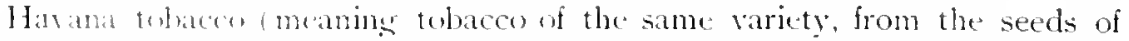
Cubm phants) is raiser in Comnerticut and elsewhere in the United States.

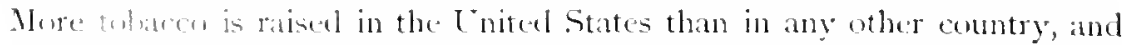
ove half of the probluct is exported, mostly to Enyland. In Europe it is cultivated juineipally in Austria-llungary, Russia, Gemany, Netherlands, Belsimm, and Turkiy. Culu, lourto Rico, Mexico, Central and South America, Imelia, China, Jana, Sumatra, the Philippines, Ceylon, and Cape Colony are impuntant froducers. Large reventes are raised in many cementries from the titation of tolvaceo.

('pium, in aldition to its medicinal value, as the source of

OPIUM lintiunum and morphine, is extensively used as a narcotic in China and the Fast. It is the dried juice of the white popply (Papazer somnifermm, whatined by scratehing the seed capsule. The juice 
exudes in small drops and is collected. Its production is an impuntant industry in northern India, China, lersia, and Asiatic Turkey. The Chinese, who consume more than any other people, smoke opium in small pipes, and it is taken in pills in Persia and Turkey. The government of India secures a revenue of over \$10,000,000 yearly from the opinm trak. The Lnited States inports opinu for medicinal purposes from Turkey.

Areca nuts, sometimes called betel nuts, are chewed by ARECA NUTS the perple of India and by the Mlalays and Chinese throughout southeastern Asia and the East Indies. The nuts, the seeds of the areca palm tree (Arca catchu) are boiled, sliced, a little lime is added, and the mixture is chewed with a leaf of betel pepper. Areca nuts are also used in medicine.

Coca leaves, the source of cocaine, are mixed with COCA LEAves lime and chewed ly the natives in Bolivia and noiglboring comtries. They come from the cucal tree (Erythroxylon coca).

Kola nuts (Cola acuminata) are grown in Africa and the KOLA NUTS West Indies. The Airicans chew them for their stimumedicinal qualities.

lating effect. Kola wine and syrup are valued for their

\section{VEGETABLE FIBERS.}

From leaves and leaf-stalks- Manila hemp, anave fibers, New Zealand flax, raphia, palmetto, (te.) : from the hast of plants-(flax, hemp, jute, ramie, linden bast, etc. 1; from fruits-(cocuanut, luffa 1: from plant hairs-(cotton, silk cotton); artificially prepared fiher-(paper, artificial silk : from whole stems or parts of flants-(straws brom corn. Spanish moss, rattain, etc. '.

(For animal fibers see Silk. IVool. etc. and for mineral fibers see Asbestos.

Many fibers especially those nsed for ropes and brushes, are wiled to make them flexible and to keep them from becoming dry and brittle.

Manila bemp is the strongest rope fiber in common use.

MANILA HEMP it is obtained in the Philippines from the leat-stalk which form the apparent trunk of a tree (. Masa kextilis.

of the banana family. This tree is like the common bananat tree except that the leares are a litte narrower and it dees not procluce edible fruit. To obtain the fiber the tree is cut down, the beares removed and the leat-stalks separated, and scraped with a dull knife till all of the pulpy part is cleaned off. The coarse fibers which remain are then washed, dried, and made "IF" into bales. They are longer than any other commercial fibers, and the rope and twine made from them do not harden mor stiffen when wet. The natives of the Philippines use the finest filers in making "abaca" cloth. 
Sisal hemp, or henequen comes chiefly from Vucatan, SISAL HEMP where it is the principal aticle of export. It is cultioated in other parts uf Mexion, in Central America, the West lndies, and, to a small extent, dsowhere. It is obtained from the fleshy

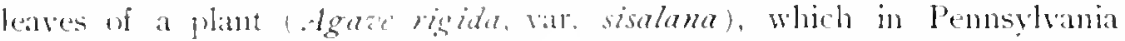
would le called a "Century l'lant." The filer is obtained by cutting the leaves and sclidping the fleshy part away with a large wooden knife, or otherwise cleaning it by minhery. These fibers are stiffer and less strong and mot so long as these of Manila hemp, but are much used for making rope and twine, in the manufacture of sacking for cotton, and in making brushes.

The Agave plant or Naguer, in this country THE AGAVE PLANT popularly called the "Century Plant," is a native whexion, where there are many species. It is, perhaps, the most useful plant which grows in that country. Sisal hemp (see above) is one of its products. There are other important fibers produced ly andue plants, such as Tampico hemp, sea grass, maguey, ixtle, lechuguilla, piti, and yaxci. Some of these are exported and all of them are used locally to make articles of all kinds, such as mats, bags, ropes, harness, hammocks, hats, haskets, brushes, etc. In their native home, agave plants reach maturity and flower at an age of three to fifteen years according to their species. The flower stalk, coming out of the centre of the plant, often reaches a height of thirty feet.

There is one variety of agave plant which is cultivated in Mexico for its sap, from which a chrink, "pulqué." is made. When the plant is ready to) Llowm, the central bud is cut out, keaving a cavity holding a couple of gallons. Into this the sweet sap exucles, and is removerl twice a day, being sucked into a long narrow gourd and emptied into a goat-skin bag. It is then mixed with milk and a little rennet, in a vat of raw oxhide, where it ferments rapidly and forms an intoxicating drink. "Mezcal," a stronger alcoholic drink, is distilled from the fermented juice of another kind of maguey plant. Agave plants furnish many articles of minor use to the natives of Mexico, such as building material and razor strops from the flower stalks, soap substitute from the roots, and natural needle and thread from the leaves.

NEW ZEALAND FLAX

New Zealand flax, another excellent rope fiber, comes chiefly from New Zealand. It is obtained by scraping awa the pulpy part from the long nurum leaves of a plant of the lily family ( Phorminm lena. $)$. Other similar fibers are Matritius hemp, (Furcaca gigantea), bowstring hemp (Sanse-

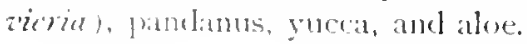

Pincepple fibers are obtained by scraping away the PINEAPPLE FIBER fleshy parts liom the leaves of plants of the common

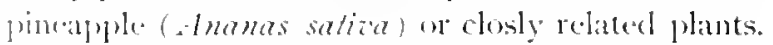
These fibers are hon and shorter than those from agave plants and are much used by the Filipine for making a fine cloth called "piña." In China, Mexico, Sonth Anerica, and in parts of Atrica, pineapple filers are much 


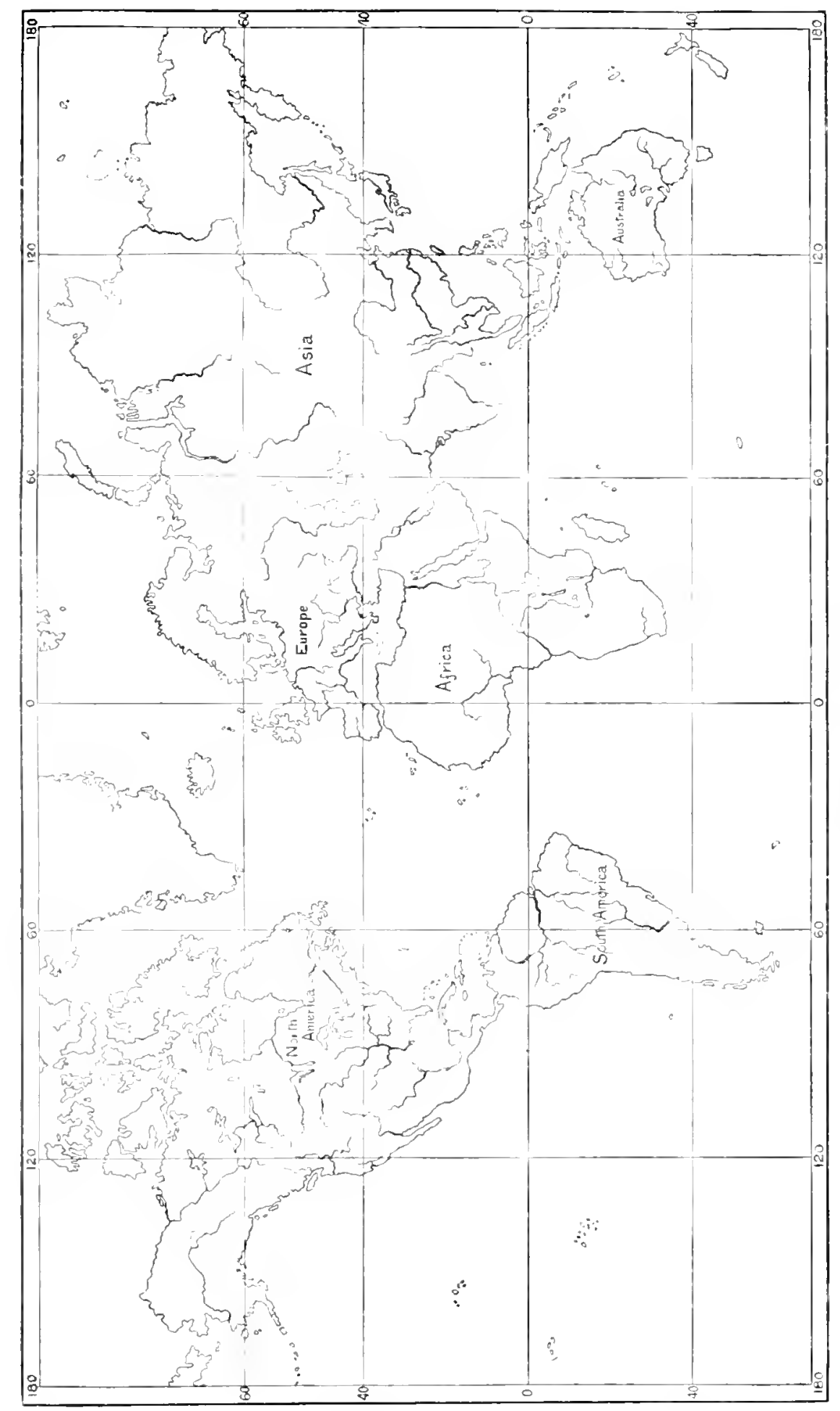



used for making cloths, ropes, ete. Throughout Wexicu, Central and houth America, fibers from plants mearly related to the pinedplete (Fromelia species) are used. These fibers are not of very great impurtance in the world's commerce.

Raphia fiber from Madagascar is used principally ly gardeners

RAPHIA for tying plants. It comsists of strips if skin peederl hy hand from the surface of the leaflets of a palm tree Kuphid fodunculata). It is used for making mats amel lasketry, and hy the natives in weaving cloth. A similar raphia palm yiekds a filser used locally in west Africa.

Piassaba or lass is a course stiff filer used for making broms

PIASSABa and brushes. It comes in lengths up to four leet am in diamęter from one thirtieth to che sixteenth of an inch. The commercial varieties are known as West African and Brazilian Balia and Para) bass. They are obtained from the fitums sheaths which grow around the leaf stalks of certain palm trees. The 11 est African bass comes from the tree (Raphia rimifora) which yields the leai fiber referred to alove. The sap of this tree is used by the natives in making wine. The Bahia piassaba (or piassava) comes from a different palm (. Attaled funifera), and the Pará bass from another (Lecpoldinia piaseabe).

Somewhat finer brush fibers are obtained from the leaf sheaths of other palm trees, such as kittool (Carrota urens), Palmyra fiber or hassine (Borassus flabellifer), Chinese coir, (to. These last-mentioned fibers come chiefly from Ceylon, India, and China.

Saw palmetto is used for making brusles, and for

SAW PALMETTO mixing in plaster, as well als for praper stock. It is obtained in our suthrom states from the leaf stalks and the creeping stems, commonly called the routs, of the saw palmetto palm (Serenod semalate). This plant is rich in tannin and is an important source of tanning extracts. The fiber is the spent material from which the tannin has been extracted. This palmetto grows wild in the Gulf States and its leaves are utilized in making the artificial palms commonly used for decorations.

Bast fibers occur in many plants, in a layer undermeath

BAST FIBERS the outer hark. In small plants like flax, they are fine in texture and serve (1) strengthen the stalk, while in trees like the linden they are coarse.

Flax ranks next te whion as a useful filer. It is the bast fiber of

FLAX an herb (Limum usitatissimum) which crows to a height of about two and a half to three fret. Russia profluces more than me half of the world's supply of flax, lont that irom bedegum is the lest guality. Italy, France, Holland. Iretand, and Esypt are the other important producers. A little tax fiber is erown in Michigan, Winnesenta, and the l'uget

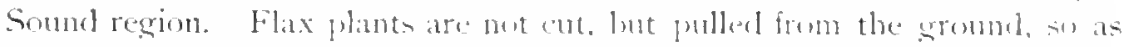
to geet the longest pusithe tibers. The secels are then remowed ly aripplinge" or drawing thromgh the torth of an irom comb, and the stalks 
"retted." "Retting " is merely a prexenson slow and partial decaly, which is carried on ly solking the stalks in water. wither in a pool or slowly rumning stream, or by layng thom on hamp meatoms exposed to the rain and dew. The filur remeins undfiected while the other parts of the plant are softened ly this treatment. The stalks atter "retting" are "hroken" by punding and then "seutched" or scraped with a broad wooken knife till all of the woxly protion is removed. It is then "lnackled," or combed, to separate the long filues, or "line," irom the short fibers, or "tow," and the fong flute are prepared for spinning. Mest of this work is clone by hand in preparing the best prates of flax. Twines, cantas, linens, and laces are make of fax. 1t is lleated by exposure to the sun, and by treatment with a dilute whtion of chloride of lime. Flax. expecially in the form of linen rags, is used in paper-making.

Flax plante which srow till the seeds are fully ripe yield fiber of poor quality, hut the seeds are then richer in wil: the srowing of flax for seeds is, therefore, a separate industry. The seeds are grown extensively in Russia, India. Argentina, and the Lnited States.

Linsed oil is made ly arushing flax seeds and then pressing

LINSEED OIL them in a machine. When the seeds are heated and pressed, more uil is ubtained; but "cold clrawn" oil is of better quality. Linsecel sil-cake romains after the oil is extracted from the seeds, and is a valuable cattle food. On trying, linseed oil forms a varnishlike substance. This property makes it useful in paints and varnishes. Boiled linseerl oil is prepared by heating the raw oil and adding to it certain substance which cause it to dry more rapidly. After much boiling it hecomes thick and is the hasis for printer's ink. Linoleum is made of linseed oil mixed with ground cork and gums. The oil is sometimes vulcanized he heating with sulphur, wiving a substance much like rubber.

Flax seeds are used in making pentices.

Hemy, is a fiber used extensively for making twine and rope.

HEMP True hemp, is the hast fiber of a plant (Cannabis satiza) which grows to a leight of six to ten feet, with stems as thick as a man's finger. Russia produces more hemp filier than all the rest of the world, lnt the plant is cultivated throughout the warm parts of Asia, in Italy, France, Hungary, Germany, and Algeria, and in Kentucky, Missumi. lllinois, and California. The fiber is extracted by retting, cleaning, and combing in much the same way as flax, except that more of the work is done by manery. As in thax, the long combed fiber is called the "line," anel the shurt strands "tow." The commercial filner is much longer and coarser than hax, Int not so strong, and camot be bleached perfectly white; it is therefore unsulalile for weaving into fine fabrics. Hemp is known on the market from its country of origin, as Russian hemp, the strongest; ltalian hemp, the finest: Kentucky hemp, etc. Many other fibers coming from flants which are botanically different, are called by such names as Sisal hemp, Tampicu hemp, Manila hemp, Mauritius hemp, sumn hemp, bowstring liemp, etc. 


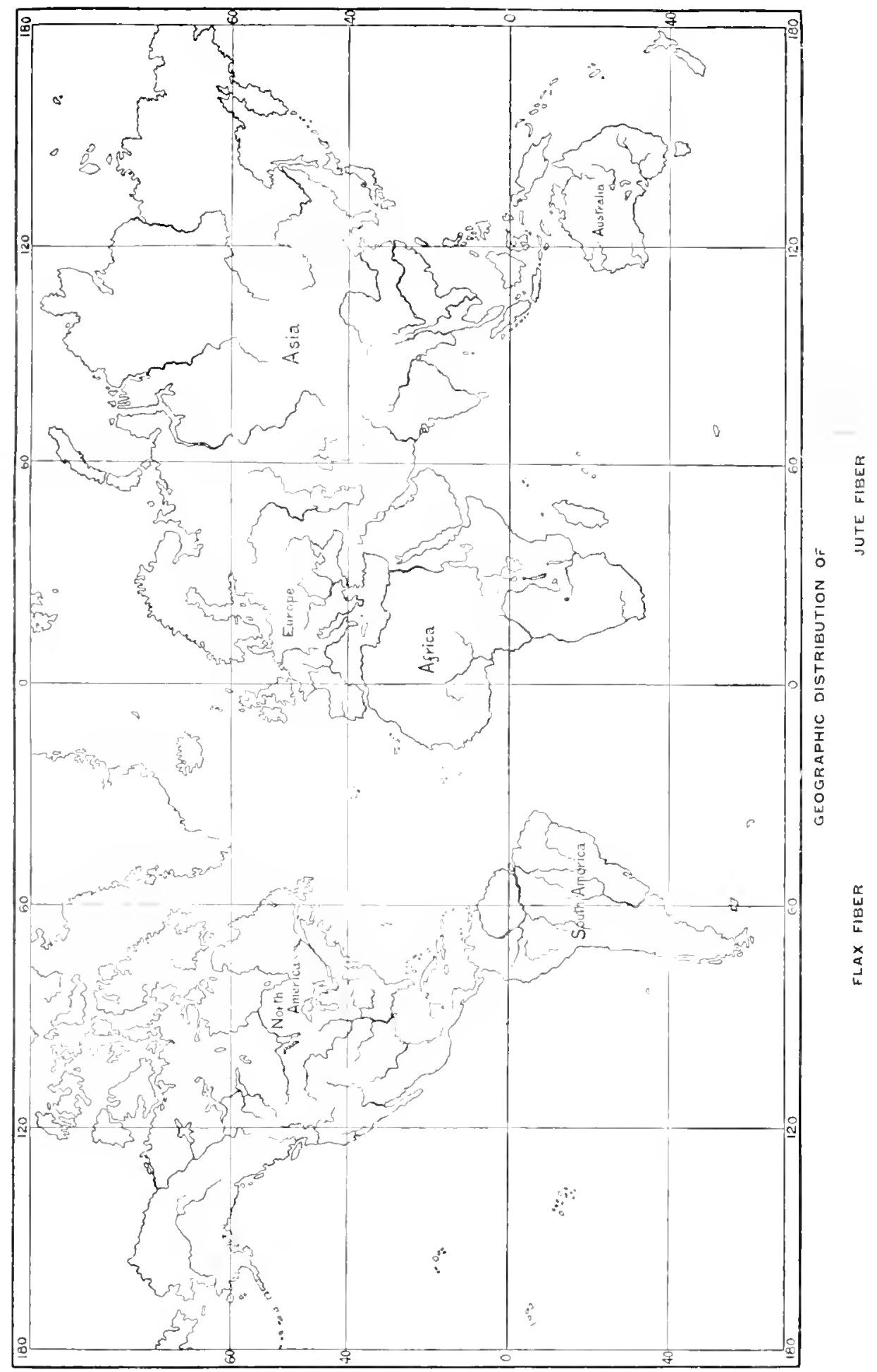



Hemp seeds are pressed like flax secels and yed lump oit. which is similar in nature to linseed oil and is used in soap-making and in puint. An extract from the leaves is used as an intoxicant (hasheesh) in Aral hia.

Jute cones almost entirely from the province of Bengal. Inclia. It

JUTE is the bast fiber of plants (Corhorus species) which srow in tall slender stalks like hemp. It is separated from the stalk like hemp, by retting and cleaning. The fiber is long and lustrous, soft, and easy to spin into coarse threads. It is much weaker than hemp, difficult tn spin into fine threads, does not bleach well, and loses in strength when expused to dampness. It is used for making burlap and gumy cloths, twines and ropes, as well as in carpets, curtains, and upholstery fabrics, such as plushes.

Jute butts are the short ends of the stalks and the rough JUTE BUTTS fibers rejected in preparing jute. 'They are very important paper stock, being imported in lare amount.

Ramie or China grass is a fiber of increasing importance. It grows in southeastern Asia and is cultivated in small amounts in Mediterranean countries and other parts of the worid. The plant (Bochmeria

RAMIE niza) belongs to the nettle family and grows in tall slender stalks like hemp. The bast fiber is difficult to separate from the lark, owing to the presence of a gummy substance insoluble in water. It has been used for a long time in China, where it is prepared in a slow and imperfect way. Improvements in machinery and in the chemical process of cleaning the fiber are making it possible to utilize it in Europe and America. The clean fiber is fine and silky; its strength is three times that of Russian hemp. and its weight only a little over half that of linen. It is a very valuable cordage fiber, and is extensively used in China for making " wrass cloth." In Europe it is made into fabrics, some of which closely resemble silk, into underwear, velvets, and various cloths. It will come into more general use when cheaper methods of cleaning it are derised.

Bast fibers from other plants are extracted and used in

BAST FIBER various parts of the world: hut few of these are of any general importance. Sunn hemp) (Crotalaria juncea) is grown in India. The common European linden or lime tree has a bast which is easily stripped off and is employed by peasants for making ropes, mats, bags, hats. etc. The American linen or lass wood tree contains a fiber of the same kind. A beautiful material called Cuba bast is obtained in shects irom a tree (Hibiscus clatus) in the West Indies. 1t is used like braid in making hats and for tying bundles of cigars. lace bark is the bast of another Wrest Indian tree (Lagetta lintearia). The paper nuberry tree (Broussonettia papyrifora) furnishes a last used in paper making and, by ratives in Oceania, for making bark cloth ("tily ").

The cocoanut paln is, in the countries where it grows,

THE COCOANUT one of the most useful plants, in fact in many islands PALM it is looked upen an the one thing necessary to exist

ence. Coconnut palum ( Cocos nucifera) grow in the coast regions of all tropical commeries, frecpuently reaching a height of a 


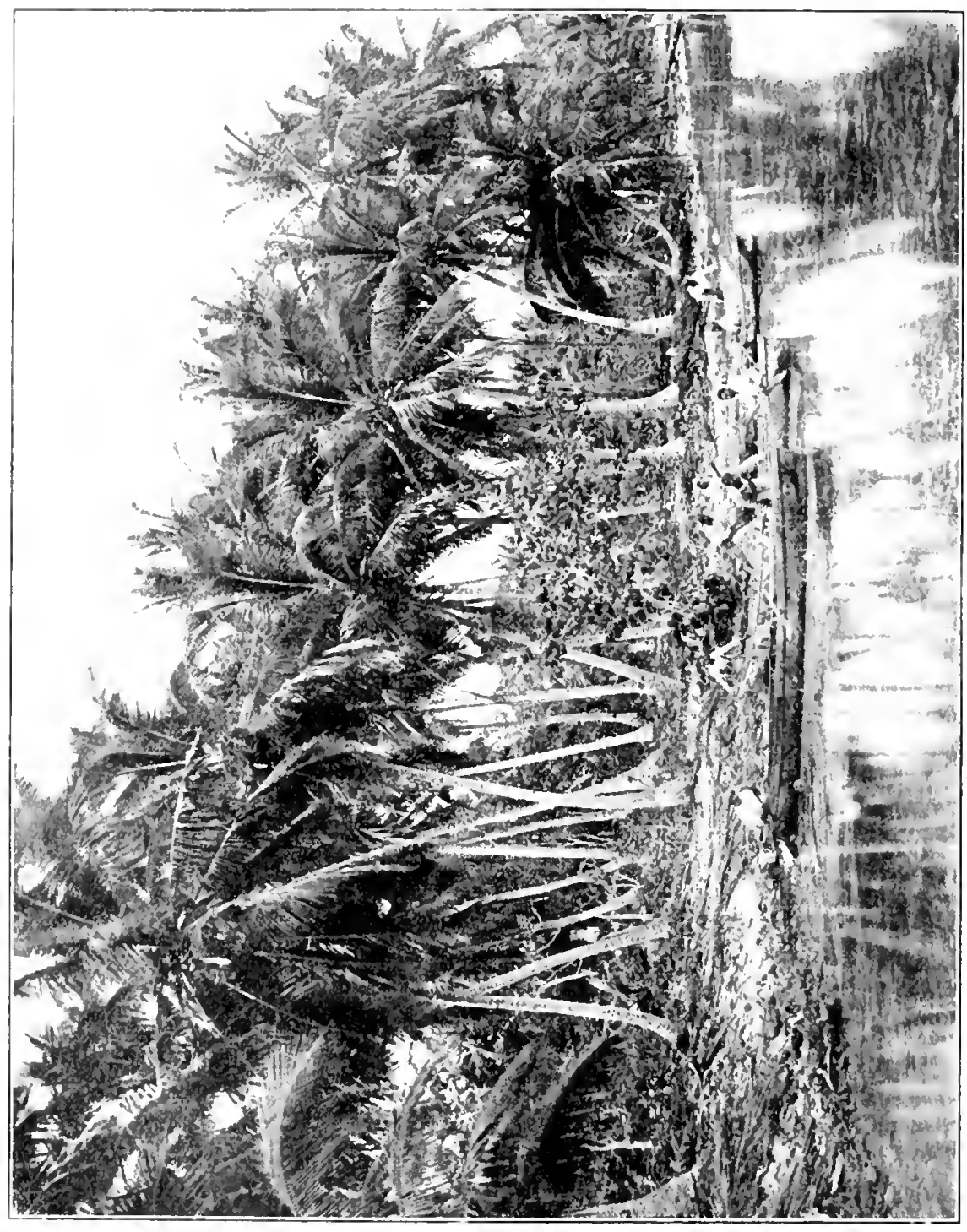





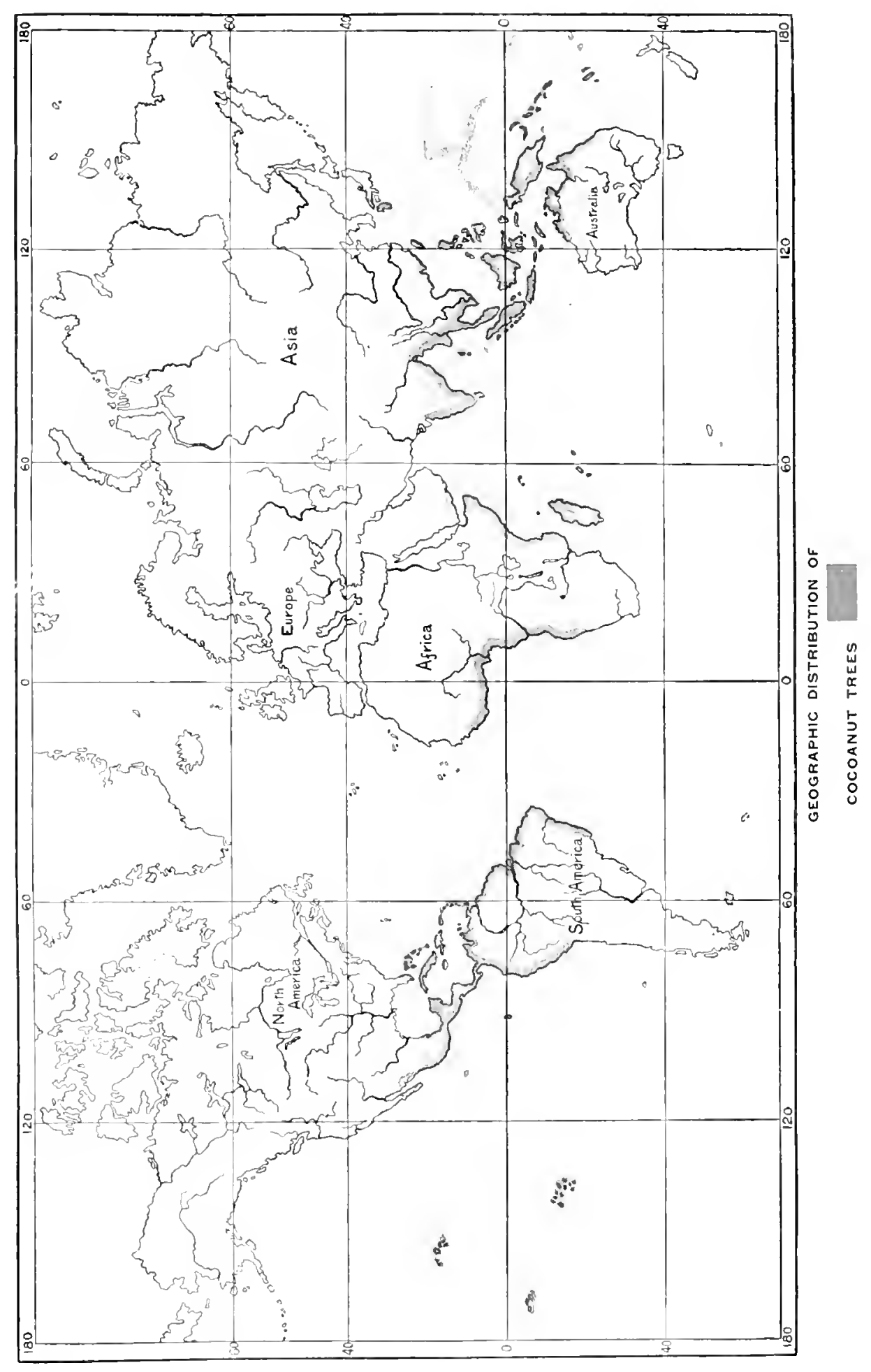


hundred feet, with a crown of twenty ur more teathery leates, each twelle or fifteen feet long. The fruits, coesanuts, are produced from the time the tree is five or six years old, sometimes for sixty or more years. A tree in full bearing will ripen from eighty to two hundred nuts a year. Each nut is enchesed in a thick fibrous husk. The unripe nut is lined with a soft relille. albumen-like jelly, within which are one or two pints of a clest liquiel, which is refreshing and nourishing. When the nut ripens, the allumen or kernel hardens and is used for foucl. It is often grated, dried, and sold its desiccated cocoamut. Fresh corounuts atre imported intor the lenited tiates from the West Indies, Central America, and Codombia, anel are grom in Florida and California.

The ripe kernels when dried in the sun are called "copral" and are. pressed to olstain cocoanut oil. Copra is one of the principal exports from the istands of the Pacific and from other places where the tree is common.

Cecoanut ail is used throughout southern and south-

COCOANUT OIL eastern Aslit and the adjacent islands als a cooking and illuminating (ill, as well as for anointing the budy, and for minor purposes. For lighting, the nativen put it into a smatl dish or open resset and dip in it a piece of cotton on loosely twisted fitere one enel of which extends over the edge of the dish and is lighted. In Europe and America it is used for making soap and candles and for cooking. Cocosmut wil is lingtiel at temperatures above $65^{\circ} \mathrm{F}$. betem this it is a white solied, much like lam in appearance. In Ceykn and other hot comtries it can le pressed from coeoanut kernels without the aid of artificial heat, but in temeperate climates copra must be heated when the ait is extracted. The copra is pressed either in crute native mills or else in pwerful machines, which squeere out the oil, leaving behind cormant oil cake, useful for cattle foud.

Coconnut shells are made into cups, latles, and other utensils hy natives. The trunk of the old cocoanut tree furnishes woul which is used for homsebuileling, for abinet work, towl handles, and wher articles, and is known in commeree ats poreupine woml. The bark is uset for taming, the roots for medicine, the tender terminal bud is lofited and eaten as a vegretable, and the leates are used for thatching, for making fans, mats, and baskets. The lest sheaths are fibrous and are used by the natives like cloth, and by florists for ornamert. The sap obtaned by anting a sash in the flower but, when

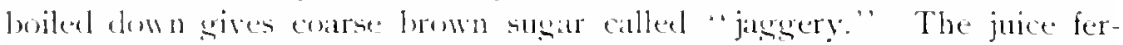
ments raphelly, forming "texlely" or "tuba," an intexicating patm wine, which can be converted into vinegar. "Arrack" is a stronger liquor distillecl from toldy:

Cucounut filee or onir is obtained from the thick

COCOANUT FIBER outer husk of the nut. The husks, after removal, are suaked in water till sufficiently softened, and then the fibers are separated from each other, combed, and cleaned. Commerecial coir fibers are rather coarse, stiff, amel very dastic brown filaments. The lest gracles are straight, and up to ten inches long. The stiffest are used for making brushes; the longest and stritghtest for ropes of all sizes. 
coarse thread, and crova matting: and the shorter curly hibers for stuffing. Coir ropes are valued because they are strong, wastic, and not affected by salt water.
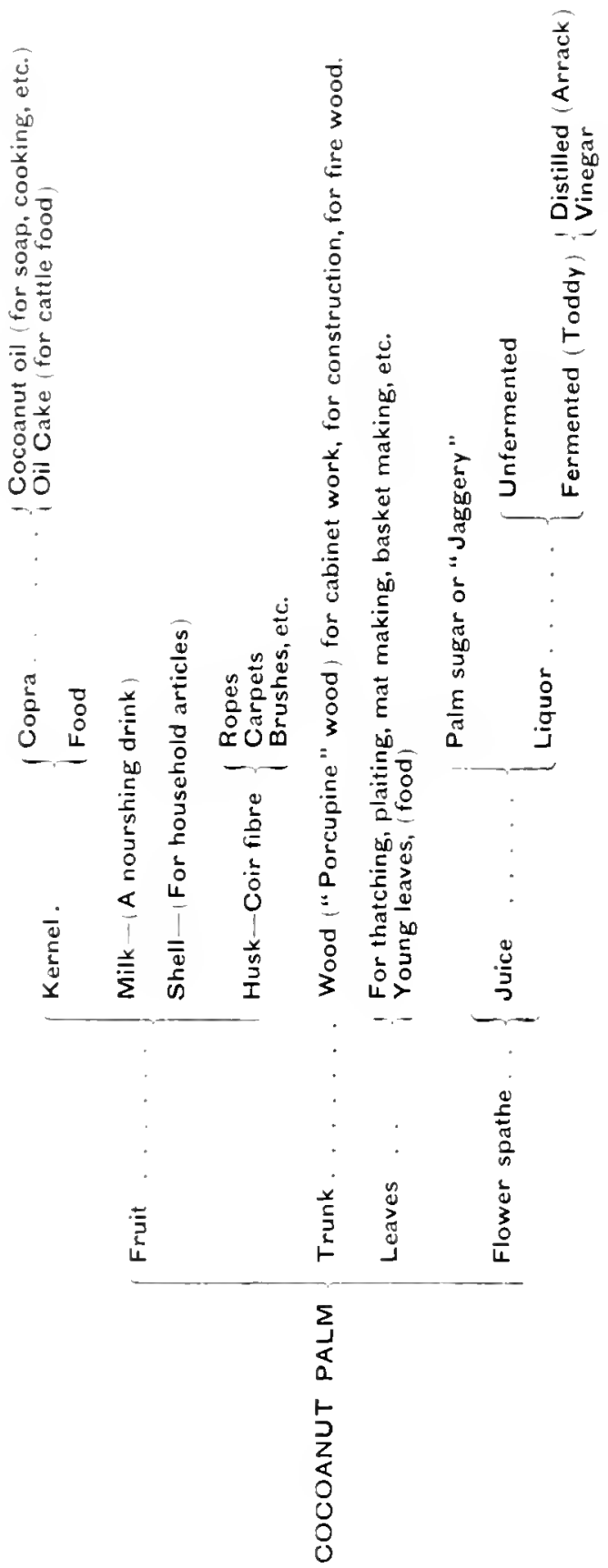



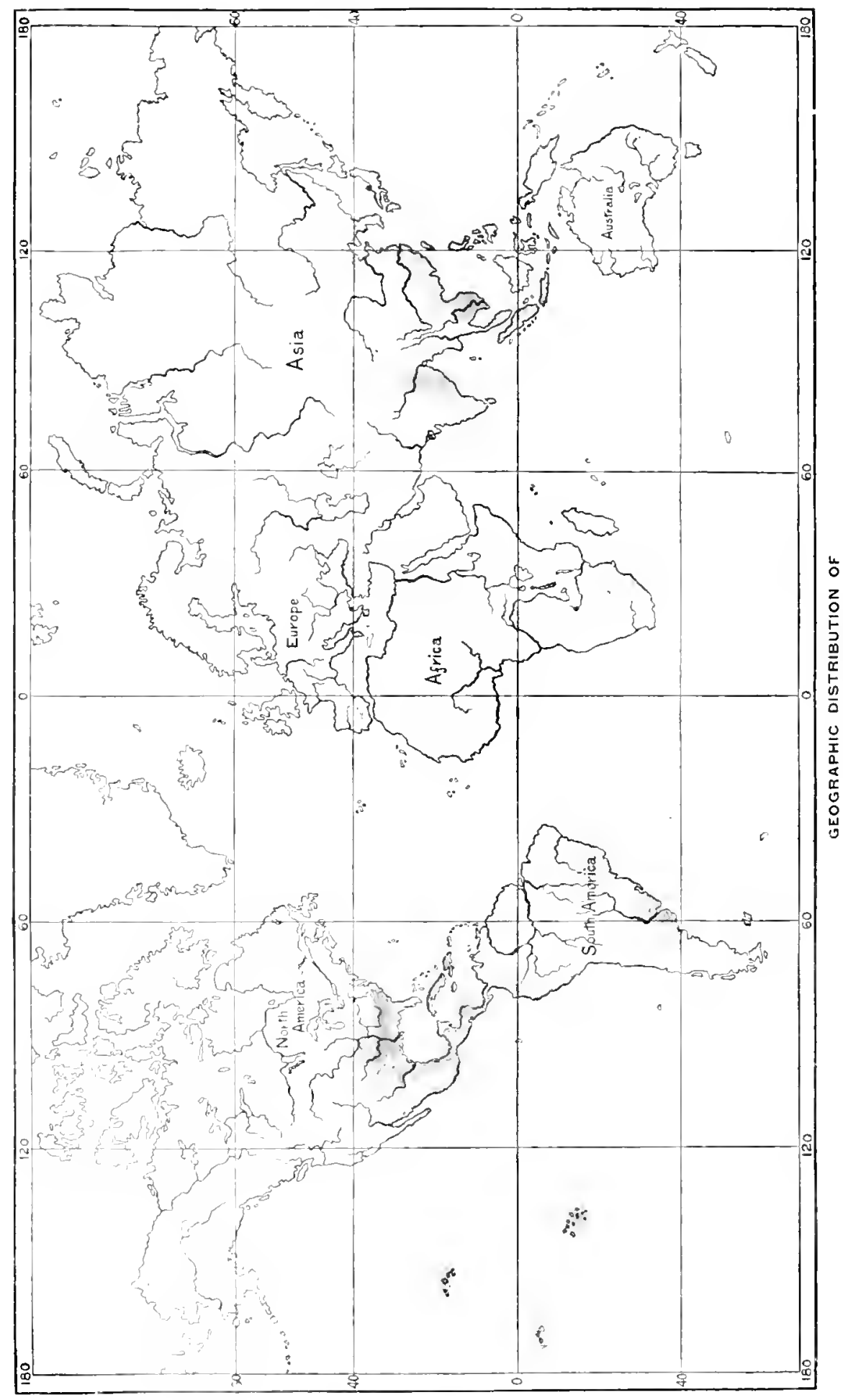




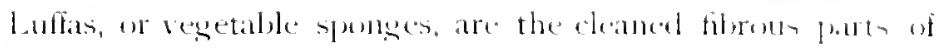

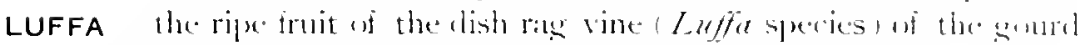
family: They are eyported from Jayman.

Gakum is prepared from the short waste fileres abtained ly pirking (n) pieces rold cordage. It is treated with taus to make it flexible and is used to caulk the seams of vesseds. Whell specially prepareel to make

OAKUM it antiseptir, it is employed in surery for clresing wommels.

Cotum. the most important vegetahle filner. comsints uf the

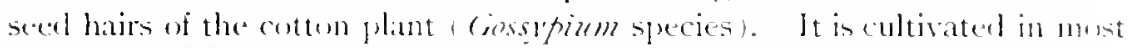
tropioal and subtropical renutries, and has been nsed since the most ancient

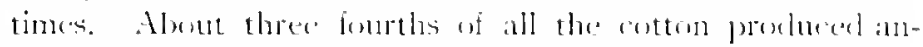

COTTON mually is grown in the sonth Atlantio and Gulf states of the Lnited States. India, Egyn, China, Braxil, and Aciatic Russia ale important polucers.

The individual cotten fiber is a single, (e) longated, flat, twisted cell, which

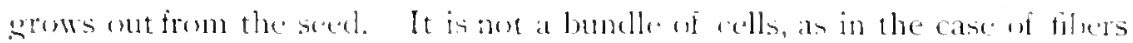

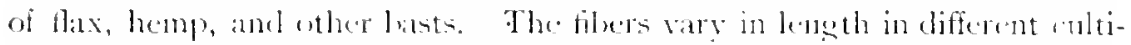

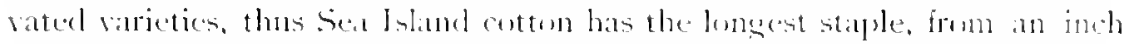

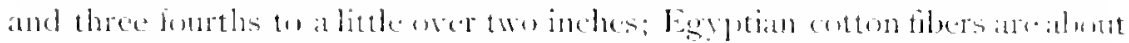

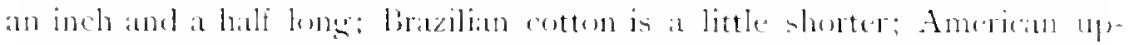

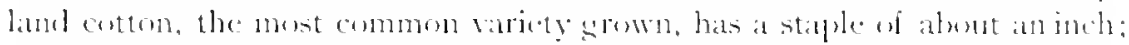

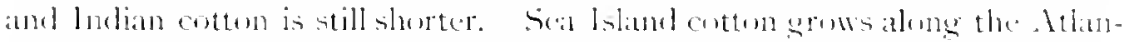

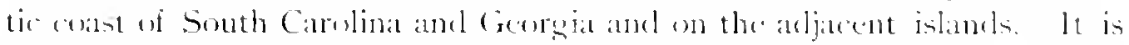

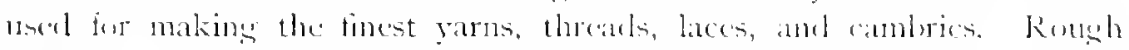
Pertivian cotton clonely resembles wont and is used for miving in wosten

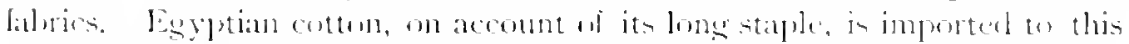

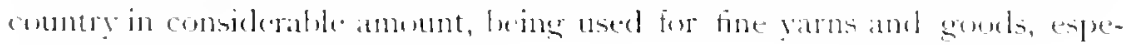
clially in hosiery and mulcrwear.

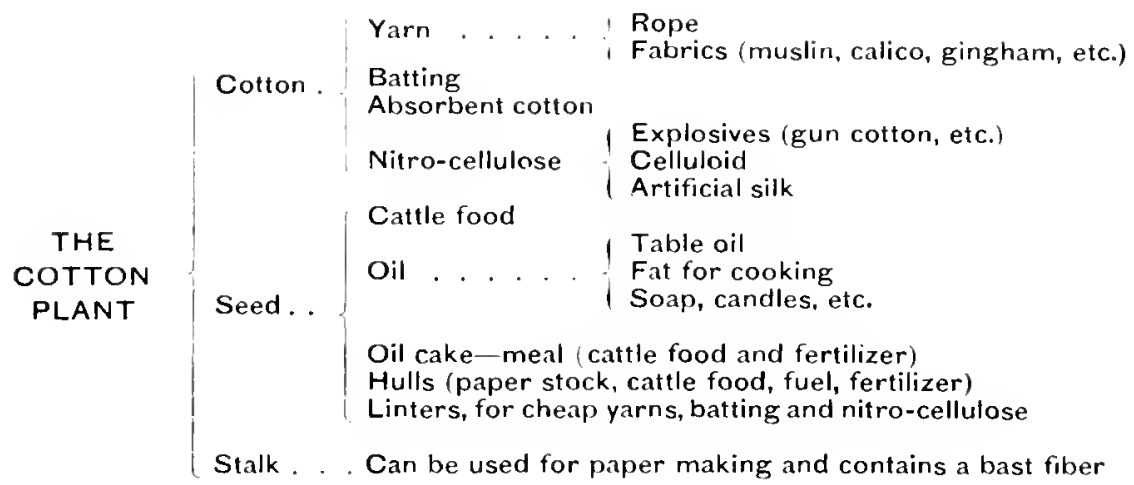

The cotton phant usually whens tw a height of only two to four feet. but in places free from forst some varieties swow fifteen feet high. After coton is picked from the bolls ly hand, it is ginned, or freed from the seeds. In 


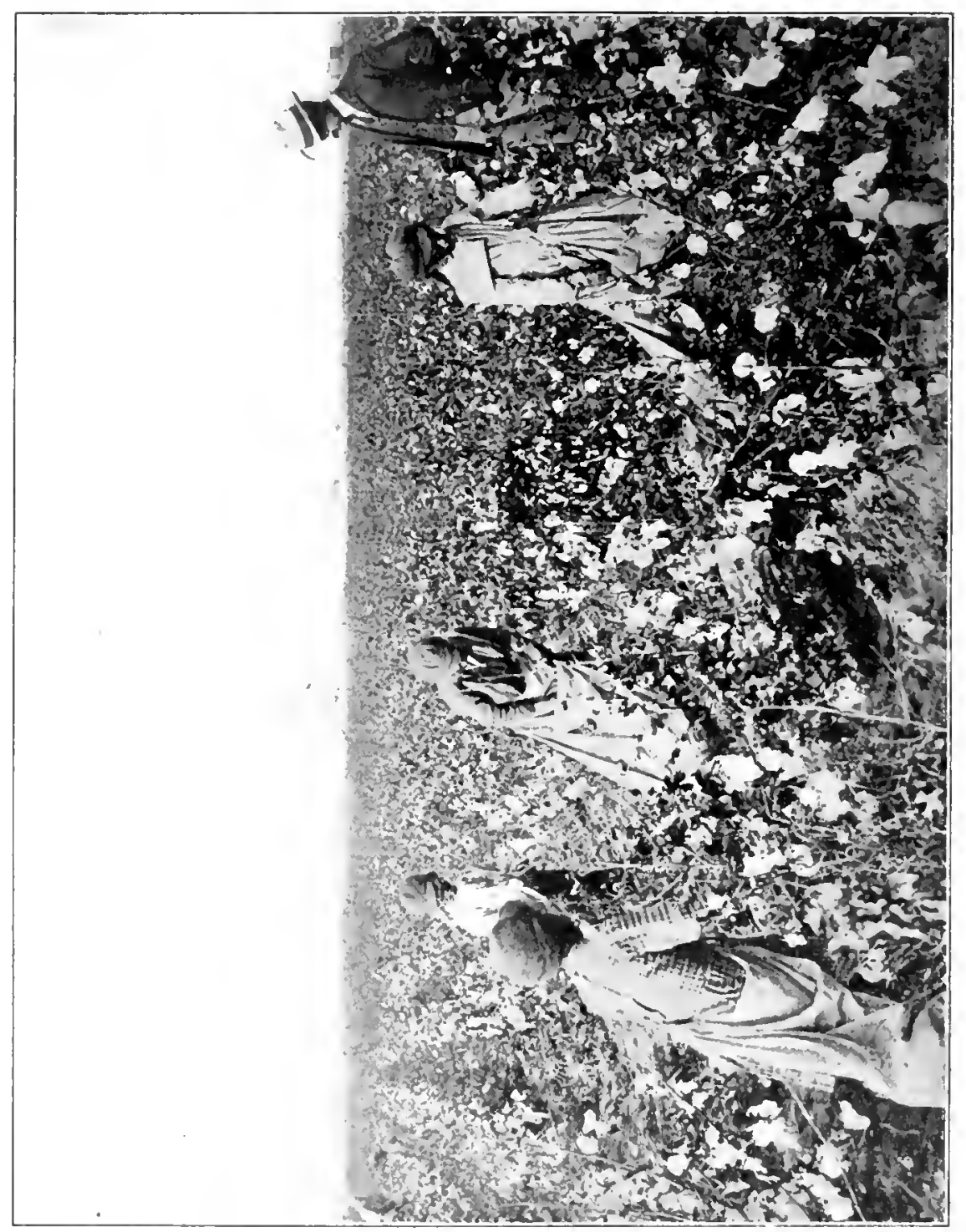


a cottongin, seed cotton is held in a box with a grating at one siele. Through this grating project a number of steel discs, motched on the elges and called saws. When the saw's rotate, the fiber catches in the terth and is pulled away from the seeds. The fiber is blown from the saws through pipes, to a cotton press, where it is baled. Raw cotton in bales is shipped from the gins and market towns to the cotton mills. Liverpool, the largest foreign cotton market, practically sets the price for cotton the world over. The greatest centers of cotton manutacture are located in Lancashire, England; the New England states, the Carolinas, and Georgia. Germany, Russia, India, Japan, France, and other European countries are also important cotton consumers.

Within the past one hundred and twenty years the manufacture of cotton has progressed from the condition where the work was done almost entirely by hand, to the present state, where it is better done by perfected machinery. In a mill, the cotton hales are openal by a machine, and the fibers pulled apart and spread out. In various other machines, they are picked and cleaned from all dirt and leaves, and carded by passing through rollers covered with steel wire points, which comb the fibers so that they lie" parallel. The fibers are first loosely twisted into a "roving." which is wound on spools and from these is spm by a "mule jemny" into yarn on thread. Yarns are woven in power looms into clotlss of different kinds and qualities, such as muslin, silesia, cheesecloth, cambric, duck, canton flannet, India linon, etc. Calico is made by jorinting designs on plain cotton gordh. Gingham is woven of cotton threads of different colors. Cotton threads are fredpently woven with threads of silk or woul inter mixed seonls. When cotton is "mercerized" (treated with a solution of caustir sodat the fibers shrink somewhat, hecome stronger, are casier to dye, and afcuire a silky luster. This treatment is applied trocetton either in the yarn or choth, usually the former, and results in heautiful glossy fabrics. ()ther fibers, such as flax, are sometimes mercerized. Cotton fabrics are often stiffened and given "body" hy starch, dextrine, or sum arathic.

When cotton is ginned, many short fibers remain attathed to the seeds. These, down to the rery shortest, are remened hy special gins and constitute "linters," which are used for mixing with other cotten in spinning cheap yarns, and for making into watding.

Cotton serels, atter the fiber is cleaned from them by

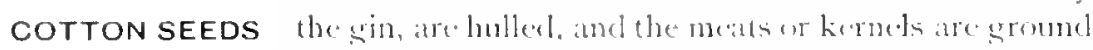

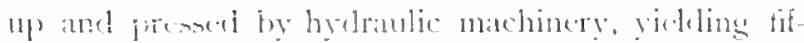

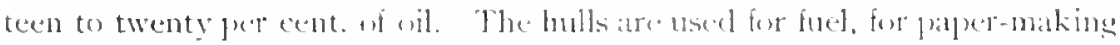
and for feeding stock. The wil is puritied by the atelition of at smath amome of alkali, ustally austic protash, anul is useel for forot and her conking, at a

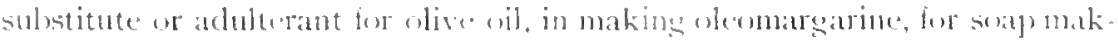

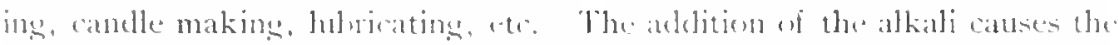

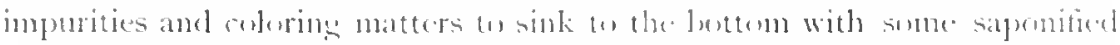

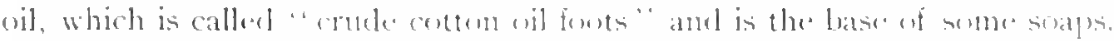
After the oil is pressed from conten-secel ketnels, the remainime material hats 
the furm of hard slects less than an ind thick, called oil-cake or press-cake. These are ground up inte meal, wheh is used for feeding cattle, and ats a fortilizer. The cotun secels themselves are used in large amounts for cattle fiunl. The comparatively recent derelepment of the cotton oil industry has

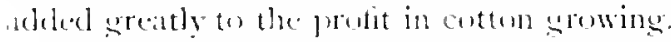

A small insect, the loll weeril, has caused great clamage to growing cottom in Mexico, Texas, and the southwest. It lays itseges in the young buds amel lulls, and the larve cat and destroy the cotten Many methods are heing tried to destroy this insect or prevent its ravages.

Silk cotton or regetalle silk consists of the hairs from

SILK COTTON seerl porls of various trees and plants. The most common commercial silk cotton is "Kapek" from the pods

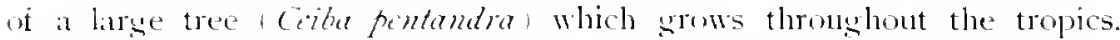
Jara furnishes most of this fiber which is on the market. It is used for stuffing fillows and in upholstery Similar fibers are ohtained from other trees

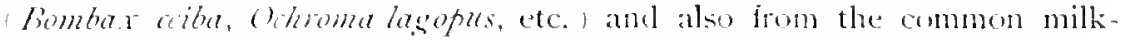
weel. Silk cotton sliffers from true cotton in that, its cells are thinwalled, stright and smouth, while those of true cotton are thick-walled, hatre curded cdges, and are twisted many times throughout their length. These twists cause ane fiber to interleck with another in spinning. Becanse of the smoothness and straightness, silk cotton cannot be spun.

Paper can be made from almest any kind of filorus material. The

PAPER stucks principally used are the wouls of certain tress, a few kinds of bark, the prorest pualities of such filets as cotton, Hax and jute (inclueling the waste from mills which use the we filers), cotton and linen rags, worn-out ropes, hambou, and straws of wheat, rice, esparto, w other grasses. The inest papers are macle from linen rags, but all of the cheap grades are makle of wool. In this country three quarters of all wond pulp is made of spruce, and about one eirhth of poplar wool. Nissachusetts, New York, Maine, Wisconsin, and Pennsylymia are the most important paper-making states. The chief falper-making countries are the Lnited States, England, Gemany, France, Austria, ansl Jelgium. In making paper, the material useel is cut into small pieces and cleaned by washing, bleaching, and chemical treatment, from the comenting and coloring materials which may be combined with the fibrum part. The pulp obtained consists of the more or less pure fiber (cellulose) and may be bleached perfectly white or dyed any alesired color. The cheapest grades of wood pulp are made by grinding the wom, but in these the fibers are broken short, and they are used only in how arake prapers. The pulp is fed antomatically on a moring belt made of wire chth and usually has added to it "sizing" in the form of hard resin. The soft shect of pulp is then pressed between felt rolls, dried, and passed through a series of hated metal mollers, which compact the tibers and give the paper

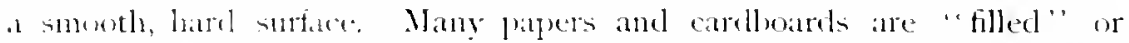
"kneked," that in, they hate kadin, talc, or some other powelered mineral

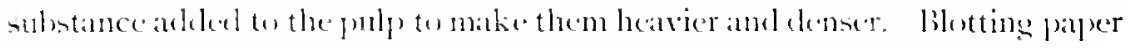
has no sizing added to it and is non "alendered" ly the heary rollers. 


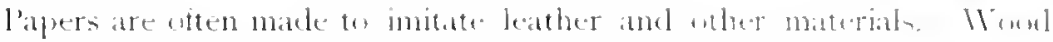

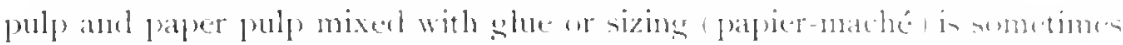

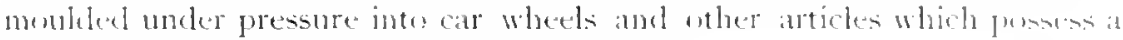
surprising amount of streneth and durability.

Artificial silk is make from very pure paper stock.

ARTIFICIAL SILK Cellulone prefrared from wood or cottom is treated with nitric acil, forning what is called nitro-cellulow. This is then dissolved in a mixture of ether and alcohol. This solution is atriven

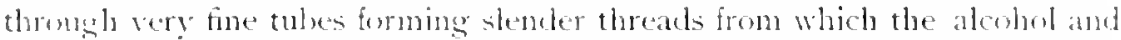
wher eraporate away at once, beaving the nitro-celhulose as a fine lustrus fiber. Subserfuent treatment with anmonimm sulphide or other agrent de-nitrifies it ant renders it lesin inflummable.

Cwlubidts is a substance artificially prepared from celluluse.

CELLULOID The fure celluke simikar to that used in making artificial silk is acted on by a mixture of uitric and sulphuric acids, heing converted into nitro-cellulse. This is thoroughly mised with melted camphor, by grinding in heated rollers. It clissulves in the camplors, form-

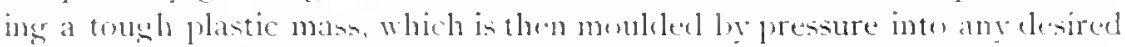
form. It is made in sheets by planilug oll from solid blocks in a machine similar to a seneering machinte. Cellubid is male in many colors and is used as a substitute for hard rulder, tortoline well, and irory, for knite haudles,

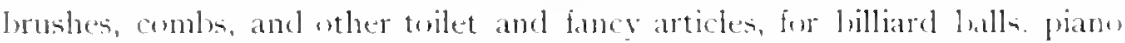
keys. collars and cuffs, and articles of jewselry imitating coral and jet.

Straws, the stems of grains or other grasses, or of reeds on

STRAwS rushes, are used for hat making, lasketry, mattings, chair seats, broons, thatching, mpes, and in paper-making. The conmonest are those from rae, wheat, harler, rice, esparto, brom corn, rushes and reeds. Twigs of willow and ronts are also used for basketry.

Spanish mons srows from South Carolina to Argentina,

SPANISH MOSS hanging in flense masies from the liranches of trees.

The onter cuticle is removed from the plant Tillandsia usmeoides by machinery and the remaining fiber, which resembles horse hair, is uned for upholstery. The unprepared moss is used as a parking material for fruit and glass.

Zacaton, Mexicun whisk, or lroom root, is the root of a large

ZACATON grass Eficumpesmacrowa) which grows in the conl districts of Nexico. It is used in making lorushes.

Crin Vegetal is the shrededed leaves of a small palm (Chamacrops humilis., to is imported from Algeria in the formof ropes, and when operued up is used in upholstery.

Panama Straw, used in making l'anama hats, is the split leaf of a palm tree (Carludoica palmata).

Rattan comes from the Fist Indies. It is the stem of clinls.

RATTAN ing palms (Calamses sperien). These palms are sometimes many hundred feet in le-1ugh and usually have strong homed

-.' Celluloid is a trade name registered by the cellulid co. 
spines on the stems and lates. Rattan owes its value to its strength, its Hexibility, and its uniform size. In Asia it is used to an chormous extent for lasketry and ropes. It is imported for use in making furniture, baskets, canes, whips, etc. In preparing rattan "cane" for market, the natives clean off the leaves and outer cuticle by pulling the stems through a motch in a tree or board. After this dressing, rattan is cut into lengths and tice in bundles for sale. The smooth "bark" of rattan is split of by machinery in long stencler strips and is used in chair-caning. Peeled rattan is used for stiff hrushes, and for basketry.

Bamboo is the largest plant of the grass fanily (Bambusa

BAMBOo species). It is found in tropical countries, but is most common in Japan, China, India, and the East Indies. Its stem sometimes reaches a font in diameter and its height is occasionally a hundred feet. In its native comtries it is used for house huilding and all sorts of construction pupmses, for making furniture, agricultural implements, canes, fishing reds, and innumerable other things. In China, bamlem is used in papermaking. The soft tender shouts just appearing above gromol are sometimes cooked and eaten in bott Japan and China.

Bambon splits readily into long flexible strips, which are woven into basketry of all kinds and used for making stift bruslies.

\section{WOODS.}

Lumber is the product of the sawmill after the trees of the forest have been out into logs and hatuled to the mill on wagon, rail or river. Beams, scantling, rough boards ancl lath are used in framing, sheathing and rougl construction, or they are sent to the planing mill and there surfaced. edgeal and dimensioned for exterior and interior finishing and higher grade construction. Rough and surfaced humber also go no special mills and are mantiactured into finished articles. such as huilding materiat, furniture,

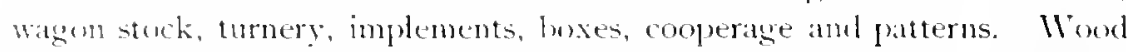
in used in the lug for posts, telegraph poles, railway ties, sills and bridging timber: ur is split intushingles and fencins. The consumption of wood for fuel throughent every forested comntry of the werlel is enormous, and the extration if tar, gnms, resins, tans and dyes from word and lark, constitutes injurtant industries. The weods of cone-bearing on neelle-leaf trees are eften called " softwomels," while these of the broad-leaf trees are classed is "hathlwals." These are not, however, properly elistinguishing terms,

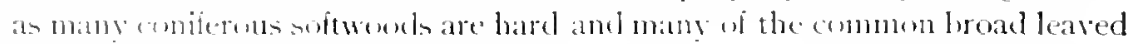
wexdoare nearly ats soft as white pine.

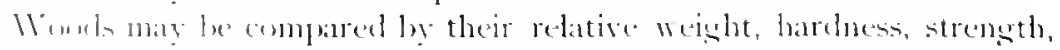
dasticity ambl lumblility, and ly coler and grain. Vellow, loww and red are

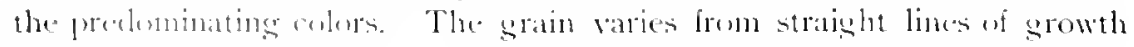

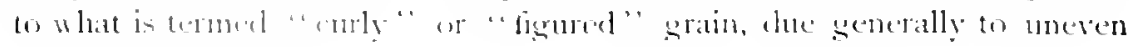
(1) twisted arowth.

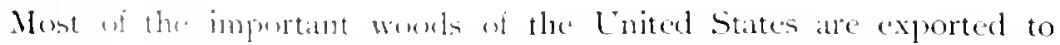

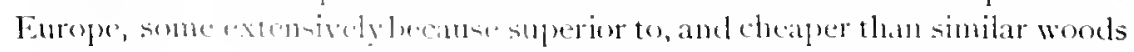


of that region. Many of the wends of the Pacific coutst are also expurtorl to Jajum, Chima and the islands of the l'acitic.

\section{NEEDLE LEAF WOODS.}

Necdle leaf or coniferous wouls comstitute by far the greatest amumat of lumber used. The trees, with the exception of the junipers, bear distinet cones, and. excepting hald cypess amel the iarches, have evergreen or mon deciduons foliage. The worlinclucle the softest, lightest and most eavily worked kinels and may be characterized ats ontaining resin and having no sisille pores on the end grain.

The shif pines are complaratively free from resin, light.

SOFT HINES easly worked, soft and nut strong, suitable for the calinet maker, jomer, carpenter. patterm maker, and a variety of special purposes. The mont inpertant of them is white pine.

White Pine, whe of the most valuahle timber trees of the world, was

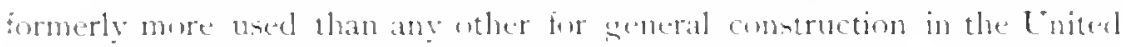

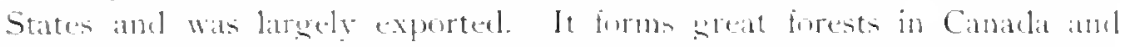
the mortheatern Cnifed States and also grom throughout the Appalathian

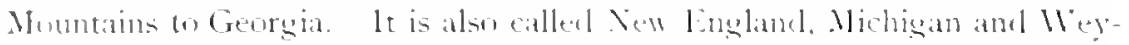

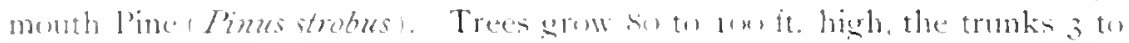

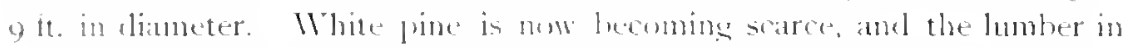

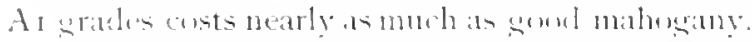

Sugar l'ine of the morthwestern [ nited Staten and british Columbia,

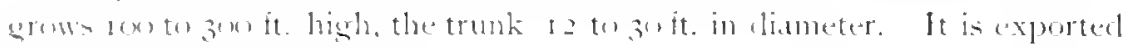
ar. China, Jayatn and Hatwaii.

Wentern White l'me of the Sorthuse in also a large tree and Rocky

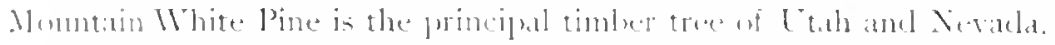

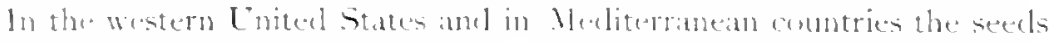

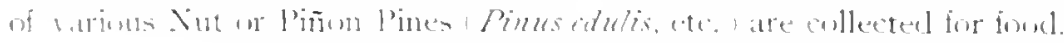

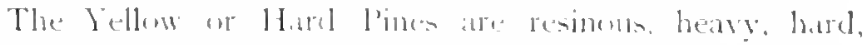

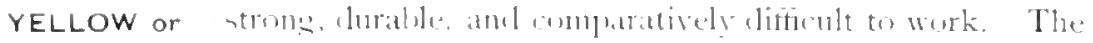

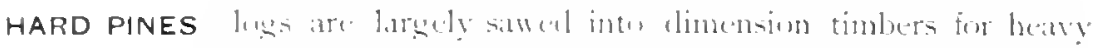

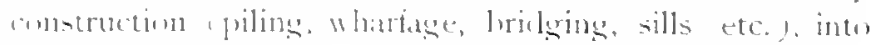

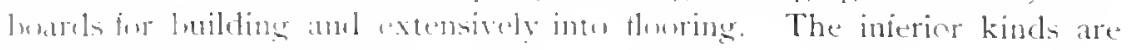

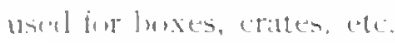

The following are the inpurtant vatiotin:-

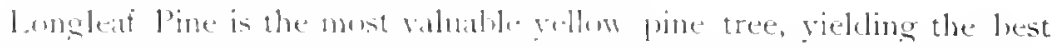

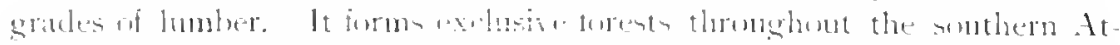

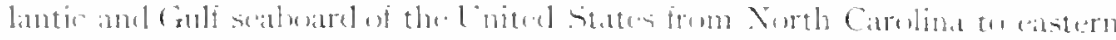

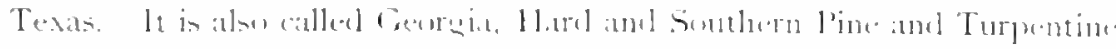

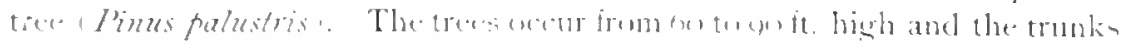
Hom $2 \mathrm{I}=20+\mathrm{it}$. in dismeter.

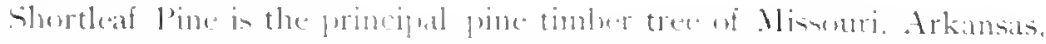

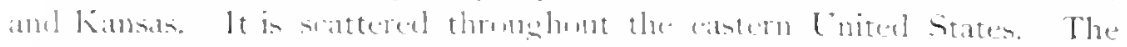

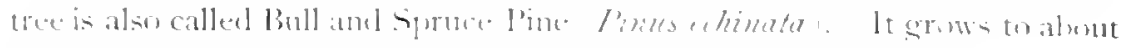

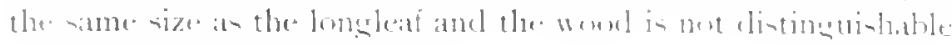




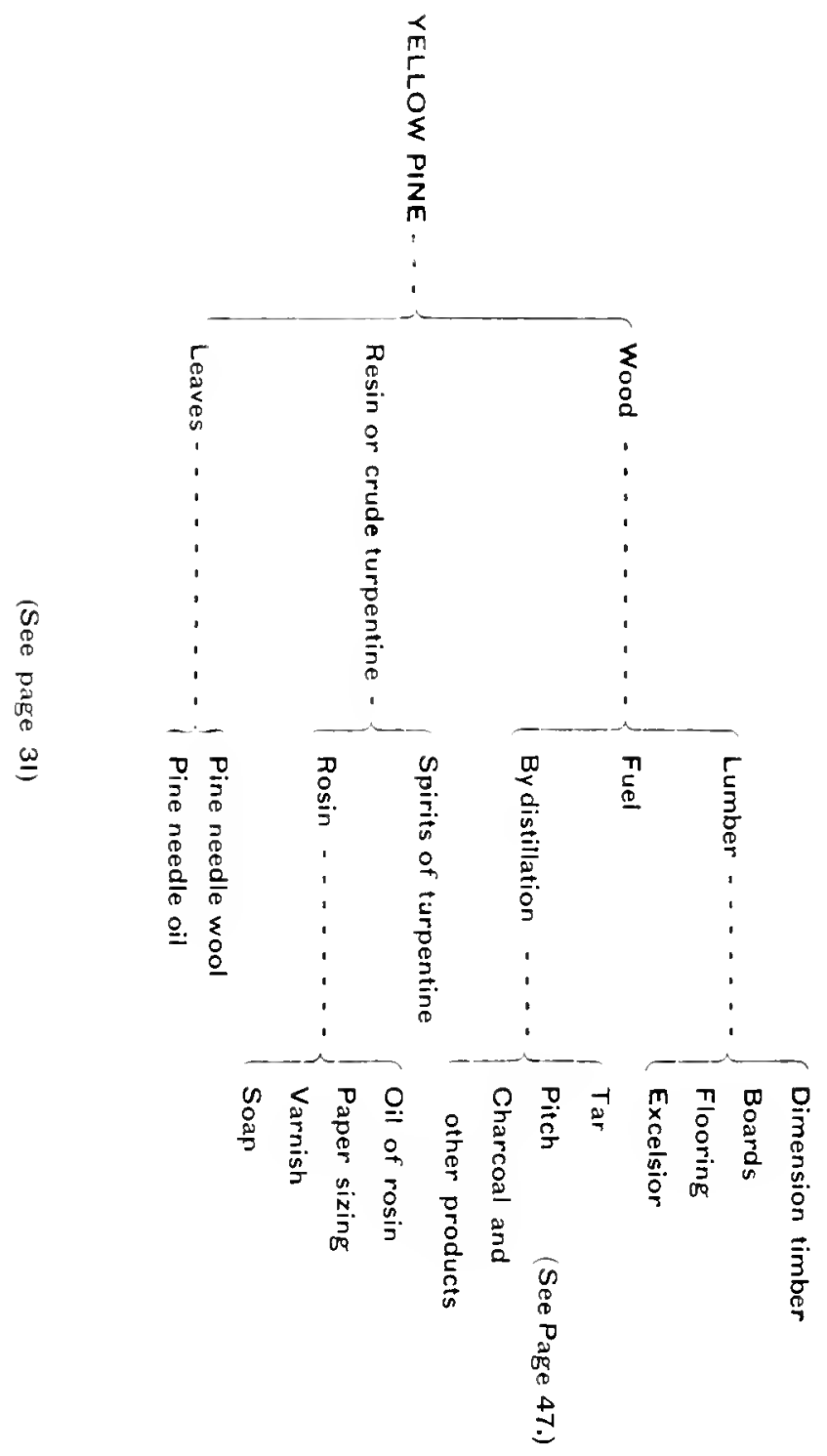




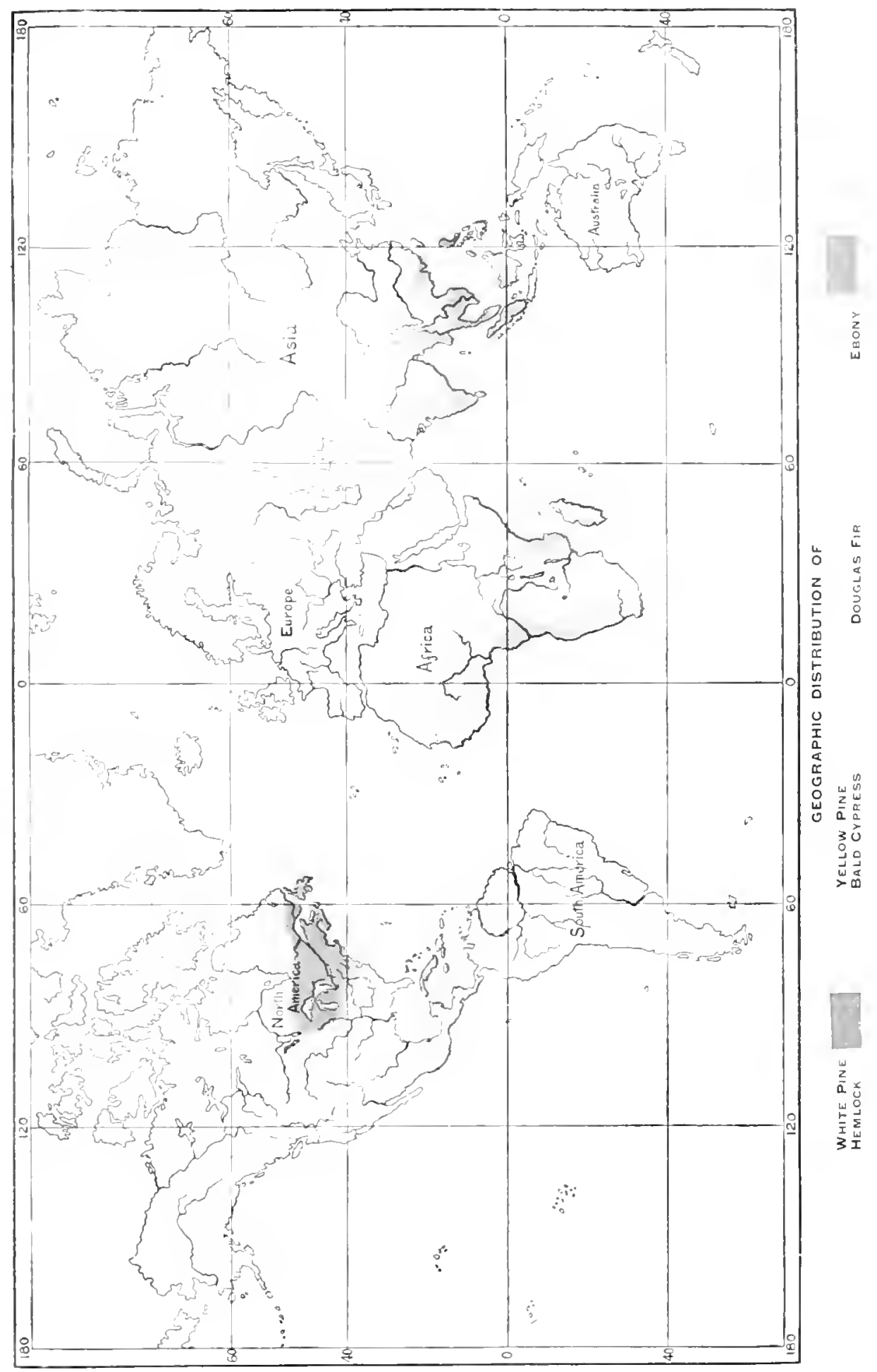


Cuban l'ine is found near the enast trom Chatentun, S. C., to Missin sippi ame also in the West Indies and Central Americat. It is called slantr. Swamp, Mearlow and Pitch Pine (Pines abensis). The trees are somewhat larger than the longleat pine and the woul is harly. inferior.

loblully line is scattered, on in aroves thromghout the eastern Inited States south of Maryland. Lumber known to the trate as North Citrolina pine is cut almost entirely from this tree (Pinks tadd). The names (h)

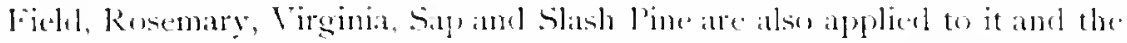
lumbermen frequently confuse it with the shortleaf. The trees grow from

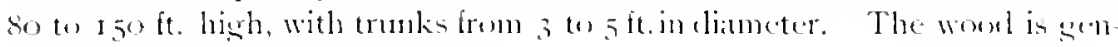
crally inferior to longleat pine.

Western Vellow Pine is a large tree, common in jurtions of the Rurky Nomutains, the Coast Range and the intermediate vallegs from interion British Columbia to Mexico. It is also called bull Pinte ('inus ponderosed.

Red l'ine grows in southern Canarla, and the morthern Lnited States. It is cut and marketed with White Pine. It is called incorrectly Norway l'ine.

Forthern Pine of Eurupe and northwestern Asia is also called Vellow Deal, Redwood, Scotch, Nemal, and Dantzic Fir. The wood is similar to the yellow pine of the Enited States.

Crude turpentine is a semi-fluid, sticky resin exuded from CRUDE wounds mate in the trunks of several trees betomging to TURPENTINE the Pine family. It is produced chiefly in the Lnited States, Finland, Russia, Austria, France and India. In the Inited States it is obtained almost exclusively from the hongleaf or yellow pine tree (Pinus palustris). Turpentine is usually olstained in the following manner: the trees are wounded by removing a wide strip of hark on one side and cutting below this into the wood of the tree a pocket-like carity kmown as at "box." The wound thus made discharges the fluid intw the pocket, which looks two or three pints and is filled in about ten days. The turpentine is then cliped out and the wound re-opened to stimulate a further flow. By. more moxlern ant careful methods the turpentine is caught in vessels which are lnumg on the trees, which are thus not rumed by the removal of solarge a stripof hark and are not weakened ly the cutting of the "box." In this way, the yield of turpentise is increased and the life of the tree lengthened. The crude turpentine, which consists of a resin dissolved in a volatile oil, is pht inte a still with water and distilled. The steam, ingoing wer in the still, carries the volutile oil with $i t$, and the distillate is allowed to cool in a rat. The water and oil separate into two hycers, amd the latter is drawn off in harrels for market. It is known as spirits of turpentine, or oil of turpentine, and is largely used for dissolving resins for varnishes and for mixing paints. It is used in medicine and in veterinary practice as a liniment.

The residue remaining in the still is a solid sulstance of an amber

ROSiN or hackish-brown color known as som or colophong. The colot varies according to the purity of the rosin and the degree of heat used in its preparation. In this country three sardes are in the market "virgin," "yellow dip," andel "batel." Jirgin rosin is matelefom the first 
turpentine that exudes after the tree in "buxed." It is of a very light yellow or amber color. The srester part of the crucle turpentine furnishes yellow dip. Harl rusin is almost black in color and is made from the scrapings from the trce after the turpentine has lecome ton hard to rum.

Rosin is uned in making sones and varnishes and for sizing paper. It is used by tinners and phumbers as a flux for their solder: ly founders for giving tenacity to their cores; for making medicinal plasters and sealing wax and for rubling on vinlin lums. It is used in ship caulking: as an adulterant of fats, waxes, anel mineral oils; and for mixing with tallow to make common canclles. When rosin is heated in a retort it is decomposed into certain gases, liepuicls, ancl pitch see also Tar). The liguid distillate is chiefly rosin spirit and rusin wil, the former resembling oil of turpentine. These are used in ramish making and for "rosin grease "-a lubricant.

Pine Veedle IVoml, used for stuffing mattresses, pillows and for making mats amel rugs, is male from the leaves of the longleaf, Cuban, European and westem rellow pines, and from these species Pine Needle Oil, used medicinally, is also made.

The Spruces are valuable trees furnishing soft, light, very white

SPRUCE Mond, the beatt mit enily distinguishable from the sap. The treen are of mothern gromth, and wide distribution. The mood is used commonly for construction and more than any other kinds for making paper pulpe.

White. Spruce, since the scarcity of white pine, has become an important timber tree. It in mot fomel south of the foth parallel in the Inited States. lut forms vast forests throughout Canadis as far north as Jabrador and Alaska. The trees (Picea canadensis) gurw $60 \mathrm{to} 150 \mathrm{ft}$. high, the trunks 3 in $5 \mathrm{ft}$. in diameter. The wood has a satiny lustre.

black Spruce is very similar on the preceding with nearly the same range (Pices markma).

Red Siruce in a smewhat smaller tree (Plice rubra) growing as far stuth ats Vorth Carulina, on the high peatis af the Alleghanies. The wood is not distinguishalde from white spruce.

Tirledurl Spruce is one of the laresen and most important timber trees wh the Pacifie northest. The word is ned for lonat buileling, cooperage, wentenware, showken, exedsior, interion hish, fencing, piling, carpentry,

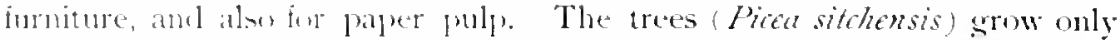
near the orint, from A Aaskat to California, and reatch a height of 200 to 300 lt. .mel + 11 20 it. in dimeter of trunk.

Xirway Sinuce is une of the must useful trees of Europe, and has been

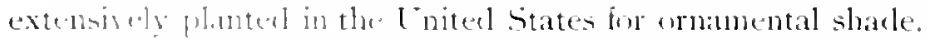

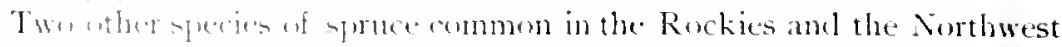
are cut lowlly for lunlug. These are Fngelmamis and the Blue Spruce.

l'he. Ilemplickis are trees of the first ecommic value, and

HEMLOCK hamelnemmenure sin since the scarcity of pine. The wool in plintery pinkish white in color, coarse srained, and easily worked thumh wour 


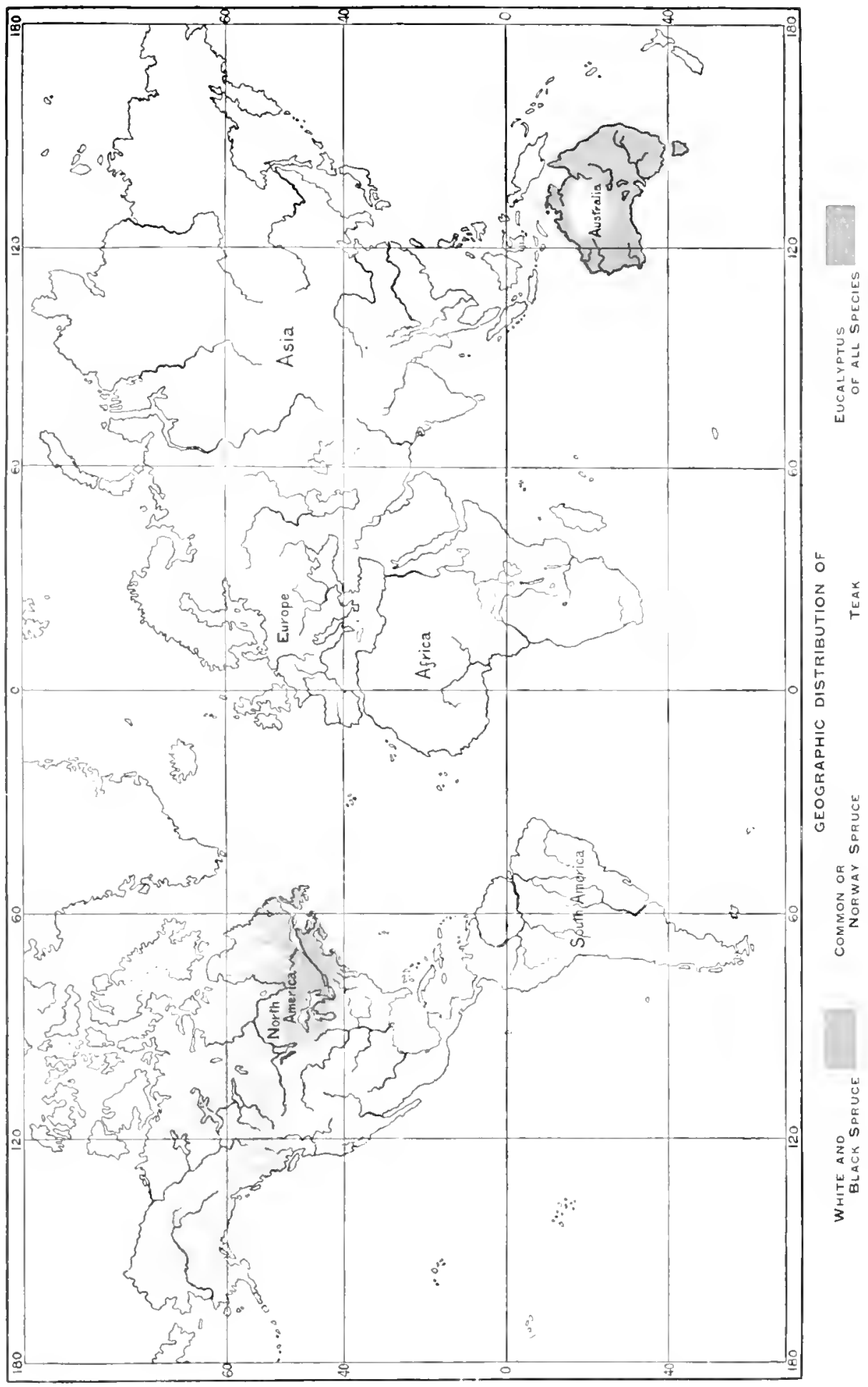



Fastern Hemlock is used nume than other trees for framing timbers, scantling, sheathing, etc. It occurs in southoastern Canadia and the northeastern Lnited States, and grows to a height of 60 to so ft. With a trunk from 2 to 3 ft. in diameter ( Tsuga canadensis).

Western Hembek furnishes a wond superior to that if the cistern species. It is used also for wainscoting, stair work, and turning. The trees srow from 100 to 150 fl. high, the trunks 2 to $8 \mathrm{ft}$. in diameter (Tsuga heterophllla).

The Firs, with the exception of two species, furnish wood that is FIR coarse graned and inferior to that of the other conifers. It is used mainly for light coustruction, packing cases, paper pulp. and charcual.

1)ouglas Fir is the most abundant and useful tree of the Pacific coast, and is fonnd throughout the Rencky. Nountains. The wood is used for lseavy construction, hridsing, piling, railroad tices, sash, deors, fooring, shiphuilding, furniture, and especially for masts and spars, for which it is extensively

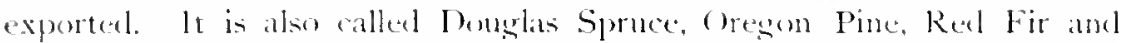

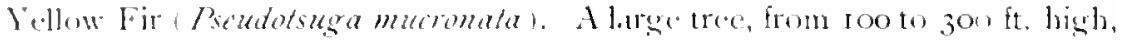
with a trunk 2 to 15 ft, in cliameter, it semetimes furnisbes logs clear of limb go teet long.

Noble Fir yelels a woul that is hard, stroug and elastic. The tree is

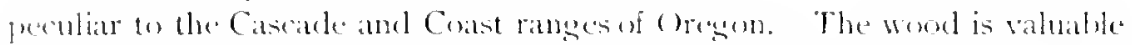
for aeneral construction, lomethulding and furniture. It is also called Red

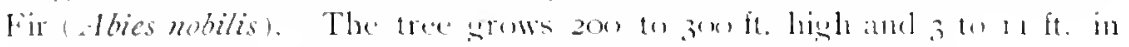
diameter of trunk. The woul is light bown, streaterl with real.

White lir, common in the morthese Lnited states and British Colum-

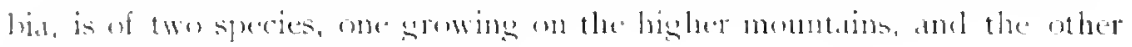
mathe obstat and in the balleys.

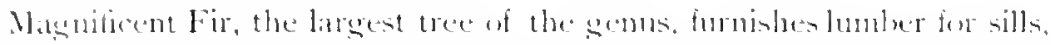

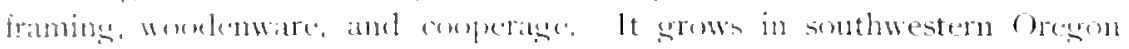

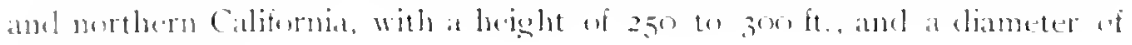
from 0 (1) $12 \mathrm{ft}$.

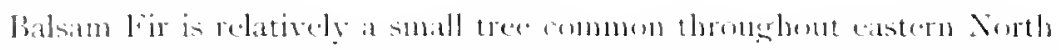

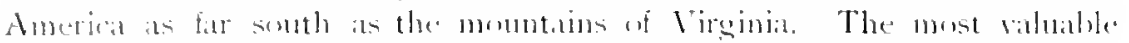

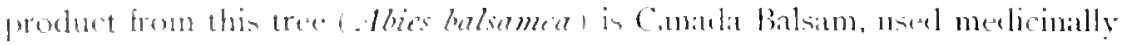
and in llu ante.

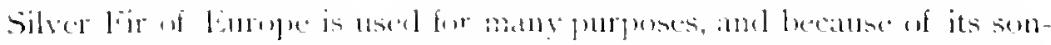

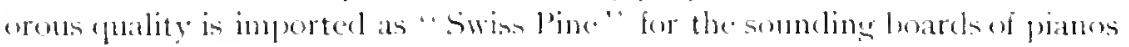
and violins.

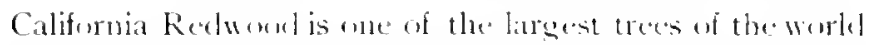

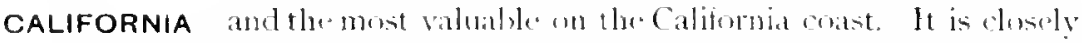

REDWOOD reliated, ansel lats wond bery similat, w the famols big trees of California. The woret is especially valuable in shingles, tanks, coffins anel lisht anntruction. The trees (. Siqueid semper

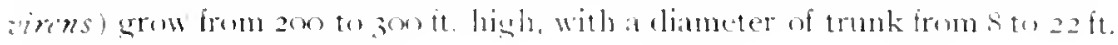




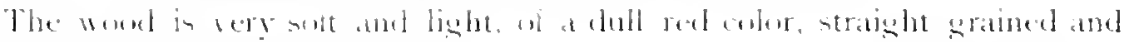
dies mot warp on shrink reatily.

The farchen formish wout that is stroms and very durable,

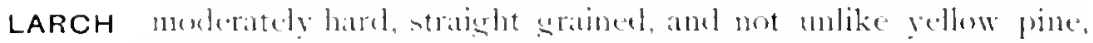

lout bess resinous. The word is used for ship timbers, telenraph

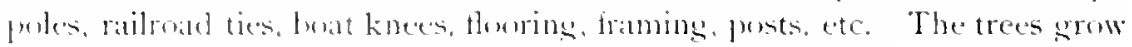

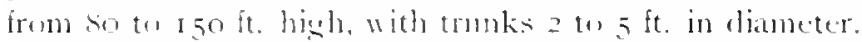

Fantern Latrd is found in Canala and the northeastern Enited States. It is alsi, called Tamarack and lHackmatack (Laria ameriana).

IVestern Larch is abmelant in British Columbia and the Northwest. The name Tambarack is also applied to it (Larix oridentalis).

European lated suows in the Aly af central Eurne and in lapland. Nomaly and siberia. The worl is essed especially for piling an account of its duralility.

Cypress is a rather seneral term for many wouts atlied to, or

CYPRESS identical with the Cedars. The woud is distincty granded, soft, cuarse, and used for calninet work, interior finish, shingles, framing. pusts, etc.

badel Cypress is common along the southern const of the Luited States. from I tedware to southern Texas, and in the kner Mississippi latley. The tree (Taxodium distichum) wroms from to to 1 fo feet high, with a diameter of trunk 5 to $\mathrm{I} 2$ leet.

Vellow Cypress grows near the const from Sitka to (1)egom. It is also called Alaski Cedar (Chamacoparis noothatensis).

Lawson's Cypress of Oregon and mothern California, smoning near the cont, is also called Port Orforel Cedar, and Ginger l'ine (Chamactparis laa'soniana). It grows from ion to $200 \mathrm{ft}$. high ant has a trunk from 2 to $6 \mathrm{ft}$. in diameter.

Cypress of the OAd $1 V^{\circ}$ ord is a common tree of the Metiterranean region of Eurpe, Asia Minor and Persia. Exyptian mummy cases and ancient gates mate of this wood were sount after i 100 years.

Cypess l'inc is a valuable tree of Australia, having a fine figured wood, with a camphor-like fragrance, used for furniture.

Indian Cypress grows in the Himalaya Mountains and furnishes brown, harel woul use for building.

The White Cetars are so calleet to distinguish the WHITE CEDAR wood from the Reel Cedars or funipers. The coler of the heartwend. however, may be gravish pink or bown. The trees are cut largely for posts, telegraph poles, fencinge and sylit shingles and are sawed into humber for tanks, hoats and wooden wate. The wood in very frastant.

Incense Cedar is a common tree of ()reson and Callifmuia. The trees

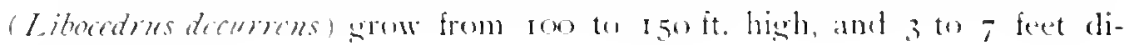
ameter of trumk. 


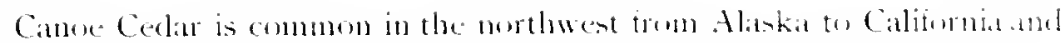
Nontana. It is also called Giant amel Reel Colar (Thusa plicata). The. heart woul is redelish brown.

Common White Cerlat serows alome the rastern const of the linited

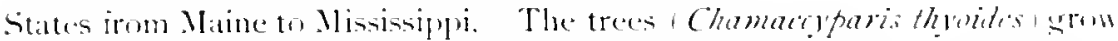
50 to - G it. high with trunks 2 te 3 ft. in liame.ter.

Arber Vitace a small tree commen in Cancela and the nurtheantern

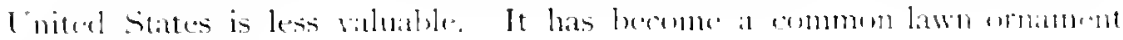
amel heclue tree.

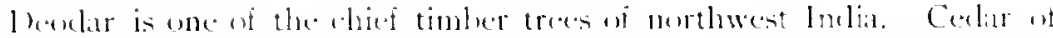

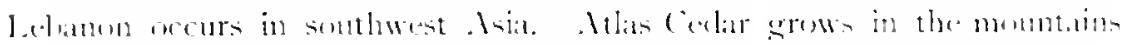
of morth tricict.

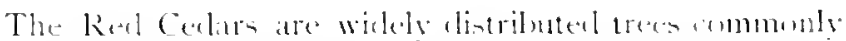

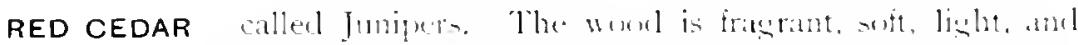

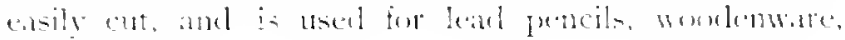
chests, cibinets and fince justh.

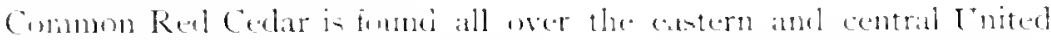

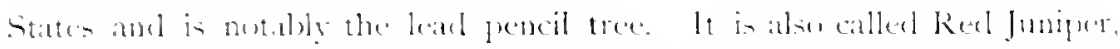

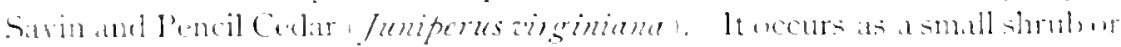

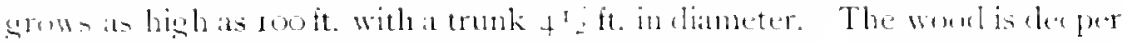

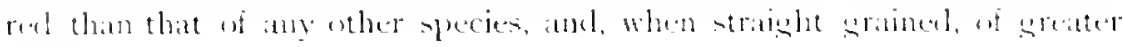
value.

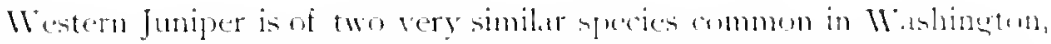

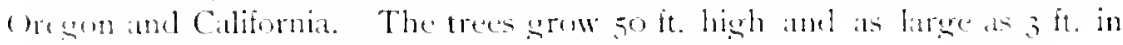
dianseter of trunk, but are aften only low shrube.

\section{THE BROAD LEAVED WOODS.}

The lormel leaved woods are from these then that are senctally termed

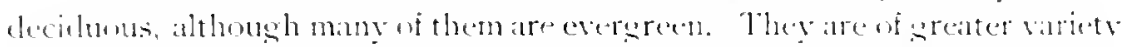
and weler distritnum than the coniferoms trees amd the wouls are more

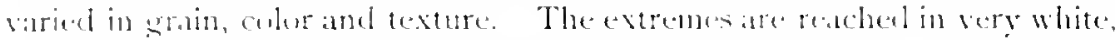
jet liack. rish red, and brisht yellow, and they inclute the hardest and strungest warris. They are not resinoms.

The softer broad leaved woods of the most important species are at fellow:- -

Tulip Porplar, a ine of the first economic importance

TULIP POPLAR and the laresest tree in the edistern Cnited States, is ammmon in the Mississippi Valley and the Athantir Stated suth of Vermont. The wool is useel for a areat bariety if purposes in which it now bargely takes the place of white pine. It is also called Tulip tree and Whitewond (Ciriodentron tulipitera). It grows to a beight of 12540250

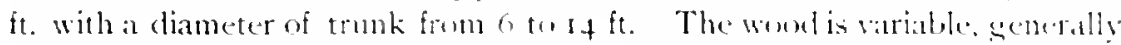
soit, easily worked, not duralite, cohr yellowish white, whating to greeni-h or brownish. 
The Lindens are important trees furnishing soft, light, smooth

LINDEN wood of a light color used for general construction and for many special purposes, such as carriage bodies, handles, cooperage, paper pulp and gunpowder charcoal.

American Linden is common throughout southeastern Canada and northeastern and central United States. It is also called Basswood, Lime, Bee tree, Lin and Whitewood (Tilia ameriana). The trees occur from 70 to So It. high with trunks 3 to 4 It. in diameter.

White Basswood, a tree found in the central United States, is very similar to and commercially confounded with the foregoing. It is also called Wahoo ( Tilia heterophylla).

European Linden is of three species common in Europe. These are also called Lime trees or Lins. The wood is used for carvings, druggist boxes, etc. I.inden bast fiber prepared from the inner bark is used for cordage, mats, hagging, and fishing nets.

Cottonwood, similar to linden, is used for much the COTTONWOOD same purposes, and very extensively for paper pulp. It is found throughout the eastern and central United States, reaching its wreatest development in the south and west of the Mississippi. It is also called Carolina and Necklace Poplar (Populus deltoides). The trees grow from 80 to 775 [t. high and from 4 to $8 \mathrm{ft}$. in diameter of trunk. The wood is soft, fibrous, light, and grayish white, or brown.

The close grained, typically hard woods (in which the grain pits are not conspicuous) are of many important species.

The Niaples furnish wood that is compact, tough, susceptible

MAPLE of a fine polish and often beautifully grained or figured, being then variously called " curly, " "bird's cye," "blister," "landscape," and "fiddle lack " maple. The wood is extensively used for vencerins, flooring, furniture, the backs of violins, wooden bowls, shoe lasts, rulers, tool hanclles, and inlay work. It is especially valuable for charcoal and potash.

Sugar Maple is a tree of the first economic importance in North America, growing in southeastern Canada and the northeastern states along the Alleghany Mtountains to Georgia and also in west Florida. It is also called Hard and Rock Maple (Aier sacharmm). The trees grow 50 to roo $\mathrm{ft}$. high with trunks $210+$ It. in cliameter. The word is hard and most commonly furnisles the figured forms. Matple sugar is chiefly taken from this wee. The sap is trawn off by talpling the trunks in carly spring and is then friled down until it is of the desired consistency.

Red Miple is a similar tree soming throughout the eastern and western

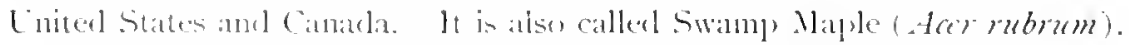
The worel is darker and less valuable than susar maple.

Silver Maple is alsu common thromghout the eastern and central United

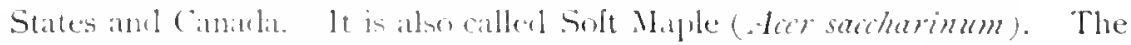
wood is inferitor and less used than sugar majele. 
Broad Leaved Maple is a valuable tree common on the Pacific coast from Alaska to California. It is also called Oregon Maple (Acer maorophyllum).

Common Maple of Europe and northern Asia is a valuable cabinet wout.

Norway Maple of northern Europe and Switzerlanel is not commercially distinguished from the preceding. It is extensively planted in the United States as a shade tree (.ter platanoides).

Sycamore Naple of Europe and western Asia furnishes a wood similar to and often confused with the preceling. Other species are the Himalayan Maples and the Japanese Naples used for cabinet and carpenter work.

Several species of Birch furnish wond which is hard, strong, com-

BIRCH pact and fine grained. It is used for a variety of purposes, such as making handles, clothes pins, took, shoe pegs, wrodenware, wheel hubs, fellies, fruit baskets and boxes, veneers, furniture, anel for charcral.

Cherry Birch, the most important and zenerally useel of the North American birches, is found throughout the northeastern [nited States and southern Canada and in 'Temnessece. It is also called Black, Sweet, and Mahogany Birch (Betula linta). The wood is reddish and the trees yrom from 60 to soft. in height with trunks 2 to $3 \mathrm{ft}$. in dianter. Wary or figured grain, called "curly" hirch, is highly prized aml shows a beautiful golden satiny lustre.

Yellow Birch, of much the same licality as the preceding, furnishes wood that is lighter in color (Betula lutea).

paper Birch is similar to Veltow Birch, and is found from Labrador to Alaska and from Maine to Washington. It is alsor called Canoe Birch ( Betuld papirifera). The bark of this tree is peeted off and used for making canoes, tent- and fance articles.

Luropean Birch, of morthern lurnpe and A ala, is very similar to American Cleery Birch. The bark is used extemilely fur haskets. buts cordage, dyeing and tanning.

beech is a valuable woun for many purpuste. It is heary hard,

BEECH strong, compact and fim errainel, and of a linht loronor pinkish brown color. the rateliating rays heing yuite distinct. It is used for tools, handles, chulles pins. wagen stock, shoe lasts and for grunpowter charcoil. The trees grou from suto and high, with trunks 2 to + it. in diameter.

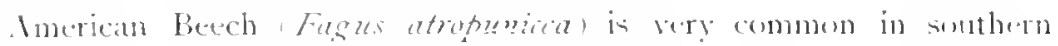
Canarla and eastern and contral [nuterl stater.

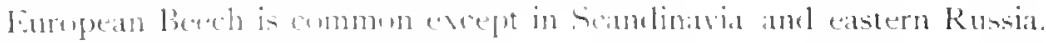
The wend is used lategely for saluts.

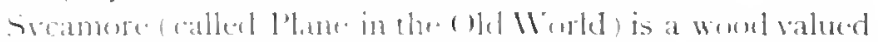

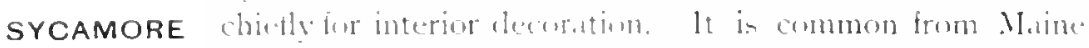
(1) Fluriela, abel from Xifrabate Texas. The woont is liehe

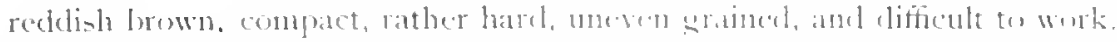

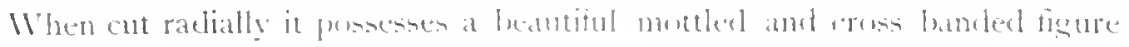




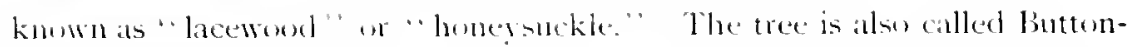
ball Platames ocidentatis). It grows from go to $1.35 \mathrm{ft}$. high, and from 5 to $12 \mathrm{ft}$. in diumeter of trunk.

Eistem l'ame is found in southeatern Europe and sombluestern Asia.

Holly is a mother small tree, the rery white close grained wood HOLLy of which is much mad for fancy articles, turnery, fret sawing, inly work, carring amel almost exchsively for picture burning.

Anerican Holly a /lex opace is common in certain incalities from Massachusetts to Missoniri and from firmila to eastern Texas.

European Holy in fomml in contral Emope and western Asia.

The open grained hard woods (with the arain pits very compicuous) of light colur are all used for a wreat variety of purpuses. The varions shades of finished woul, in furniture, ealnet work, and interior feoration, such as

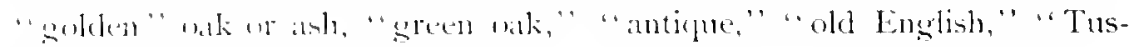
ciul, "tc, are entirely the result of fillers put on to close up the pores before the varnishen are applied.

Cokes are of mamy species, most of which are very useful. To

OAKS Inmbermen in the Enited States they are knomm as White Oak,

Live (): and Red o.k, and the species are hardly distinguished

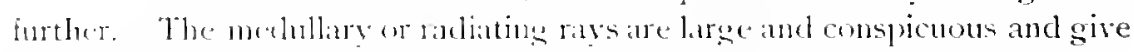
leatifully figured arain when " "guartered," or siwed from the bark to the conter of the trex, paralled to these rays. To effect this best the logs are rut in puarters before cutting into brords, whenec the name. Boards cut in the ordinary manner and showing the radiating ratys cut at right angles are catlerl "plain" silwerl or "straight nak."

White Oaks are harel, tomgh, strong, clastic and durable WHITE OAK and generally of a light groyish brown with a pale pink tinge. The trees are cut for lridge and building timbers, railroarl ties and posts; also for lumber for fumiture, coperige, agricultural implements, wagon stock, and especially when quarter sawn, for fine cabinet wrk, interior finish, flooring, etc. The white oaks are as as follows:

White Oak is common from Maine to Michigan and Missouri, and from Frivla to central Texis. The trees ( Quercus alba) grow from so to i $50 \mathrm{ft}$. hish, and the trunks from + to $\mathrm{S} f \mathrm{f}$. in diameter. The bark is used for t.muning.

Burr Oak in very similar to the preceding with a somewhat more northern ranse. The woul is possibly harder and tomgher. It is also called Mossy(up ()ik ( Oucrus macrocarpa).

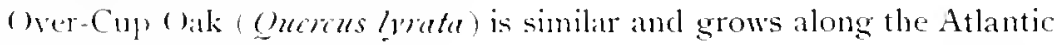
anat from Delitwatre to Texals.

Chestnut ( hak grows only in the eastern and central states from Massachusettis to Tenuenter. From the bark and wool of this (Queres prinus) and the two following species, mone than from other Ameriom oaks, are made extracts extensicely unet in timning. 


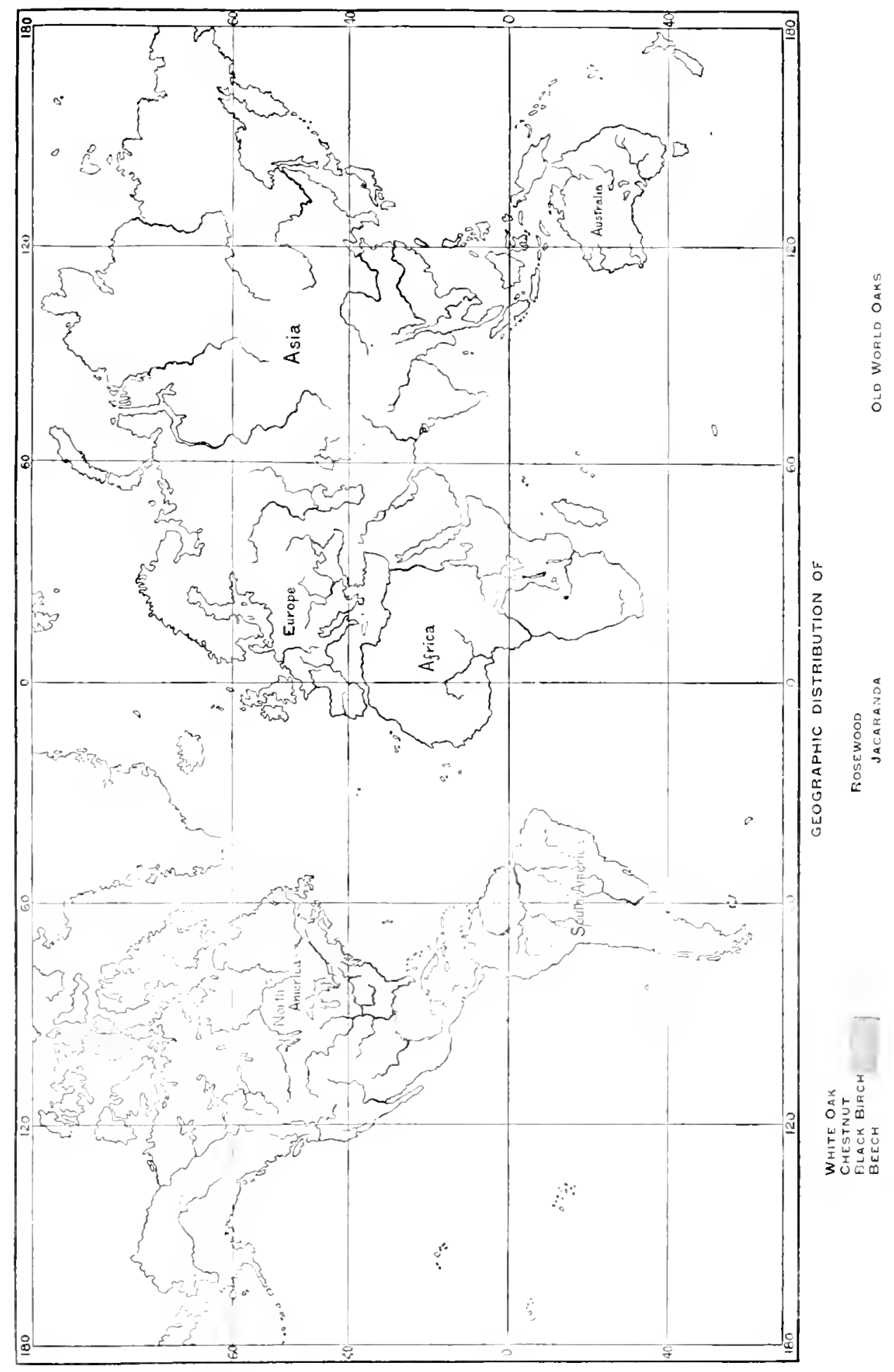





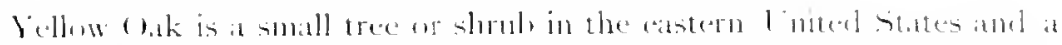

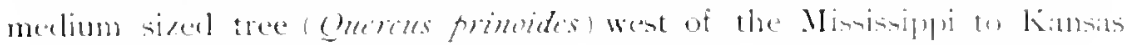
and western Texas.

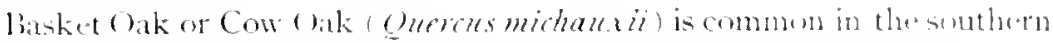
staten from Delaware and Kenturky, to Florida and central Texas.

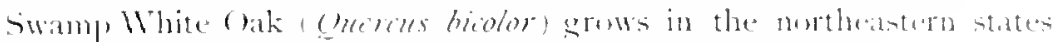

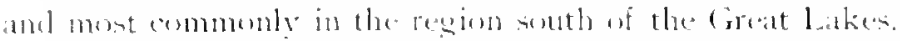

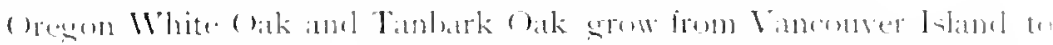

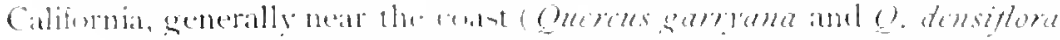

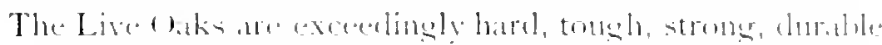

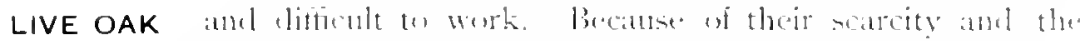
small whe of the trees they are used only for special pur

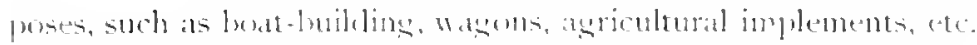

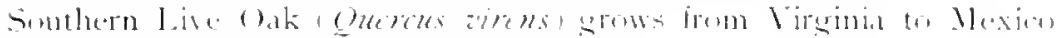
alome the const and in western Texar.

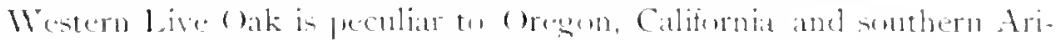

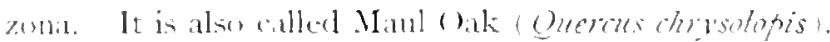

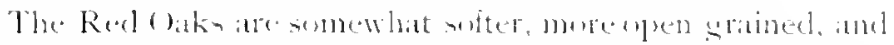

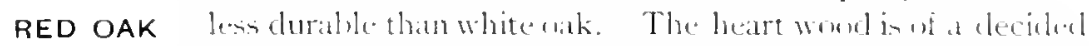
pink of light red colos. They timel muld the same aceneral

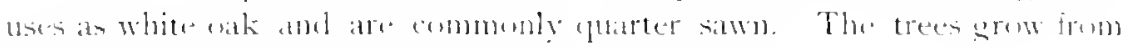

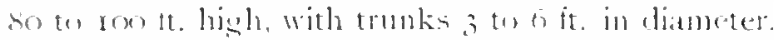

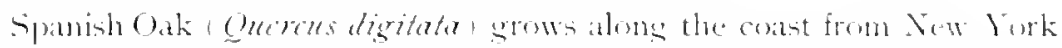

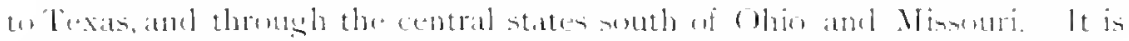
alsw calleel Red oak. The woul is atensively used for comperatge and furniture.

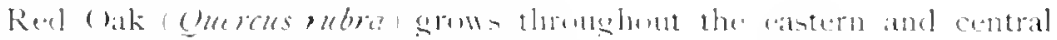

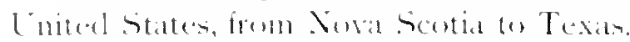

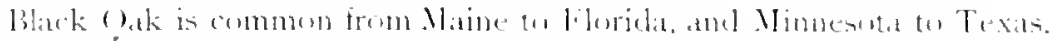

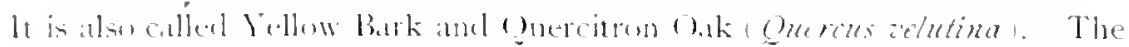

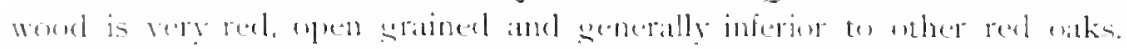

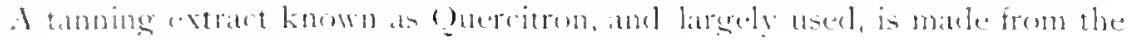

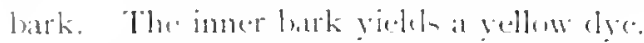

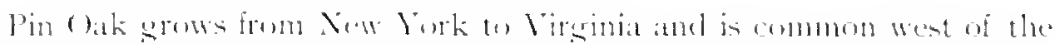

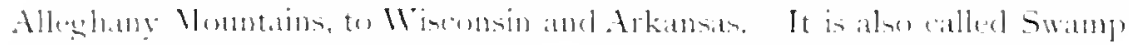

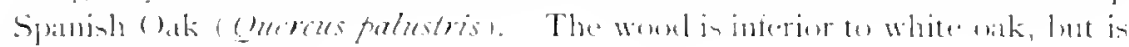
sometimess sold fire it.

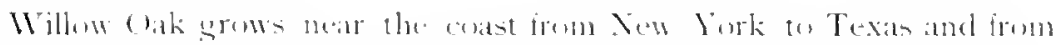

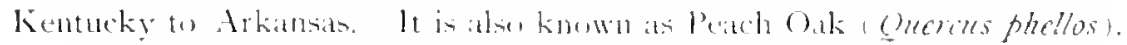

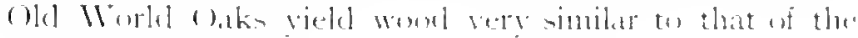

OLD WORLD American ypecien.

OAKS

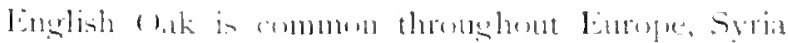

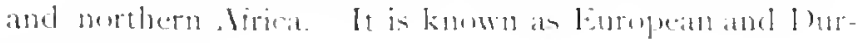

mant (bak (Gueres rohm). 
Turkey ()ak of midetle and southern liurnpe and western tsia is also known as Adriatic, lom, and Wainsent Oak ( Ouereus amis).

There are several species af important timber oaks in lndia (the Himalavan region) and several in fingm. Mang of these trees are evergreen and betane to the live ataks.

In one European specier of rak (Quous subr) the hark is uncork ushally thick and spongry and the outer laser can be stripped off without injury to the tree. The probluct ai the first stripping, called virgin eork, is rough. It is uned chiefly for taming and for decorative purpunes by flurists. In from six to ten years another layer can be removed. The best cork comes from old trees. It is taken off in large sheets, dipled in hot water, pressecl Hat, dried, and haled for shipment. Corks are cut hy machinery and the cuttings and waste are used in making linolem and life premervers. Cork is produced principally in Portugal. Alyeria, Span, whthern France. Tunis, Italy, Moruca, Greece and Austria.

Ash is a wood of great value lecatse of its stremgth, elasticity and

ASH comparative lightness. It is easy to work and its many excellent yualities cause it to be used for agricultural implements, carriages, bugsy shafts, oars, fishing rods, etc. It is also empleyed for furniture, interior of cars, boat cabins and building. There are sereral species, of which the most important is the first named.

White Ash grows throughout the eantern and central Lnited States. from sontheatern Canda to Minnesoti and Texas. The trees Fraxims ameriand ) are from 50 to $25 \mathrm{ft}$. high with trunk dianeters of $+\mathrm{to} 6 \mathrm{ft}$.

()regon Ash grows from Washington to California along the coast.

Red Ash, Green Ash, Black Ash, and Blue Ash are all small or medium sized trees growing in the eastern or central Lnited States.

European Asl is a native of all Europe and morth Africa. It is also called Common Ash. Curly forms of the wood accur in Hungary that are much prized for furniture and are imported to the Enited States.

Shioni-Noki, the common ash of Japin, is similar to ou smaller ashes anel is nised similarly.

Chestnut is included among the so-called harel woods, CHESTNUT althengh it is solt, light, not strong, and is easily split and worked. Formerly little used except for fencing and rough construction, it has now hecome une of the most commonly used calbinet wounde. It is upen grained, very decorative because of the wide anual ringe, light brown in color and has much the appearance of, and is often used as a sulstitute for, plain sawed oak in furniture and interion finish. It is very durable. The young trees are extensively cut for telegraph poles. The worel is also used for making charcenal and a tamning extract is mate from the woul and lark. The nuts are an important article of commerce.

Amerion Chestnut in common thromghont the northern Lnited States

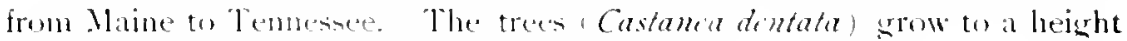
of rooft. and the trunks $+41,12 \mathrm{ft}$. in cliameter. 


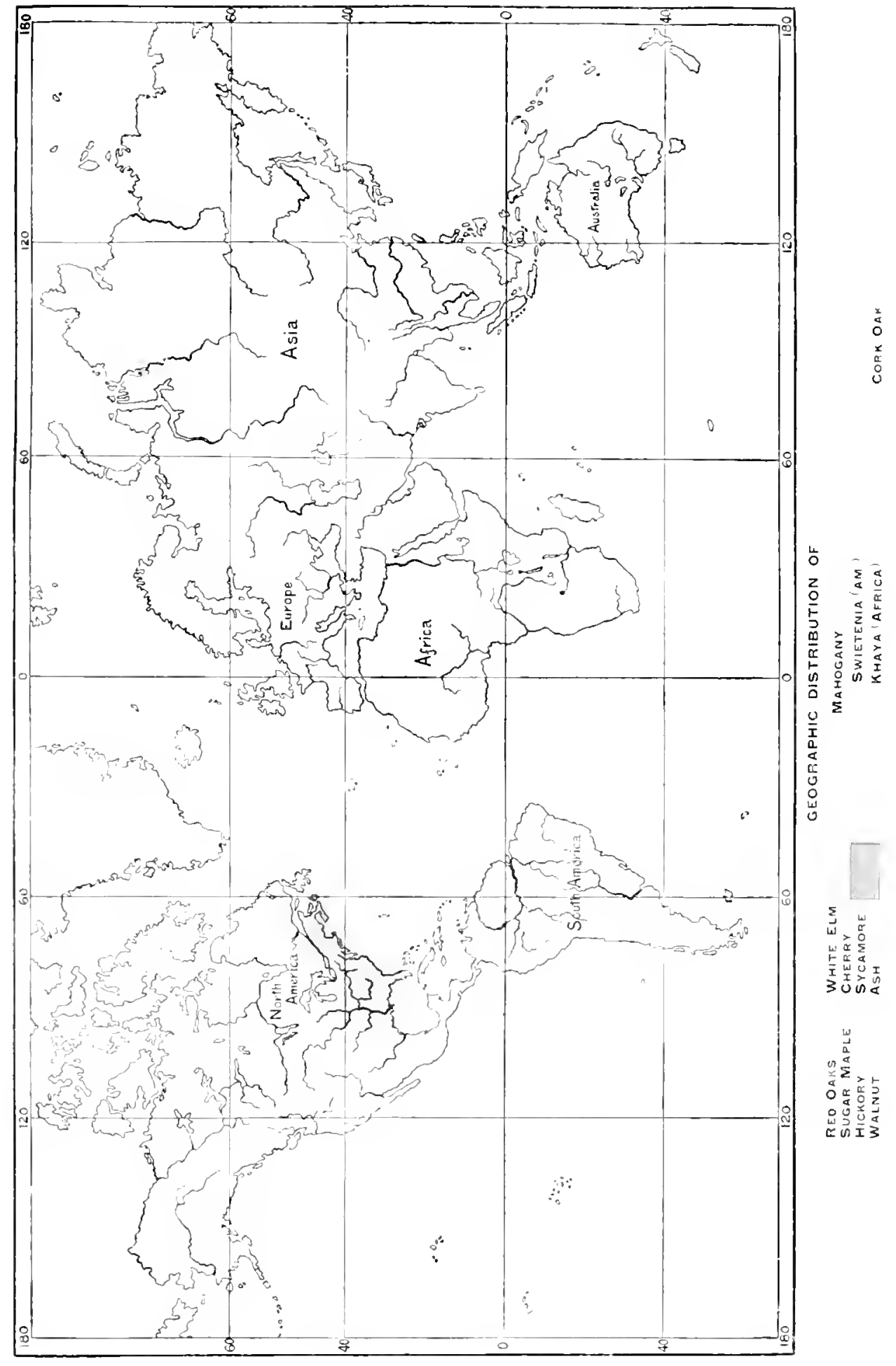



European Chestnut is very similar, the trees often reaching an emormous girth.

Elm is, for special uses, a very desirable womel. It is similat to aste,

ELM hut tomgher, stronger, equally dastic and even easier to wark. The. grain is similar to ash, hut the texture is velvety and the color grayish. It is used for boat-huidding, wagon spokes, extensively for follies, the rims of metal whecls, for agricultural implements, butcher blocks, ardriages, toul handles, comperage, fooring, ete.

American Elm prows from southern Xewfoundland to the Canalian Rockies, south to Florida and northern lexas. It is also called White fin. ( $C$ \%mus ameriana). The trees srow roo it. high with trunks from + to - it in diameter.

Rock Eim is found from l'ermont and Ontario to Kentucky and Inwa. It is also called Cork Elm ( / /mus racomosa).

Red or Slippry Ehm, Cedar Fim, and Winged Elm or Waluo we smaller trees of the central and southern [nited States, the former as far north as (matirin.

English Ehm grows throughout Enupe. The wood is similar to American Elm.

Hickory is justly famous as one of the tomghest of woods and

HICKORY is, therefure, much used for purposes where strengrth is necess sary. It is very tough amb pliable when gareen, lut after thoroughly drying becomes stiff and somenhat frittle. It is sulpused to excel for wasm axles, spokes, fellies, axe, piok and hammer handles, rertain agricultural implements, etc. The white sapwond, thomgh senerally prefered, is not superior to the darker heartwod. The tresegrew from so to roo ft. high and with trunks from 3 to $f$ ft. in diameter. The woods of the several species donot differ. The species prow from suthern Onturin to Ninnesond, Florida and Texas.

Shell bark llickory is also called Shatg Bark (Hicoria orata). The. sureet, thin shelled nuts are an artirle of commeree.

Mockernut llickory is also known as King Nut, Bull Nut and White Heart Hickory (Thovia alla).

Pignut Hickory is called brown and liback llickory (Itioniug glabor).

Pecan (Ilicoria pecan) is common from lndiana to Sebraskat, and fo southern 'Texas. The wood is somewhat inferine to shell bark hickory; the nut stuperior to all other specises

loneust is useful for fence pests, railroad ties, sills, ete., hecause

LOCust of its great durability in contact with the soil. The Common Locust (Kobinia psendacacia) with yellow wool and the Hom.y Locust (Gleditschia triacanthos) with brownish red woud, both medium sized trees, are common in the eastern central Inited states.

The dark colored distinctly decorative woods native th the [ nitud States, are used almost exclusively for purposes where heauty of ondor and grain are essential. 
Black Walmut erows from Mansachusetts to Jorida, BLACK WALNUT and from Minnesotit te central Texas. It was formerly so sought alter as a favorite cabinet wond that it has become very scalue. It is now principally used for gun stocks, tumery, mouldings, inlay work and musical instruments. The trees (/uglans nigra) ercur [rom ioo to 150 ft. ligh with trunks from 6 to wo it. in diameter. The wod is ary dark brown or purplish brown molerately had and strong but eatsily worker. The nuts are edible.

Old Minlel Winnut is a mative of China and Persia and has been extensively intruluced throughout Europe, and is commonly kuown as English, Fremch and Italian Malnut. The word is user for grun stocks, cabinet work. veneering, etc.

Butternut (Juslens cimced) is similar to walnut, but solter

BUTTERNUT ame of a light pinkish hrown color. It grows from southern Canida and Minnesota to Mississippi and Arkansals. The nuts are edible.

Cherry has now hecome exceedingly scarce and high priced. CHERRY Few wools pussess its combined advantages of color, grain, texture and stability, these making it prized for pattern making, turning, printer's furniture, musical instruments, calbinet work, veneers, electrical instrument bases and interior finish. The tree that fumishes cherry lumber in Wila] Black Cherry (Pomus serotina), growing from Ontario to Florida and from Dakotil to Texas. It grows commonly as a shrub and as a tree from 30 to roo ft. high with a trunk from 6 inches to $f$ it. in diameter. The wood is light redelish brown, turning darker with age. The common deep red color is aiven it ly stain.

Sweet Gum is a tree now of great economic salue, the SWEET GUM wool being nsed for cabinet work, interior finish, fancy boxes, log turned lasket and hox veneers, conperage and to some extent for builking. The tree is common from New Jersey to Florida and Irom Missuri tu somthern Mexico. It is also called Bibsted, Red Gum and Hazel (Lipuidambar straciflua). The trees srow from roo to 150 it. high with a climeter of trumk from +406 ft. The wood is not heary nor harrl, and is of a lisht brown colest.

() reson Aleler is a tree of the Pacific Ciast, from Alaska

OREGON ALDER to Californis. The woud is extensively used for callinet work, carriage bedies and interior linish (Almes onsema). The woul is light redlish frown, harel and durable.

Imported Woods are almost all from tropical countries. They are

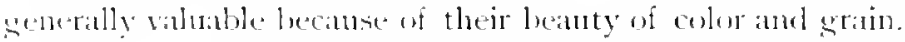

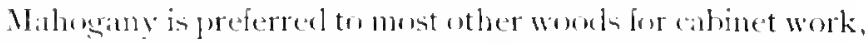

MAHOGANY and for at areat varety of purposes. It is aeneritly easily worked, and is uften of al leautiful color amd fientre. It is user for musical instrumenth, fince furniture, the best interior binish in houses, ars and the calims of shipe, for turnery, towl handles, inlaying, parquetry 
flowrs, electrical instruments, cameras and jewei boxes. The deepred rolor

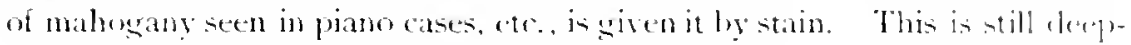
ened by the llood becoming darker with ace

American Mahogany is the common mahogany and grows in the Mest Inder, Central and northern South America. The best comes from Tabuson in Mexicuand from Santo Domingo: very good from lucatan, Cuba, ete, and inferion kinds from Honchuras and further south. It is also called liag

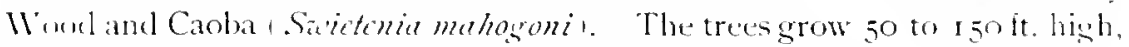
with trunks 1 to $f$ ft. in cliameter. The woul varies from pinkish white to reeklish brown, and from molerately soft to harel.

African Mahogany arows throushout the tropical west coast and inland. It is called Khaya (Khaye senegalensis. The wood is yellow ish hown, hard. heary and stromer and often lwantifully fienred. It is larecely imported into Europe.

mood ar che CIGAR-BOX wood of the West Indies, Central America and nurthern CEDAR South America. It is nsed for all kinds if general on struction, for boats, boxes, lubleling, cheap and fine furniture. cooperage, and is largely exported to the Lnited States and Europe for ciedr boxes and for furniture. Much of the so-ralled malogany furniture at this time is made of selected clark "Cedro" often figured, though it may le distinguished by the larger pits in the araiti. It is also known as Mest lndian Cedar (Cedrela odorata). The wood is lisht, soft, rery easily worked, colored from light yellowish to hrown, and is rery fragrant.

There are several species of so-called malusumy in Australia, the womds of which are dark red, often figured, hard, strong and durable and they are extensively used locally and exported. The most impurtant of these are as inllews:

Jirrah (Eucalyptus marginutu) srows in southwestern Australia.

Siwan, Nahoung yrows in Xew South Viles and is also called Red Malungany (Enculyptus mbusta).

Forest Mahogany is found in eastern Australia and is also known as Red and Gray Gum and Hickory (Emal lptus resinifora).

Moulmein Cedar is chosely allied to true mahngany. The wood is very similar, hut softer and generally darker recl. It lats a steat varicty of uses and is exportect largely. It is a mative of hortia, Jara, the Philippines and Australia. In India it is diso called Chitaseng Wood and Indian Mahogany and in Australia, Red and Pencil Ciedar (Cidede torna).

Teak is one of the most valuable of all wools. It is native in

TEAK India, Burma. Siam, the Naliyan Islands and the Plibippines. and is extensively cxported to Europe and occasionally to the Cnited States. It is the best timber for hip Inileling and for backing of armur plates, since it does not, like uak, corrucle the iron. It is usent for piling and wharfage, and is also largely uscel for rathoul cars, floming wum stocks amel furniture. The trees ( Fectonu grandis) arow so to roo ft. high 


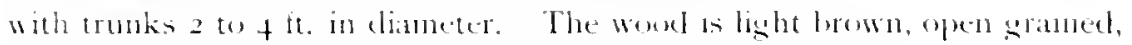
canily worked, somewhat oily and frastant, and very durable.

Certain fancy woods, aluable entirely beause wi their beauty of color anel grain, are brought into the L'nited States and Europe and used for musical instruments, inlay work, brush hacks, jewel boxes, knife and other handles, turnery and sometimes for fine furniture.

Ebony is found in tropical countries throughout the world, the

EBONY blackest coming Irom Cuba, hut now nearly exhausted, the most common, from the Gaboon coast, West Arrica, and very excellent from Madagascar, the Philippines, Bombay, Ceylon and Siam. It is for the most part a medium sized tree with broal white sapwood. The black heart comes into market in small logs. There are several species (Diospires, etc. i.

Rosewood or Jacaranda grows in South America and is supROSEWOOD posed to come Irom several trees (species of Dalbergia and Hachacrium). The wood is bright brown with black grain. A commercial rose oil is distilled from it.

Other fancy wods are: Cocobolo, from Central Anerica, bright red and black; cramadillo, a similar wood; Tulip wood, from Brazil, red and yellow; Amaranth, or Purple Heart, Irom South America, deep purple on exposure to light; Padauk, calted also Vermillion, Redwood and Indian líahogany, from China, Burma, Malaysian Islands and the Philippines; Indian Satin wood from Intia and Ceylon, deep yeltow; Prima Vera, called also White Mahogany, from Mexico and Central America, light yellow; and Olive wood, of the Nediterranean comtries, from which tree also comes the olive fruit, an extensive article of commerce, used as a table delicacy, and supplying olive oil.

Other tropical woods are imported because they are suited by color, hardness and strength for many special purposes. These are: Rule Boxwood, Irom the West Indies and South America, the bright yellow wood uned for rules. handles and inlaying; Lignum Vitae, from the Mest Indies, the hard, aily, greenish-brown heart and yellow sapwood used for pulley blocks, hearings, toul handles and caster wheels; Green-heart, from South and Central America and the Vest Indies, used for handles, brush backs and tibhing ruds, and Iancewood, from Jamacia, usecl for bows and fishing rods.

There are certain Australian wools used for general purposes of construction besides those alrealy mentioned. Red Gum is from eastern Australia and the Nurray River. The wood is hard, tough, strong and deep red, and is uned for heary construction. Allied to it are several other species of so-called gum, irombark, tallow wood, etc., alt belonging to Eucalyptus species. From the leaves of most of these trees Eucalyptus oil is (r may be cxtracted for medicinal nse. Other woods are: Honey-suckte. from southern Australia, prized for tecoration and appearing much like Sycamore of the Enited States; ses-called Oak, which is not an oak; 


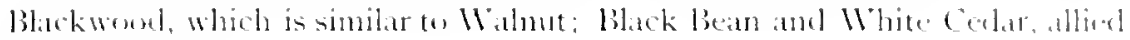
t) Nahusany.

When woul is heated in a retort, warinus gates are drin an

DISTILLATION off. Some of these gases, when patsed thromgh combled OF WOOD pipes, lecome condensed inter at liquid, and charoml is left in the retort. This proreess is callerl clistillation. liv re-distillation and treatment with certain chemicals, the lixpuiel may be made. to yed a variety of useful substanes ats is shown in the accomplanying ria gram. Oak, maple, birch, beech and pine are the kinds usually distilled.

\begin{tabular}{|c|c|c|c|c|}
\hline \multirow{2}{*}{ WOOD } & \multicolumn{2}{|c|}{ Charcoal } & Crude wood spirits & $\left\{\begin{array}{l}\text { Ammonia } \\
\text { Wood alcohol }\end{array}\right.$ \\
\hline & Liquid & $\begin{array}{l}\begin{array}{l}\text { Pyroligneous acid } \\
\text { or wood vinegar }\end{array} \\
\text { Tar }\left\{\begin{array}{l}\text { Creosote } \\
\text { Pitch }\end{array}\right.\end{array}$ & $\begin{array}{l}\text { Acetates } \\
\text { Tar }\end{array}$ & $\begin{array}{l}\text { Acetate of lime } \\
\text { Sugar of lead } \\
\text { Alum mordants } \\
\text { Acetic acid } \\
\text { Acetone } \\
\text {-chloroform }\end{array}$ \\
\hline
\end{tabular}

\section{Uses of Products.}

Charenal-Fuel, filtering, sumpowder, ete.

Gis-Fuel, illuminant.

Ammonia-Nedicine, hotisehold uses, chemical manufacture.

Woul alcolon-Denaturing alowhel, miline colos making, varnishes, burning, methylated ether, formalelehvile, etc.

Acctate of Iime-Dyeing, calion printins.

Murdints-1)yeing.

Acotates-Calico printing.

Acetio Acid-Chemical mamufacture. Se-called "Banana oil," at derivative from acetio aciel, is used in vanishes and paints.

Acone-Chloroform, iofoform, sulphonil, smokeless powder.

Chloroform-Anatesthetic, solvent for resins, ate.

Creosote-Antiseptic, meticine, preservation.

Tar-l'rotection of wood against decays; tar paper.

I'itch-Shipluilding, rowing, etc.

For smoking meats and fish, beech, wh and mahogany are chiefly used.

Putash is obtained by dissolving it ont of woul ishes, formerly almost the only source of this important rhemical. Putash is now prepared hy chomical processes from various materials. (Sio Potash salts.)

legetable matters, such as simdust, straw or hran, when heated with calustic potash, form oxalates, which on treatment with sulphuric atcid, riedel oxalic acid. This acid and its salt the usel chiefly in beaching and dyeinge. 


\section{GUMS AND RESINS.}

Gum ame resins are ustally formed by the drying of sap an reaching the air through fistures or incisions in the bark, or ly the transformation of plant tissucs. Some are obtained by artificial drying or distillation of sap. Many resinous extratetsare taken from barks, wods, or other parts of plants, usually by dissolving the soluble matter in water.

True sums form at mucilage with water and are insoluble in alcohol. They are chithy used in stifening silk and cotton falurics, in calico printing. in makins corliats and confectionery, in mucilage, printing ink, and medicines. Many ather substances are commonly called sums. such as resins, copals, rubler, camplure, lare, cte.

Resins are harder than wams, insoluble in water, and are mostly used in making ranishes by dissolving them in turpentine and linsecel oil or in spirits. Gum-resins are ustally fragrant and are thed for medicines and as incense.

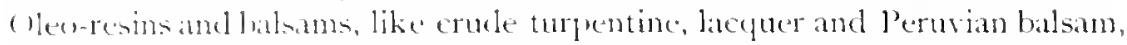
are thick liquids senerally whined by tappling trees and preparing the sap.

Gum Arabic is obtaincel from small thorny trees (. Iacia

GUM ARABIC mpecies) which wrow in chry samb olistricts in Arabia, Fypt Kordofan, and the aljacent country Gum senes.al is of somewhat inferior quality and comestrom smilar trees in northwest Afrieat in the region of the Senegal river. Gums, like gum arabic, are

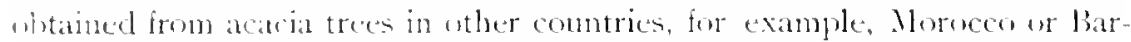
bury gum, Cape sum from South Africa, and Wattle gum from Australia. These gums, like most whers, are sorted over according to size, color, and purity and come on the market in different grades.

Dextrine is an artificial grum. (Sec. Dextrine.)

Gum Tragacanth comes from the stems of low thorny

GUM shrubs 1.tstragalus species/ which grow in Asia Minor,

TRAGACANTH Persia, Syria, and Armenta. The secretion of this gum is often increased ly the natives through injuring the bark. It in fomme on the market ustally an "flake tragacanth" in thin flat pieces, dull white in coldr. and marked with wary lines which shom the successive tho w the yum from the tree.

(Bums are obtained also from the meaguite tree (Prosopis species), in Mexicn, and aceasionally from cherry, peach, plum, and other fruit trees.

Gelatine, having much the some compusition and propertics

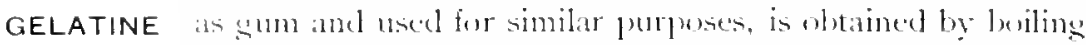
certain sea weeds. The most important sea-weed gelatine.

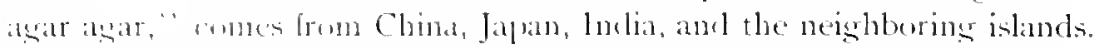

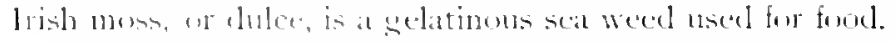

Other similat mucilagimous substances, getatines, and slues, are made

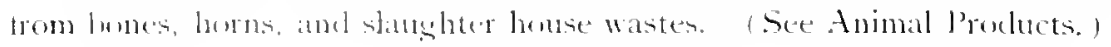

Copals are natural ham resins which arre foume in various parts of the work and are und in making vanishes. They ustally have to be melted or 


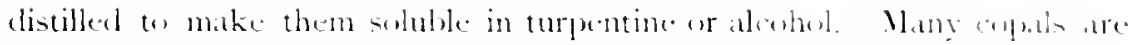
found in the earth, ustally at a depth of mot more than a few feet. in plates where extensive forests mere neren.

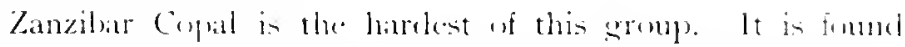

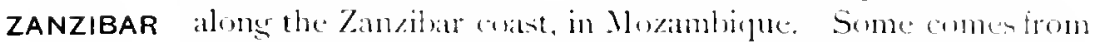
COPAL livingetrees? Trathlohime speries), but the harelest and best is the fossil variety which is dug from the gromml. Whan tirst dug, the resin is covereel with a sandy redelish crust, which is aither scraped uff, or dissolved away by a solution of serla or potath, learing the copal with a facetted surface, called the "worse-skin." This is charateristic of the best grades of Zamzil are cophal. Factories for the deaning amel washing of copal were formerly situated at Silem, Mass. wh that this grate is

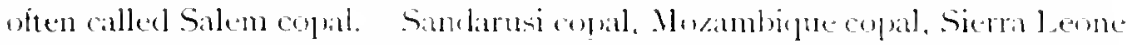

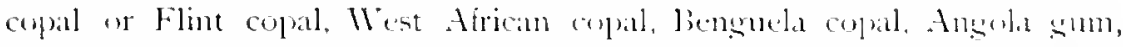

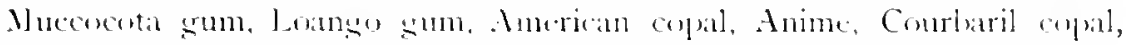
Acera copal, anel Manila cophl are nimes applied to similar resins if varying hardness from difierent lacialities.

Kanri Copal, or gum, is solter than Zimzibur copul. It

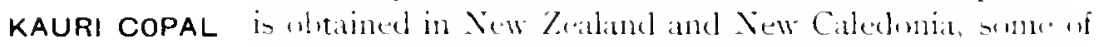
it from living trees (. Isathis species): but at mucl lareser

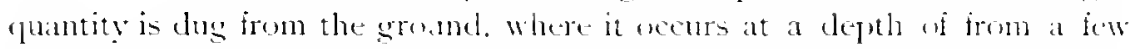
inches to ten feet. The lumps are ustally only an inch or two in diameter, lut some have been fomml weighing a hindrel pumbls. The tree which gielels this resin belongs to the pine lanily and attains a hedight of we to 100

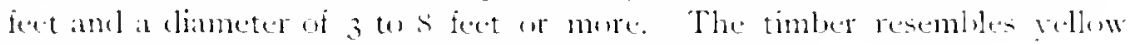
pine and in Xew Zealand is used for mamy purpones.

Gum Thammar indulen commercially several kinds of

GUM DAMMAR resins from suthe astern Asil. The true damniar comes from at tree ( Shored apecies) in Sumatra. Nixed with momentine it makes a very dear and valuable burnsh.

Sandarack resin from morthwest. Africa, amel Mastic from the shores of the Mediterranean, are similar in nature and are alos used in wornishes.

Benzoin is a fragrant resin from Siam, Java and Sumatra, used chiefly for incense.

Asafoetida is a gum-resin chlaincel in Afghanistin trom the roots of a

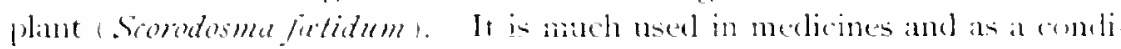
ment, especeially in II ureestershire sance.

Myrrh and Olibanum, of frankincense, are fratant gum-resins from Arabia used for incense and in melicine.

Gum ammoniacum is at shm-tenin used in medicine.

Aloes is the dried juice of artain plints the speciest used in merlicine.

Guiac or gum guatacum is a medicinal resin from the ligmum vitix tree.

Dragon's blood iv a rel remin uned in medicine and for vanish.

Kino is a dried juice used in tanning and tyemen. 
See Quebracho extrabt and other substances used in tamning and lycing. See lac, Shellac, Turpentiace, Rosin, etc. )

Japanese lacquer is obtained from the sap of a small tree (Khus ingicifere, the herries of which furnish wax. Varmishes having similar (fualities are mantactured by mixing turpentine with various resins.

Peru balsam, tohn lalsam, crpaiba balsam, and liquicl storax are all obtained from the saps of certain trees and are chiefly used in medicine.

Gamboge "1 "gummi gutti" is obtained in Camberlia by tapping trees (Garinia morelle) and collecting the yelow sap in joints of bamboo, where it harkens. It is used in medicine and in coloring varnishes and making water colors.

Rubber is an elastic substance produced from the milky juice

RUBBER of certain trees and vines which srow in tropical regions.

Nore than half of the world's supply of rubber comes from the valley of the Amazon river. Africa, the East Indies, Nexico, and Central America are the other chicf sources.

The most important rubber plants are the brazilian or Para rubber tree (Heta brasiliensis), the Central American rubber tree (Castilloa clastica), the East Inlian rubber tree (Fins clastica) and the rubber vines of Africa (Candolphia species).

"Rubber milk" is usually obtained by making incisions in the bark and catching the milky juice or "latex" in small cups as it flows out. It resembles cream in clensity and appearance and is composed essentially of globules of rubber floating in water. The globules are coagulated by processes which differ in various places. In Brazil the finest grade Para rubber is prepared ly pouring the latex on a stick or paddle and drying it over a smoky fire. As swon as the layer of rubber is dry, more milk is poured on, and another laycr formed, until the lump of rubber weighs several pounds. In other places the milk is allowed to dry on the trees or is coagulated by bolling, or by adling alcohol, sulphuric acicl, lemon juice, or salt water, or in one of many other ways. Rubber is graded commercially accorling to the country or district of origin and according to its quality. In the rrude state it usually contains much dirt, sand, gravel, bark, etc. For use it nust be cleaned by soltening, grinding, and washing. It is too solt and sticky for most purposes when pure, and is, therefore, mixed or compounded with various materials. When combined with a small per cent. of sulphur with the assistance of heat, it becomes "vulcanized" and is more chatic, kess soluble, and will stand more heat or cold without becoming sticky or mittle, than pure rubber. Reel rubler is vulcanized by heating the [rucle material with a sulphide of antimony. Lamp black is adeled in making black mbler. Hard rubber, ebonite, or vulcanite, is prepared by vulcanizing rubler with as much as 25 per cent. of sulphur, making it hard and horny. Substitutes and achulterants for rubler are made by heating oils, such as cotton, linsedel, rape, corn, or castor oil with sulphur. Rubber enters into the manufacture of almost innumerable substances, among which the following may lxe mutionel: soft or vulcanized rubber-bands, threads for 


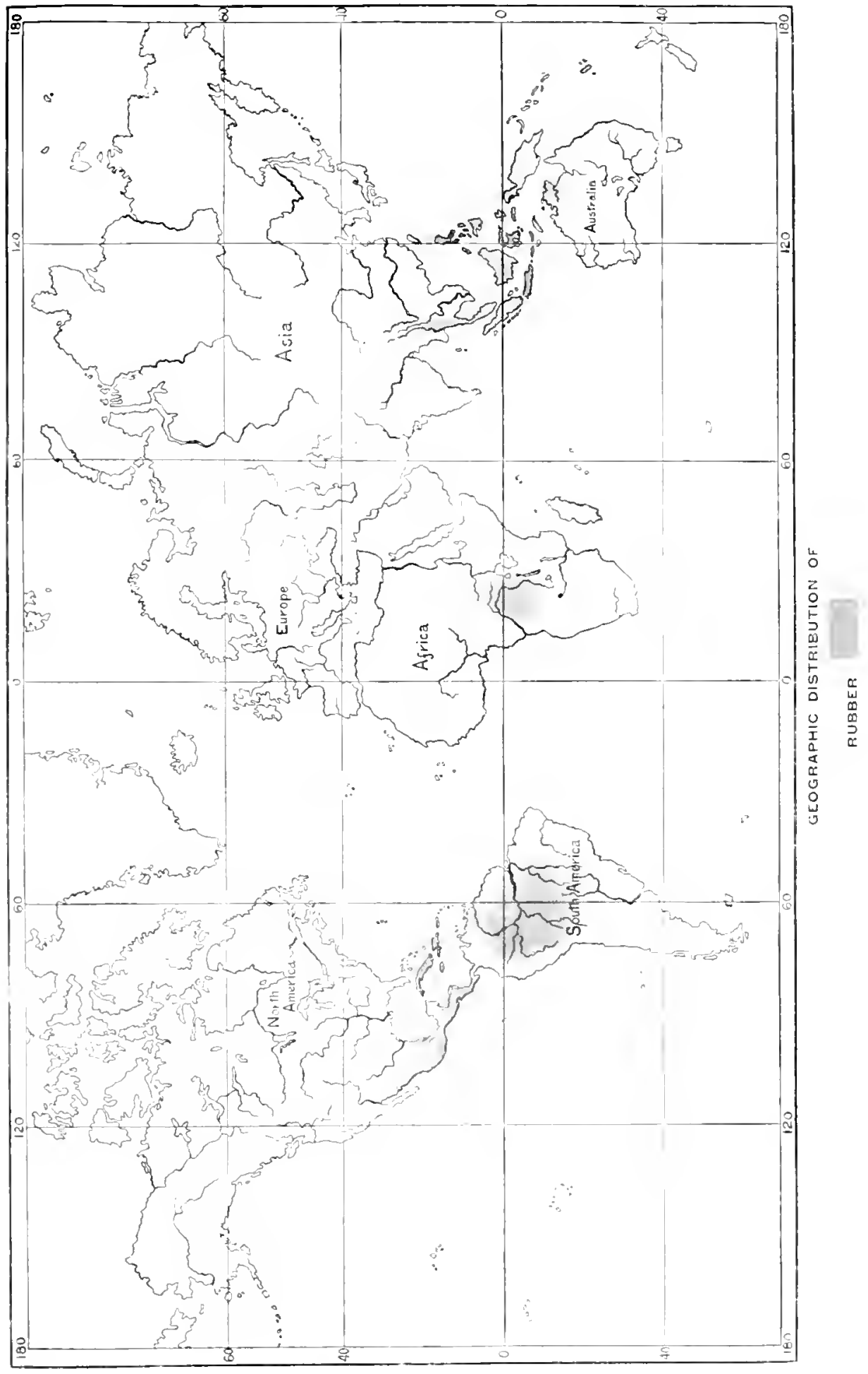





\section{OILS, FATS AND WAXES.}

The seeds and fruts if many plants ald rich in oil, this being the concentrated form in which nutriment is stored for the early growth of the young flant. Xearly all animats funsess fats capable of being renclered into ail and usually stored in the alrdominal cavity or in a layer under the skin. These oils are called fatty oils and differ from petroleum or other mineral bils and from essential oils in the face that they nay le siponified.

legetable crits are aldaincel by crushing the seeds by powerful machinery, thus pressing wut the oril and leaving ail cake behind. They are sometimes extracted ly disolving in cerlen bisulphicle or other chemicals.

oils are uner] for table purposes, for conking, stap making, Juluicating, ilhuminating, mixing paints and carnishes, in lyeing, in preparing skins and leatluers, in meelicine, and for other purposes.

bils are of two inportant kinds, drying oils, which, like linsed, evapwate and oxidize, forming a varnish-like sulstance, and mon-drying oils, like olve oil. Some oils (fats) like jalm oil, Japan wax, and tallow are solid at ordinary temperatures. For bulricating purpuses some non-drying oils are "hown" ly passing air through the heated oil, rendering it thicker and more visculus.

In sorat making, a fatty oil is heated and there is added to it a weak solution of alkali, such as caustic serla (Jye) or caustic jotash, which unites chembally with the oil, forming soly and slycerine. Soap being insolulbe in brine, silt is then arleled and the soap rises to the toip of the kettle, while the brine with the slycerine is chawn off from below. The soap is then furifed and usually mixed with coloring and scenting ingredicnts. Mineral matters, such as sand and pumice, are adeled in making seouring soaps. Roin can also le sapeniffed anel is much useel with wils in soap making, as are alsu certain waxes. Candles aremale from natural solid fats and waxes, and from prepared wils ly a process similar to what making.

Glyecrine is olstained as a lyeproduct in the manufacture of GLYCERINE staps and candles. It is used in phamacy, in various industrial procenese, and very largely in the manufacture of nitre-slyerine and dynamite.

(Hive (bil comes from comntries burlering the Merliteranean OLIVE OIL and in smal] amount [rom Itexicuand sunthern California. It is olstamed ly pressing the fruit of the olive tree (Oled

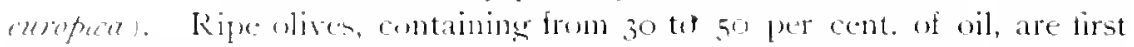
forsecel lishtly, yedeling a small amount of the best guality oil. Crushing the thesla with greater pressure yietels more oil, and a third pressure of the present cake after treatment with hot water, yickls an oil of poorer quality.

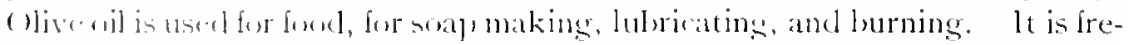
yuently andulterated with other oils such as cotton seed, peanut, sesane, ate.

Castore ()il is uhtaine from the secals of a plant (Ricimus

CASTOR OIL commmis, which grows throughout tropical comntrices.

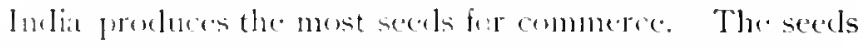
contain more than half their weight of wil, which is used in medicine. in the 


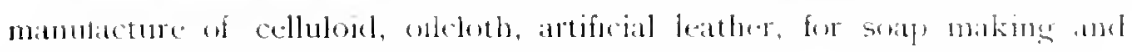

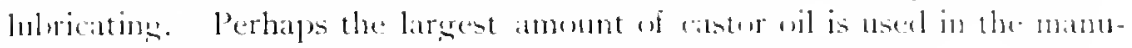
facture of textiles, especially for making "turkey red obl, " which is implosed for preparing cotton goods for lyeins with roal tar owhs.

Turkey Red oil is prepared hy treating castor oil with sulphurie TURKEY acid. lt is mnlike the original oil in being soluble in, or mixRED OIL ing reaclily with water. Olive oil or cottun oil is oftend used insteat of castor oil. fableses treated with turkey red , il ean be dyed with certain colors by which they are maffected before such treatment.

Peanut Oil is obtaned trom the common peanut 1 . Prathis PEANUT OIL hypogacal. The nuts, or serels, are raised extensively in West Arica and luelia and are pressed in France. The oil is used for soaj, making and ats a sulmitute for wlive wil. In making peanut lutter the nuts are simply nromol up, but not pressed.

Palm oil comes from West Africa and is obtained from the PALM OIL pulp, which aners the secels of the wil palm i Elaris suine-

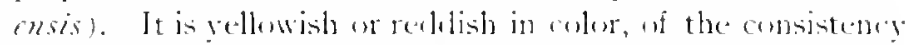
of butter, and is used for matking soap and ramelles, and for coating sheet irom in the manufacture of tin-plate. l'alm kernel oil is pressed from the kernels of the sime fruits.

Almond oil, rape oil, sesime oil, walunt ail, pelpy seed oil, suntlower oil, so bean wil, and veretalle tallew are a dew if the great number of other regetilile vils.

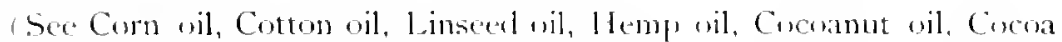
butter. See also Animal oils and l'etrolerim.,

\section{ESSENTIAL OILS.}

Essential Oils, or volatile ails, unlike the fitty oils do not form soap on treatmont with alkalis. They are obtained in small guantities from flowers, leaves, or other parts of plants usually ly clistillation with water. Some, like orange and lemon oil, are pressed from the rinels of fruits. These from flowers are altained by a pocess alled enflenrage which comsists in absorbing the

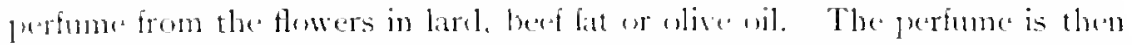
cxtracted from the fat or "pomade" hy solution in alcohen. Esisential oils are mostly used in perfumerv. for fionding, and in medicine. The best known examples of this gromp are turpentine and amplos. but these are not pepularly known as esentitial wils.

The following are important:-attar of renes, patchouli, wils w lavender, bergamot, bitter orange, bolet, geranium, tulnerese, bitter almonds, redar,

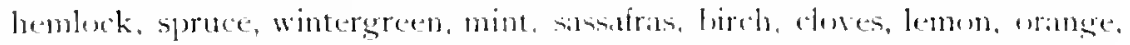
peppermint, citronellat, lemon stass, vetiver, antise, fennel, caraway, cumin, resemary, thyme, corbunder, womworl, ylung-ylang, sandal wood, cinnamon, bay, etc. 
Menthol, prodeced in Japan, is eleposited in ergstals on cooling oil of leppermint.

Witch-hizel extract, used medicinally, is olutaned by distilling young twigs of with hazel with dilute alcohol.

Musk and ambergris are animal substances used as perfumes.

()il of mirbane and other perfumes are obtained from conl tar, and many of these are ielentical in comperition and have the same odors as essential oils olotained directly from regetable substances.

Cimphor is strictly not a gum, but a solid volatile oil obtained

CAMPHOR from the wrul of the cimphor tree ( Cinnamomum camphora).

formosa is the source of nearly all of the camphor of commerce, althongh a little is olstaned from Jipan, China, and Borneo. To whtim campliner, the wool of the tree is cut up into small chips which are distilled with water. The camphor is condensed and later purified. It is useel in medicines, as a protection against inscets, and to a very large extent in the manulacture of celluloid and of smokeless powder.

(See Napthaline or tar camphor.)

\section{WAXES.}

Under waxes may be gromped beswax and all substances resembling it sufficiently to be used as substitutes for it. Cheap waxes are very commonly used to adulterate those of higher grade.

Sealing wax, shoemaker's wax, and grafting wax are prepared resinous substingees.

(See Becswax, Talhw, Spermaceti, and Paraffine.)

Myrtebery or baybery Wax is found coating the

MYRTLEBERRY lruits of sereral species of myrtle bushes (. Mryca) WAX indigenous to the United States, Central and South America, Cape Colony, etc. It is obtained lyy plunging the leeries in hot water and skimming off the wax which rises to the surface. It has a greenish color and al pleasant balsamic odor. It is chiety uned in combination with beeswax for making candles.

Japan Wax is a hard, wax-like fat obtained from the fruits

JAPAN WAX of several species of Rhus found growing in Japan (particularly Khus suciedance and a'enicifort, the tree which yick Japanese lac(uner). It is chietly used for the manufacture of candles, wax matches, waxed paper, and as a furniture polish. In Japan it is used to give a polish to cotton cloths, for making dolls and models, as well as for hubricating and soap making.

Viax forms a couting on the leaves of several palms.

Carnauba Wax, which comes from the under side of the leaves of a palm in Brazil, is ripidly graning in commercial importance.

Chinese Insect Wax, or pela wax, is secreted by an insect (Cocous peles amel deponited on twist. It is tseed in China for candles, for polishing wood and leather, and ats a sizing for payer and cottun soods. 


\section{DYESTUFFS.}

Commercial dres are either the extracte irom animal ar veretahle matter.

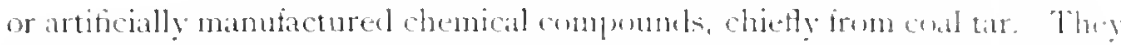
ate used for dyeing fibers, fabrics. wouls, leather, and feathers. The wreat

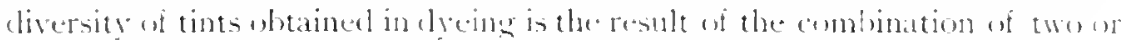
more substinces with one another or with certain chemical reagents. Tu renter colors permanent, the application of some chemical known as a mor

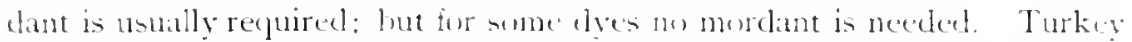

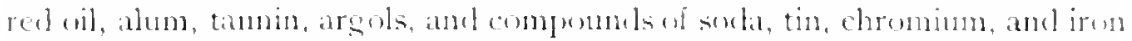
are the common mordants. Mlost vegetuble dyestuffs are handled commertcially in the form of extracts mas le by treateing the raw material with boiling water and evaporating the solution.

Indign is a blue elye obtained from the juice of the indige plants

INDIGO mostly Indigofera species which :2row in tropical comntries.

Inelia, Ceylon, Java, and Centrat Imerica are the chief producerts.

The freshly cut plants are solked in water, which alsorts the juice, becoming grecnish in color: on exposure to the ar it turns lilue, the indign separates, falls to the bottom of the tank and is tried. For dyeing indigu is usully acted on by some chemical such as sulia or putash. Which reduces it to a collorless substance known as " indien white." This is more easily sululle. than hlue indigo, and the materials to be dyed are dipped in a solution of this substance. Lion exponing the fabrices to atr. the indigo white changes atgin by oxidation to indign blue. In printing calicos, indigo white is thickencel with crum, dextrine, or starch.

"liluing " for laundry use is frepluently indiges.

The manufucture of artifial indigro from anal tar has made the growing of indigo unprotitable in the llet Indies and northern south Americi, where large quantitien were formerly probluced.

Valelder is a pumder made from the dried roots of a phant

MADDER A Rubia tinctorit, which is cultivated in suthern A-is and central Europe. It furnishes a red dye uset for cotton erouls, which is of decreasing importance wing to the use of coll tar colors.

Logwood or campeche is the lark reel heartwond of at thet

LOGWOOD (Hacmatoryton ampechanum, which grows in Central America and the Wrent lneties. Yucatan, Honduras, Hayti and Jamaicat are the principal commerebil sources.

The wonl comes to market in logs from five to ten inches in eliameder. from which the bark and sapiswel hate been removed. Logwond extrat is mate in the 11 est Indies as well as in America and Europe. This redelish coloring matter has mofinity for tibers and repuires the use of a mordunt. the color obtained depending w the nuthent used. It is largely employed for dyeing black, but gives also shates of blute gratg, and violet.

Brazil Wood, or Permanluce Mounl, comes from South

BRAZIL WOOD and Central America. As in logwind the heartmoul of

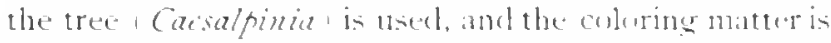
extracted with forling water. It wives shates of red and violet. but does nut alone produce fist colors. 
Fustic. mord, ar reflow would also known as ale fustic, is the

FUSTIC wood if another tree (Chophora tintoria) and is obtained in the Ilent Indies and tropicil Antericis. It is useal in dyeing woolen goods, giving a bright yellow color

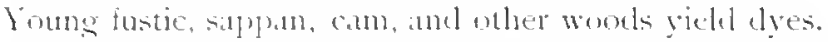

Quercitron is the wromel bark of the yellow-lark oak tree (Quoreus

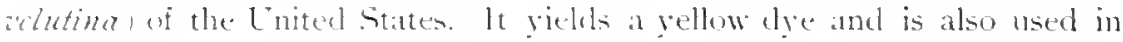
taming.

SAFFLOWER mus tintorius, which is yrown in many warm countries. Its production is important in Indial, Persia and Egypt. It is pumeded and mived with starch to make trilet rouge and its extract gives it reel dre fir silk

Annatu furnishes a harmless yellow dye used chiely in colorANNATTO ins butter and cheese. It is obtained from the pulp which surrounds the sects af a shrub (Biva arellana) cultivated in South and Contral Anurica and the West lndien. The pulp is washed from the seeds ly water, sepanated and dried. It comes on the market as a real or mange colored liguid or paste and atso in cakes. The dried seeds with pulp alloring are also exportcel.

Turmeric, turnole. rellow lerries or Persian berries, saffrom, hemna, wrehill, cutbers, and litmus are other vegetable dyestuff from roots, seceds, fowers, and liehenn.

See Cochineal, lac, cte. under Insect Proluets.

See also Coal Tar colors, Prussian Blue, Chrome Yellow, etc., under Mineral Protuets.

\section{TANNING MATERIALS.}

Tans include all suhstances which ly acting on the fiber of skins and hieles render them prof andinst the urdinary process of decay and at the same time nake them jlialle. Must of the vegetable substances used to convert skins and hickes inte leather contain an astringent principle called tamin. M.tny wher substances are used by tamners in preparine skins and leathers for market, such as line for unharing, acids, solium salts, ahum, doge's duner, birl's dung, lran, lampblack, oils, ege yolks, dyes, wamishes, cte. (see Tanning.

Nany sulstances, such as cutch and quercitron, are used hoth in tanning and in dreing.

The following. or extracts made from them, arc among the most inportant tans: hask-hemlock, wak, wattle, mangrove, harch, willuw: anodsoak, chestunt, quebrachu, gamhir, cutch; mats-myrobalans, valonia, divi-

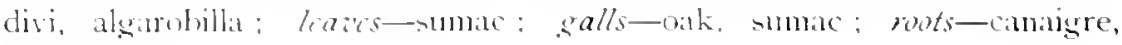
palmetto. 
Hemlock bark is the most inportant vectulle tombing TAN BARKS material in the I inited States.

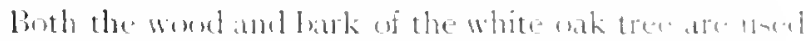

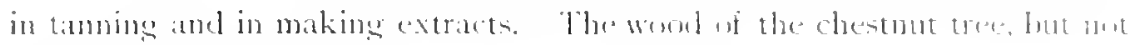
the lvirk, is alson used.

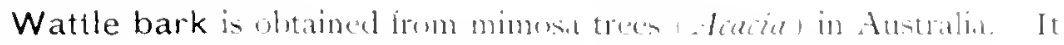

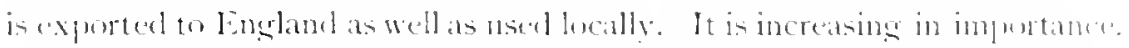
These trees rietd gums like gum arahe and furmish usetul womk

Mangrove bark is whatined fronn trees ( Khizophora) which wrow on swampy coasts throughout the trophes. It in used in mony placestor tomnime.

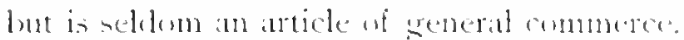

Sumac leaves are whaimed from different species of smatc

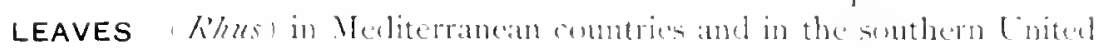
States. In semerat, the leasen from Eurepe are richer in tamnin. Sumac is uned for tanning fancy leathers.

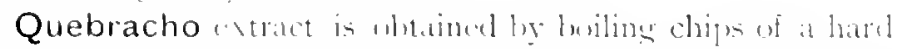

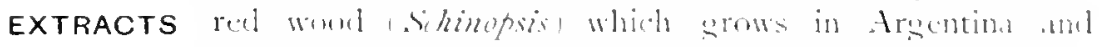
Paraguar. The extract is of increasing importume.

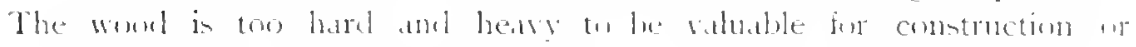
abinet wirk.

Cutch or catechu is extracted from the heartwool of an acacia trete common in India and Ceylon. It is nsed for lyedner and in tambing hedry leathers.

Gambier or terra japonica is a simblar extract coming trom lnthat amb

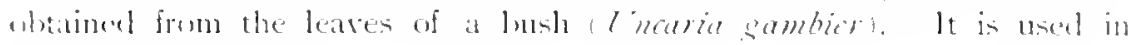
t.muning wift leather.

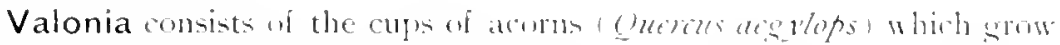
in the lecant. They are rich in tamnin.

Palmetto extract is make from the ruts and creeping stems of the sibu palmetur in the southern Lnited States. Sere Pulnetto fiber.

O.l Giallo are the prombet of small insects allied to the

OAK GALLS wasps and helmuing to the order //ymopter. These insect ratuse the hard werely abmormal growths upon the smaller branches and heaves of nat trees The female deposits an exre within the batk and the ting larval, hatching. feed on the soft wood. The inseet is supposed to secrete a stimulating how whirh angments the growth and causes the gall to form. When the larva antains its growth it changes to the pupa amithen to the perfect fly and cuts its way out of the gall. The commerial

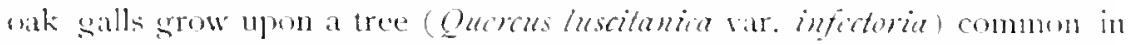
southwestern Asia. (The insect canse is Clmips quenens tinctoriat.) The lest galls come from Syria and Asia Niner and are exported from Aleppo. Galls contain gallic acid, closely allied to tamie aciel. They are used for tanning, and especially for making ink and dyes with salts of irom. There are other commercial and useful gill suming upon trees (Rhus scmialute

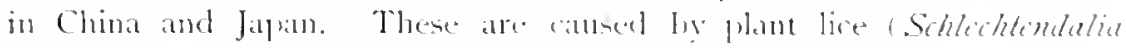
chinensis), insects belenging to the sultorder /homoptere. 


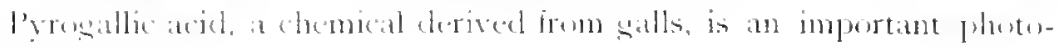
sraphic levelenet.

\section{MISCELLANEOUS SUBSTANCES.}

Aruels are tepenited as a crestalline conting in calsks of youme ARgOLs wine. They are called lees, and consist of cruke potassium

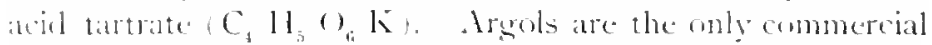

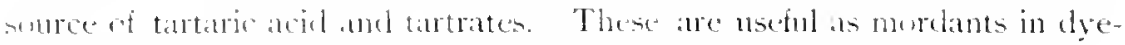
ing, and ralice printing, in making baking poweler, crean of tartar,

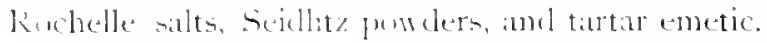

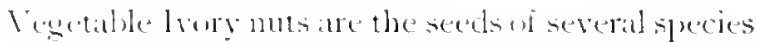
VEGETABLE IVORY of palm trees. The kind most commonly used (Phitilifhas matocaper come from Ecuador and

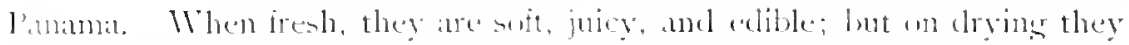
lenome hard. On solking in water they hecome soft enough to be cut with

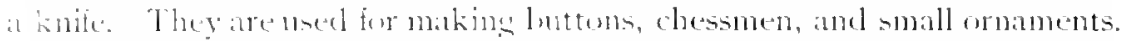

Lycopodium pmoler comsints of the minute spores of certain species of chl, mosese common in Europe. It is useel in making fireworks and by Histrmacists.

Soap bark and soap berries are collected in various countries. The

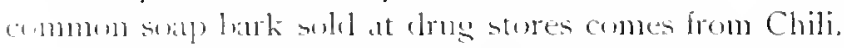

Teasels are the dried heats of a common plant and are grown in

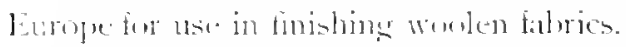

Pyrethrum, a substance used in insect powders, consists of the poudercel flowers of phunts allied to the chrysinthemum. It is abtained Ahichly from I almatia, Persia and southeastem Emope.

There are many other vegetatile materials in common use, some of which enter into generit commere.

\section{ANIMAL PRODUCTS.}

Animal l'roductin may le comenicntly dassified as follows:

Live animals for brasts of Inten, for slaughtering, for breeding, tc.

Articles of Animal Origin used for Food:-Meats, fresh, dried, salted, cammel, or otherwise preserved, from attle, shecp, swine, fowls, solmo, etr. : meat extracts, fish, wsters, crabs, lobsters, eggs, milk, butter, che ese, direl, aleomargarine, selatine, ete.

Animal Fibers:-Hair, wool, fur, Iristles, silk.

Hides and Skins:-Furs, mw hides, leathers, feathers.

Horns, Hoofs, etc., inchulins irery, tortoise shell, whe.

Animal Oils:-lintter, larel, rut liver oil, fish ril, etc.

Pearl and Mother of Pearl, Sponges, Corals.

Other Products, inchuling perfumes, e.t., Mhsk, civet.

Insect Products (xher thin silk), inchuling honey, wax, cochineal, lac, walls.

In the following prosen these are sromped according to the animals which protuce them. 


\section{HORSES}

Horses are raised in almost all parts of the world, chiefly as beants if burden. In the United States the preatest mumber of horses are ratised in the senth and west; some are exported for loreding, raving and draft pus-

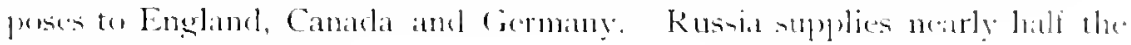
horses useal in linrope.

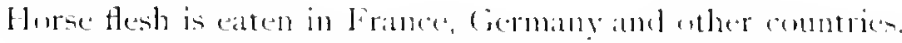

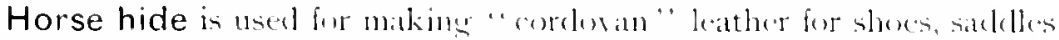

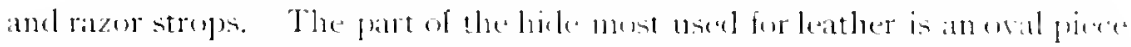

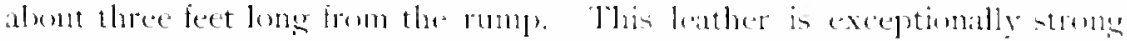
and more nearly waterprone than that from any other land anmal. It is fmished in tan, black and inther colers.

Horse hair from manes and tails andes an the muthet from Rusial,

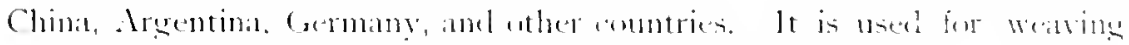
in hair choth. for making bouhes, and for bens for musical instruments. When outed it is unel for stuffing mattresces and furniture.

I'rmented mare's milk, "koumiss," is impunted from western Ang for

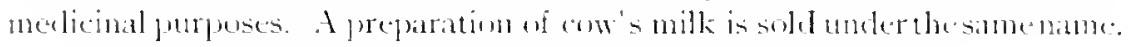

Moles and asses are more used thatu hereses in many places.

\section{CATTLE.}

Coltle are rased in all prats of the worlel and are important corerywhere in heal commeree. The Inited Stiztes, Russia, India. Areentinat, Cermany, Austria-Humgary, Finace and Australia are the greatest cante raising countries. The Enited States, Argentina and Australiat are the enteatlest experters.

live cattle are shipped from ane place to another chielly to supply fresh meat to distant points. Breeds of cattle, as of other animals, differ

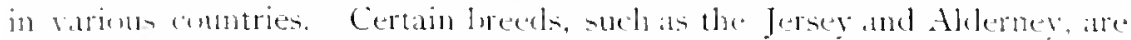
mont valuable for milk; whers are better leet catte. The humped catte af

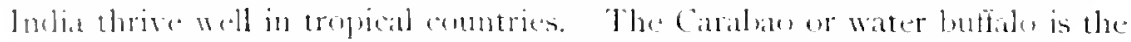
principal alraft animal and leatst of lumelen in many Pacific Islands. In

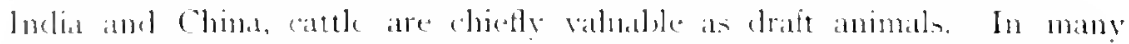

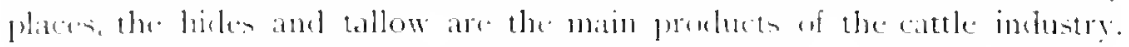

Iilk, lutter, cheese, buttermilk and comelensed milk are valuable commeroidly in nearly all countries.

sugar of milk is used medicinally and in silvering mirross.

Slanghtering ame meat packing are important inclustries in the

BEEF Initud States, Europe Arsentind and Mustralia. Chicage, Kansis City, St. Louis and (monalud are the mest important centers in this commery. The expot of live cattle is less importint than it was a few bars and, beciuse so much meat is now shipped in refrigr rator cars and in the cold storage compartments of stamships. In adelition the the fresh meats shipged, large amounts are dried, salted, comed. smoked, canned, or wher wise preserved, or made inte soupse and estratets. The by-prouluets of

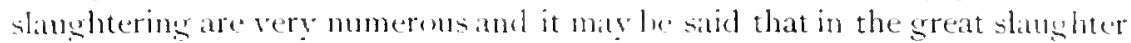
honses 130 part of the animal is wasted. 
Cow Hair. The long hair trom the tails is used like home hair. The

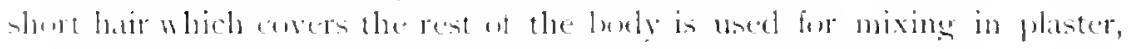
and making rowing felt.

Horns and hemfs of cattle are ntilizel in making combs, luttons, $10 \mathrm{~m}$ hedla, knife and other hambles amb hancy articles, atso in the rhemical mannfucture of eymicle of putall.

Bones are useal in making loutwons, combs, loundles for tooth brushes and wher articles, wten as a sulstitute for ivory. The waste from bone manufarture is burnt, forming lwne chareol of lome black, which is used in filters for bil and susur, and in making blacking. The srease extracted from hones is used in sonp and candle making. Some ammonia is recorered in hurning hones.

Tallow is made from the fat or suet of cattle or sheep by melting and straining it, a process which is known as "remlering." It is used for soup and candle making, for lubricating, and in dressing skins and leathers. The purified rils and fats are used in fibricating butter substitutes, such as iheomarearine and butterine. These, like real butter, are usually colored with annattu.

Neat's Foot Oil is marle by boiling the feet of cattle and skimming off the wil as it comes to the surlace. It is a viluable lubricant.

Gelatine is male from the feet of cattle and from hide cuttings and sincus. Calf's foot jelly is mate by boiling the feet. Hides are treated with lye amb then boiled in water, dissolving the gelatine, which sets on cooling amel is cut into sheets to dry.

Glue is similar to sclatine in nature, but is ustually male from bones by softening them with hycholshoric acid and then steaming them. The glue and bone hat are drawn off from time to time and separated in settling tanks. licjuicl glues are macle by dissolving ordinary glue in weak acids.

Size is used in preparing paper and fabrics and is smilar to ghe and nelatine.

Dried Blood is used in purifying sugar, clarifying wines, in dyeing, and in fertilizers. The albumen of blood is employed in calico printing and as a morlant in dyeing.

The Intestines of cattle supply goldbeater's skin, sausage skins, etc. bialders cleaned and prepared, on account of their thinness and strength, are used by druggists and oil dealers as coverings for vessels.

Pepsin, renmet, and other substances are prepared from the lining of the stomach and certain other parts.

Fertilizers are mate from all the waste and reluse parts of the animal, and from the coltings and waste from bones, horns and hides.

Hides are known to the tanner accorcling to the age of the animal, as "hicles" frum full grown cattle, "kips" from two year old animals and "calf skius."

Rawhide is simply the lried and cleaned skin from which the hair hats been remored, softemel he oils. It is used for ropes and lariats, for belts and bett lacings, whips, and faces for mallets. 


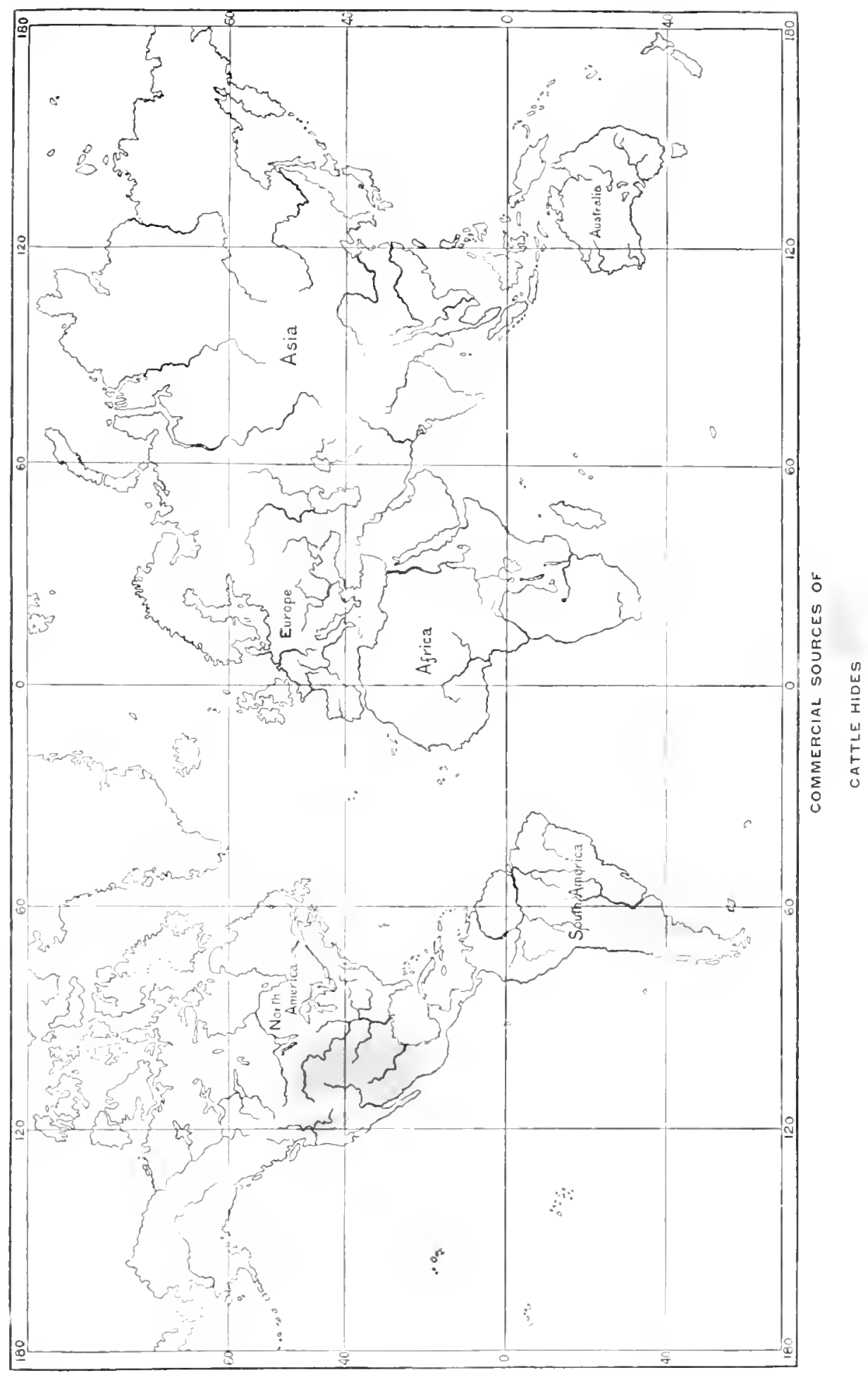



Vellum is mate hom call skin hy moharing with lime and then whthing it down with thalk and punice.

\section{TANNING.}

When hicles are received at the factory, they are cirher fresh from the

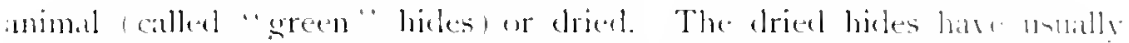

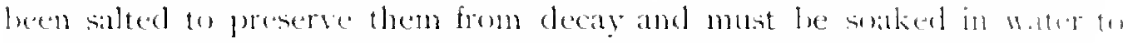

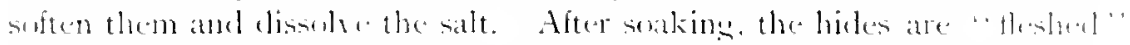

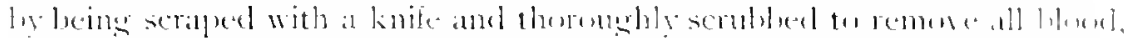

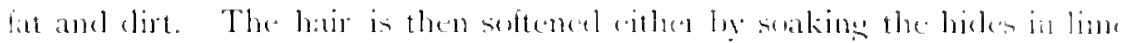

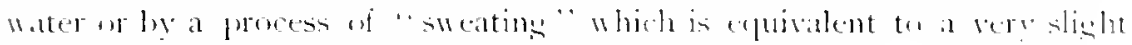
decay. In either case the hair is remored, semerally ly a mathine, and the hides are then ready to he tamed.

In tamning sole-leather, the hide is solked for sererol

SOLE LEATHER days in vats. first in a wak solution and flenen in a stromerer liefuor, made by steephing oak ar bemlerk bark in water or ly dissohing prepared tamnimg extrats. This aluses a

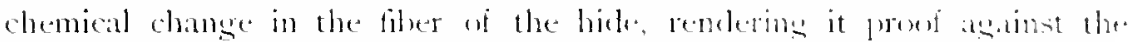
ordinary pocess of tecay to which the untannerl skin is liable, anel making it pliable instead of hard and stiff, as hieles are when simply dricel without tanning. The tan-liguse is mate stronger from time to time, and the hides are frepuently "handled" ar moved abmut, so that they will come. in contact with fresh licpur. After five as six months, or somedime afere 1

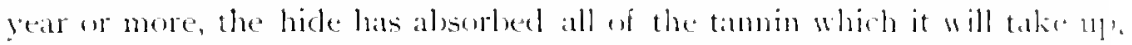
and the tanning is complete. The hides alre then remosed from the "pits,"

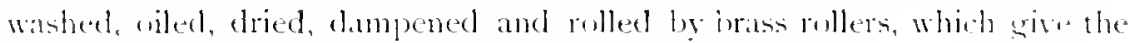
kattien at aloss on the hair side.

Other grates of leather are tanmed and tinishod by UPPER AND variations on the above process. Thick hicken ase

FANCY LEATHER often split thin ly machinery and the flats fetanned and finshed separately. The parts from the hair side are most ralualile and are called "grain" leather, and the inner

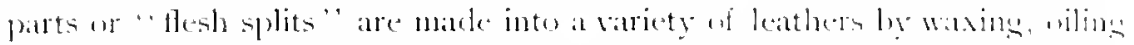

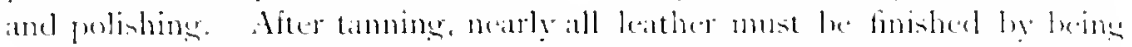

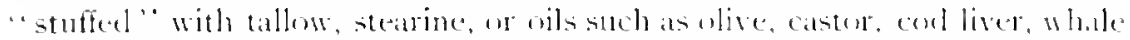
"1r sperm, and polished by rubling with brushes and rollers. Patent and enamelled leathers are crated with black vamish.

leathers for different purjuses are mate from the hieles of different

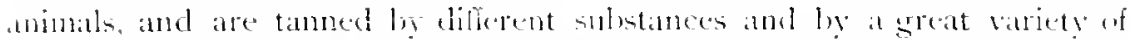
processes. Croat skins are tammed in larese numbers for soft she leathes realled "glazed kid" and other names) by immersing them, after prelim

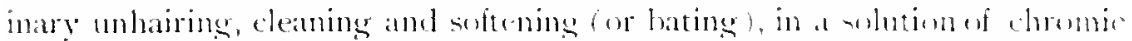
acid, bichromate of potash or ahm, and then in a bath of sedium hypusul

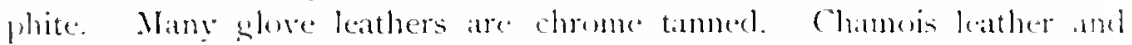
wash leathers ane made of sheep skin hy thoroughly impregnating it with

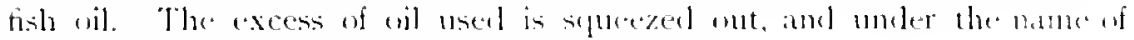
"degras" is used in currying wher leathers. 


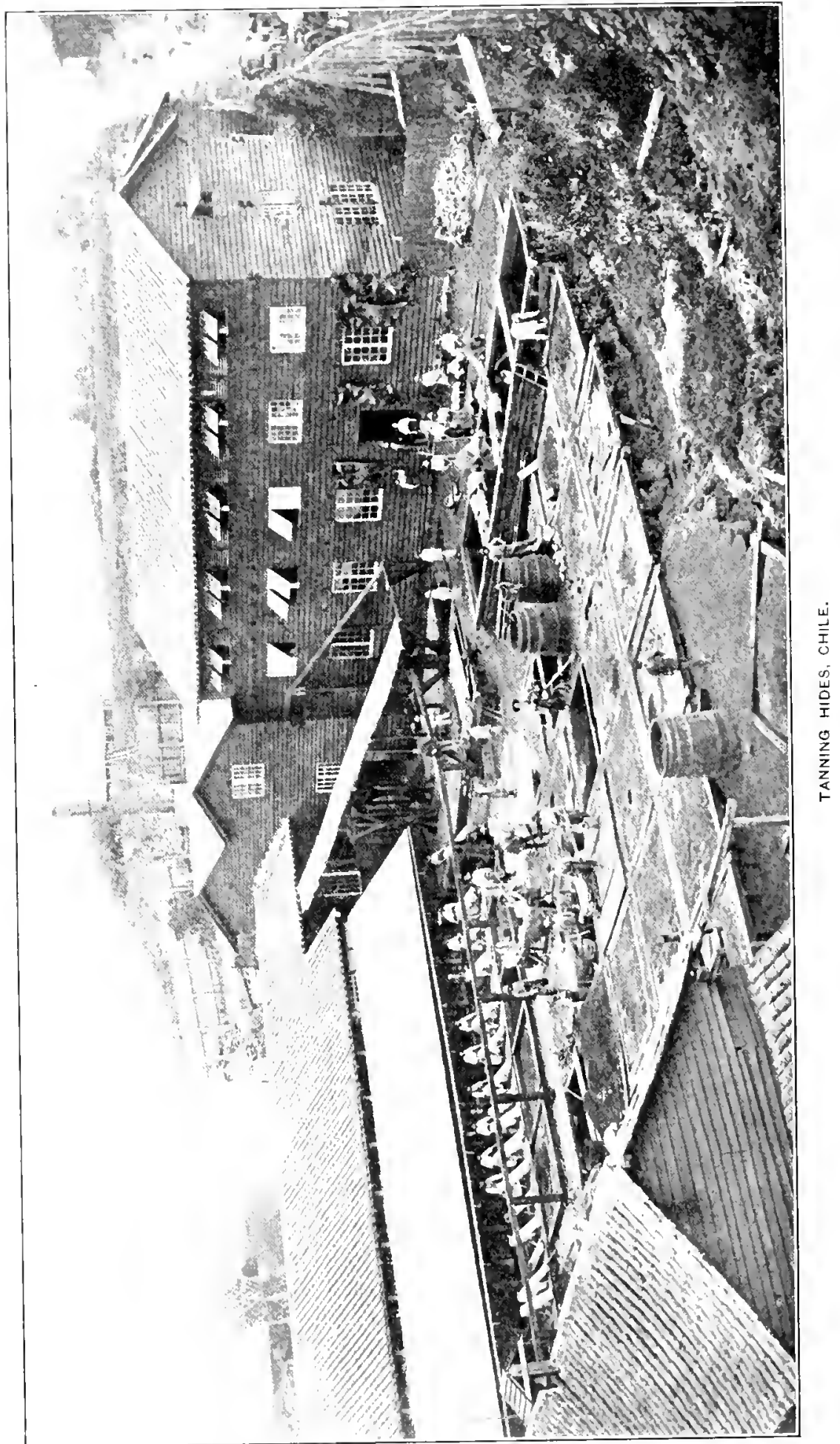




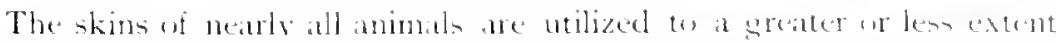
when tamed or dressed. Calf skin makes a soft beather for lumb and shotes. Lamb skin, dos skin, deer skin, buck skin, doe skin and rat skin the uad

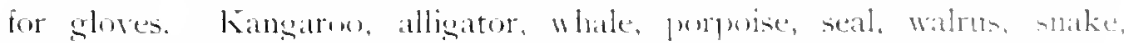
beatrer tail, and hundreds of other skins are nsed in making fancy loathers, for hand bags, purses, feelts and miscellaneous articles.

There are quite a mumber of materials sold at innitation

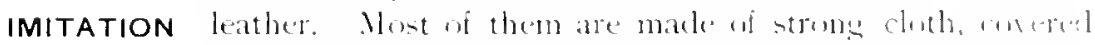

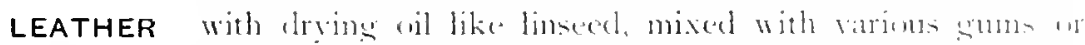
other solid substances. The exact compunition is unatly

kept secret by the manufacturers. Imitation bathers are uned for almont all purposes for which leather is used, exrept for shoes and shives.

\section{SWINE.}

The United States is the sreatest hor rasing comntry. Large mumbers are raised in Germany, Austria and Russia, as well as in nearly all other parts of the work. Live hogs are sehom expented. Pork is a rery im. portant food and is eiten almost everyhere except by Jews and Mohammedans. Chicago, Kinsas City and Omaha are the chief centers uf pork packing. The meat is sold fresh (refrigerated), salted, pickled. smoked. and in the form of ham, bacon and sansige.

Lard is one of the main products. It is the rentered fat of the

LARD hog. Its dhef use is as a food stufi. Lard oil is oftanded ly. placing hard in woolen lates and submitting it to heary pressure.

It is used for lubricating and lighting and as an adulterant for other oils. Stearine for candle making remains after the oil is pressed from larel.

All parts of the hog are utilized. The hair is sill for mixing in mortar, the intestines when deand are used for sausige calsings, the homes are carbunized and sold to sugar refiners, or with all uher refuse are mate into fertilizer.

Pigskins are made into leather for saddles and satchels.

bristles are obtained eommercially, chiefly from Russia and

BRISTLES China. In these comntrien the pirs is much like its ancestor the wild boar and has not reen improved lybrecting. The bristles of these animals are much more valuable than those of the improved breeds raised in America and are used for making brushos for many purposes.

\section{SHEEP.}

Sheep are raised throughout the temperate parts of the ghobe. Anstralia. Arecontina. Eruguay, Russia and the r nited States are the kating shede

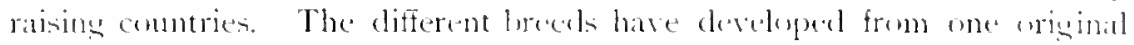
steck and are due ter differenees in climate and find and to selectim in hreetings. Some breeds, like the southown. ate most valuable for

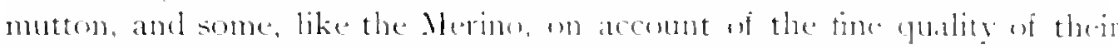
word, and in these respects eath lued differs somewhat irom the others. 


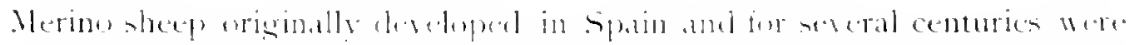

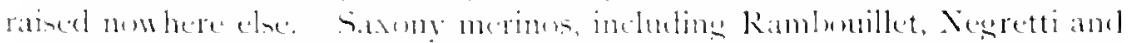

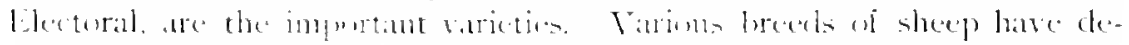

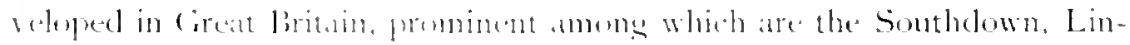

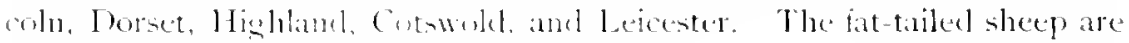
peruliar to contain parts of Ania and Aricik.

Live Sheep an expred from Arentina. Conited States. Canada, Australia and New Zeahand.

Mutton is mot so large an item as either lece or pork in the

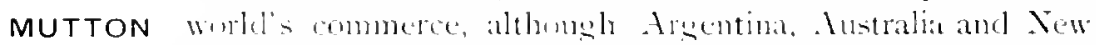
Zealunel ship many fromen carcasses of sheep and lambs to Engime. The thesh of theep is sethom eaten in span exeept by the reryon.

Sheep's milk is used in France to make semune Renuefort cheese.

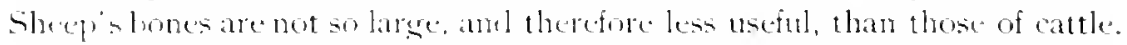
Tallow is remelered from the fat of sheep as well as from that of cattle.

Cat Gut used for strings for musical instruments, tennis racquets, and wher purpones in mearly all prepared from the intestines of sheep.

Sheep stins are dressed for use as rugs by treating the

SHEEP SKINS flesh sicle with powdered salt and alum. They are also employed in some parts of the world for clothing. Fashionable furs are mate of the skins of unborn and very young lambs ancl aceording to the beed of the animal and the part of the world from which they come, they are known as l'ersian lamb, broaltail. Spanish Astrakhan, Thilet, etc.

The worl is shaved off from the skins of sheep which have been slanglitered. and the skins themselves, called " roans," are used for making leather. See Tamning. They are often split so as to set leather of even thickmes and the two parts tamed separately. The pieces from the hair or "srain" sick are called "skivers," and those from the flesh side, which are if porer quality are called "Aleshers."

Whercos and colored leathers are tanned and finished by different preceses and are used for many purposes, such as linings in bents and shoes,

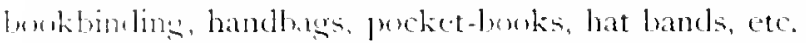

Chamos leather is meade ly dressing sheep skins with tish oil. Gloves are make of lombskins dressed with oil to imitate kid, deerskin and dong skin. Parchment is made of shecp skin (sometimes of goat skin) by serapring and rubling flown with challe and pumice.

Wind is the most important animal fiber and the most valuable

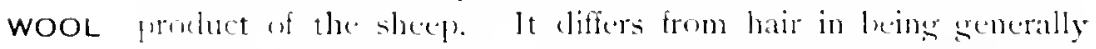
fine and in having a strface which under the microsenpe is seen to be covered with a wreat mumber of minute overlapping scales. The surface of hair sometimes shows acales, lut they are few in number and much lens prominent than an wom. These scalen with their projecting edeses, give

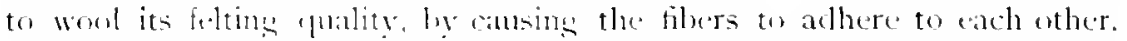

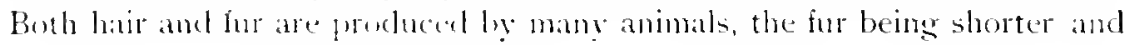




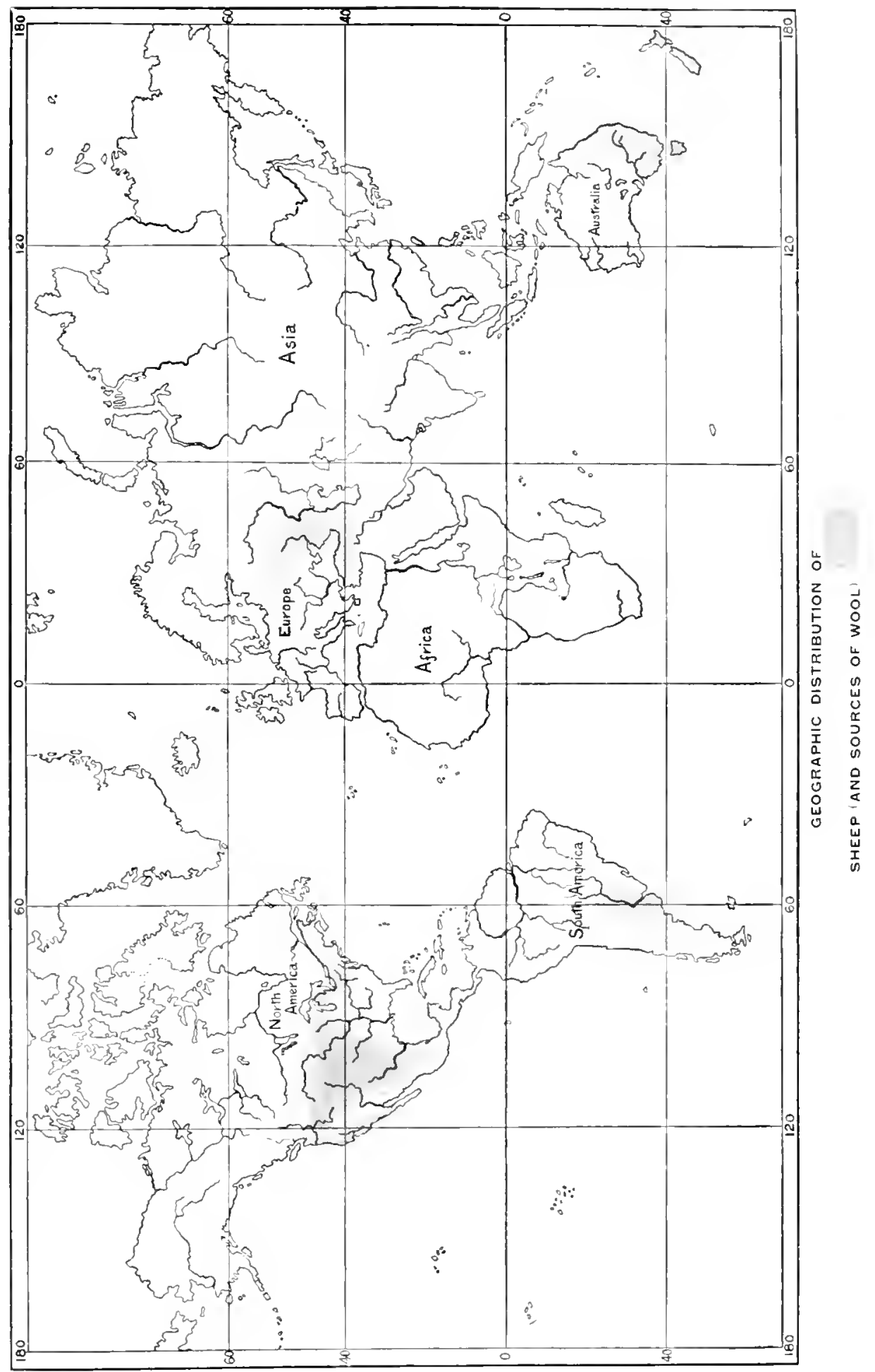




$$
\text { - }
$$




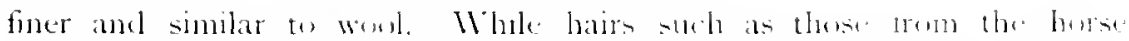
and cow are straight, the wewl of the Nerimn shecp in beantitully waty and

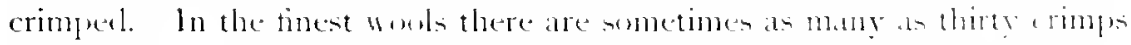

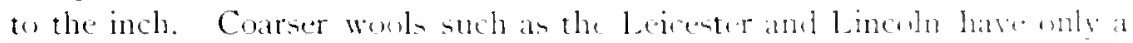
few crimps in an inch. There are sereat clifferences in the length at titer w

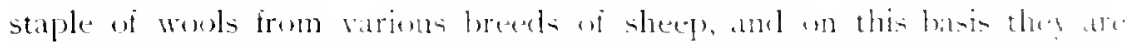

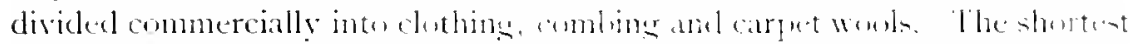

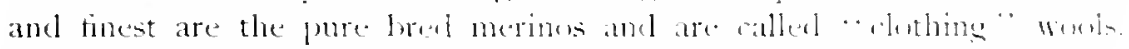

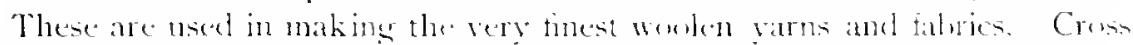

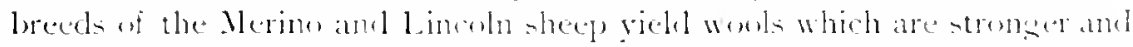

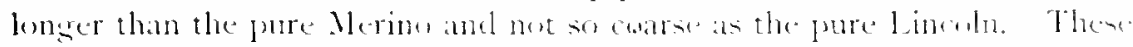

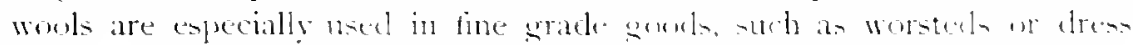

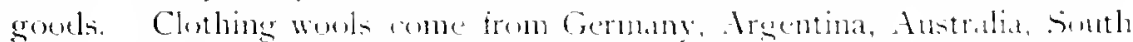
Africa. Russia and the Enited States. The longent and conarsest af the grood wools are such as those of the Linown and levester loneds and are called "combing" wouls. These are used in making worsted yoms and labrics. for carpets and blankets. England, Sostiand, France, Auntralich, and the Enited States supply most of these wonls. Lamb's wol is used with certain furs in hat making.

In Ruswia, Asia Mlinur. China and Spain there are lare numbers of sheep which have undergone no improvement by mixture with the lincoln or Nerino breeds. These are called native sheep, and they produce "native" or "carpet" womb. The wowl of sheep as it grows, is saturated with a natural grease ealled wom lat. yolk or stant. This causes the wow to shed water ant prevents it from tangling or felting on the sheepliakle. Where it is abundant in the woxl it also causes dirt to stick, and for this reatum many

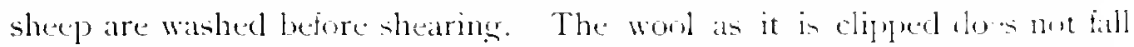
apurt like bunches of hair, lut holds together like a skin, and is rolled "up and tied in a bundle, each fleace by itself. When the theeces menpened they are spread out and serted inte several grates, according the tength and fineness of the fiber, because the wol on some purts of the sheep's boxly is of better quality than on wher parts. The wouls from the poree breeds of sheep are not sorted inte as many granles ats the finer wols. and the fleeces of the poorest kinds de not hold tugether in the form of a stin.

After sorting or "stipling." the woen is "sconted" ly washing with soap and water to remose the errease, potash and dirt. In sonuring some very greasy dirty wook lowe at much as so per cent of their weight, the grease jtself not infrequently lecing aser 60 per cent. The wow fat is by some processes saved and sold as lamoline, or converted into soap. In the next presess, "earbonizing," the senured wool is treated with acid, which destrogs all burrs or other regetalle matters which are tangled in the flecece.

The next step is w comvert the woul inte yarn. For this purpme it must be "carded," if it is to he matele intw a woolen varn. or it must be "combed," if it is to be made inter a worsted yarn. In arding the wom is passed over a cylincler set with inmumerable fine wire teeth which serve to tangle the fibers in all directions, after which it is louscly spon into worlen 
yarn which, in turn, is woven into worden gomols. The wool used for woulen

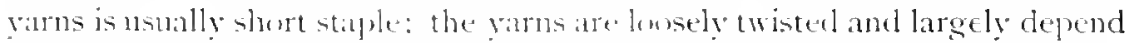
for their coherence upun the feiting property of the wool. For worsted yarns the worl is comberl, in oreler to lay the separate filuers prallel to each nher, after which it is spm into vom, usually with a tighter twist than that

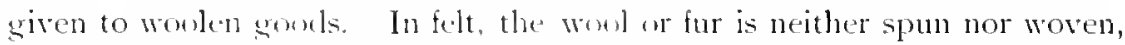
but is simply tangled and pressed, or kneated or ponnded. The scales with which wol and fur are beset greatly facilitate the felting process, and the more numerous the scales, the more readily will the wool or fur felt. Naterials which, like vegetable finers and silk, lack these scales, will not felt at all.

In all of the processes of making wool into yarn and coth there are portions consisting of short, broken or tangled fibers which lo not pass through the machines. These are termed "waste." The best grades of waste are mixed with goonl woll in yarns, or else spun with "shoddy." Shoddy is made by tearing up old woolen gools, rags or cloth cuttings in a machine until the falyric and the yarn of which it was made are reduced to a mass of loose fibers. It is mixed with wool in the manufacture of cheap yarns and fabrics.

There are many falmics on the market made of woul, some of the most important of which are woolen, worsted, felt, flannel, serge, broadcloth, cheviot, cassimere, carpets, tapestry, blankets, hosiery, underwear, shawls, velvets and plushes. IVoolen fabrics are often arlulterated with cotton, and there are many mixed goots woven with warp threats of cotton or silk and weft of wool, or vice versa. Carpets frequently have a warp or a backing made of jute, hemp, linen or cotton.

\section{GOATS.}

Goats are raised in large numbers throughout western Asia, particularly in Asia Minor. There are many in the mountainous parts of southern Europe and northern Africa and in Mexico and Texas. In some countries they are used as beasts of burden.

There are several distinct varjeties of goats (Caprus species) such as the common soat, the Angora and the Cashmere, and among these there are numerous breeds.

Goat's flesh is eaten in many places, that of the kicl heing most highly estecmed, hut in civilized countries it is not a popular article of diet. The meat of the Angora goat is said to be equal to mutton. The tallow is used for making candies and the largest horns like those of deer.

Croat's nilk is in common use among the Arabs and in Italy, Spain and other Mecliterranean countries, as well as in Cuba. It is customary where this leverage is 1sed, to drive a flock of goats about the streets of a city and milk the animal at a customer's liwr. 


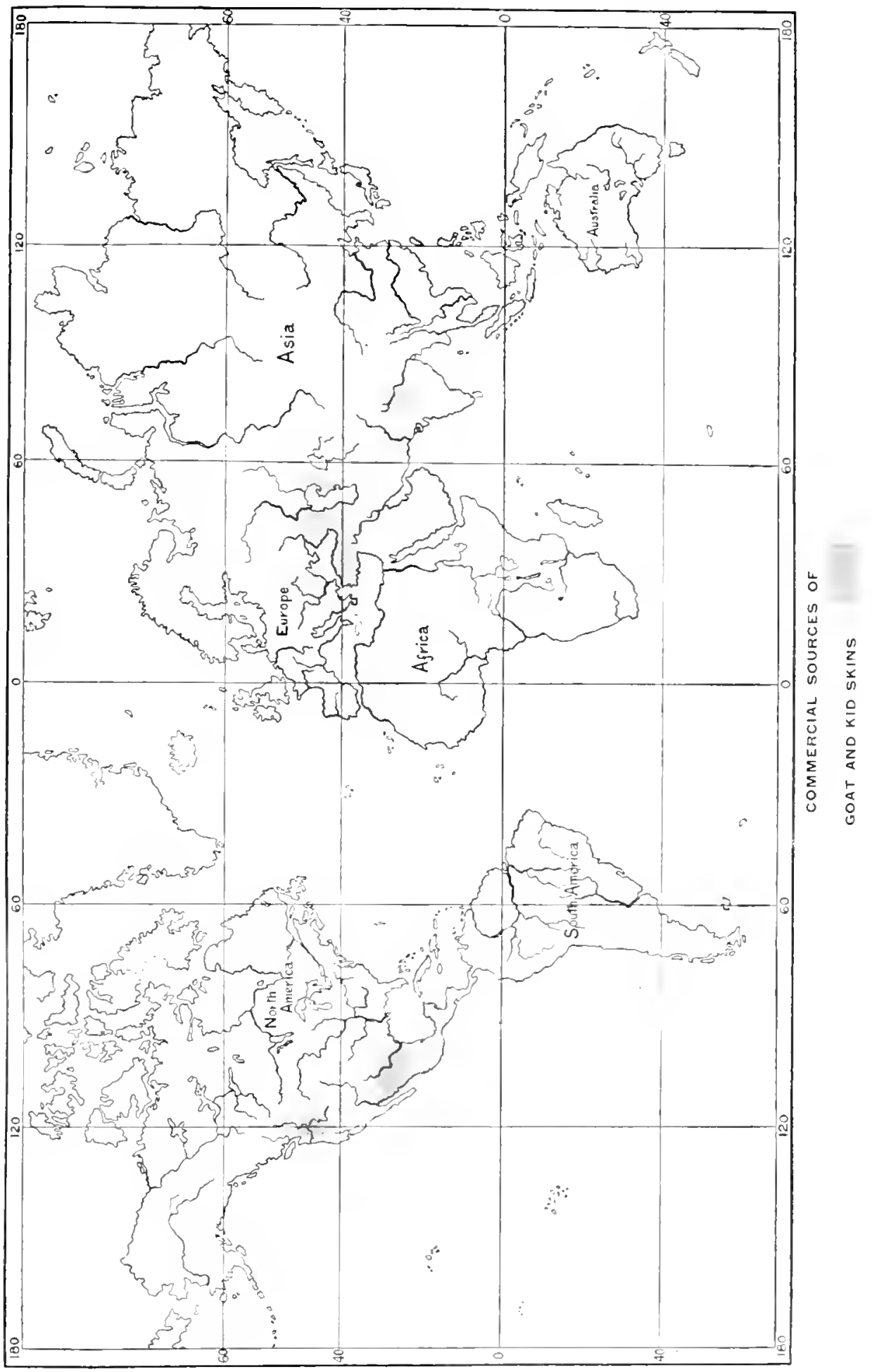




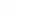


Goat skins are used liy. Moors and Arates for making bottles

GOAT SKINS to hold water and wine and for making morocos leather. Some skins, particularly surh as the Angeras, are used for rugs and in parts of the world for clothing. In the Lnited States and Eurne very large numbers of goat skins are imported for leather making. Sie Taming.)

Glazed kid and other soft leathers for shoes are made of goat skins tanned with chrome. Iornoco and lancy leathers are mate lor bowktholing, shoes, and miscellaneous articles by tanning with sumac or other vegetable tans. Much morneco is macle also of sheep skin.

The original cordovan and moroco leathers were made in Syjan and northern Alrica of goat skins.

Kid skins are made into glove leather by " tawing," a process in which, after thorough soltening, the damp skins are tunilled about in a drum containing alum and salt, and then after drying are tumbled again in another drum with a mixture of oil, flour and exur yolk. Glove leathers are also made of sheep, lamb, deer, rat and other skins.

Goat hair, as it is known commercially, conses from the

GOAT HAIR common goat. It is obtained in Turkey, Russia, Asia Ninor and India. It is ustally from three to four and a half inches long and white, red or black in color. It is used in making coarse blankets and carpets.

Angora or Mohair comes from the Angora gaot and is produced in South Africa, Turkey and the United States. It has a very gloss fiber often ten inches in length and is used in making dress woods, braids and plushes.

Cashmere wool is produced in Thibet and the high-

CASHMERE WOOL lands uf central Asia by the Cashmere grat. This animal has a tine soft wool and lomere coarser hair. The wool is used in making true Cashmere shawls, which are very highly valued on account of their beauty and durability. Nost goods commonly sold as cashmere are made of sheep's wool.

\section{CAMELS.}

The camel produces a fine wool which is especially suited CAMEL HAIR for making hosiery, melerwer and shawls. It is also employed in making fine lrushes. At certain seasons of the year the hair of the camel lousens and is plucked out by hand.

In China, Arabia and other parts of Asia, Russia, Turkey and many parts of Africa the camel is a common treast of lurelen. It flesh is freculuently eaten, its skin tanned, and its milk used as a bererage or made into cheese.

There are two important varieties, the two-humped or Bactrian camel and the one-humped camel or dromedary. 


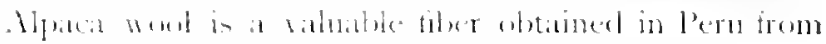
ALPACA WOOL the alprica, an animal of the camel triluc. This woul is

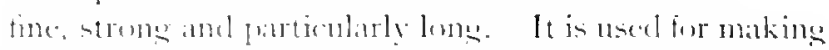

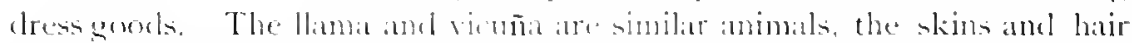

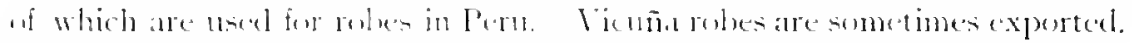

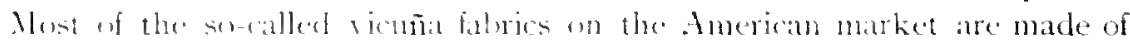

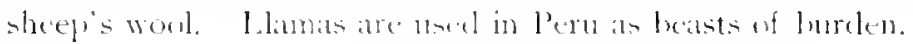

\section{MISCELLANEOUS ANIMALS.}

Deer and antelnde of many species furnish foud and rothing in DEER some districts. The reindeer is the rivef armestic anmal in the

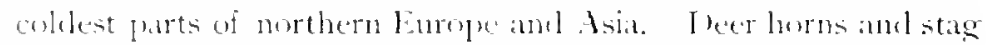
homs are used for ormanents and in the menufucture of knife handles and varins fancy articles, and are obtained in India, Ceylon, Siam, China, Russia. Cremany, Africa, Canada and Central Ancrica. Deer skins are used for ruse and in leather making, chietly for buck skin and lowe skin.

lrory is abtained chiefly from the tusks of the elephant, in India

IVORY anel in . Arica. It is used for funcy carrings, lilliard balls, linife handles, piane keys, combs and vacine proints. The Indian elephant rlisplats much intelligence amel is trained as a beast of burden. Elephant"s hiele has been tamed, but this leather is not witen used. Small amounts of ivory one from the tusks of mammotho dus up in Sil reria where they lived in [ust ases, from hippoprotimus teeth, narwhel horns, and the teeth of the wallus. Walrus skin is tamed to make a fincy leather.

Mest if the valuable furs of commere come from the cold countries

FURS if the northern hemisphere, with the exeption of the skins of monkeysund of the cat family. Lontonamb leipzin are the great fur markets. In addition to the furs used in Eurepe and America for mats, robes, mufts and other clothing, commous numbers are sold in the colder parts of Asiatic Russia and China. Here there is a market not only for costly furs hut also for large numbers of cheap furs which in America are not strlish. Sa oter is probally the most expensive fur in the world, a single skin luing sometines worth $\$ 1,20 n$. Russian sable and silver fox, while costly, are more common.

Wikt animals of the cat family furnish many skins for rugs and ornamental purposes. Prominent among these are the tiger, fim, leopart, funther. lynx and wild cat. Skink of the demestir calt, when dressed and dyext, are commonly worn as furs under various names.

Skins if chess are also used in fur russ and rubes, and leather from the hicle in male inte gloves. The Eskimo doe is most inportint as a dramght animal, and dogs are used similarly in Beleinm and other parts of Europe. Wolf skins are used principally for knapsacks. low skins are amons the most pepular furs, the common red fox furnishing most of the shins used. The skin of the silver sray fox is rery valualele, lecing worth up to $\$ 200$.

Skins of hears, rateonms, wolverines, skunks, martuns, weasels, crmines, minks, siblen, monkers, moles, chinchillats, utters, lualuers, nutrias, musk

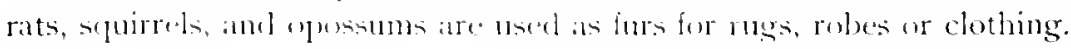




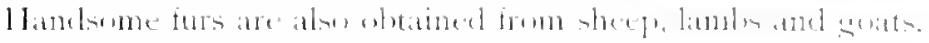

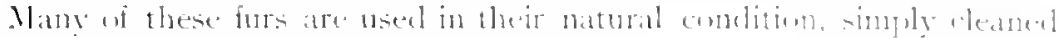

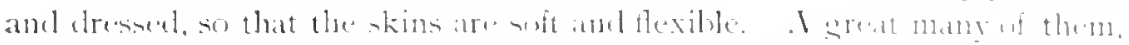

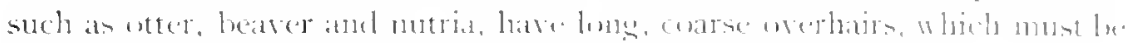

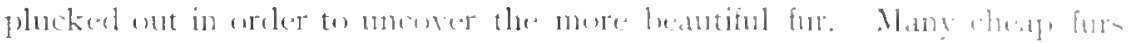

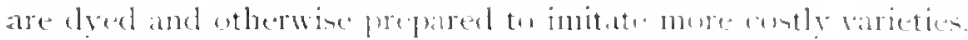

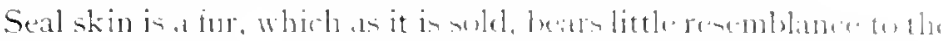

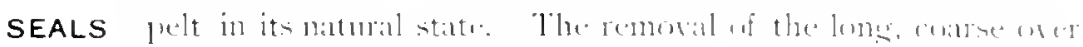

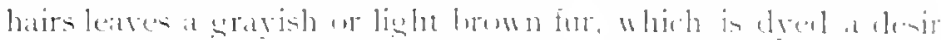

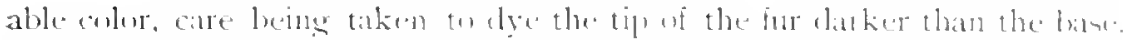

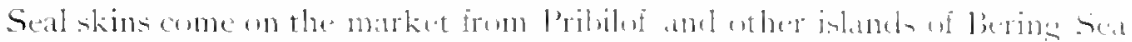

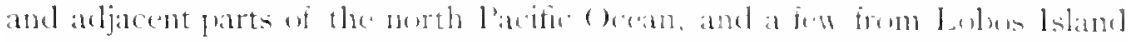

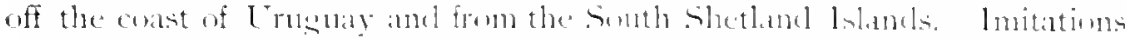

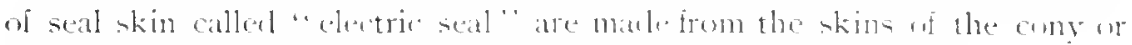
European rablut, and cheaprer imitations still, we simply plushes.

In atdition to the bur seal, there are sereral othere kinch of seals, such as the har seal and the harp heal. The skins of these and the sking of sea lions are used for makiug seal loather.

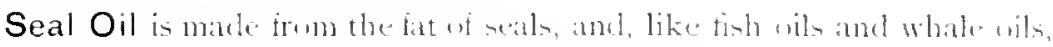
is used for leather dressing, lubricating and burning.

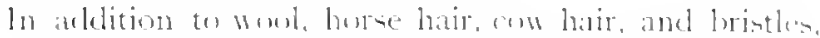
ANIMAL HAIRS the hairs of a viriety of inimals find inclustrial atglian-

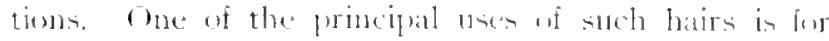

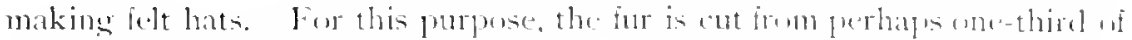

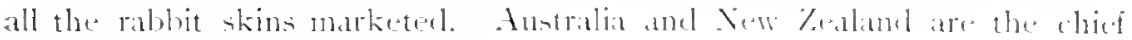
comntries supplying bahlut skins.

The nutria or cogpu furnishes a larese percentage of the fur used hor hat

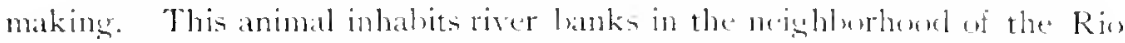
de la l'lata, in South America. Its fur is corerel with comse hairs which are first removed. When prepared, the fur withe nutria resembles that wi the otter. and is sometimes sold as such.

Clippings from muskrat, beaver, seal, otter and mink skins by manuiacturers of clothing are solel to hat-makers, who cut off the fur and use it for lelting.

Badger hair is chietly used in shaving hrushes.

The Musk Deer inhabits the mountains of India, China, Thibet

musk and siberia and fumishes a very important perfume, musk, from a small sac in the buly of the male animal. Sime other animat. such as the musk rat and musk ax, produce a similar substance.

The civet cats uf Arica and . Lia supply a similar perfumse.

The heaver yielshe from a small sate in its budy, a meedicinal sulntance known as castoreum.

Ambergris see Whalen). 
Whales if several species furmish artickes of commercial value.

WHALES The Cirecnland whale finhery is now the most important.

Whale oil or "train" ",il is obtaine from the blubber or fat of whales, usually by cutting up the blublere and allowing the oil to drip) out, It is then heated and straineel. It comes in three grades, "spring." "summer" and "winter" wil. The best is winter sperm, from which the solicl wax or spermaceti has depositer on conling. Whale oil is extensively. used in leather dressing, in the preparation of manila repe, for burning and soay making. The best grates of sperm oil are employed for lubricating light machinery ancl in the recoil of large camon.

Spermaceti is a wax which wccurs chicty in the head carities and (held in solution by sperm oil) in the blubber of the sperm whale. It is used in candle making, in pharmacy and for waxing cartridge covers.

Whalebone is olstaned from the mouth of the whale and is not bone, but a substance in its nature similar to hair. In the upper jaw whales have a series of long plates hanging from the roof of the mouth, with bristly fringes an each sicle of the tongue. These fringed plates are the whalebone or balcen. Whaldome is used for stiffening in corsets and dresses, for whips and canes and for making brushes. It is sometimes split fine and woven into silk somels to stiffen it and make it rustle.

Ambergris is a lrigrant substance formed in the intestines of the sperm whale. It is used as a basis for perfumes and commands a rery high price.

Sperm whales have teeth in their lower jaws which are sometimes used as a sulstitute for jrory.

Porpoise leather is made by tanning the skins of the white whale.

Tortoise shell consists of plates from the back of the

TORTOISE SHELL hawk's bill turtle. This animal is captured in warm waters in many parts of the world. The so-called shell is used chicfly. For combs and is much imitated in celluloid. The eggs and Hesh of the green turtle are used for food.

Sponges are obtained commercially along the shores of the

SPONGES Mediterranean from Sicily and Alseria, eastward, and on the shoses of the Bahamas, Cula and other VTest India islands. They are the cleaned skeletons of certain peculiar animals (Spongidac) which reacmle plants and grow attached to rocks, shells or corals in tropical Waters. In life, the sponges are covered with the soft grelatinous body of the amimal, which is frepuently beautifully colured and delicatedy formed. The spmeses are oltained either by dredging or diving; the gelatinous parts, which som decompose, are washed off, and the cleaned sponges bleached, and finally washed in a weak solution of glycerine to prevent them from lecoming loritte. Spunges are of many different shapes, sizes and qualities. Some animels of this family have steletons which instead of being soft, absorbent and elastic, are laard and brittle. These are not commercially valualile. 


\section{FISH.}

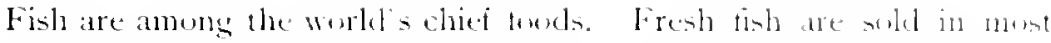

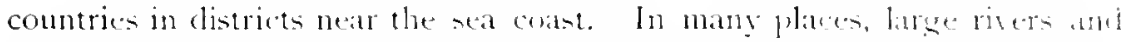
lakes supply consiclerable amounts of tish to the aljowent combly The

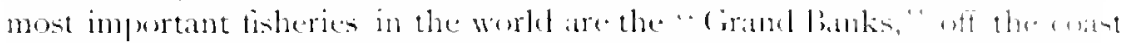

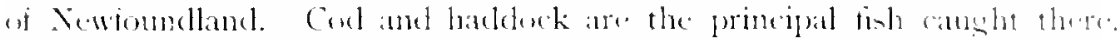

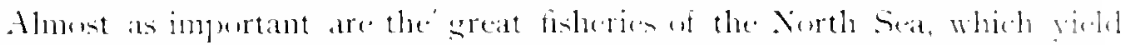

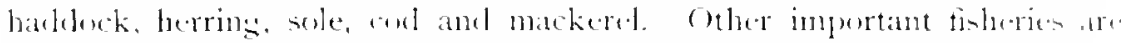
along the coasts of the mothern Athutio and l'acifie eneans. The inherien of the consts amb rivers of Chima supply a rery lange quantity of foum.

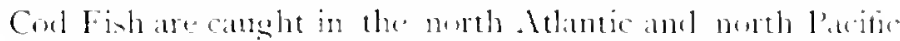

COD FISH werans. They are musty salted and lried, and find an enor mons sate in Roman Catholic comptries of Eumpe Centual and South Americat and the Whet luelies. The esponts are chietly irom Norwas. Newfoundland, Canade and the Enited States

Cod liver oil is whamed by heating the livers of the and thsh. The lest

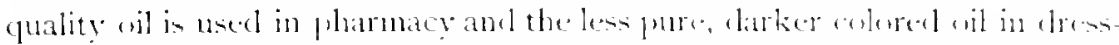

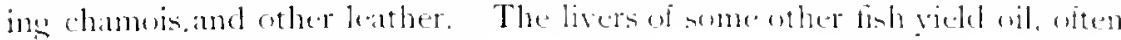
solel under the name of cond oil.

Salmon are cambht in arcatest numbers in the rivers on the

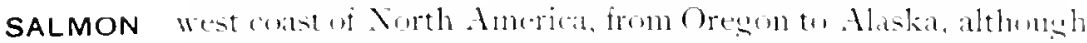
many are taken in Japan, Sileria and Xomay. Most of them are canned, althewh some are refrigerated and shipled to eastern punt

Herring are taken in the morth Atlantic and are -illed,

HERRING prickled or smoked fon market. In Maine small herrings atre packed in wil and come on the market a soldines.

Sardines are caught in the Mediterranean and on the Athantic couts of Portugal, Spain and France.

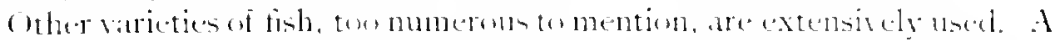

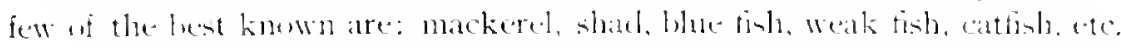

The cuttle fish supplies a secretion from which true sepial pigment is

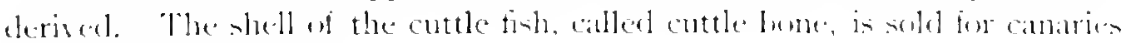
and other cased hircts.

Caviare in the prepared amel salted roe of sturgeons. It is mate on the shores of the Casplian and Black Seats, the Creat Lakes. Delaware biay anel some wher places.

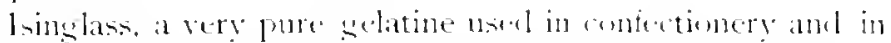

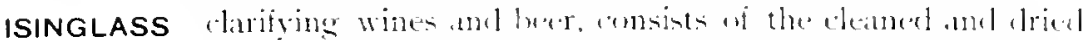

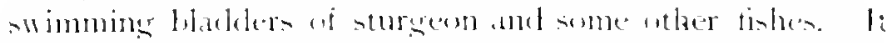
is imitated in sedatine obtaned trom wher somen. The name ininglans

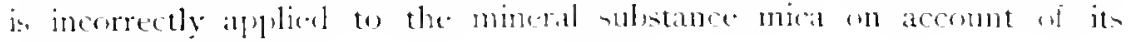
similar alpearance.

Beche de mer, trepangs, or holethurians, are popular in China for making soup. 'These animals, wten called seal cucumbers w sea slugh, are captureel and dried in large numbers on the comal rects borkering the islinds adjacent to southeastern Ania. 


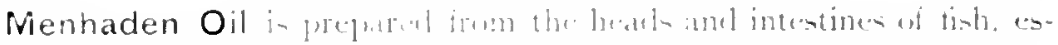

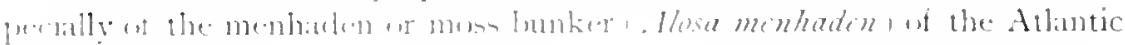

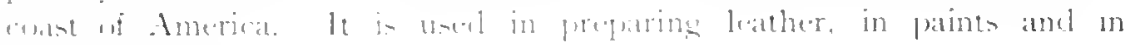
wiling rup.

Fertilizers are preparel irom the refise of fiste canneries and in some

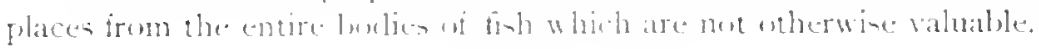

\section{SHELL FISH.}

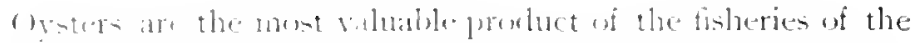

OYSTERS [nited staltes. Mire than hall of all produced in this

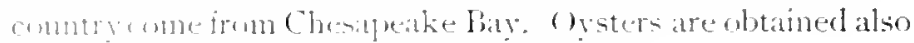

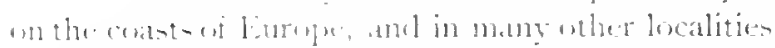

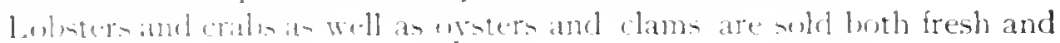
canmerl.

PEARL OYSTERS fearlo ind mother-effeatl. These shells are found wif the rasts of Ceylom, the Snciety Istands, the Intimus of Panama, and in the Gulf of Califurnia, the Red Sea and the Per-

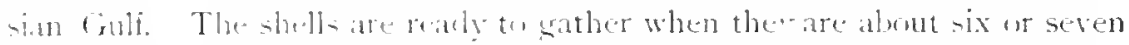
years ald. Coreat carr is takion wh leave the younger shells undisturbed. Fent are formed ly matter which the animal sectetes to cover up eratus of

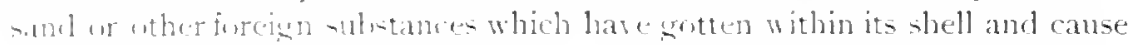
irritation, or at the randt of divease. The best pearls and best mother-of-

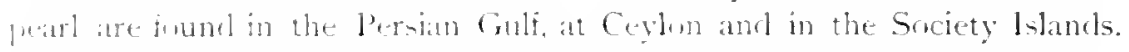

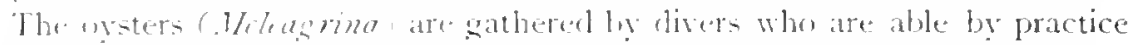
tor remain under the water for a minute and a half tw two minutes at a time. Pearls are unerl an jewel. Nother-of-pearl is used for knife handles, ornamentu, luttons, inlis work, etc.

The frell-water mustels are used tosome extent as mother-of-pearl and lave been known to produce fine pearls.

The Alalone (llatiotis) shell comes principally from the shores of the I'acific and supplice a very loilliant mother-of-pearl.

Shells if nther kinds are used for cutting cameos. Snails are used in wime remutrites for fousl.

Corals are robtained in many places and are solel as curiosities. Red coral. chiefly from the Indian Ocean, is used in jewelry.

\section{INSECTS.}

The silk of commerce is obtained from the coconns of several species SILK of insects. In these species, the caterpillars (or worms) form their cocurns of an unbroken strand of silk which is secreted by the insect in its lowly as a jelly-likts smbstance. This harlens on exposure to the air as the worn forese it wat and winels it about its body. The common silk worm (bomber mor) is not a wild insert, but is reared in cultivation ex-

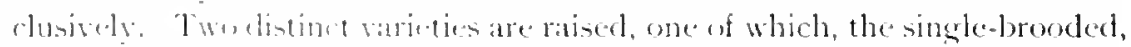

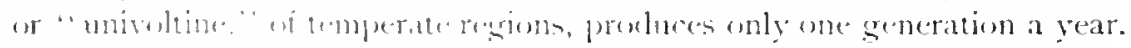

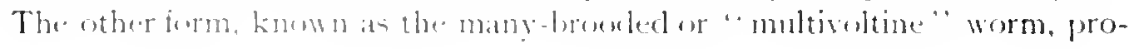




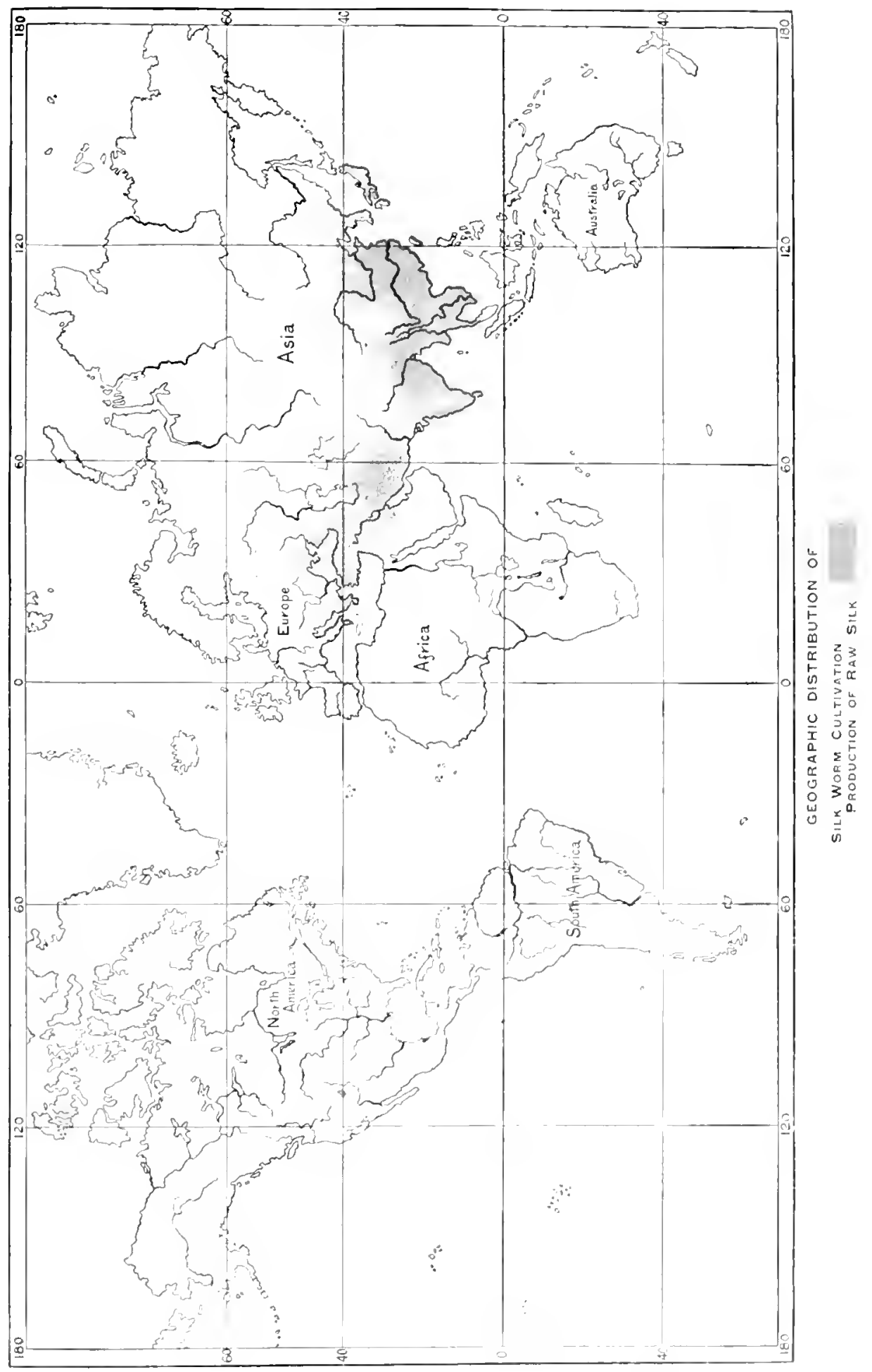




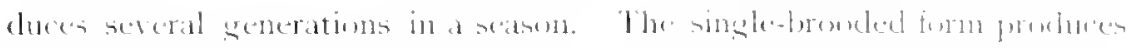

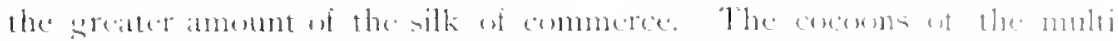

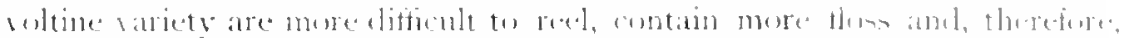

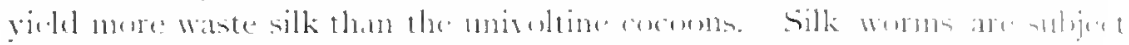

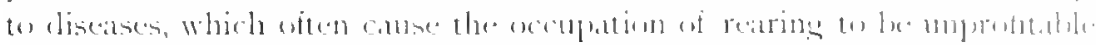

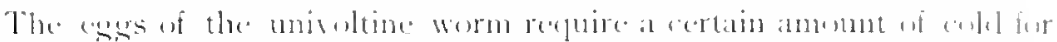
their healthy hatehing. After the rege hatch, the youme wome are ted on

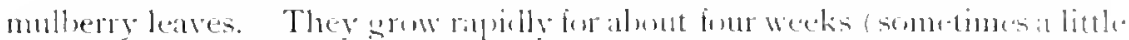
longer) during which time they shed theif skin (or monte four times. Whan

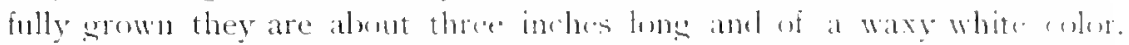

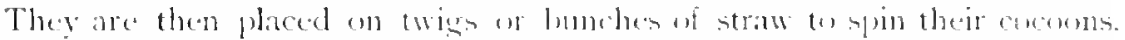

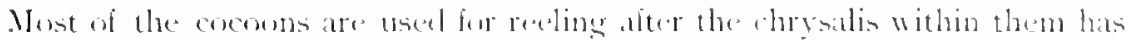

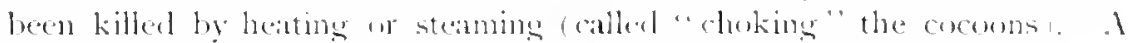
sufficient number of coconne are geserved for the moths to emerese from, so that mure enges can be procured.

The common silk worm is a native of Chim, and it was in that country that the value of silk was first dincosered. It is mom cultivated in parts of the worlel where the climatic onnditions are sulable and where the inhabitants work for sufficiently small wages to make rearing and reeling profitalle. The insect cannot be reared ecommically in the [nited States lecause of the high rate of wages, and it is, therefore, nesesiry to import raw silk for purposes of manufacture.

Raw Silk is obtained ly unwinding or reeling the silk from the cercons, loue since that from one cocoun is ton finc and tow weak to le handled, the threats from several cocoms are reeterl inte a single strand. The cooms are softened by being placed in warm water, and the tangled outer pontion, called "Hoss." is brushed off and forms silk waste. Having foumd the end

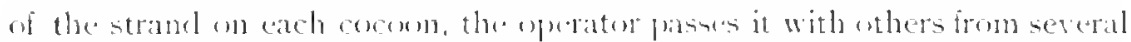

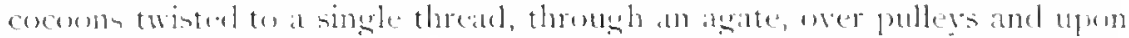

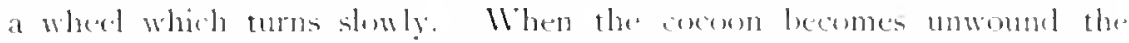

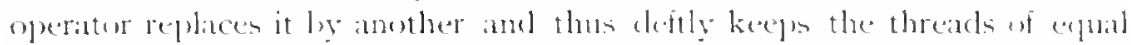
thickness. After a certain amount is rected and r lried it is twisted into hanks. This reeled silk is called raw silk and humberls of coconons are recpured to make a hank of it.

The principal silk prolucing conntries are Chima, Japun, hodia, and the countris bodering the Mediteramean, puticulary ltaly, southern France, Greate, Turkey and western thil.

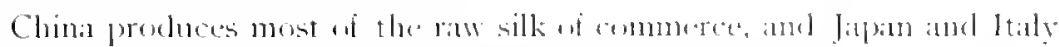

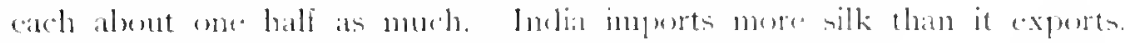

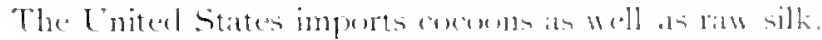

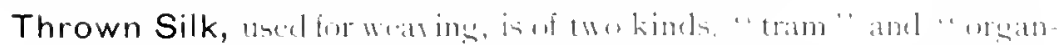

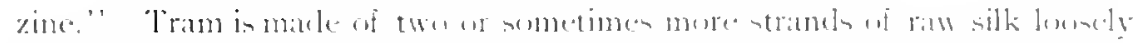

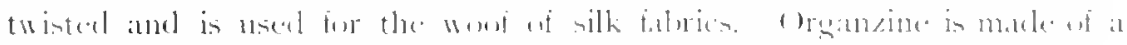

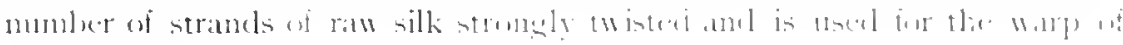
silk Gabrics. 


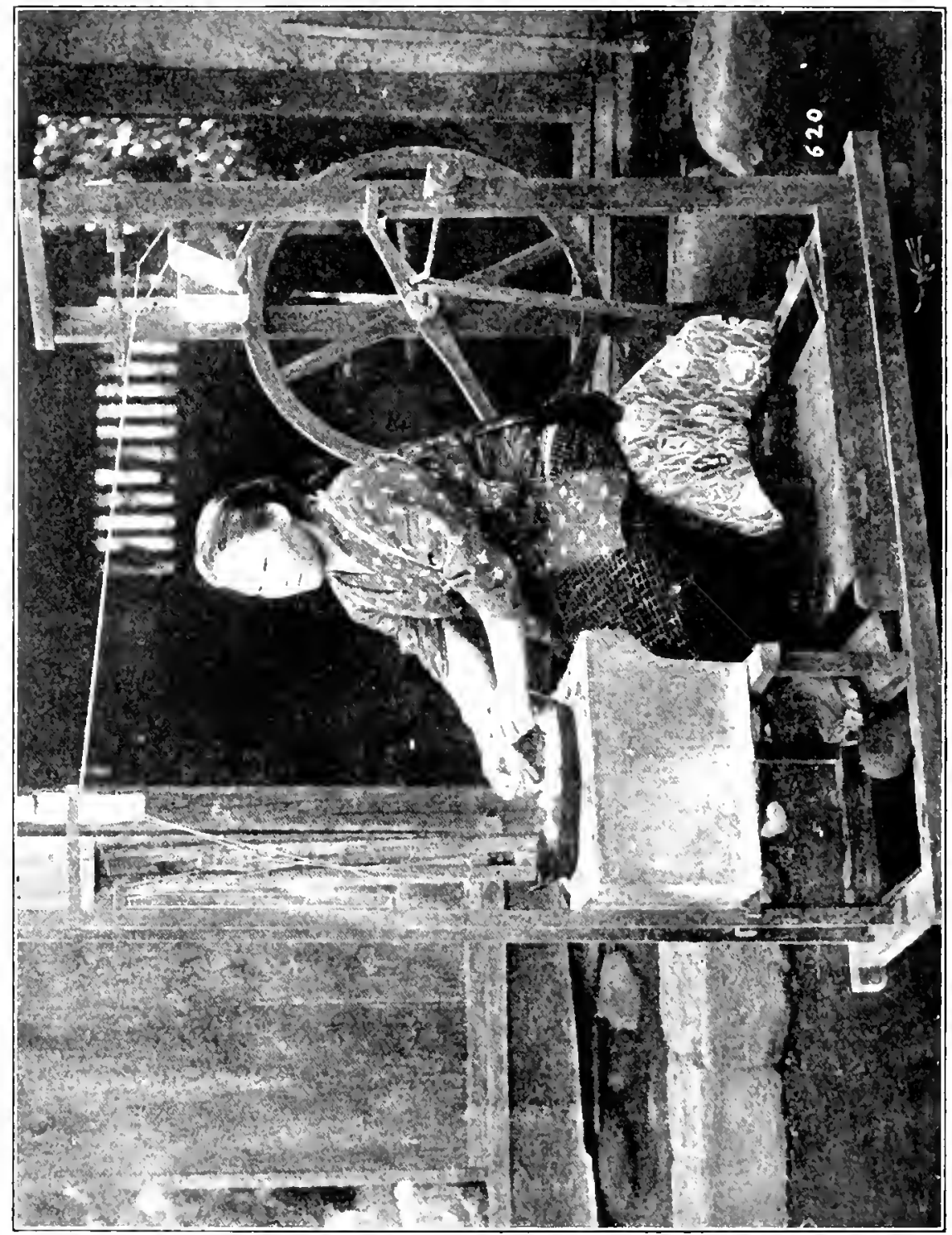


The prineipal fabrico mate of silk ate: silk, satm, plush, chesille, craje, crepon, gauze, dimask, lrociule, pungee and ribbons. Silk threat and cord are also extensively used. The Lnited States is ammon the leaters in the manufacture of silk falorics.

Silk Waste is the "floss" (ur outer tangled mass of silk sulpunting the conoms, which cammet lee reeted) and the "reel tailings" (that which is lete when the reeling of ach comm is completed I. It is imported ly silk manufacturing countrien in comsiclerable amounts.

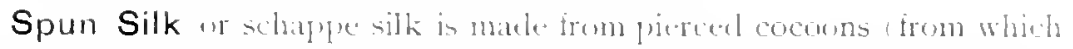
the motho have emersed, and from waste silk. It is manufactured by cleaning and carding the waste anel then spinning it inte thread in somm hat the same manner as cottom is spun inte threml. Falnics made of spun silk are cheaper than those mate if fine silk threal.

Wild Silk. There are other caterpillars that profuce silk. These are the wild worms of Chima and lndia, the silk w which is called " ussah" or "tasar," and that of Japan which is kmon as '. Yamamai." The motho are large, buff coldored insects and the wom ustally feed on wak leatres. The silk is somewhat inferior to that from the oultivated species, and is llacd for pongee, plush and coarser textiles. Other less important species of lndia produce silk that can le cardenl only.

( See Artificial silk,

The lumey bee (.Apis mellifica) lives in colonies. The

THE HONEY wild swams usually stedect a lullow tree for the home. BEE Domesticated swarms are supplied with hives with remoable frames. Eirch hive has one queen, thousands w workers, and may lave many dromes. The queen lays the exsers. The workers, stunted females, collect foud and huilding material, huilel wells, and take care of the hroud and honey. The drones are the male trees. They cannot work because they have not the mecessary organs. Wax is sereted between the abchminal rings of the workers. This they chew and stick om

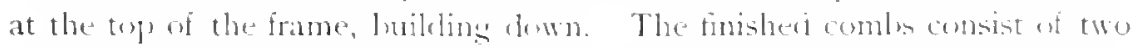
sheets of horizontal, six-anded prismatic cells, with the "penings turned

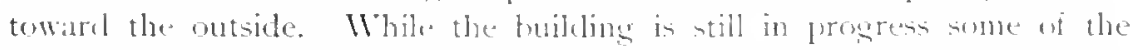
workers besin w collect. They sather neetar which they digest into homey, forcing it ant through their mouths. They fill the cedlowith it, and sed them with wax. Into many of the cells in the center of the hive the fuecen lays

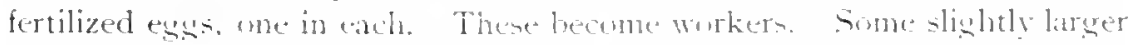

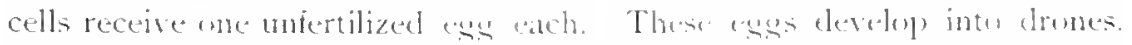

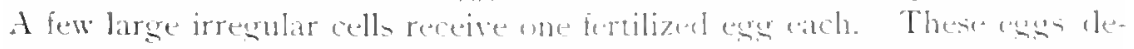

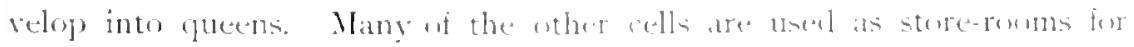
"bee's brearl" , pollen, which is mixed with honey fur foul for the lamate.

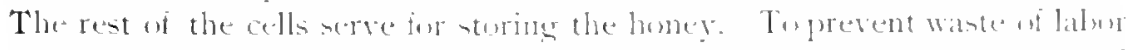

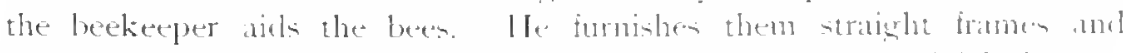

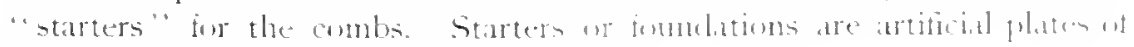
wax, to form the beginning of the oumter. 
Honey. When the crlls in a frame are filled and scaled, the frame is taken out of the hive, the calps if the cells shaved off, and the honey exmacterl by a centrifusal machine. This furnishes extracted honey. The empty comls are returned to the bive to bere-filled by the bees. For comb humey small frames (sections), which hold just about a pound of filled comb are put in the hives. Heney is graded on the market according to the flowers which yield it. White dover, huckwheat, heather, mesquite, horsemint, and mange lowssoms yietd some of the best. A light colored honey in usually prefered. Honcy is produced in enormous quantities in northern Euroje and the Lnited States. To some extent it is produced in all parts of the worlel. It is uscel largely as a frod, in the manufacture of confectionery and sweetmeats, and to some extent in medicine. A variety of drinks is prepalled from it. Extracted honey is often imitated by, or adulterated with, slucuse or syrups. Sometimes beesare fed with cheap syrup, which they seal up just like honey. The resulting comb honey is, of course, only comb syrup.

Beeswax is obtained from the capping of combs for extracted honey, and from condemned combs. It is melted usually by the heat of the sun, and moulded into flat cakes of various sizes. Wax from new comb is light yelliw; that from very old comb is brown. It can be bleached to a pure white by the action of smlight and moisture, or by chemicals, such as chromic acid, nitric acid, etc. Wax is used for candles, waxing floors and threads, artificial plants, figures, salves, and in encaustic painting. Wax is produced in the largest quantities in Europe, northern Africa, and Chile. Almost all other countries produce some wax. There are many substitutes and adulterants for beeswax. The most important of these are stearine, paraffine, Japan wax, carnauba wax, pela wax, bayberry wax, etc.

Lac is a resinous material found on the twigs of many trees of India

LAC (especially butea frondosa and Ficus religiosa). This substance is caused by an insect (Cocrus lacca) belonging to the order of plant lice and very closely allicd to the cochineal insect. The lac insect punctures the twigs for food and then secretes a large quantity of resinous substance ats a sort of coconn and protection for itself and young. This is known as stick-lac, and heing gathered in fluantity from wild trees and those cultisaterl for the purpose it is worked and washed free of useless matter. Red lac dye (before the use of anilines, extensively used) is extracted by the wishing. The dried and ground residue is known as seed-lac.

Scerl-lac is melted and poured nut on broad leares or on metal plates to hatden. The thin sheets which result are called shellac and the thick plates or the drops are called button-lac.

shellac is dissolved in alcohol to make fne warnishes. The ordinary urange colored shellac is bleached with chlorine to make white shellac.

Sealing wax is prepared by mixing shellac with turpentine and various renins.

Shellaw is uned aton in putties, for sizing paper, stiffening felt hats, etc. Dissolied in a strong solution of buax, shellac and dyes are used for drawing inks and some water colors. 
Cochineal consists of the dried boelien of inseets cirens

COCHINEAL acti that betong to the plant lixe fomily and live am cactus plants in Nexion and Central Anericat. Thes hate. been introduced into Algeria, the Canary Istands and the East Inelies. The insects are collected and killed by placing them in hot wens when the. become coated with a waxy. whitish powder. When killed in hot witer or by steam they appar hack and are not so valuable. The principal use of cochineal is as a dye for woolen fabrics. The colur is knom as carmine and is soluble in water: with alumina and tin salts. scarlet lakes are formed which are used for oil and water color pigments.

Cuntharicles are medicinal preparations used ior blister-

CANTHARIDES ing, plisters, etc. They are marle from a beete cienthat is acsicatovia) called Spanish ly, common in southern Europe. The insects are hright metallic green with an azure tint, about an inch or less in length and poseses a naumens smell. Allied insects (species of Mylabris) are used for similar purposes in Inelia and China.

(See Oak Galls.)

\section{BIRDS.}

Poultry and eggs figure largely in commerce. Turkeys. pigeons, and game birds are chiefly of local importance.

Egas, aside from their use as food, are valuable industrially.

EGGS The yolks are used in preparing glove leather and uther tawed leathers and the whites (egs albumen) in making some kinds of photographic paper, in finishing fancy leathers, in clarifying sugar ant for other purposes.

Feathers and hirel skins for ormanental purposes, chicty for

FEATHERS millinery, are ubtained from the ostrich, cock, duck, turkey, pheasant, heron, srebe, and a variety of other hirds. Creat destruction of wild hirds caused strong measures to be taken for their protection and there are now stringent laws in this conntry probibiting the sale of many kinds of feathers and the killing of certain lirels.

Feathers for beds. pillows and uphulstery are pluked from the domestic grose and duck. Down is also obtimed in sulll gluntity from neste of the eider duck in morthwest Eurnpe. Feathers are also used for making Hies for fishiner. Quills are used in making camel's hair brushes and for minor purposes.

Ostriches are the langest of all existing birds ( Stmetho).

OSTRICHES They are natives it the sandy deserts of Africa and Arabial and are domesticated and raised for the ir plumes, on ostrich farms chiefly in South and North Alricas and in smaller mumbers in Areentina and California. Ostrich feathers comstitute half of the imports of fuathers to the lnited States. The hirk are alught and the lest plumes carefully cut from the wings and tails wne in eisht months. For millinery. handsome plumes are made by splitting aff part of the equill and hinding together wo or more in order to get leathers wh applirently heary plumase. 
The plumes are then dyed and curled. Prover feathers are used for making feather dusters. The smaller feathers from the lody of the astrich are also used for millinery. In Argentina and neighboring conntries, a wild bird, the Rhea, of South Americanostrich, has been extensively hunted and its feathers are still exported.

Edible Bird's Nests come from the Malay archipelage and the southeastern shores of Asiz. They are male by certain species of swifts commonly called swallows. These nests are constructed of a gelatinous material and are highly prized by the Chinese for making soups.

Guam is used as a fertilizer. It is composed largely of phos-

GUANO phate of lime and is mostly the excrement which has accumulated as a result of the occupancy of dry islands by enormous flocks of sea hirls. Some quano is also taken from caves inhabited by bats. large deposits of guano occur on islands in the Pacific Ocean and in caves in the Mest Indies and Australia.

\section{MINERAL PRODUCTS.}

Nineral I'roducts may be conveniently classified as follow's:-

Metals and their ares.

Building Stones.

Cements and cement materials.

Glass, Pottery, brick and materials used in their manufacture.

Hydrocarbons, coal, asphalt, petroleum and their products.

Fertilizers.

Pigments and Dyes.

Abrasives.

Lubricants.

Fibers.

Gems and Ornamental Stones.

Medicinal Substances, Tanning Substances.

Acids, Alkalis and other products of chemical industry.

In the following pages these are grouped according to the important metals which they contain.

fron is the most useful metal. It occurs in all parts of the world

IRON and in many substances. The Lnited States, England and Germany are the greatest prohucers of iron. Four minerals are found in sufficient alundance and contain enough iron to he used as ores: hematite, limonite, mannetite, and siderite. Rich deposits in many parts of the worle are at present unworked, because of lack of transportation, distance from conl and limestome, cost of working, or on account of impurities in the ore, such as silica, phosphorus or sulphur.

Hematite is the ore most commonly mined and supplies almost three fourths of the iron of commerce. It is found in immense beds in Nimnesota and Michigan and is produced in liuge amounts in Alabama and other states. Abroad, Germany, England, Spain. France and Russia are the greatest 


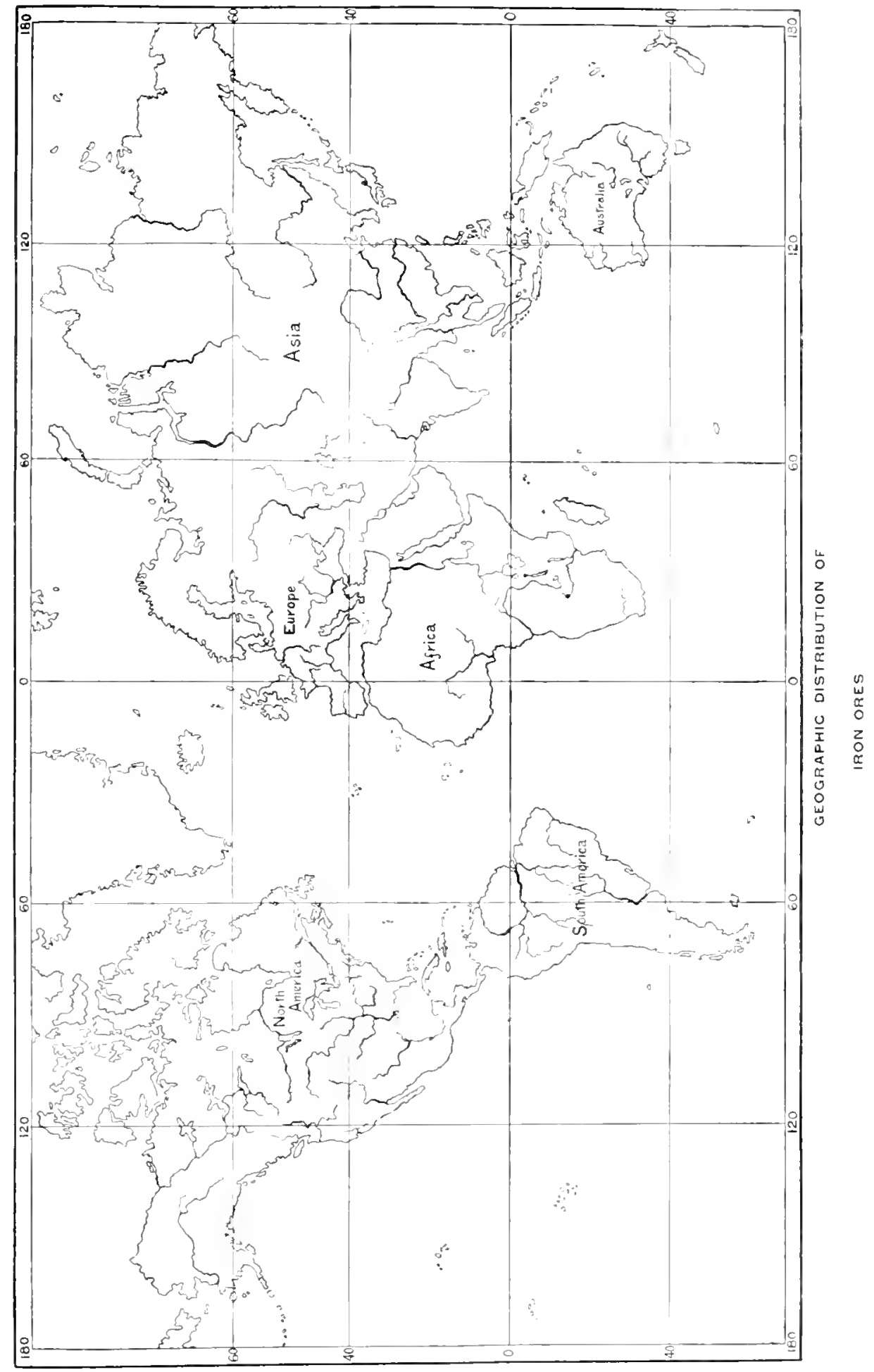



profucers. Ore of fine quality is minel in Elband in sweden. This ore,

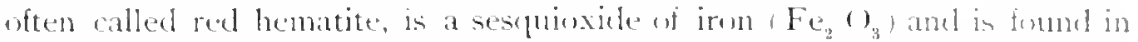
varieties ranging from coystallized to massice, netallic to carthy in aprearance and red to hack in collor. Different kinds are called speculdr iron ente, micacens ore, red wher and clay iron stome.

Limonite or brown hematite is widely distributed. It is a hylomenxide

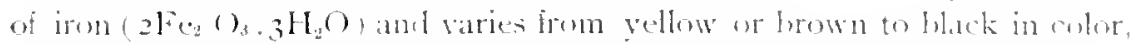
and from submetallic to earthy.

Magnetite or nagnetic iron ore $\left(\mathrm{F}^{+} \mathrm{H}_{3}()_{4}\right)$ and sillerite (carlumate of irom, fec $\mathrm{C}_{\mathrm{s}}$ ) are uned in much smaller amounts than the preceding.

Pig from in made ly smelting iron ore in a blast furnates. The

PIG IRON ore, with arrefully calculated propurtions of limentene and fued, in clumper in at the top, and the homing of the fuel is assisted by the admission of blasts of air around the bettem of the furnate An intense heat is developed and the furnaces are kept running night and day for long periods, wsmally until they noed reparing. The linestone ants as a "flux," cansing the we to melt more casily than it would otherwise. Metallic iron and slis are formed and while melted, run fown to the bottom of the furnace whence they are drawn off, fresh ore, lonestonc and fuel being irequently added. The sliug being lighter thots on the molten iron and is drawn off separately while the iron runs into ditches and depressions in the sand flowr, conling in the form of hars wejghing about a hundreel pounds each, called pigs. The fuel used in smelting iron is usually coke or coal. Pennsylinaia produces about half of the pig iron made in the United States. largely because of the fact that ore from the lake Superiur depesits can be cheaply transported to the neighborbood of the wreat conl fields and coke ovens of western Pennsylynia.

Slag is used for railroad ballat and in making cements and fertilizers. Cast iron is simply pig iron metted and moulded in properly

CAST IRON shaped sand moukt. It is employed for making collumns, stores, large pipes, and parts of machines. It is more brittle and hence weaker than other forms of irm. It often contains these per cent. or more of carbon.

Wrought iron is made from pier iron by melting it in

WROUGHT IRON a puellling furnace where the impuritice, such ats carbom, sulphur and phosphorus, are lemened. Linlike cast iron, it can be altered in shape by hammering It has much weater strength than cast iren, and is used for making hars, flates, wire, structural material and parts of machinery.

Sheet Iron is frequently coated with zinc (sialuanized irom), with tin (tin plate) or with lead (terne plate).

Steel is made by the Bessemer, Siemens-Martin, open hearth and

STEEL wher processes. It contains much less carbon than cast irom and more than wrought iron. It is used where great strength or hardness is needed for rails, leams, structural material, machinery and took of all kinds. Sted wire rope is used for a multitude of purpuses. Many 
grades of stect are produced ly the aldition of small percentages of mansamese, nicket, chromium, tumesten, wr ether metals. By sudden colins. or "tempering" in water or oil, steel can be made of almost any desired hardness.

The chemical compounds of iron are very numerous and hate many uses. Red, hown and yellow ochers are found in the earth, which

OCHERS when ground up with linsecel oil and mixed with turpentine, make paints. These oehers are oxides of irom, like hematite and limonite. Burnt ochers are mate by roasting raw ochers, and give a comsilerable range of cohor. Ochers and inther mineral paints are prejared ly chemical processes, often from the lip-products of other industries.

Red ocher is often called rouge and some grades of this, washed free from yrit, are used in polishing metals.

Sienna and umber are similar to neloers, but contain manganese.

Prussian Blue is an important ilye containing iron.

Copperas and other sulphates of iron are used in dyeing, ink making, and for clisinfecting.

Crucle acctate (pyrolignite) of irom, prepared from a product of wood distillation, is used in dyeing and calico printingr.

lron pyrite or " fool's gold," a heary hass-rellow mineral

IRON PYRITE (iron bisulphicle, $F\left(S_{2}\right.$ ) occurs abundantly in rocks of all ases. It sometimes, but not usually, carries gold, disscminated invisibly through it. Although it contains 46.6 per cent. of iron, prites is useless as an iron ore un account of the sulphur from which it cannot be successfully separated, hence its chief value is as a source of sulphur for chemical work.

Its most important commercial use is in the manufacture of oil of vitriol w sulphuric acid $\left(\mathrm{H}_{2} \mathrm{SO}\right.$, , for which purpose it is roasted or burnt and th: resulting sulphur dioxide gas $\left(\mathrm{SO}_{2}\right)$ is further treated. Sulphuric acid is a rhemical of great importance in many inclustries.

Prites is also used in the manufacture of sulphite pulp for paper making, and in the preparation of some pigments.

Manganese ores are mined in Russia, Brazil, India and in MANGANESE smaller amount in other countries. They are used chiefy in the production of forro-manganese and spiegel-eisen, preparations used in steel making. They are employed also in making howhing powelers such as chloricle of lime, in ghass making, in the manufuture of oxyent and for various other purposes.

Pyotusite foxite of manganese, In $O_{2}$ ) and psilomelane are the chicf ores.

Jecarl is the softent, heaviest and mont malleable of the common

LEAD metils, as well ats one of the most easily melted. The Enited States, Spanin, Germany and Mexico prenduce the most lead, but it is found th some extent in nearly all parts of the workl. In this country, the most important hed mines are in hahe. Colorate, Ltah, Nissouri and Kansas. Wo import numel lead bullion from Nexico. 


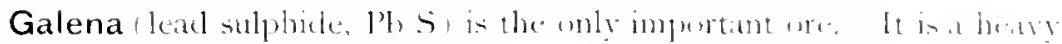
lead-gray mineral with metallic lustre. It often arstallizes in culnes, int the cre is enenerally gramulir-masive.

Componates, sulphates and ather leat componmts are less common in nature:

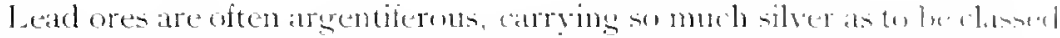
as silver ores. After smelting, the silver is extracted from the lead bullinn.

lead is used for making lead pije, sheet leat and leat shot.

Type metal is compusent of leat and antimusy.

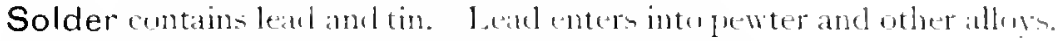

Sleet iron conted with leatel in ralled terme plate.

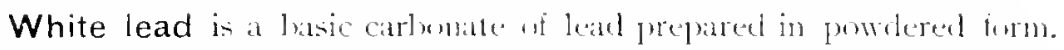
Ground up with finsed oil and mixed with boiled wit and turpentime it makes the best white paint kmown. White leat is also employed in shoring earthenware. It is frepuently mixed or abluterated with cheaper sulmances such as lead sulphate, barte or chalk.

Red lead (leat? wide is used as a proment and in making flint alans.

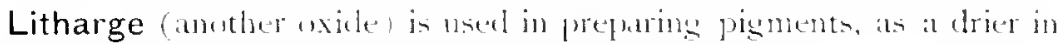
making lusted linseed oil, and hor wher purpuses.

Orange mineral is anuther leatl pisment.

Chrome yellow lead chromate is uned an a prignent and an a dye.

Lead acetate is weed in dyeing. Lead soap is used in pharmacy.

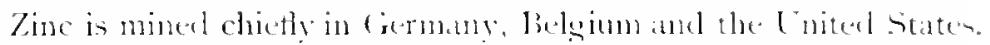

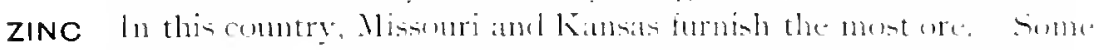
is mined with silver ore in Coldrater and some comes from northern New Jersey.

Sphalerite, or blende zinc sulphicke, Zn Si, called "Jak" " hy miners,

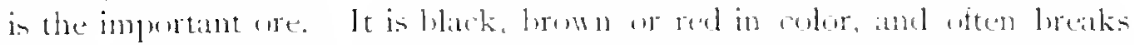

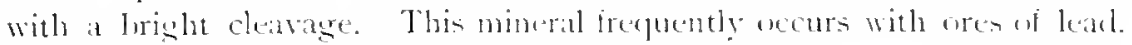

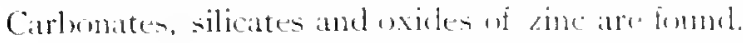

The orde metal called spelter is whained by distilling the romed ore or from the mixture of vertust metals in the "matte" from smelters.

Zinc is used in electrie batterits. in making hydrogens in the cymide. process for the recovery of andel. and in makiug atched platen for printing. Sheet zine fincs various industrial applications.

Galvanized iron is make ly dippins sheet irom in melted rine, the. thin zinc conting preventing rusting of the irous.

Brass is all alloy of coplere with sinc.

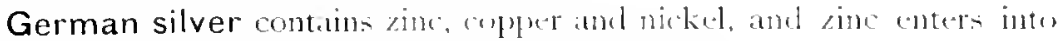
various other alloy's, including some kinds of solker.

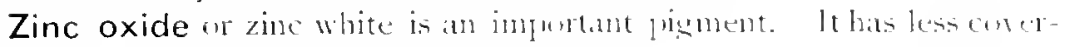
ing power and is less valuable than whitr leakl.

Zinc sulphate is used as a pigmente in lyeing and at at dininlectunt. Zine chloride is used as a woul frenervative. 
Ciglper, from an exemomic stomelpoint, is one of the most im-

COPPER portant metals. The L'nited States is the ereatest profucer. Nearly all of the ontput is from mines in Montana, the lake Superion district and Arizona. Cinper is probluced in smaller quantities in Spain, Japan, Chile, cremany, and many athere parts of the world.

The ores ary widely in compunition and becurente. Native copper in metallic particle mixed witl ruck in the principal ore at the Like Superior mincs. Chalcusyrite and lomite (sulphicles of copper and iron) are found in many parts of the wolle. Chalencite (copper sulphicle) is an important ore in Montana. Malachite and azurite (carbonates of epper) are common ores in Arizona. Copper oxides and opper silicate are also found. These ores are of many colors and often oceur associated with or carrying other metals atch as ankl, silver, lead and zine.

The ores, after concentration, are usublly roasted and smelted, and the resultant "copper matte" is separated by refiners into the various metals whel it contains. Electrolytic processes of refining are largely employed.

The demanel for equper has increased enomonsly in recent years, due to its use in electrical work, where it is mosty empleyed in the form of coppert wire.

Copper is used also for making coins, pipes, kettles, cartridge shells, plates for engraving, for plating ships, roofing and plumbing. Componnds of coplere also furnish blue and green dyes and pigments.

Brass is an alloy of copper and zinc.

Bronze contains copper and tin, sometimes with the addition of zinc. Phophor bronze, aluminium bronze, statuary loronze, fell metal, gun metal and Britannia metal, are other alloys containing onper.

Blue vitriol or coper sulphate is the most imprortant of the numerous chemical compunds which contain copper. It is used in the preparation of electrolytic baths, in dyes and piements, in silver refining and as an antiseptic.

Gold is found in nearly all parts of the world. The Cnited States.

GOLD South Africa amel Eustralia contain the richest gold fields known. In this country, Colorado, California, Alaska and South Dakota are the largest producers.

Guld is usually in minute particles disseminated througl rocks or sands. When in ruck, it is trelinarily found in reins of quartz, sften associated with pyrite or wher sulphicles.

Tellurides of pold are mined in Colorade and Transylyania.

Gold washing. I'lacer deposits consist of herls of sanel or gravel derived from the weang away of rocks, and contain gold in grains and mussects. Some placers are extremely rich and from them the metal is obtained ly washing. The crubest methed is ly rocking a small quantity of the gravel in a bain of water, the particles of gold, heing heavy, sink to the lxitom and are asty collected. On a larger seale, gold-hearing gravels are washed by a cument if water through shices or long werclen gutters. The gold is caught by strips of wood callecl "riftles," fastened thagonally in the bottem of the shice. 


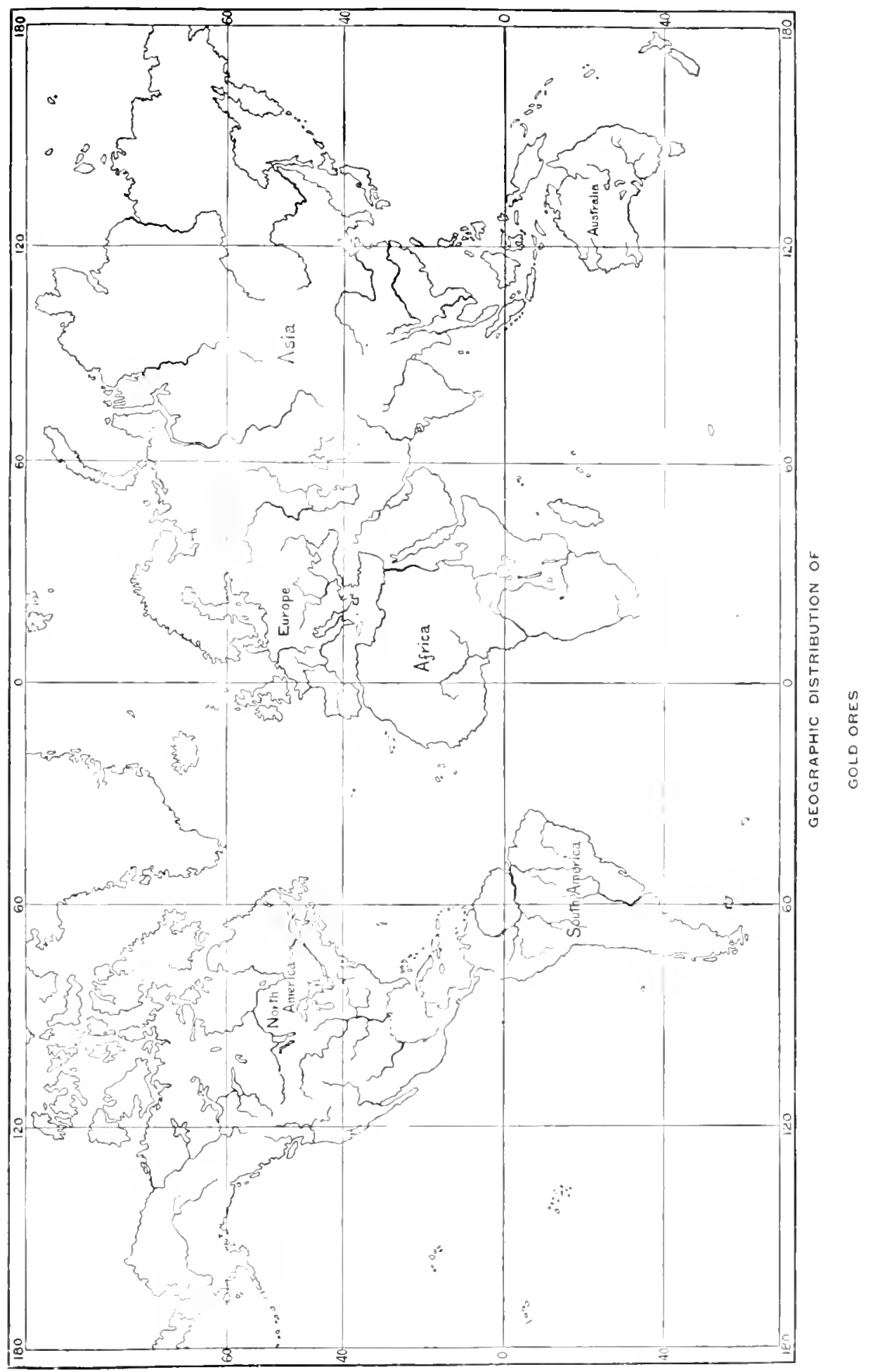




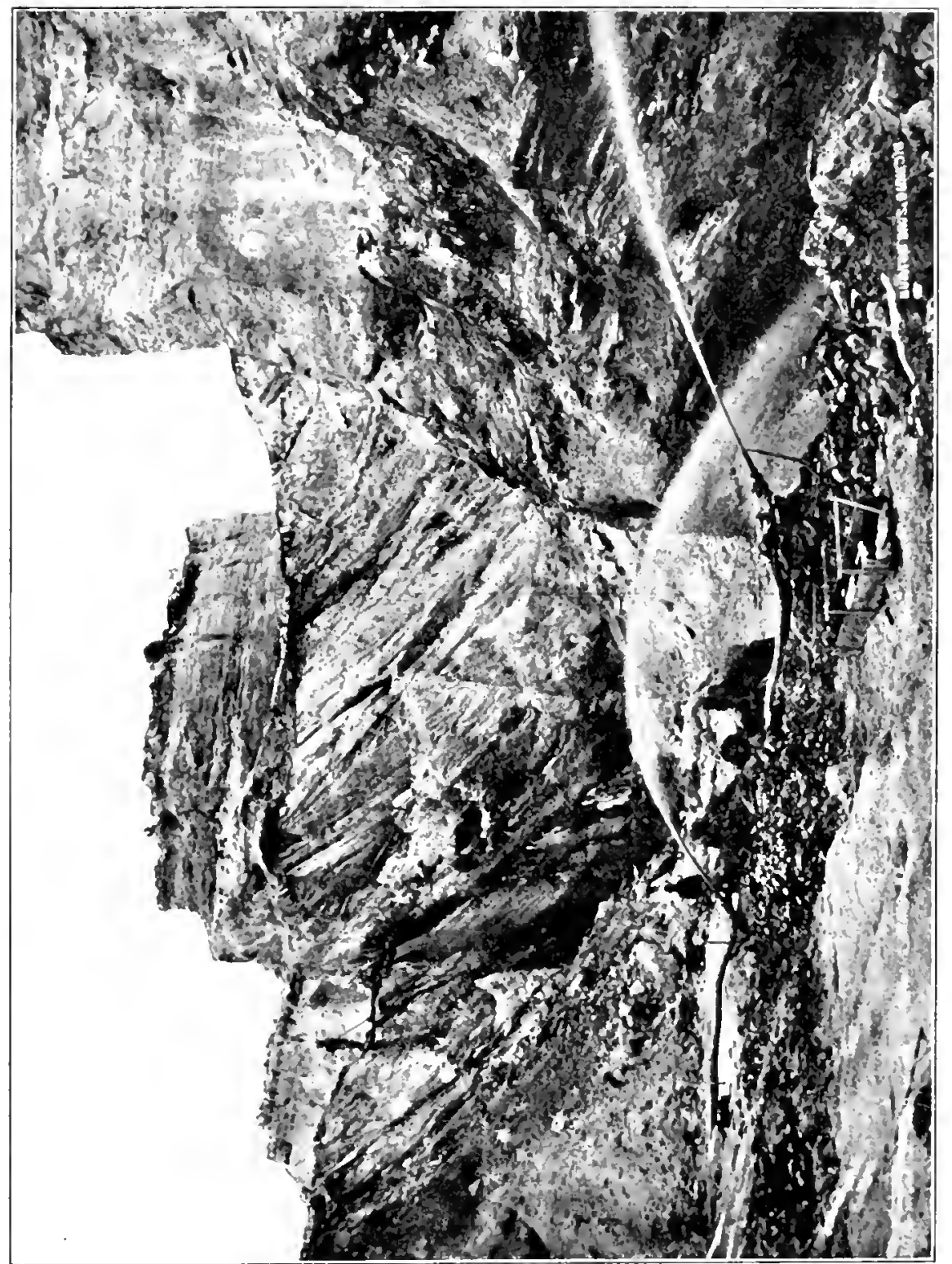




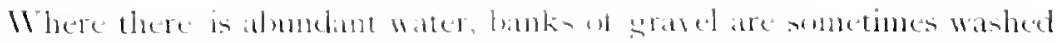

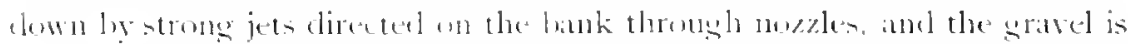

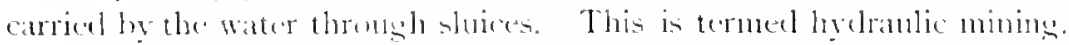

Gold recovery. Racks which contin golel, after breaking, arecrushed to a fine pulp with water, in stamp mills. The pulp is pasicel over copper plates covered with mercury which catches and forms an amalgam with the particles of gold. It is usual to separate, by concentrating machines, the heary from the lighter part of the pulp after it passes the plates, and to treat the heary concentrates by smelting, chlorination, or the cyande process to recover gold which was not caught by amalgamation. Cold is soluble in a solution of cyande of potassium and may le recowed fom the solution by treitment with zinc. This process is successful with ores which contain comparatively litte gold and has mate possible the profitable working of such depusts as these in South Africa.

Golk is used chefly for jewetry and currency. It is ralued on account of its risity, its beanty and hecause of the fact that it does mot reaclily tarnish and is not attacked by ordinary acids. It is almost always alloyed with copper or with copper and silver. Lnited States sold com contains 9 parts of gold to $\mathrm{I}$ of copper. Pure gold is said to le 24 carats fince and the best ordinarily used is about of carats fine. Coll is used also for making gold leaf for gilding, and in dentistry. Chloride of gohl is used in phentography.

Platinmm is a rare metal found with gelel in grains, in placer

PLATINUM washings. Russia produces ninety per cent of the wonld's supply and the remainder comes from Colombia. Small amenuts are fomel in Califonia, Wyomine. Canada and Australia.

It is used in the form of rery finc wires in incandescent electric lamps to comnect the teminals with the carbon filanent. It is also employed in snaller anome by chemists and clentists.

Asseciated with this metal is another rare one, iridium, which is emploperl for the points of gold pens.

Silver is mined thrombout the Rocky Monntain and the Andes

SILVER regions of America, in Australia, and to a small cotent in many other parts of the world. In this country, Colorade, Mon-

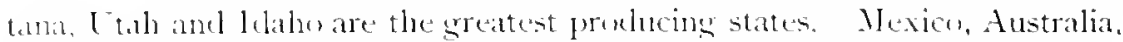
bulivi. Chile, l'en, and Germany take rank after the Liated States ats produsero of this metal.

Argentiferous galena is the most commm nome ant the source of at very large fercentage of the sitrer produced in the world. The amount of silue carried by this sulphide of lead varies greatly, lut a very few munces of silver in at tom of ore make it profitable to wok many deposits of hacl "hich coukl not uherwise be mined.

()res of zim and copper, ecurring separately or associated with ores of leal and wher motale, frepuently carry silver. Almost all wald is found

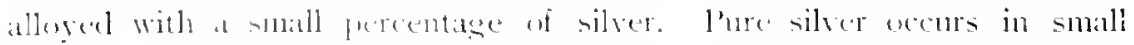

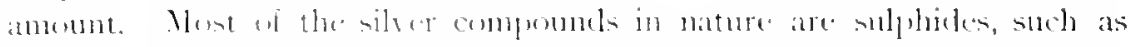

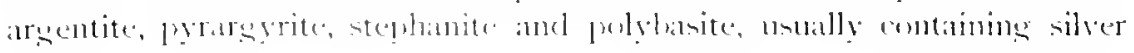




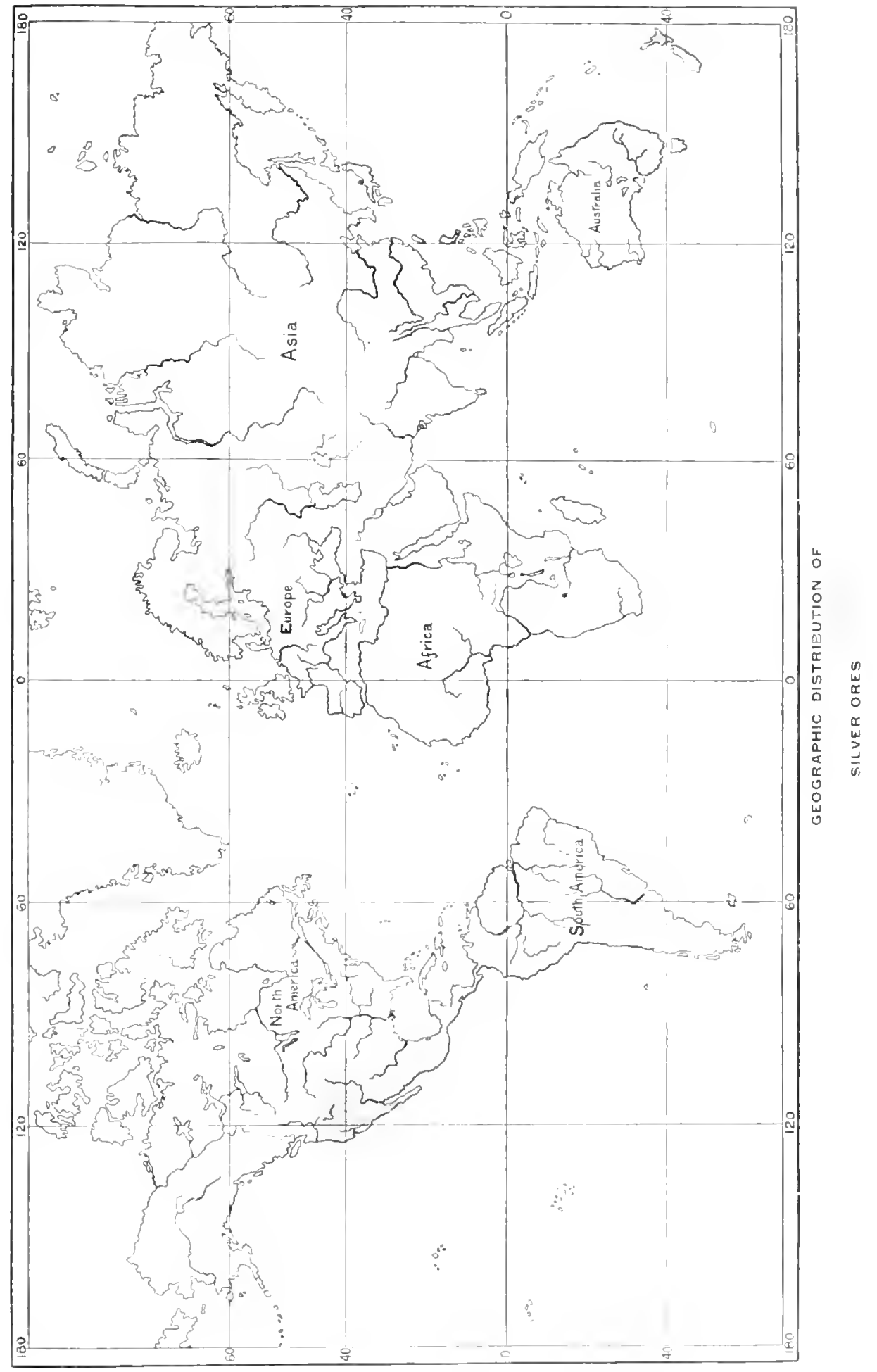





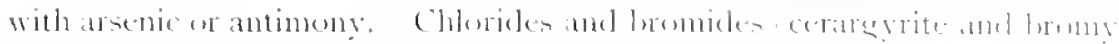

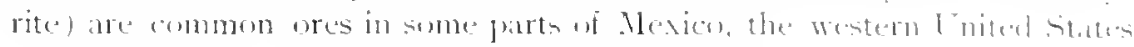
and Australias.

Silver is extracted from ores by smelting, and robing the resultant

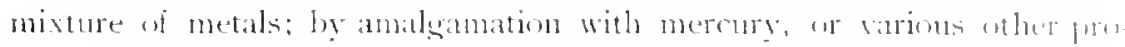
cesses. It is made into useful and momental articles for the houselublamel persomal alomment, many of which are formed of some other motal w alley

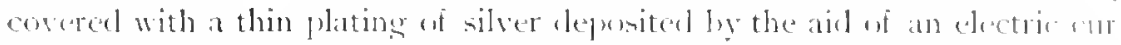
rent from a solution of cyankle of silver anel fotassium. The tarnish often seen on silver is due to its union with sulphur alsorledel from gatses formul by burninger coil.

Solid silver articles, including coins, are almost never made of the pure metal, but are alloyed with onper to harelen them. The price of silver has derlined greatly within the past thirty yours, so that at present there is lest than fifty cents worth of silver in a silver dullar.

Nirrors are male hy coating one sicle of endss with silser from a solution. Nercury was formerly used for this purposes. Silver chloricle and silver nitrate are nsed in fhotegraphy.

The mixture of various cheaper metals forms alloys such as pewter and white metal, which resemble silder in colot and luster.

Mercury on quicksilver in found in Sirain, the L'nited states.

MERCURY Austria, Italy and Rusia. Nurly all of the mereury (d)tained in the Inited States comes from Collornial and a much smaller amount from Texis. One half of our proslution is exported to Mexico, China and Central Anurioa.

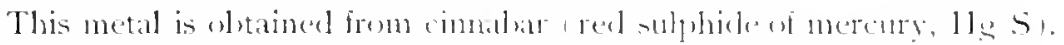
It occasionally occurs in a pure metallic state and in a few rare onmpunds. It is extracted ly heating (clistilling) the ore. The moreury, which volatilizes readily, is condensed as the gases are conled after possme from the furnace.

Nercury is peculiar in being a heary metal which is licpuid at ondinary

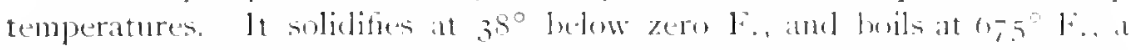
lower temperature than the boiling point of any other onmmon metal. It is

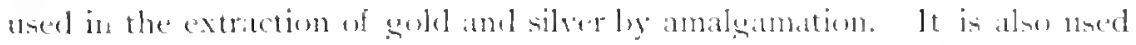
in silvering mirors, for thermometers and hatrometers.

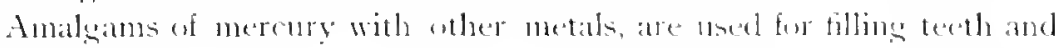
other purjoses.

Vermillion is artificially prepanter cinmaloar, and this, as wedl as other compounds of mercury, are used als prismonts.

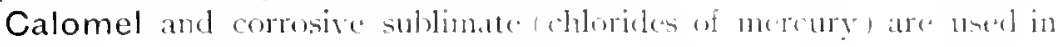
medicine.

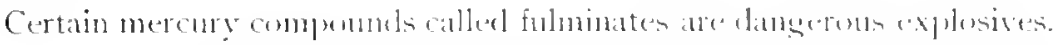

Aluminium of aluminum is at metal which has leeen suc-

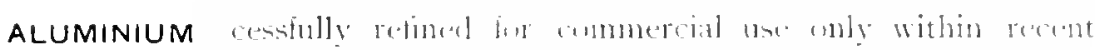

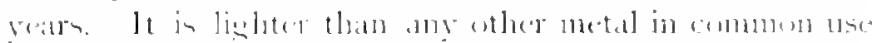

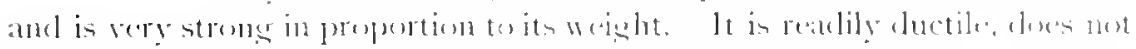

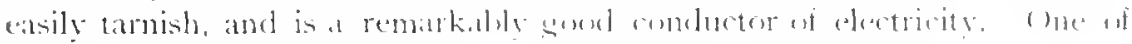


its most important uses in an an adelition tw iron and steel, preventing bubhles and wate in eastings. It is extensively employed as an electric conductur. It is used for the construction of some kinds of machinery, for hulls and plating for bats, cooking utensils, comber and ether artickes. As a substitute for stome it is used in the manufacture of litherratphic plates. Alloys of aluminimm with apper and other metals, forming aluminium bronzes, are used for a great rariety of purposes.

Aluminimm ocours very aloundantly in the crust of the earth and forms mumerous uscful componmels.

Bauxite aluminium hychate, $A \mathrm{l}_{2}()_{3}, 2 \mathrm{H}_{2}, \mathrm{)}$, is the ore from which aluminiun is extrateded, anel the only mineral from which it is now obtained commercially. It is a clay of peculiar composition, being a hychate, while most elassare silicaten. This ore is mineel in only a few places in the world. In the Enited States it eccurs in Arkansis, Alabama and Georeria, and in Europe in france and lrehanel.

In the refining of aluminim, calcined batuite is lecomposed by a strong electric current. In this cenntry, the power which supplies the electric current is gencrated by Niagara balls. where the metal is refined.

Cryolite (fluoride of almomium and sodium, $3 \mathrm{NaF}_{\mathrm{i}} . \mathrm{AlF}_{3}$ ) is a white mineral which is mineel only in cireenlanel. It was formerly used as an ore of ahminium. At present it is of value in chemical manufacture as a source of flumides and other salts, such ats carbonate of sold, sirla ish, alum, alumina, ete.

Aluminium compounds. Corundum, felelspar, and day contain large

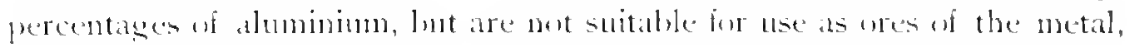
becalse ther contain silica.

Corumdum aluminium axicle. $\left.\mathrm{Al}_{2} \mathrm{O}_{3}\right)$ is, next to diamond,

CORUNDUM the bardest natural mineral. In Ceylon, and accisionally in Montama, North Carolinat and other places, it accurs well crystallized and transparent, sometiones colorless or blue sappluie) and sometimes recle ruby). These are valuable for gems. When accurring pure or nearly so, but not tramsparent, ats it does in Canad., Nortle Carolina, Alabamat and Montana, it is ground up for use as an alorasibe.

Emery. A less pure variety called emery contains considerable iron and is mut quite so hard. It is extemsinely uned as an abrasive. Emery is found at Chester, Mass., l'eekskill, New York, and in Greece and Asia

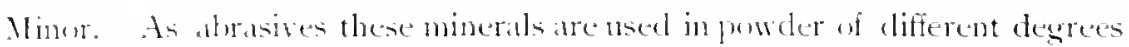

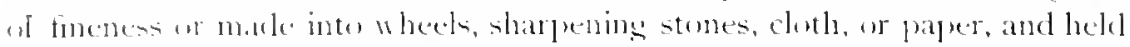
together ly some erementiog material. Commlum (alumdum) for abrabive purporas is aloo mate artiticially.

Felespar is fomnd as a constituent of all granites and similat

FELDSPAR rucks. When it recurs in moderately pure milsoses, at it does in Dedaware Comnty. Pennsylyand, in Connectiont, New York and Sorwaly, it in mined and used in making pottery. Jeklspars are silicaten at atuminimm with uther metals stell an potassum, solium, or cal-

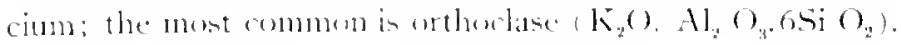


Clay is msually a product if the nutural decas or alteration of

Clay felspar. It raries greatly in composition like the rackis irnm which it is clerived. It is composed chietly of hydrous silicante of ahminimm, mannesium, and other metak. The purest day, kalin, is

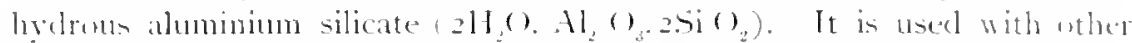
subances in making the finest puttery. Less pure clays are useal in muking tile, arthenware, stoneware, tera cutta, brick and trebrick.

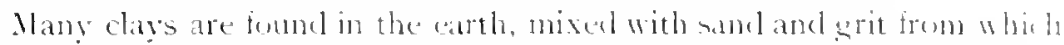

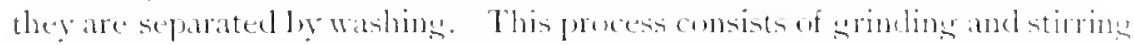
the claty up in water whish carries off the the particles in suspension while the corarse part remains behind. The wated contaning the fine particles is annducted to settling tanks and allumed to stand till the pure clay is elepesited.

Clays are fitter for making pottery in popertion to the casts with which they can be momkled ame shatged when wet and their change to a hard unalterable condition when they are fired. Many kinds of che are uned in making pottery and on their nature and propurtions and the beat w which they are subjected in firing depends the guality uf the resulting procluct.

Porcelain, w china, in mate from a mixture of katolin. quartz and belat-

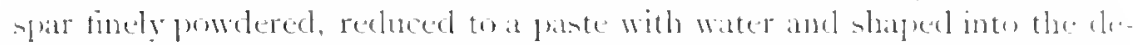

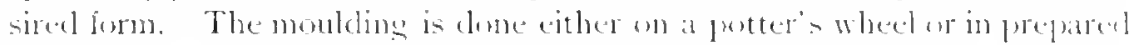
monlels. The fragile "biscuit "wate is then Lume on "fired" in a kiln, after which it is decorated, a glaze applied, composed of similar materials in proper proportions to fuse to a glass, atter which the articles are re-fired. The decoration is sometimes applied ontsiele insteal of moler the glaze. I

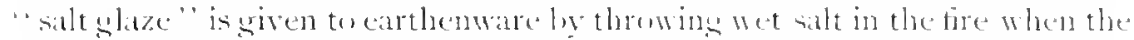

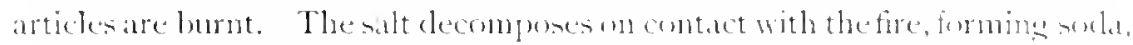

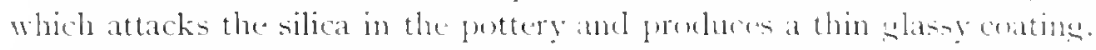

In the Lnited States, Ohw, New Jerney, Mnnsylyana and Went Virginia are the most important puttery-making states: Fine wares are mate ahroad in England, France, Grominy, Austria, Japan and China.

Bricks are mate of the commun kimb of clay containing emotgh samel to prevent undue shrinking. The elay is groned to a smowth phote with water, monleded inter a rectangular roxl and cut inte lengthe. Bricks are burnt in heaps or in kihns and if the clay contano fron, ther ansunne a reet

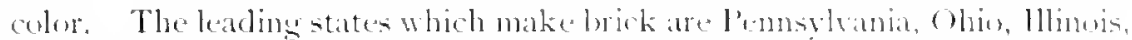
New York, New Jersey, and Missenti. The kinds which will sustain the sreatest heat are called fire-brick.

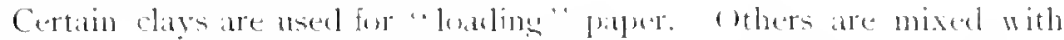
limestone in makinge Portland ecment.

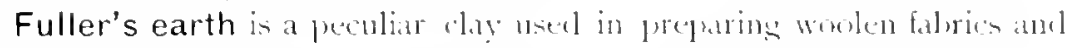
also) for filtering (rils.

Slates and shales are clesely related to days. They eften on

SLATES tain lime, and approuch charey limetome in composition.

Slate is a bery important reming material. It is used alon

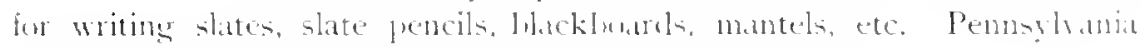
and Vermont produce nearly all notamel in this comatry. 


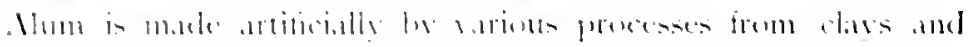

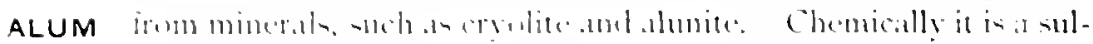

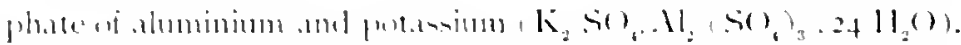

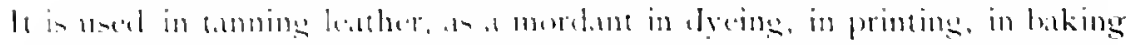
purkers, in melicine, in sime piper. in stucen work for hardening plaster,

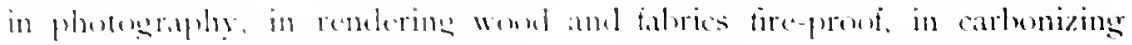
wark. in bletshing. e.ts.

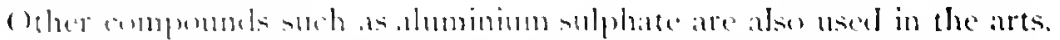

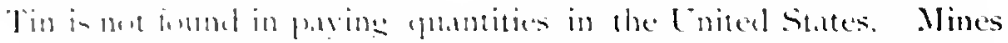

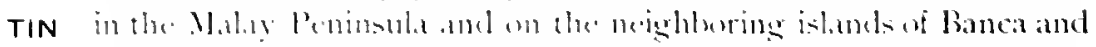

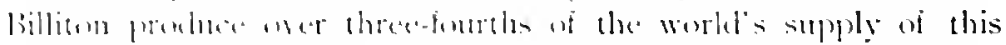

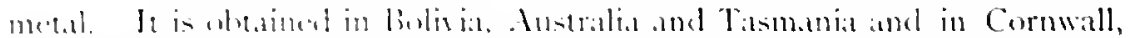
longlome in ane ient times the only smore of tin). It ocemsalso in China,

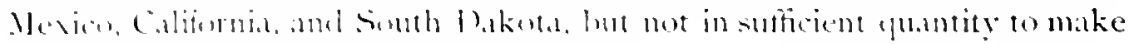
it mining. at present, portitalle.

Tha anly important are of tin is assiterite tin axide, Sn $O_{2}$ ). It some-

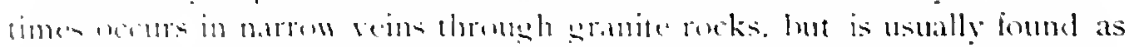

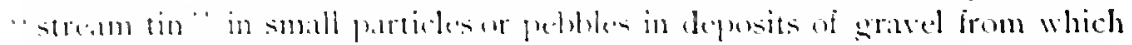

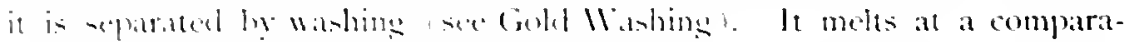

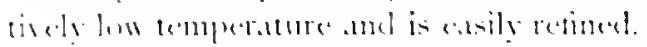

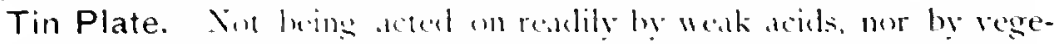

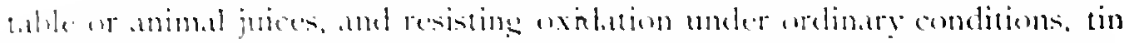

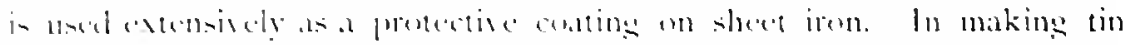

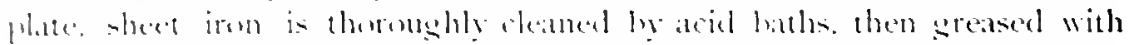

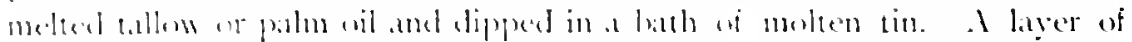

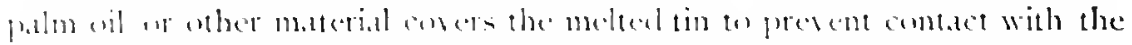

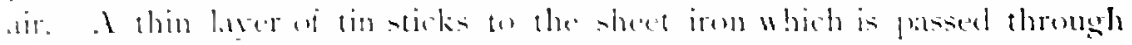

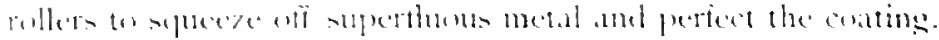

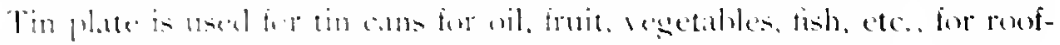

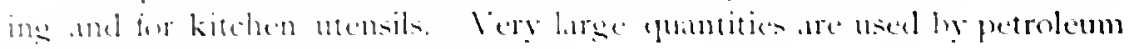
methers and he conneries in sermeral.

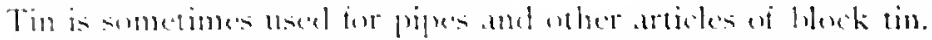

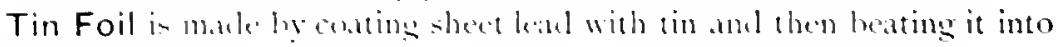
thin sincets.

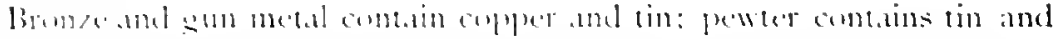

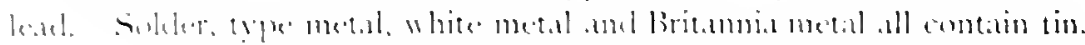

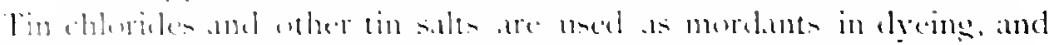

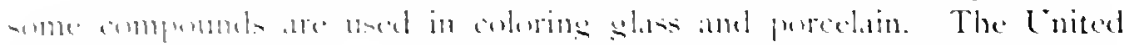

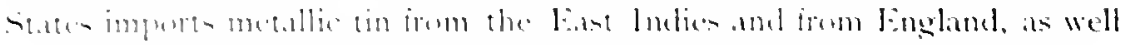

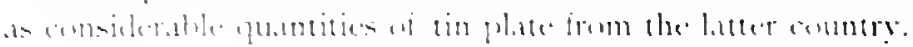

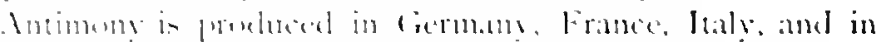

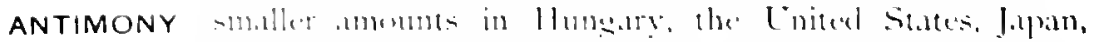

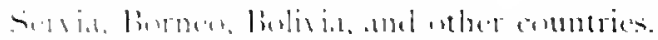

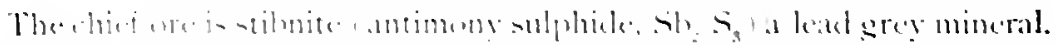

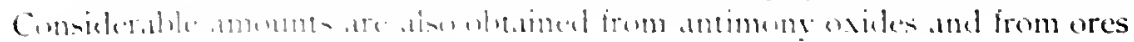
of lowd which ant antmons 


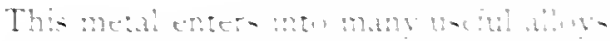

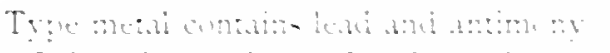

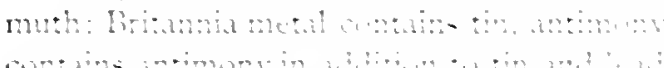

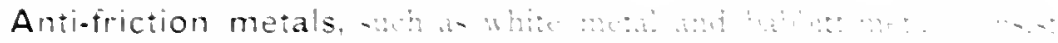

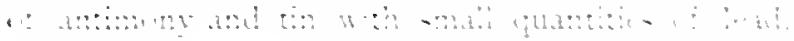

and nise

Tartar Emetic

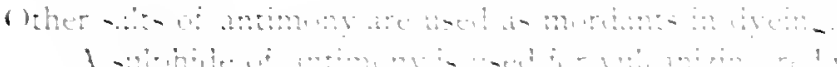

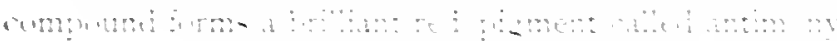

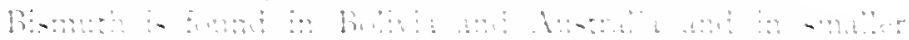

BISMUTH

¿

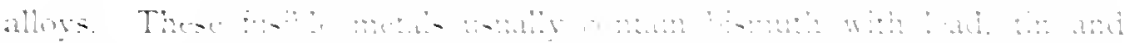

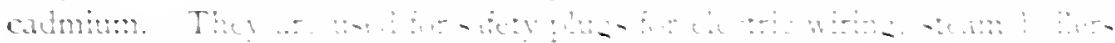

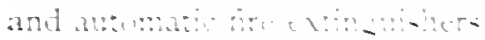

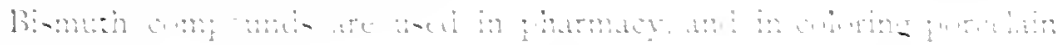
a.ad atis.

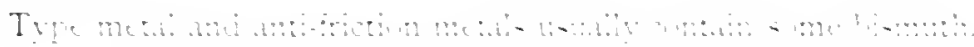

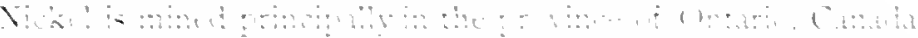

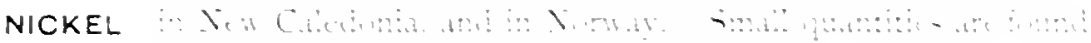

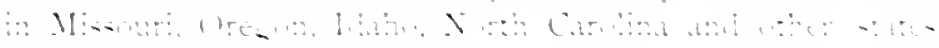

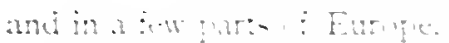

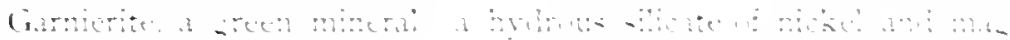

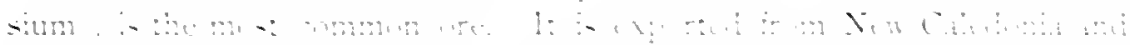

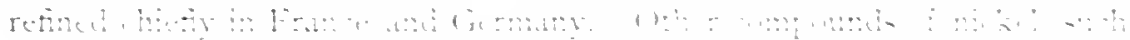

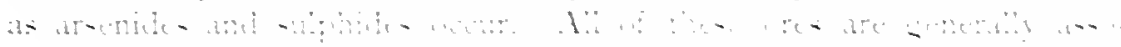

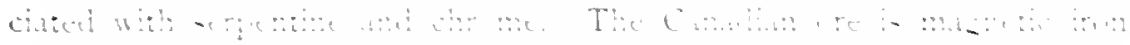

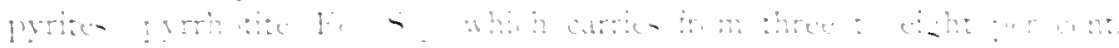

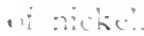

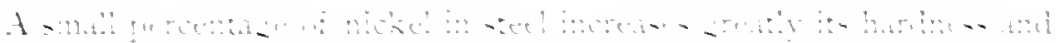

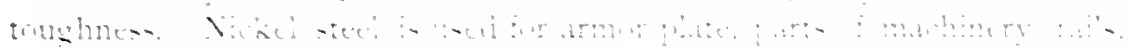
and wire rente

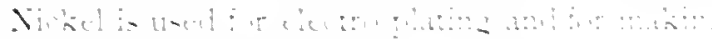

German Silver

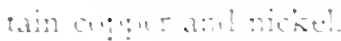

COBALT MIMA-i Det

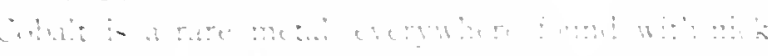

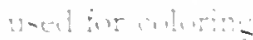

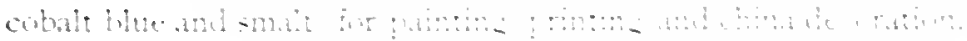

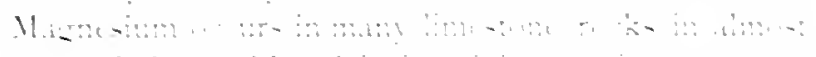

MAGNESIUM

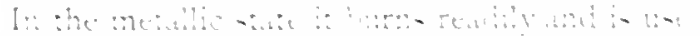

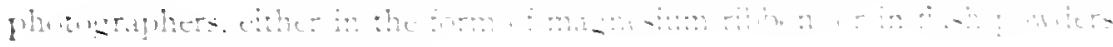

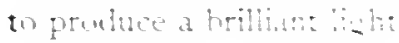


It principal notural compenumb are chloricles and sulphates, fomml at Stasfurt, (jomany: magnesum carbonate (manesite), whaned in (irece. Austria anel Calibunia: musnesium calcimm carbonate (dolomite); hydrous magnesium silicates, tale or soupstone, serpentine, aslestos and mecrscham. The metal is reduced from the chlorides.

Magnesite is used in making carbon dioxide gas for tharging soda Whater, minetal waters and beer, and for refrigerating. After heating magnesite, the residue, called ralcined magnesite or masnesia, is made into bricks of concrete and used as refractory lining for steel furnaces. Masnesia is also worked intu fireprow and non-conducting cuatings on steam pipes, and to a small extent in toilet poweders.

When the carlmo dioxide is disengaged from magnesite 19 sulphuric acid. Epsom Salt ( $\left.\mathrm{Mg} \mathrm{SO} \mathrm{O}_{4} .7 \mathrm{H}_{2} \mathrm{O}\right)$ is formed.

Manceste and dolomite are both used in preparing sulphite licpors for use in wakl pulp paper making.

Dolomite is extensively used as a building stone under the name of mannesian linestenc, or simply limestone, and is harder and more durable than purer linuestune. Calcined dolomite is uncel as a lining for iron furnaces.

Talc is a rery soft mineral, easily seratched ly the finger nail. It is

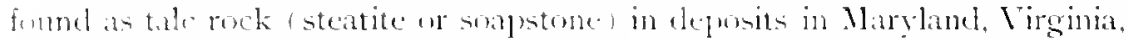
North Carmlina, New Jerser. P'ennsylumia and other states, and is imported from France and lably. It is used in making bath and landry tubs, firefrick, hearthstones, mantels, sinks, gribllles, slate pencils, tailor's pencils, a.l tips and other artickes. When powedered it in employed for foundry facings, lubricating machinery, dressing skins and leather, in paints and toblet powers. A peculiar fibrous variety from Xow lork is used as "filling" or "lourling" in paper.

Meerschaum Seprolite is a day-like mineral fomm in Asia Minor. It recurs in lomps of irresular shape and is used for carring into pipes and ind holders.

Serpentine is a prewish rock found in many parts of the world. It is wfon used as builing stene. Verd-antique is a natural mixture of serpentine with matble, which, when pelished, is used for ornamental work.

Asbestus, w abbestes, as it is usually found on the market, in a fibrous rariety if serpentine (called chrssotile). It is mined in the province of Endrec, Cantalu, and is valuable on account of its incombustibility and as a nem-combluter of heat. It is yrun and woren, usually with a small quantity uf rescetalde fiter to give greater strength, and made into theatre curtains.

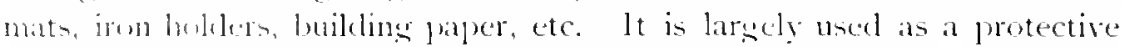
corering on steam pipes and boilers. It is also used in paints. A fibrous barjety of amphibule is also known as asbestos, the best being the longfiber ltalian.

Mineral Wool, sometimescalled rock woml, silicate cotton or asbestos, is an antificial sulutince produced by melting slap and limestone, and converting the molten mixture to a rery fine fibrous state by means of a steam 
blest. It is useal for much the same purposes ats true abbestes, but canmen be spun into thread. It is extensively empleyed ats a fire-prof packing material in walls and floors and as a non-conducting packing aremel boilers and steam pipes and in refrigerators.

Other metals are seldom refined, not being at prosent

OTHER METALS of much commercial use in the pure state. Cialcium, soxlium, and potasium form many useful compounds, both in their natural state and when prepared ly chemical processest.

Titanium is nut an uncommon and usually a rery unelesiralle onnstituent of iron ores. Menaccanite is a mincral containing titulum, which although it contains a litere percentage of iron is almost useless as an wre.

Rutile (oxide of titanium, Tir), is ustel in coloring fulse tecth.

Sereral raremetals are used in small amounts for making certain graves of steel. The most important of these are tungsten, molyblenum, vanadium and uranium. Salts of these metals find limiterl use in fyeing.

Radium, a rexy rare metal with rery peculial properties, accurs with uranimm, and is at present used in expermental work.

Lithium carlonate is used in the preparation of medicinal tallets and mineral waters. It is prepared from cortain rave nincrals which in this comentry are found in quantity in California.

Monazite, samarskite and a few rother minerals found in Noth Carolines, Norway and brazil ontain thorium, cerium, lanthanum and ytuinm. Salts prepared from them are nsed in making the mintles for Welsluch and other incandescent was lurners.

Arsenic orenrs wielely diatributed in the worlel, lnt in anly at

ARSENIC few plices in sufficient quantity to be of commercial value.

Germany, England, Camala, the [nited States anel Spain are the producing countries.

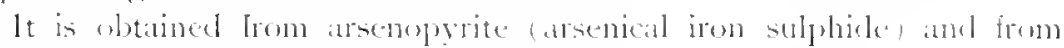

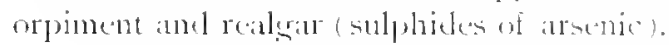

It is uned in the form of uxibe of arsonic called arsenic, white atsenic or arsenious acid) for preserving skins, for makins "sheep alip" (to kill insects which harm the sheep', fur rat poison, as a murdant in dyeing, in making fune grates of glasswate and enamels, and in making rarime other arsenic compounds.

Paris Green, one of the most imputint arsenic salth, is used for killing the potate betle and other insects injurions to regetation, anel, to a small extent, as a pigment.

Other compounds of aremic are used ts prigments and dyes, for medicinal pupposes and in making embalming fluid. Arsenic silts are used in preparing certain of the conl-tar colors.

Chrome ores are mined in tsia Minor and Greede Smaller

CHROME amounts come from the province of Quelece, Canadi, New Calcetonia, and California. There ante eleposits also in the Ural Nountains, in Lancaster County, Pennsylvania, in Maryland and North Carolina. 
Chromite axiche of chromium and irom, Fe $\mathrm{Cr}_{2} \mathrm{O}_{4}$ ) is the only ore.

Chromium is not used in the metallic state, but is chicfly valuable for its chemicil compounds, particularly the pigments chrome rellow and chrome areen. Various salts of chrome are used as dyes and mordants, giving a variety of colors. Chromic acid and bichromate of potash are used in tanning soft kid leather. In the tamning industry, bichromate of potash is often reforred to simply as chrome.

Chrome steel contains a small perentage of chromium. It is extremely hard, being used for hurglar-proof safes, hard-edged tools, etc.

Barite, or harytes, is a heavy white mineral (barium sulphate,

barite $\mathrm{Ha}_{\mathrm{a}} \mathrm{SO}$, found in Missouri, Virginia, North Carolina and Tennesere, and mined also in Cermany. It is ground to a fine powder and used as a sulsstitute or adulterant for white lead, and as a "filling." in paper. Other harium compounds have minor uses in many inclustries, in which artificially prepared barytes is often a by-product.

Strontium salts are preparel from strontianite (strontium carbonate, Sr $\mathrm{CO}_{3}$ ) and celestite (strontium sulphate, St SO, ), minerals which are found in Cermany, Texas and New lork. Strontium hydrate (or barium hydrate) is used in sugar refuning to assist the recovery of sugar from beet molisises. Strontium nitrate is used in making red fire.

Potash salts (carnallite, kainite, etc.) are found at Stassfurt,

POTASH Germany. Other potasly compounds are obtained by dissolving them wut of wool ashes and from the burnt refuse from sugar beets. Sone potash is also recovered in wool washing.

The compounds of potassium are very similar to the salts of sodium and like them are used in fertilizers, glass-making, soap-making, clyeing and a multitude of other industries.

Sola (sodium carbonate) is found in small quantities in very dry SODA regions, such as parts of California. Ltah. Nevada, Hungary and Evypt.

Soda Ash is the raw commercial form in which soda salts are usually bandled. It is a crude carbonate of soda, generally made from salt by treatment with sulphuric acid and subseguent cabonation. It is useful in making washing solda, baking soda (bicarbonate), caustic sode, in glassmaking and many other inclustries.

The numerous salts of sola are usciul for so many purposes that they cinnut be given in detail. The carbonates are used in dyeing, soap-making, paper-making and wher inclustries. Sodium hyposulphite is used in photonstriby, dycing, and taming soft leather.

Common silt inchueles rock salt, sea salt, and lake salt (balite or

SAL'T sulium chloride, NaCl). Ruck salt occurs in beds or rock numses in the earth and is mined in lumps, like stone or coal. barse mines of rock salt ale located in loland; at many places in Germany and Anstrin; Carrhun, Sprin; Cheshire, England; Jonisiana, Kansas, and many other parts if the workl. In the kuhat Pistrict, India, there is a deposit on a thousind fere in thickness. 
In this country, the greatest salt-producing states are Vlichigan and Xe.

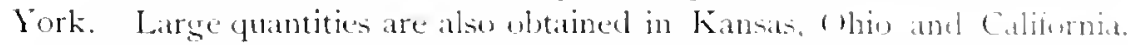
England is the greatest exporter of salt. Salt is manufactured in almost all parts of the world. Owing to its cheapness and wide distribution it is nut as important an article in international commerce as staples which ar. nur. contly and less common.

When a bed of salt exists at a considerable depth, it is often foumb more economical not to work it by ordinary mining methols. In such cases it is usual to bore a well a few inches in diameter to the bed and pumpl water down the well. In contact with the salt, the water becomes a strong brine, which is pumpel to the surface and evaporated.

Much of the salt of commerce is obtained from saline water. ()cean water contains about two and a half per cent. of salt. At Turk's lsland and other phaces in the Mest lndies there is a large production of salt from ocean water. Some lakes, such as the Great Salt Lake and the Deanl Seal, contain a larger percentage of salt than the ocean. Enderground lakes or rivers from which the water is drawn through wells, in some lucalitis yekt strong brines.

The evaporation of saline water is carried on in large open tanks or vats by the matural agency of the sun and wind, or else by artificial heat in evaporating pans. Salt seldom occurs pure in nature, being sorerally

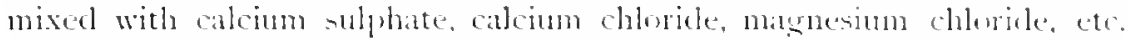
The presence of these other compounds canses it to absort water from the atmospluere.

The oncentrated lifuor from which salt has crystallized nsially contains bromine and indine and is sometimes worked orer for their recorery. The most common commercial silt of boume is potassium promide. Bromites are used in medicines, in photography, and in the manufature of red easin teoul tar colers.

Salt is one of the most important fornds and is marketed in urans of different degrees of fineness. such as table silt, dairy silt, ete. It in nsed for packing meat and curing fish, on account of its preservative plualities. It is used in immense quantities in the manufacture of varions chemicals,

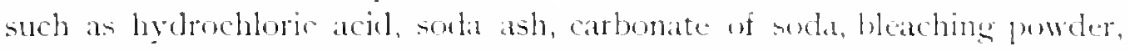
chlorine, chloride of lime, etc, in the refining of sitver and other metal. Jurgical and manufacturing operations. Some of the uses of salt are due tw its property of producing intense cold when mixerl with ice.

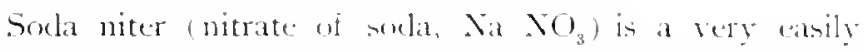

SODA NITER soluble mineral which occurs in inmense beds in the desert region of Atacama, in northern Chile, where rain does not fall for years at a time. The depesits are found at a distance of from ten to twetre feet helow the surfice. The crulle mattetial is transpurted to extensive works on the sea-coast where the niter is dissolved ont with water and recovered in an almost pure state by evaporation. In the purification, other salts and iontine are sepurated. 
Nitrate of solat is one of the chief sturces of nitrogen. $1 \mathrm{t}$ is used in making glass and in the manufacture of nitric acid, a chemial of great imprortance, the salts of which are useful in a multitule of ways. Well known compunds contaning nitrogen, often elerived from soxla niter, are: fertilizers, saltpeter, sunpuwler, fireworks, nitro-glycerine, lynamite and other explosives. Nitrates acur in small amounts in some cares, such as the Mammoth Cave of kentucky.

Nitrogen is plentiful in the air, hut is not in a state in which it is readily aratialse by our present manufacturing processes. Certain bacteria which grow in conlariements on the ronts of lewuminous plants have the unusual property of alborbing nitrogen from the atr and making it available as plint foud. The culture of these hacteria is a rery important part of modern soil tertilizing.

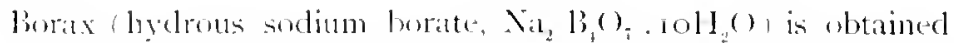

BORAX bye-crytallizing crule natural borax ("tincal", which vecurs in crusts an marshes in central Asia and in Califormia. Nevada and ()resen. Similar depesits acour in Arsentina, Chile, and other parts of Simth America. Most of the berax med in the Linited States in made from colemonite (hyedrous calcium borate. $\left.\mathrm{Ca}_{2} \mathrm{~B}_{6} \mathrm{C}_{11} .5 \mathrm{H}_{2} \mathrm{O}\right)$ ) a mineral mined in suthern Cillifornia. lorates are also foumel at Stassfurt, Germany, and in

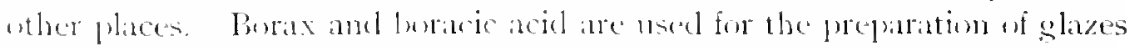
lor puttery and tile, for the manufacture of uptical gliss, in the preservation ai meit, anel for mirus purporses.

Limestone is a rock (essentially calcium cartwonte, $\mathrm{Ca} \mathrm{CO}_{3}$ )

LIMESTONE fomm in leeds af great extent in all parts of the worlel. The purest linestones are white, hut many colors are found senerally ansed by the presene of irom or bituminous matter. In texture linustones vary trom lowse to ompart and from massive to fine or conarse crystolline, Many limestones ane compused al:most entirely of fossil shells. limestone is one of the most important and commonly used luikling stones. It is emplexed also for roadmaking, railowal ballast, onocrete, as thux in smeltins, for making solit and other chemical purposes, in slass making,

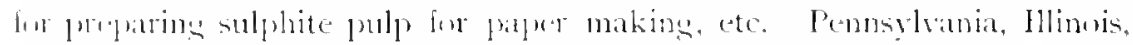

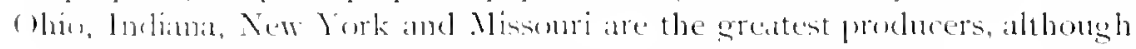
it is pumperl in nearly erery state.

Lime is prolued ly burning or calcining, limestome in kilns. The

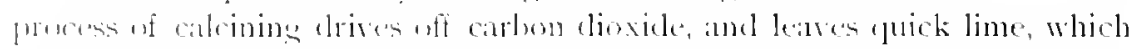

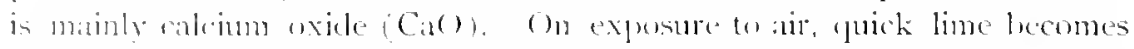

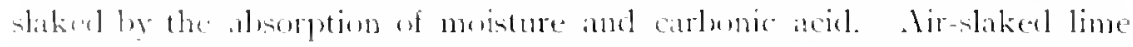

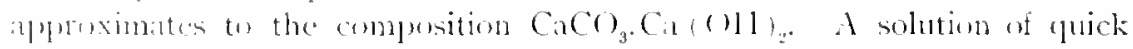

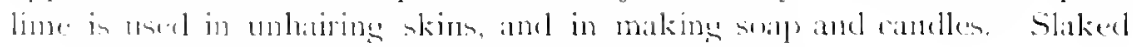
lime is necel as a fertilizer. for purifying coal gas, ats:

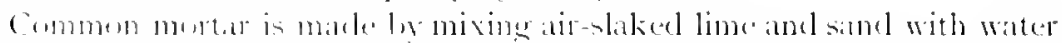

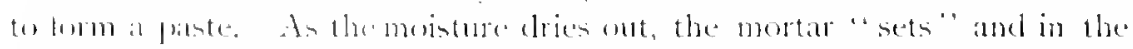

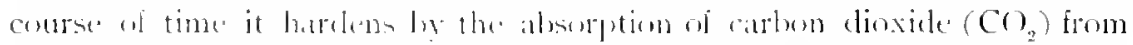

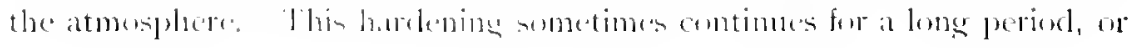


until all the lime is converted into calcium carlonate. Mortar is aencrally strengthened by mixing with it cow hair, palmetto or some other tibur.

Hydraulic limestones when calcined or subjected to heat firld it lime which will set and harden unker water. These limestones all contain silicinus and clayey matter and in burning form certain silicates and alumnates if lime. Ilydraulic cements are unlike common lime in that they do not depend on arying for their setting nor on carbonation for their hatrening. but combine chemically with a certain amount of water and form insolutale compounds. Hydraulic cements are widely used in construction work, expecially in making concrete, a mixture of broken stome with a cemont mortar. Iydraulic cements are often made from other sulstances than hydraulic limestone, such as marls, mixtures of chalk and clay, walcanic tufa and lime, slas and lime, etc.

Portland cement is the most important of the hyrlratic cements. It is prepared from mixtures of limestone, either fure or silicins, with chy. The various substances are pondered and mixed in certain lefinite propurtions. The mixture is thoroughly burned to a clinker, which is afterwarls ground to a finc powder for use.

Chalk is a peculiar soft limestone resembling white das. Mast of it comes from linglanel.

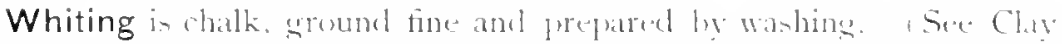
Irashing.) It is alse prepared from some white dass. Whiting in mixed with linseed ail, tw make putty, and is used as an whlterant for wother white pigments in flatuts. Whituwh is smetimes prepared ly mixing whitmes with water and a litteglue, and sometimes by minge sakel lime and water. Whiting (prepared halk or putty purher is also used as at polishing purder.

Marble. Limesumes suitulle for prlishing or for use in ornamental work are callet mathle. The term in sometimes restricted to the white crestalline varietien.

Many kinds of marlole are kmown he the names of the lenalities where they are obtained. Carrara marble in the fine Italian statury mable. Tennesiee matble is a kind extensively used in this conntry for ormamental work. Many different kindsof beatiful marble atre found in 1 taly. Yermont is the

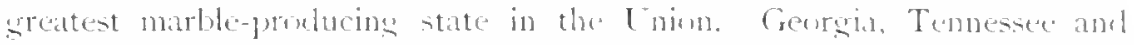
Vew lork proflue large puantities. Marble is also mined in sereral other states. Marble dust and chijo are uned in the generation if carlon dioxide. was CO, for charging sold water and other as rated beveriges.

Mexican Onyx is a tramaluent limestome, with beautiful colors, foumel in many countries and used for ornamental purpuses.

Lithographic limestone is a variety with a very fun texture, found at Solenhofen, Cremany, and uset in making litherraphic plates.

Marl is a calcurenus day gemerally containing the remains of many shells and marine animals. It is sometimes used in making l'ortame rement and wen as a fertilizer. The marl uf Xew Jersey in compund monty uf

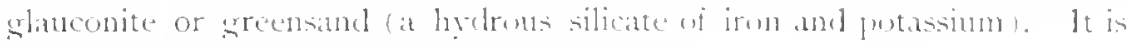
frequently phosphatic and is used an a fertilizer. 


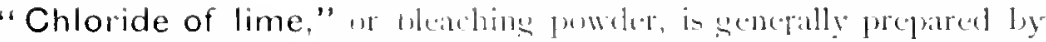
saking line with water and pasing chlorine was over and through it. It is used for l, leaching textiles and palper pulp and for disinfecting.

Acetate of lime is used as a morclant in dyecing.

Calcium carbide is frepared by luatime a mixture of chalk and coke in an electric fumace. When treated with water this substance liberates acetrlene gas, a pumerful illuminant.

Gypum (hritrous calcium sulphate, $\mathrm{Ca} S()_{1}, 2 \mathrm{I} \mathrm{I}_{2} \mathrm{O}$ ) is a soft

GYPSUM mineral fommel in nearly all parts of the workl. In the Lnited States it is mincel in Michigan, Kinnsas, New York, Ohio and other states. A consilerable quantity is imported from Canada. Beds of salt are usually foumd near gypsum.

Plaster is prepared by calcining gipsum, a precess which cunsists in leating it, thus driving off some of the water which it contains. When phaster is mixed with water, they combline again to make grosum and the minute crystals of this substance in forming, interlace and cause the plaster tw "set." The purest calcined gypsum is called "plaster of paris." Wall plaster is less pure, contains sand and fiber, and hes not set so rapidly as plaster of paris. Impure gyoum is used in making land phaster and other fertilizers. l'mwlered eypsum is used as a "hading" material in paper nuakinn.:

Alaba ter is a compact, pure white variety of sypum used for ornamental purjoses.

Fhurite (calcium furoride, $C$ a $F$ ) is used as a flux in the FLUORITE reduction of some ores, in the manufacture of opalescent glass, ir the prexhetion of helrofluoric aciel and for minor purpuses. It is obtaned in kentucky, southern lllinois, and at some places in burne.

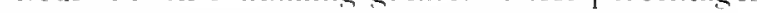

PHOSPHATE ROCK of phosphate of lime, lisually associated with carbonate of lime, oceur in various patts of the world. Some of these phosphatic beds consist of linestone, carrying a small percentise of calcium plosphate, and such are not asailable as a commercial source of phosphorus; some depusts are composed largely of thone and wher orsunic remains, and some are of a distinctly roprolitic nature. The phomphatic character of these beds is traceable in most, if not all, cases to an animal arigin.

The leprests near Charleston, S. C., are distincty composed of oreanic remains and contain many shark's teeth, bones, and the remains of marine animals.

The phosphate rock of 'Tennessee is ensentially it linestone from which much of the calcium cirlonate has been dissolsed.

other phosphate berls acur in Foricla, the West lodies, Canada, Es-

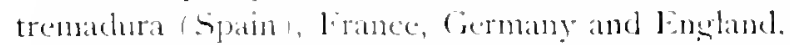

In Canade depusts of limesone contain a crystalline mincral called apatite (a calcium pluaphlate). 
Natural phosplates are used in the preparation of leatilizers, for which purpose they are usually treated with sulphuric acid $\mathrm{H}_{2} \mathrm{SO}$, , which converts the lone phosphate $\left(\mathrm{Ca}_{3}\left(\mathrm{PO}_{4}\right)_{2}\right)$ inte superphosphate (a mixture wil calcium sulphate with the aciel phosphate ol lime, $\left.\mathrm{CaH}_{4}\left(\mathrm{P}_{(}\right)_{4}\right)$ ). in which form it is much more easily solulle in water, and hence more available as plant food. The natural phosphates are also used as the source of phosphorus for the manufacture of matches, phosphoric aciel and various compounds, such as phosphate of sola used in dyeing.

For other fertilizers see Guans, l,ime, Gas Lime, Fish, Nitrate, Slas, etc. Wiastes such as garbage and sewige when worked up by modern processes yield valuable fertilizers, with otlerer products.

Sulphur, or brimstone, wceurs in a pure state in various parts

SULPHUR of the worlel. It is found abundantly in the neighborlomel of active or extinct volcanoes, and is frequently associated with beds of gypsum and limestone. It occurs impresnating the water of sulphur springs, and, in chemical combination with varions metals, is an inportant constituent of the large class of compounds called sulphides, which embrace many of the important metallic ores. Native sulphur, pyrite and the waste calcium sulphicle from alkali works are the chief sources of sulphur compounds. The island of Sicily is the greatest commercial sonret of native sulphur. The mines there have been worked for ma y hundrets of years. Sulphur is found in Italy, Japan, Hawaii and other places. In the Enited states it accurs in I,ouisiana, Nevala, California and Etah.

In sicily it is partly purified ly piling the rock in heags and ienriting it, the heat produced by the combustion of some of the sulphur melting the rest which runs down and is drawn off from the bottom of the heap. Crucle suphur is distilled to make "funers of sulphur" and "roll brimstune."

Sulphur is commercially useful in vulcanizing rubber, for heaching, for the manufacture of gunpoweter and matches, for medicinal purposes, ats at disinfectant, and for the preparation of many empoume which contain it. The most important sulphur compound and the one through which most of the others are derived is sulphuric aciel, which is prepared from sulphur in much the same way as from prite.

Sulphurous acid is much like sulphuric and is most used in making paper pulp, in bleaching and disinfecting.

Some of the well-knom onmpounds which are derived from sulphuric acid are: blue vitriol, copperats or green vitriol, and alum. Sulphuric acid is used in purifying petroleum, regetalle and animal cils, in the manufacture of the aniline dyes, and the very numerous chenical compounds cmbraced in the groups called sulphates and sulphites, the nanes and uses of which are too mumcrous to specify.

Bisulphide of carbon is a volatile liquitel userl as a solvent for rublet, sulphur, phosphorus, resins and oils. It is also employed as an insecticide. especially in wheat elevaturs. 
Quartz (silica, Si (), is one of the most common minerats in QUARTz all parts of the world. It is found in rock masses (quartzite); in sands and sandstones: also as clear, transparent crystals (rock crystal). Virieties occur of many shades of color, milky, amethyst, rose, yellow and smoky. Other non-crystalline kinds are found in great variety, such as agate, moss asate, onyx, sardonyx, chalcedony, carnelian, chrsoprase, prase, heliotrope, at's eye, tiger's eye, jasper, tlint, chert, homstone, honestone, touchstone, buhrstone, petrified or agatized wood, etc. In addition to forming sandstones and quartzites, quartz occurs as a constituent of many rocks, such as granite. Nany rarjeties of quartz are used in jewetry and for making ornamental articles. Rhinestones and lenses are cut from clear crystal quartz.

American rock flint is pure quartz rock which is crushed and used for pottery and glass making. It is mined in Connecticut and Pennsylvania.

Glass sand is ohtained in Pennsylrania, Ohio. Illinois, Mest Virginia, New Jersey, Missumi and other states.

Ouartz sand and yround fuartz are used in sandpaper, sandsoap, polishing poweters and saml blasts. Sand is used as a refractory lining in furnaces. Sond is also used in making moulds for casting metals, for making filter beds, for sanding railroal tracks, for mixing in asphalt for paving, and in cement and mortar for building.

Flint is funnd in irregular nodules in chalk or limestone. The supply comes from lingland, France and freland. It is chictly used in pottery making, being ground to a fine powder, and mixed with clay and feldspar. Arrow points and knives were made of thint by primitive peoples. Flint was used with steet for making tire before the invention of matches.

Sandstone is a sedimentary rock composed of grains of quartz comented tenether in a coherent mass. The cementing material is sometimes silicions when it furms a hard and durable rock. Sindstones nocur in many shates of white, yellow, red and brown. They are found both loose and inmpract, and fine and coarse grined. They are used for millstenes and grindstones, for building, road making, railroad ballast, concrete, etc. Some sandstones ate crushed to make glasis sand.

Pennsyluania, Ohio and New lork are the greatest producers of sandstone in this cenntry, but it is quarried in almost all the states. Pennsyliania and Yew York produce a variety called bluestone or flagstone, used for parims. Buhrstune is used for millstones. Honestones, oilstones, whetstomes and other sharpening stones are mosty made of sandstone. Arkansas (nosaculite), Michigan, Indiana, New Hampshire and Vermont produce mut of these articles.

Glass is made hy fusing a mixture of silica (glass sand). alkali

GLASS (generally soda ash , and lime. This mixture makes lime glass.

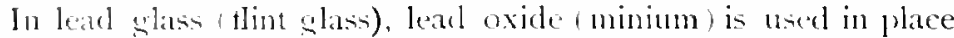
of the line. Sodium sulphate and potah are sometines used insteal of suda ash, and salts of other metils instead of the lime or lead oxide. Lead gram is somewhat softer and mere combly than lime glass, hit is generally 
clearer and more brilliant. It is used for fine grades of glassware, particulariy for cut glass. Artificial sems (strass) contain a very large percentage of lead. Small amounts of iron in the materials used, give a green color to glass. This is usually corrected by adding manganese dioxide to the mixture. Colored glass is made by adding salts of iron, copper, cobalt, or other metals.

The mixture of powdered materials called "glass batch" or "frit" is melted in a clay pot or tank in a furnace. Nost articles of glass are blown by means of an iron tube about five feet long. A mass of molten ghass ("metal") taken from the melting pot on the end of the tube, is expanded by hlowing and shaped while hot into almost any desired form. The shaping is often done by blowing in moulds of clay or iron. Window glass (cylincler or sheet glass) is blown into a large bulb which is rolled to cylindrical form and then cut open and flattened out. For crown glass a bulb is blown, opened at the end and extended into a sheet hy rapid rotation. Cheap glassiare is blown by machinery.

Many articles of glass are not blown, but pressed in moulds, and others are mate ly a combination of blowing and joressing. Pressed glass is uften marle to imitate cut glass.

Plate glass is made by pouring the molten glass on a smooth iron table over which a roller passes making the glass of an even thickness. Later it is ground that and polished with sand and rouge.

All glass must be annealed to prevent brittleness. This is done ly slow and equal cooling either in a kiln where the process takes several days on in an annealing lelur or oven where the glass passes on travelling bands in a few hours, flurough a gradually diminishing temperature.

Cut glass is produced by pressing the article against a revolving grindstone and pulishing on a wheel fed with emery and rouge. Glass is ornamented in other ways hy staining (painting) and re-beating. by engraving with a small revolving wheel, and by etching with hydrofturic acid.

Glass is used for a great variety of purposes, among the most important of which are window slass, mirrors, bottles, fruit jars, lamps. chimneys, globes, incandescent lamps, tumblers, dishes, lenses, tiling, etc. For skylinhts aud places exposed to danger from fire, ylass is made enclosing a network of wire.

Belgium, Austria, Germany, France, and the United States are the leading manulacturers of glass. In this country Pennsyliania, Indiana, New Jersey, Ohio, Illinnis, New York, West Virginia and Missouri are the greatest glass-making states. The abunclance of natural gas in certain sections, wiving a cheap and desirable fuel, has greatly influenced the location of glass factories.

Opal for gems is found in Austratia, Mexico and Hungary. A

OPAL few opals have been found in Iaho. Opals have almost the same composition as quartz. 
Infusorial earth (diatenancenss earth on tripoli) is formed of the silicious sluells of a multitute of microscopic organisms. It has essentially the sime composition als opal. It is a light, porous, clay-like material found in Tripoli. Tuscany. Virginia, Califurnia, and many other localities. It is used for making polishing powders (electro-silicon), scouring soap, packing areund lovilers and steam pipes, as a base for fireproof cement, plaster and brick. It has been emplued as an absurbent of nitro-glycerine in the manufacture of dynamite, hut for this purpose is replaced by wood pulp.

In addition to the diamond, sapphire, ruby, opal and the many

GEMS varieties of quartz used for gems, there are other hard minerals, mostly transparent, used in juwelry. Among these the most important are topaz, emerald, aquamarine, beryl, tourmaline, olivine, chrysolite, spind, monnstone and turquois. In the island of Ceylon, precious stunce of many varieties are found in gravel. In this country, beryl and amethyst are found in North Carolina and Comecticut, turquoise in New Nexico, Arizona, Nevada and California, sajphire in Montana, toumaline in California and Maine, chrysoprase and kunzite in California, and garnet in Arizona, New Mexico and North Carolina.

Garnet is mined in North Carolina, Pennsylyania, New Yorkand Connecticut in opaque masses unfit for gems. It is a trifle less hard than quartz and is an importunt abrasive used for making wheels, paper and polishing powder.

Vica is a common mineral which occurs as a constituent of granite.

MICA It splits readily into very thin sheets and is of value commercially only when it occurs in slicets with an area of at least several square inches. India is the greatest producer of mica. There are important deposits in Canata, North Carolina, South Dakota and Virginia. Two important varietics are found, viz., clean transparent mica (muscorite) and opaque or (lark colored mica (biotite or phlogropite). For panels in stove doors, and chinneys of incandescent gas lamps only the transparent kind is used. Sheet mica is also employed in electrical work for insulating. The scrap mica and trimmings from sheets are ground up for use in lubricating heavy machinery, and for making insulators and pipe covering. Ground mica is aloo used for griving a spangled or frosted effect to wall paper.

lsinglass is not mica, but a pure sheet gelatine prepared chiefly from the swimming bladders of fish. (See lsinglass.)

Building stones are generally quarried in the neigh-

BUILDING STONES horhood where they are used, and only in special cases enter into general commerce. They are used for construction of walls, ornamental work, monuments, loundations, pavements (in slabs and paving blocks), curbstones, flagstones, etc. Exceptionally beautiful marljes and granites are shipped to a distance for the construction of handsome buildings, monuments, or interior decorations.

(See also, Limestone, Marble, Sandstone, Slate, etc.)

Stone of the same general nature, in smaller, irregular pieces, is used in the form of rubble and crushed stone for roadmaking, concrete and railroatl ballast. 
Granite is a name applied commercially to ahmost all ignerous

GRANITE rocks. Typical granite is a mixture of interlocking pratims of quartz, felelspar and mica. In gneiss, the same ninerals are arranged in layers. In syenite, hornblende takes the place of the micat of granite. Quartz-porphyry, andesite, mica schist, diabase, diorite, basalt, trap, and gabbro are all generally includerl in the class of granites. The latter of these rocks are chichy used in the form of rushed stone for paring.

In texture, granites vary from extremely fine to very cortse grainerl, and in color are white or grayish, red, yellow, brown or green, depending generally on the color of the feldspar. In quarying, blocks are lowsened by taking alvantage of natural joints or seans and by following certim directions along which the rock splits easiest. Granite is a very hard, strong, and clurable rock, susceptible of a high pulish and much used for building construction and ormamental work. In this cumtry the states producing the most granite are Nassachusetts, Naine, Vermont and New Hampshire.

The hydrocarbon group embraces coal, asphaltum, HYDROCARBONS petroleum and natural sas. These have all restulted from the decomposition of organic matter in the earth. Vegetable matter has been the must important factor in their formation, fossil plants being a prominent feature of many coal deposits. In some cases, however, such as certain petrolemo and asphalts, it is hichly probable that they have been derived, in part at least, from marine or uther animal remains.

Porous rocks, such as sandstunes, limestones and shales, not infrequently contain small pereentages of bitumimus matter. The coloring matter of most black marble is of this nature, amel was probably derived from the animals, the shells of which furnish the lime of which the ruck is composed.

The form in which these carbon compounds now acour depends on the conditions under which they were deposited, and the influence of time, heat, pressure of superincumbent rocks and other agencies to which they have since been subjected.

Coal is the fuel upon which modern manufactures are absu-

COAL lutely dependent. It is in general the result of the gradual change which has taken place chring past ages in organic aleposits. chiefly veretable, and its form and composition depend upon the extent to which this change has gone on. Thus it passes from forms, such as peat and lignite, which still retain the structure of the vegetalle matter, through those with bess of the volatile or hituminous ingredients to anthracite, anu, further, to kinds which approich sraphite. Varieties are found intermediate between all the various important types.

The most important coal-producing states are Pennsylamia, Oho, West Virginia, Alabama, Jukliana, lowa, Colorarlo, Kansas, Kenturky aubl Mlaryland. Deposits are worked to some extent in most of the stalea and territories. 
There are important depesits of coal in Wales (somed which is anthra. cite), in England. Germany, Austria, Russia and Australia. Other deposits, many of which are mined and which may be of greater future importance, occur in Mexico, South Anerica, South Africa, India, China, Japan and the Philippines.

Peat or turf is a transition state between unaltered vegetable debris and brown coal. It is formed in bogs and swamps by the partial alteration of leaves, moss, wood, roots, etc., in masses out of contact with the atmosphere. beds of peat are of comparatively recent origin and contain more or less unaltered vegetable fiber. This is sometimes extracted and made into mats and packing material. Peat is sometimes made into coke and the gases derived from it in coking yiekl a rariety of products. Peat is a common fuel in Holland, Ireland and Russia. Nuck from peat beds is sometimes used as a fertilizer.

Brown Coal is a more compact variety, usually brownish-l)lack in color, 1t contains considerable water and 20 per cent. or more of oxygen. lignite is a brown coal which retains the structure of the original wood from which it was formed. Brown coal and lignite are mined in some parts of Germany and Austria, and in other countries.

Bituminous Coal, or common soft coal, generally contains from 5 to 15 per cent. of oxyen and 4 to 7 per cent. of hydrogen. There are several types of lituminous coal, the most important of which are:

Caking or Coking Coal, which becomes pasty or semi-riscid in the fire and loses its volatile gases before the combustion of its fixed carbon.

Non-Coking Coal is similar in appearance and composition to coking coal, but burns freely, without softening, or any appearance of fusion.

Cannel Coal (parrot coal, horn coal) is a compact bituminous coal which yields to per cent. to 60 per cent. of volatile matter. It is used in sas-making.

Cherry or soft coal, splint or hard coal, free-burning, hinding, hlock, gas and steam coals are names applied to rarieties of bituminous coal.

Sunc kinds of coal are used for special purposes for which it has been found that they are best adapted, such as coke-making, steam-raising, gasmaking, smelting, etc.

Anthracite Coal is a hard coal containing a high percentage of carbon and a low percentage of volatile matter. Semi-anthracites are a stage between hituminous and true anthracite coal.

In the Lnited States, Pennsylvania produces almost all the anthracite and leats in the quantity and value of bituminous coal, the output of this alone being three times that of Illinois, the state which stands next in importance. The value of the anthracite coal produced annually in Pennsylvaniat is almost equal to that of all the gold produced in a year in the United States.

In the mining of coal and its preparation for market by breaking to various sizes (known in this country as steamboat, broken, heater, egg, stove, chestnut, wea, buckwheat and rice), there is produced a great deal of 


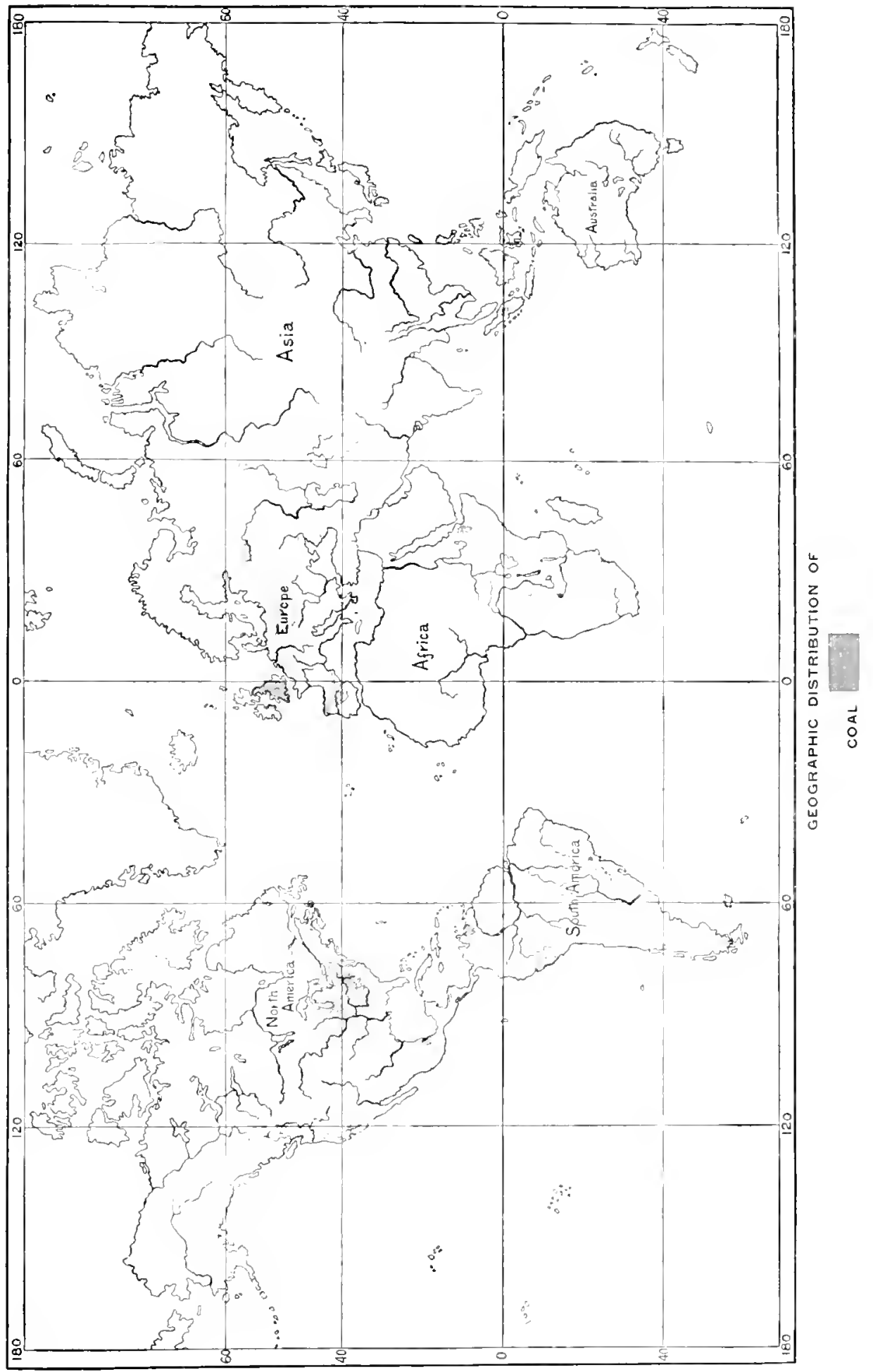



fine coal dust, slack or culnt. This used to be piled up in great herith ne:in the mines and was comsidered valueless. Considerable of it in now brin: used in firing boilers, and is burned in specially constructed grates. It is also used in makingr coke. Wuch coal is separated from pyrite, clay, slate and coal dust by washing, washeries being often connected with the breakers.

Coke is a fuel prejared from coking coal by partial combustion in ovens. The heat drives off the volatile matter and the sulphur which is often contained in the coal. Coke is of great use in metallurgy, particularly in iron smelting, because of its porosity, its resistance to crushing and its comparative freedom from sulphur.

When coke is made in specially constructed by-product ovens, some of the gases which are driven off are burned under the ovens to aid in the coking, and ammonia and coal tar are recovered. In many places in this country these valuable by-products are allowed to go to waste.

Coal gas or illuminating gas is produced by the distillation of coul in retorts. The gases which come off are purified by passing through water which dissolves the ammonia which they contain, and then throush slaked lime which absorbs sulphur, cyanogen and carbon dioxide. After several re-burnings the lime contains consideralde calcium sublate and is solel as gas lime for fertilizer.

Water gas is made by passing steam over a bed of red hot coke. It is used for fuel. For illuminating, it needs to be enriched, as does also some. coal gas, by mixture with benzenes or other volatile products.

The thick, viscous coal tar is distilled and its products re-distilled, and treated with suphuric acid, caustic alkalis and other chemicals. They yidet a sreat variety of useful articles, as will be seen from the accompanying diagram. There are thousands of compounds from cual tar, a list of which woukl simply be an enumeration of unfamiliar names. The dyes itone number several hundreds and are known as anlines, anthracenes, alizarines, eosine, ete., and are of all colors and shades. This table simply gives general groups of substances with their uses. (Ammonia is also obtained from many other sources.

(See also Wood Distillation.) 
$\frac{8}{8}$

0
0
$\pi$
$m$
$\frac{0}{0}$
$\frac{0}{2}$
$\overrightarrow{0}$
$\frac{0}{0}$
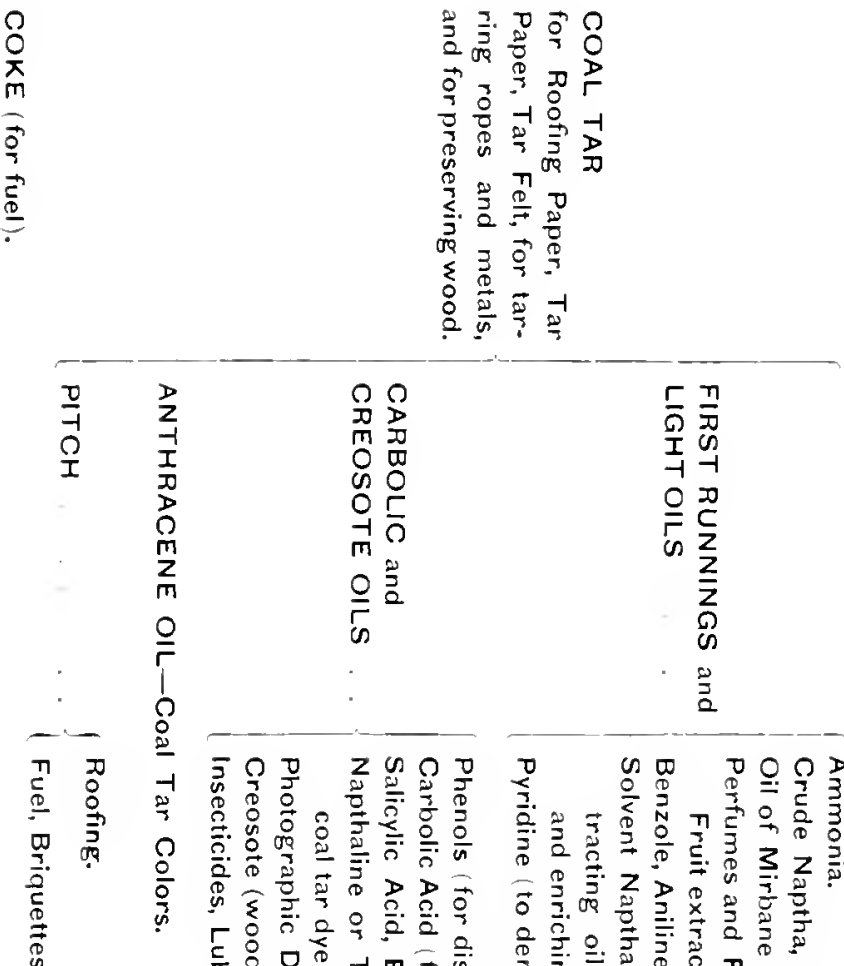

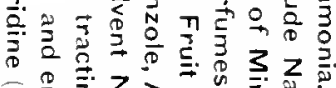

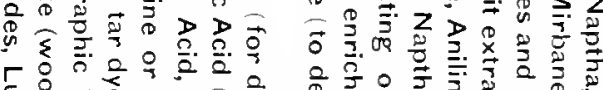

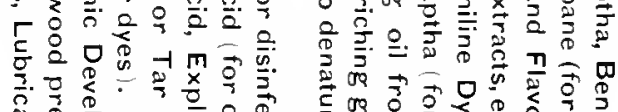

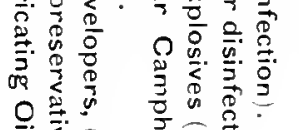

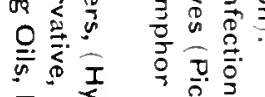

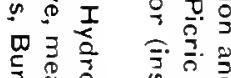

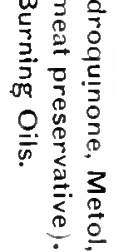

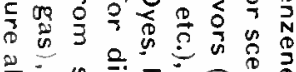

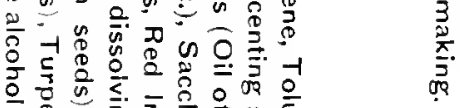

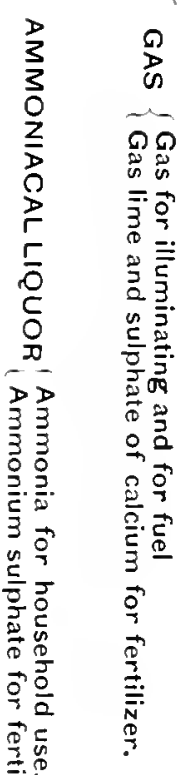




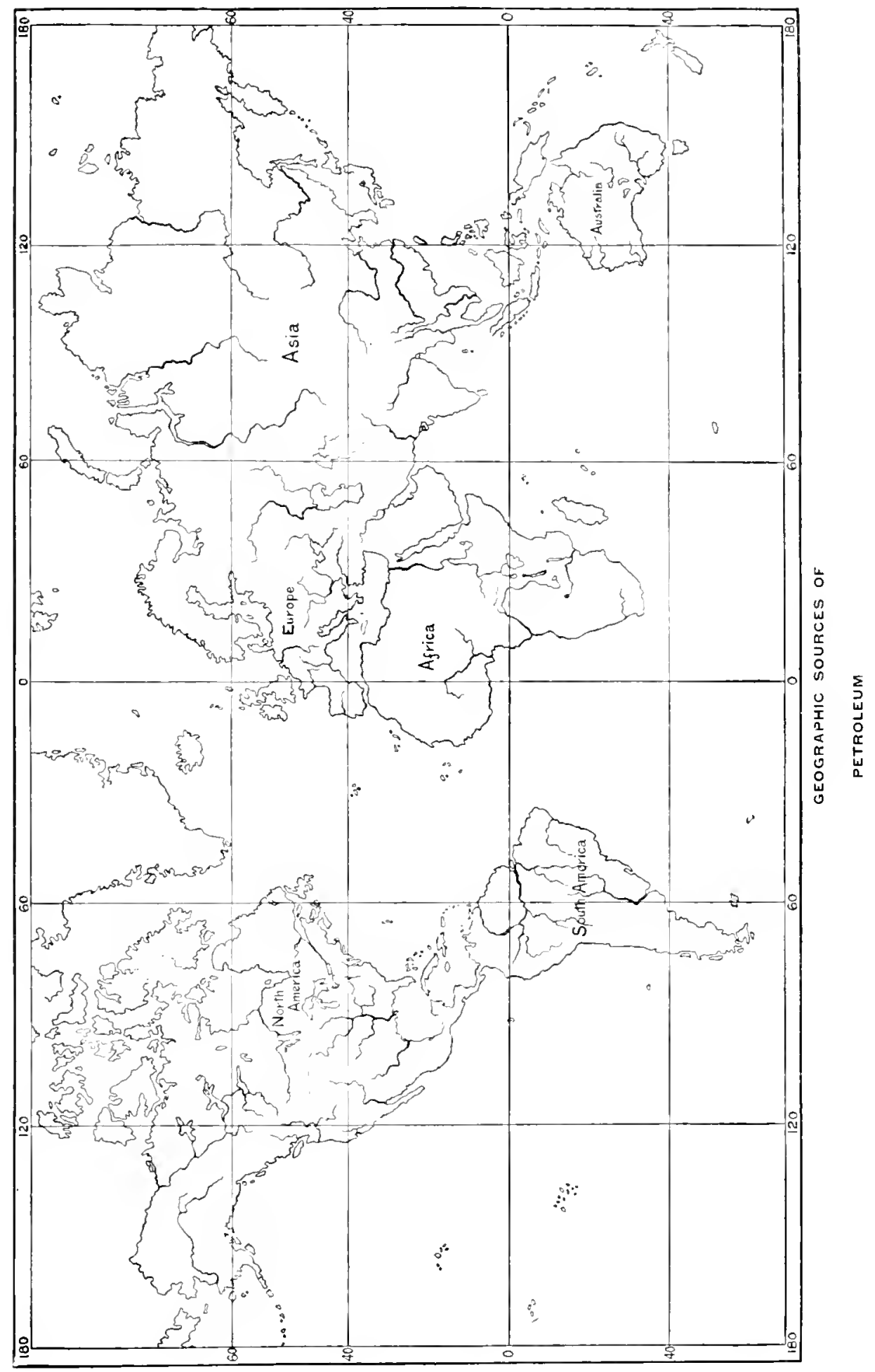





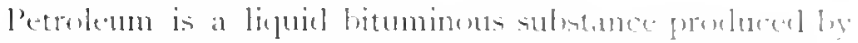

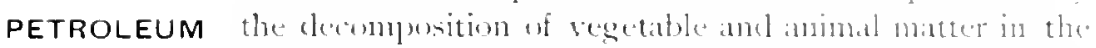

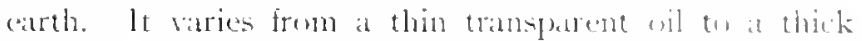
viscous liquicl. Petroleum is found in emormous guantitics saturang beds of sumbtone, conglomerate, shale, or other porous rocks. brine in almust

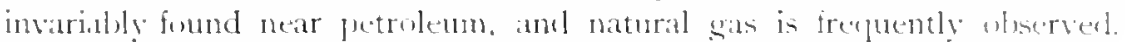
Most of the petroleum of commerce comes from the regrom of ohio, IVest Virginia and western Pennsylyania, and from Baku, on the Casplian Sead de is prohloced in Texas, Indiana, California, Colnotw, Canatla, and in fallicia, Sumatra, Jara, Cpper Burna, Rommania, Jatran and Pert. The Lnitexl States is the areatest producer of illuminating oils, the yichl from the crute oil areraging 75 per cent. while the Russian crude oil yiddsonly almut 35 per cent. of illuminating oil. The Rusian crule oil and the Texas crute wil are furticu la:ly useful as fuel wils. On distillation the Russian oil yelets much napthaline.

Petrolem is oftained from wells a few inches in diameter, smo through the earth to the porous strata where the oil wocurs. The wells vary in depth from a couple of huncted feet to as much as three w fom thousand feet and are bored by means of long heary drills. Derroks built ower the wells support the drilling tools. The machinery is nperated by steam engines which raise the drills a few inches and alrop them, their sharp chisellike ends and heary weight causing them to lrive a hole slowly through very hard rocks. The wells are ustally lined for at least a part of their depth witly cast irm pipe. Mells for natural gas are borted in the same way. Wells which (lo not How freely are often made to yich large quantities of wil by expluding nitro-glycerine in them. This is called "shomting " a well.

The crucle oil is usually transported on land, by pumping threush pipe lines. The pipes run for hundreds of miles from the wello tor refineries usually located on the sea coast. From the coast, oil is shipperl in tank steamers to other comberies. Oils are shipped ly rail in tank cars. Enormous quantities of refined oil are handled in this country and experted te all parts of the work in larese square tin cans. Nany forejun comntries levy

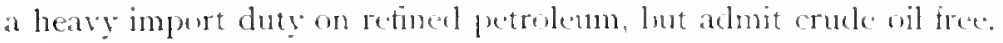

Crude petroleum is retined for use $\lg$ heating it in large ontaniners. The rapors which distill off are cundensed hy couling. In this way it is separated into various "fractions," some of them light and easily wolatile like gavoline, maptha and benzine: some a little hearier and lens volitile, such as kerosune, headlight, and other illuminating oils: and some still hesuler oits used for lubricating. The fractions are further purified by treatment with sulphuric acid and caustic soda and by re-distillation. The many araden of refineal products are found uscul for various purposes, such as fuel, illuminating wil. lubricating oils, wils for gis making, sulvents for rubber, renins, ete, turpentine substitute, wolatile oil for ice making. flemer oil, amel for a large number of other uses.

Vaseline, petrolatum, or uther semi-solicl greaties are extricted from illuminating oils luring the refining process. Vaseline is uneel in ointments and for lubricating. 
Paraffine wax is seprarated in the prurification of the fubricating wils. Paraffine is similar in appearance and in many of its properties to bleached becswax. It is used for waxing floors, waxing pajer, making candles and as a substitute or adulterant for other waxes. Ozocerite (native paraffine) is found in Galicia and is used for the same purposes, also for insulating, and waterprooling electric wires.

Lubricating wils for all sorts of machinery are prepared ly mixtures of petroleum products with vegetable nils. The residum after distillation is a thick substance similar to asplaalt in its nature. It is mixed with asphalt for paring, or with coal dust is mate into briquettes for fuel. When the distillation is further continued, petroleum coke results. Electric light carbons are made of petrolenm coke.

Asphaltum (mineral pitch) is a bituminous mineral subASPHALTUM stance formed by the decomposition of organic matter. It varies in consistency from liquid or viscous varieties (callet mineral tar or maltha) to hard, brittle, solicl asphaltums.

Petrolemus change to asphaltum hy oxygenation and the loss of their volatile oils. Asphaltum is found in small quantities in a state of high purity, and occurs in larger deposits mixed with earthy matter or impregnating beds of porous materials, such as clays, shales, sandstones and limestones. These latter varieties are called rock asphalts.

The most important commercial source is the Pitch Lake on the Island of Trinidad, which funishes an asphalt containing about fifty-five per cent. of bitumen, with thirty-five per cent. of earthy matter. Asphalt is also found in Venezuela and in several of the West India islands, notably Barbados and Cuba.

In the Enited States, pure varieties (ozocerite, gilsonite and uintahite) are produced in Ltalı and California, and rock asphalts are mined in considerable quantity in California and to a much less extent in Kentucky and Indian Territory. In France and Switzerland there are large beds of asphaltic limestones which are used for paring. There are similar deposits in Germany, Italy and Spain.

The most important use of asphalt is as a paring material. Asphalt parements are made of broken and pulverized rock and sand held together by eight to ten per cent. of asplatic cement composed of a mixture of asplualtum and petroleum residum. Asphat is used as a cement between wooden paring blecks. Ithen mixed with broken stone and sand it is compressed into asplatt paving blocks. Pure rarieties are used in making black varnish for metals and leathers, for insulating, for water-proofing and for cement in construction work.

Amber is frecuently classed as a mineral among the hydro-

AMBER carbent. It is a hard lossil resin, found along the shore of the Jaltic sea. Small quantities come from Sicily and other localities. It is carred inte fancy articles, such as mouthpieces for pipes and cigar holders, leads and the like. The sharings and small oparge pieces are useal in making finc varnish. 
Graphite (plumbage or black lead) is a purer form ot rat

GRAPHITE bon than conl. It has essentially the same compusition as the diamond. It is called black lead because, like the metal lead, it will leave a mark on paper. The principal sources of supply ar. Ceylon. New York and Bohemia. It is also found in Camada, Nlexion and some other localities.

The best or crystalline grades of graphite are used for making crucilses, lead pencils, and lubricants for chains and heavy machinery. The puset grackes are employed for stove polish, foundry facings, paint, etc. Craphite crucibles are used for melting precious metals and other substances that must be exposed to a high heat. They are made by moulding and baking a mixture of graphite and selected day.

The lead for pencils is prepared by grinding graphite, separating the funest powders, generally by floating them away in water and allowing them to subside. The very finest powder is used for the high grade pencils. Clay is also prepared by floating and is mixed and ground with the graphite in greater or less proportion, the hardest pencils containing the most rly: After the mass is monlded in the shape of leads, it is laked in a kilu and later glued between strips of eedar which are shaped as desired.

Foundry facings are put on the surface of sand moulds to frerent the metal when cast from adhering to the sind.

Graphite is also used in glazing purter srains and shot. Graphitu made artificially at Niagara lablls, by an dectric process from anthracite conl or coke, is used for making electrokles, cathons, paint and foundry facings.

Diamonets are found principally in Sumb Africa. A kew

DIAMONDS are obtained in Brasil and smaller mumbers in inclia and some other parts of the worlel. The dianond is the hardest knum substance and is composed of pure crystallized carboun ( C), an dement found in almost as pure a state, in the form of araphite and less pure as coal. Carbon is a necessary ingredient of all living ureanisms.

Clear, flawless diamonds ate valued at : aems on account of their rarity, hardness and high refractive power. No other substance being so harel, diamonds are cut and polished by the use of cliamonel dust. Amsterelum and Antwerp are the headquarters of the diamond-cutting industry.

Some diamonds are black in color and many are small, not transperent, or of such poor quality that they are useless as gems. These are used for polishing or for cutting hard substances. The llack ones (carbonato or bort) are a tritle hareler than transparent diammols and are used in diamond 1:ills. For this purpose they are momuted on the end or eclare of a metal tube two or three inches in dianeter. This is resolved ly machinery and pressing on rocks below the earth's surface rapielly grinds or drills a hole. The cores of rock obtained from such wells give valuable information as to the nature of rocks and mincral clepusits hathe the surfice of the warth. Most wells for oil, water or brine are driven as described under petrolem. 


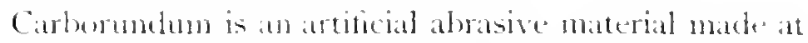

carborundum Nitgua Falls, X. Y., hy fusing a mixure of coke, saludust and simet in an electric furnace. Chemically it is carbide of silicon $\mathrm{SiCl}$. Its hardness is greater than that of any other known substance except the diammel. Like other almasives it is used in the form of powders of elifferent chegrees if bineness and for making grinding wheels and sharpening stones.

Pumice is a volcanic rock, solter than most wher abrasives.

PUMICE $1 \mathrm{t}$ is used in hump and in poweles for polishing metals, stone, wood and varnish. Almost all of the pumice usted comes from 1.ipari, an island off the north coast of Sicily.

Rotten stone is prepared from decumposed rocks.

ROTTEN STONE It is a fine smonth puwder, not of great hardness. it is much used for rubling down and polishing rarnishecl surfaces.

For other abrasives see Quartz, Corundum, Garnet, Rouge, Infusorial Earth and Putty Powder.

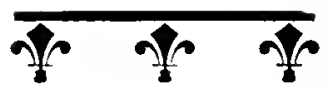




\section{CONTENTS}

\section{LIST OF ILLUSTRATIONS.}

The Cotton Plant and its Products.

Threshing Wheat, Minnesota

Frontispicere

Picking Coffee, Brazil

Cucmonut Trees, Jamaica

Hydraulic Gold Mijung, New Ztalamel.

\section{LIST OF DIAGRAMS.}

Corn I'lant

Coconnut Paln. . . . . . . . . . . . . . . . . . . . . . 24

Cottun I'bant. . . . . . . . . . . . . . . . . . . . . . . . 25

Pine Tree, s.llow . . . . . . . . . . . . . . . . . . . . . . 32

IVood IJistillation . . . . . . . . . . . . . . . . . . . . . . . . 47

Coal Distillation..... . . . . . . . . . . . . . . . . . . . . . . . .

MAPS.

Ash

opposite 42

Banana

becects

birch, hlack

Cican

Cattle llides

Cherry.

Chestidu

Co.1

Cincianut

Cinffer.

Cork

Corn, Indian

Ciston. . .

Cypress, bald.

IAlomy

Ein, white

fucalyptus

Fir, I bouslas

Folix

Goat and Kid Skins

riolel

I emlock

Ilemp, Sisal, Manila.

I Iickory

Mides, Cattle

Iron

Jacarandal. 
Jute

I"Ar.

Mprosite 2 "

Mahogatis

(" 42

Maize.

Minple-sugar.

(ak, white, old Wiorld

(hak. red. cork

11 4

letruleam

Fine, white, yellow

kice.

kessemand

kiubber .

sheer .

silk.

silver.

Spruce, white, hlack, Norway, common . . . . . . . . . . . . .

sugar, cante, beet.

sicialmote

Teia

Feak.

IIInlunt

Wheat

11 oul.

INDEX TO SUBJECTS

\section{A}

Abacia

Abitone.

Alitivives

Acetater

Acetone

Acetylente

Aciel.

Acid. acelic

icid, tellzono

Acul, boracic

Acri, carloolio

Acil clirumic

Acikl. cresslic

Acid hydrochloric

Acikl hivelrothoric

Acid, nitric

Acia, oxilic

Acid phosphurio

Acil, pierk

Acid, Integallic

Acil, pyrolientorin

Acid, salycilic

Acid sulphuric

Acil stlphuru

Acilitar

Agin-agit

Agite

An:ale

Alatrialet

Albtumen, libond

Albtumen, tegr

Alonhol

Alolublic liquors.

Henthol, woud

Aleter

Algurolitla

Alizarine

Allizatos

Allow

- H1-jice

Aluce filer

Alutes

Aljaca

Alinin.

Alu111inis

\section{' Aluninimu}

Alunininn lironze

1]utuinum

inuluin

dunite.

Amalgan

Amber

nilibergris

hinethysil

Anmonia

Ammonian sinphide

Amunominn

inderite

Angora

Anilne Animal products

indme

Anise

Anuatio

Antelope

Anthracene

Antliracite.

Anti-frction inetal.

Aistinony

Apatile

Aytiofuatine

Arbor ritite

Areca

Argentiferons ores.

Argentite

Argol=

Arrica

Arrack

Arsenic

Arsenopy rite
Artificial silk

- safecticla

Asbestos

Asbestil=

Ash.

Ashes

Asphialt

Asplialtum

Asirite
Antipsrive

Arrowroot

PAGE

6,23

45

is

4,45

106

70,54

$94, \sin 0$

$47.103,104,00$

2
$-\quad \infty$

in 101

$10 \%, 104,47,95$ 5it to 75,90 49

49
15
00

st

10 3. $\tan$

$102,101,107$

$84,80,81,5,50$

. . . 16

9

100

37

37

4

55,55

23, 24

qi, 85,16

. or

29,17

41

40,17

40

$100,94,801,104$

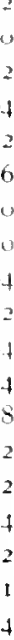


B

\begin{tabular}{|c|c|c|}
\hline \multicolumn{3}{|l|}{ Bilcteria . } \\
\hline Balblitt metal & & . . \\
\hline bialger. & & . . \\
\hline Buking foud & ler & . \\
\hline Jiblibta & . & . \\
\hline $\begin{array}{l}\text { Bulletul } \\
\text { listhathis }\end{array}$ & . &. \\
\hline Binnluto & & \\
\hline Hamana. i & . & $\cdot \cdot$ \\
\hline Bulluma ail. & & · $\cdot$ \\
\hline $\begin{array}{l}\text { Barite } \\
\text { Birgelintls }\end{array}$ & & $\cdot$ · \\
\hline Burley & & \\
\hline Burytes. & & . \\
\hline $13,1<11 \mathrm{t}$ &. & \\
\hline $13 x=5$ & & . \\
\hline lbasuince. & & \\
\hline B.3sswonkt & & \\
\hline H.ant filues & & \\
\hline H,it & & \\
\hline Banxite. & & \\
\hline Bayberry wat & & \\
\hline Bay 1 wox! & & \\
\hline lBuill vil. & & \\
\hline Beans. & & \\
\hline Bear & & \\
\hline $\begin{array}{l}\text { Benvet } \\
\text { Beche it met }\end{array}$ & & \\
\hline HeE & & \\
\hline Beech & & \\
\hline Beet & & \\
\hline Bee-wax & & \\
\hline Bee tree & & \\
\hline Beet sugat & & \\
\hline 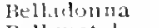 & & \\
\hline Bell metal & & \\
\hline Benzelle & & \\
\hline $\begin{array}{l}\text { Benzile } \\
\text { Benzoic icul }\end{array}$ & & \\
\hline $\begin{array}{l}\text { Benzoic acsl } \\
\text { Bensoin. }\end{array}$ & & \\
\hline $\begin{array}{l}\text { Benzoild } \\
\text { Berwarle }\end{array}$ & & \\
\hline $\begin{array}{l}\text { beyzule } \\
\text { heryl }\end{array}$ & & \\
\hline Betel & & \\
\hline Heverances. & & \\
\hline Bueleromate o & if $\mathrm{p}$ & antas \\
\hline livitite & & \\
\hline much. & & . \\
\hline Mirati & & \\
\hline Bitula Ine-nes & & \\
\hline lismuth & $\because$ & \\
\hline $\begin{array}{l}\text { Hisulphinle of } \\
\text { Bitumen }\end{array}$ & $c^{\prime \prime 1}$ & \\
\hline 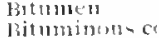 & onal & \\
\hline $\begin{array}{l}\text { Bjtuminom-ce } \\
\text { lslitch hean }\end{array}$ & & \\
\hline 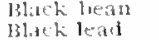 & & \\
\hline $\begin{array}{l}\text { Bluck leat } \\
\text { Bluckwoul }\end{array}$ & & \\
\hline $\begin{array}{l}\text { Blackwout } \\
\text { Blinlilet. }\end{array}$ & & \\
\hline $\begin{array}{l}\text { Blivldet } \\
\text { IHe }\end{array}$ & wite & et \\
\hline 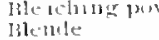 & & \\
\hline $\begin{array}{l}\text { lile-mule } \\
\text { Blout }\end{array}$ & & \\
\hline libluefial & . & \\
\hline islucomenue. & & \\
\hline Blue vitrol & & \\
\hline Boll weevil & & \\
\hline Bultinge cluth & & \\
\hline Buthe & & \\
\hline lbunte black & & \\
\hline Bumes fitt & & \\
\hline Btorax & & \\
\hline Burnite & & \\
\hline l3nit the & "ונים & \\
\hline $\begin{array}{l}\text { Buw-trilg be } \\
\text { Boxwerel }\end{array}$ & cill? & \\
\hline $\begin{array}{l}\text { Moxweral } \\
\text { Bran }\end{array}$ & & . \\
\hline Brabuly. & & \\
\hline Hrans" & & \\
\hline Brasi] wonul & & \\
\hline Brewing & & \\
\hline Brich & & \\
\hline Brin-tune & & \\
\hline Bribe . & & \\
\hline Bristles & & \\
\hline Britanuia we & & \\
\hline British gum & - & - \\
\hline lisodulcloth & & \\
\hline $\begin{array}{l}\text { Brocide } \\
\text { Bromelia }\end{array}$ & & \\
\hline $\begin{array}{l}\text { Bromelia } \\
\text { Bromine }\end{array}$ & & \\
\hline Bromvite & & \\
\hline
\end{tabular}

Bruluse

Broollicut

Brouls ront

lirusule end

brown liellatite

buckwheat

billiratone

Builulug stome

liallust

lintial?

linters.

littter, conoa

butletime

Butternilk

liutternat

Buttumbal

butnolat

Caceso

Ciaturim

Caffene

callinu

calcium cativle

calcitm stolutiate

Calt $=$ fout gelly

Lalfakin

cisica

calomel

cambrio

camel

campecle

camply

camphor t.ts

cannori

Camalud balman

Cimante

cindles

ciane ritt.tu

cane -tlog

Call un e (2.1)

Cantharales

Cauton Hannel

cautra

catralson

Carinel

Carawas

Cattwon

Cartenato

Carbomate of 5 s)

Cirtumbinglphitle

corbuld Itoxule

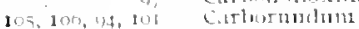

Cirdimuln

Cirmallite

carminth wis

Cirnclin

carmme

Cirpet

Cithollesio

Cissistida

Cillsitit

cantinete

Cansiteritc

Ciator lealu

Castoretula

Cat

catecill

cittioh

Ciatriat

Liat $n \in \mathbb{E}$

Cattle

catsotic pontan

Cindthe solut

Cist.1 re

heolat, Alatha

ceter, cigat-hos

cedist . Nonlmein

cedis, jencil

cendar. Port intherd

centir, red

Cedat, llent Inclitn.

cedar, white

entini

celestate

cillulun!

celluluste

Celluluse, aru path

cement

cement, lustand.

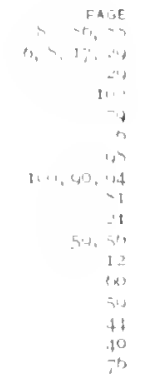

C

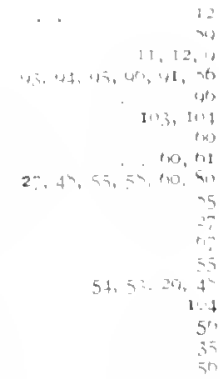

$52,54,23,2,34,14,73,71,44$, I

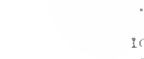

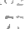

23 


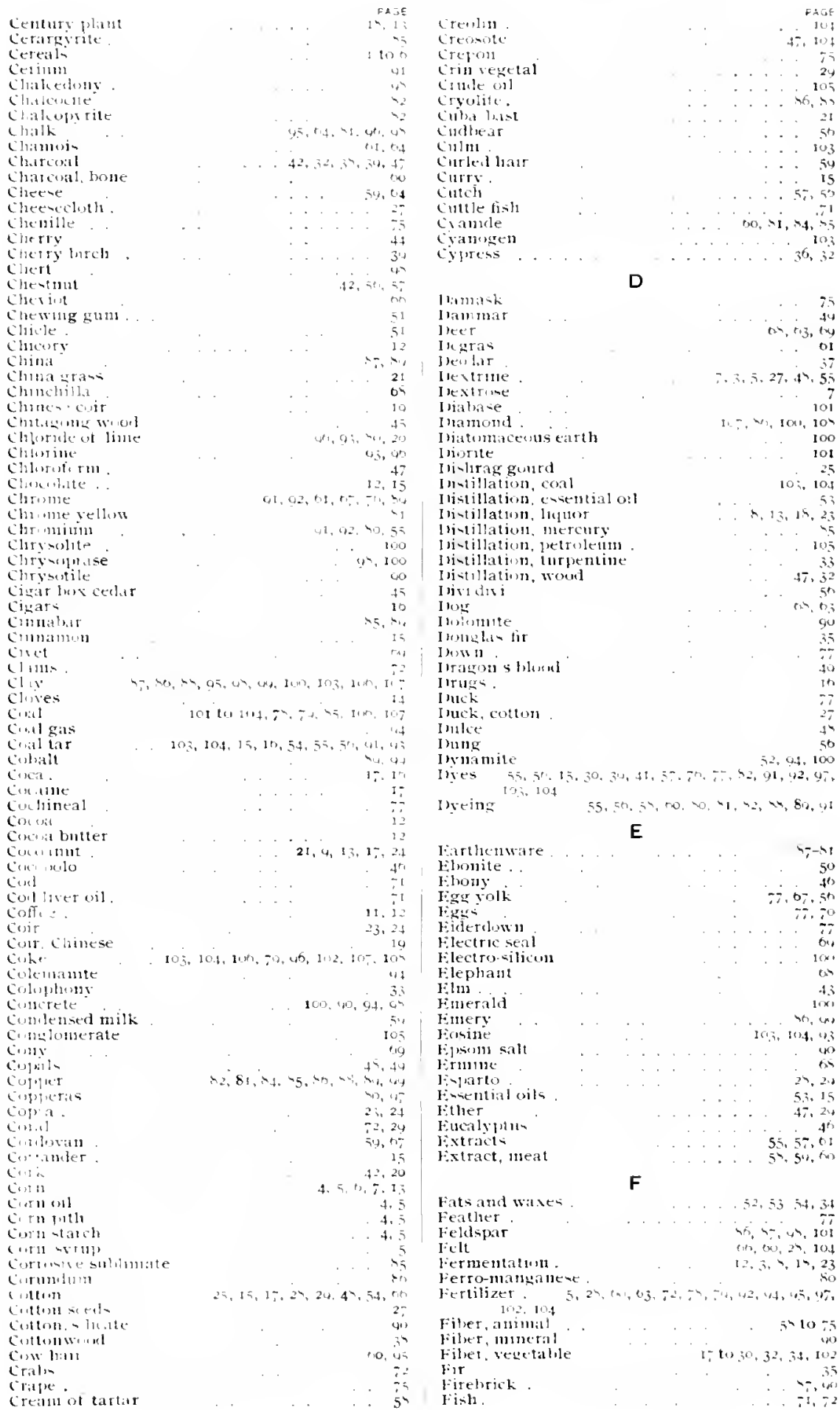


I'laghtone

flatunel

I"l.tsit

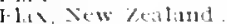

filemier-

filiust

Flaki-itk

Flont

Fhot harley

filous bealu

finurioles

Flunite

Fiux

Find:

Formaldehole

Fins

Frijules

f. ruit

Fullers eath

Fulminates

Fusm

Fusble metal

Filutito

G

ciaturio

craltella

challs

salvanized iton

Gambiet

Gamboge

Garbanzo.

Garinet

Gurrietite

Gas.

Gas, coal

Gan lume

Gas, natural

ras, wiater

fianolune

Cilluze

Cielatine

liens.

German silver

iilsonite

binker

ciugham

"Banconteste

blans

ilite

illucose

ilute

Gluten

Glitionalus tice

Slyecline

ritition

Goilts

Gold

Goldheater- thib

Grais

Gromilils

firmble

Citales

ciralue sugat

Graqlite

Graplite

cirasuclot

irete

circenbeat

creell का 1

irimistonte

Girits

itiano

i. Iitac

Gum, icacia

Gimu ammoniacum.

tilum. Angela

ium Arahe

inum. Batbar

imm, Britisty

imm, British

inul cherr

(inm, chewing

Gimm, dammar

timul, cray

illl, ruaiacums

iumini gutt

Giun, Kauri

Gium, 1,oangu?

Gum mesquite

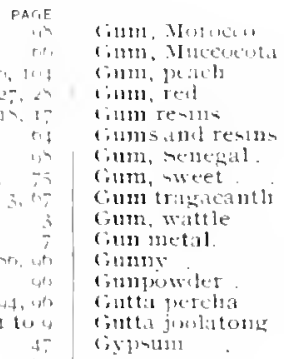

PAT,E

Cimm, M Inceuted

(inti1, peacl

inm, reil

fillum re-1110

iilms and resino

Cinm, serectal.

Gimm, swet

cumtrisacanti

Gumn, wattle

Cimu ductal

Cimany

immpower

Cintil peretera

int

(5)หูnu11

Jackmatack

livilock

H.1.15

I1. lite

liardwoots

llazel

Helintrope

Hematise

jematite, bown

IIemlock

lesulock tar

Heगมा

l1 mertuen.

II 1 แก

Iferon

I I trting

If (-Tia Ilate

Hickory

IIkles

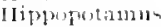

II)

Holly

I olot h 1 17\% 1.11

Itomijy

ffonte-tinge

tontey

I Intey-mele

II)

II

II (15)

Hurntistute

Horse

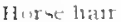

Hyirumlic centent

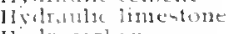

Ij)hrucarthom

livilroquinose

\section{H}

the

(t)

1

Julia linam

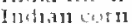

li]!'ly

lufunortal entth

$111 \mathrm{k}$

linatects

Jjuetet jowded

Intestintes

Jatine .

lonkefintis

Ipecence

Jivlium

Irinli nowes

Iri)

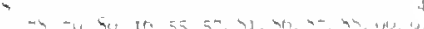
$12,14,45,49,103,109$

Inivglam

Ivety

Ixory, veretall

intle

Jatatand,

logentery

Tapan was

Jarral

Jingin.

Fel

findulyer

Jute"
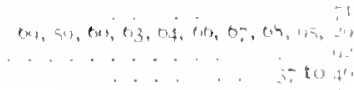$$
\text { in }
$$
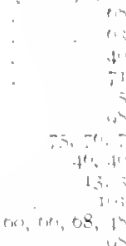

4
517

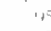

a co 3ix

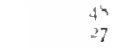

7

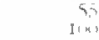

7207.57

$60,0.3,1.4$

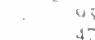

$4:$

Kisulite

Kinleitroo

Kanilin
J

k

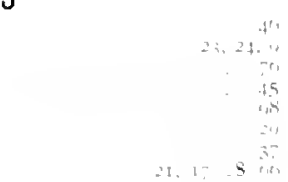




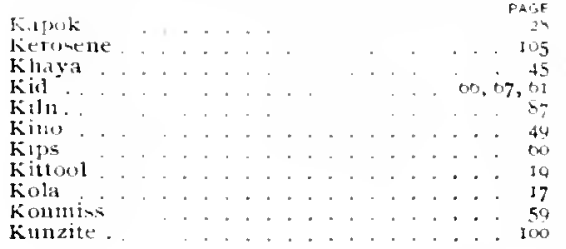

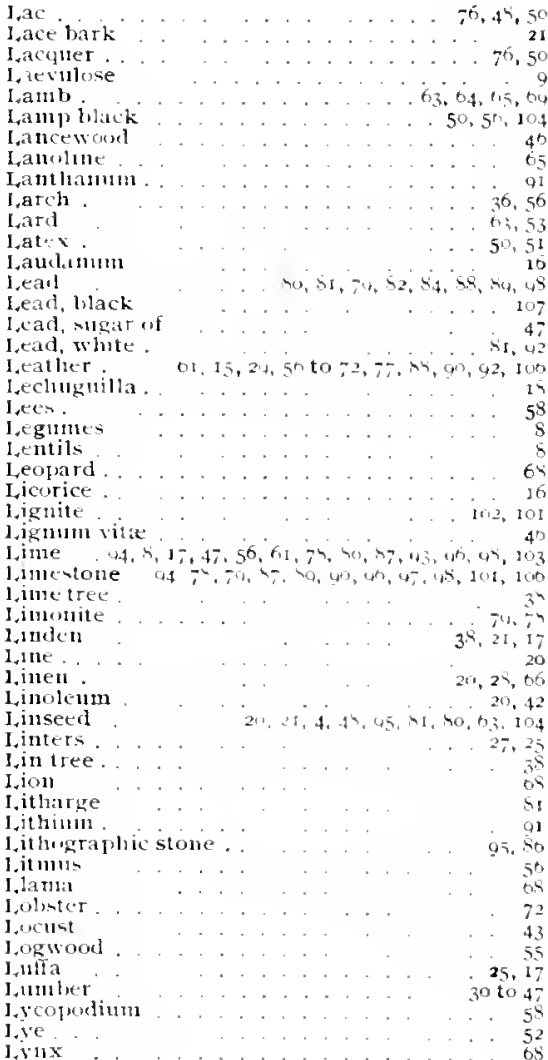

M

Mace

Mackerel:

Maldet

Iicmenia

Iagne-inm

Inanetite.

Matgluey .

Mahrigatuy

Maire

Irabelute

YLit

Najtlia

Malture.

Manganeso

Mallgrove.

Manila henin

Iaminot 1

Maple

Matble

Marl

Mititeil

Inatic

Mate

M
Matritius hemp

PAGE

Meal $54,54,03,64,04,6,70,71,77,44$ Medicine $26,23,4,49,50,53,54,77,58,59,91$,

Meerschituin

, go

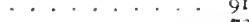

Netlthol st" st

Mercerizing

Mercury.

Herino .9 .69

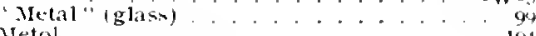

Metol . . . . . . . . . 104

Mexican whisk.

Nezcal . N

Mica. . . . . . . 100, 101, - . 1

Mica selist . 101

Middlitigs
Milk

$59,6.4,26,67$

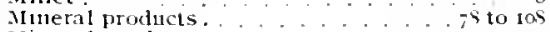

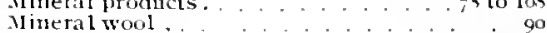

Mineral wool .
Minium.

Nink.................. 69

Mirlatie . . . . . . . . . 104, 54

Mirror ............ 5,99

Wohair . . . . . . . . . s 67

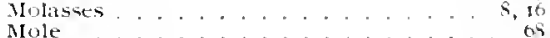

Mole

Molybdenum . . . . . . . . . . . 91

Monazite . . . . . . . . . . 91

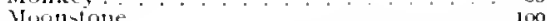

Morá

Moral
Iordani

Moroceo. . . . . . 64, 67

Mopphine
Mortar

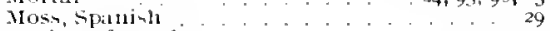

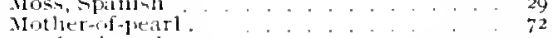

Monlmeincedar
VIucilage

Mucilage
Yuck
102

Hitick

Milite

Mink

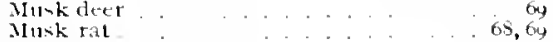

Mlikk ox . . . . . . . . 09

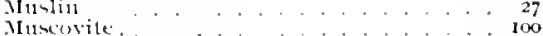

Musacle. . . . . . 72

Minatird 13

Mutton . . . . . . . 63,64

Mistiblan

Mirrli.

49

$N$

Naptha 104,105

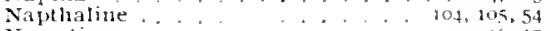

Narcotics.
Narwhal

Natural gas $\quad . \quad 101,99,105$

Neat'sfint oil ............ 60

New Zealand tax!. . . . . . . 15, 17

Nickel "." "." so, si

Nitrate of sidia .

Nitru-cellulose . . . . . . . . . . . . . 29

Nitrogen mie. . . 52, $91,100,105$

Noviculite. . . gh

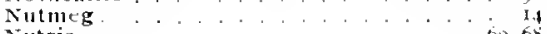

Nutria
Nute

Nits

O

Oak.

$40,41,42,46,47,56,57,61$

Oakint

coits.

icher.

(bil, almond.

Oil, leats 8,53

oil, bitter almomal ...... 53, 104

Dil, hown . . . . . . . . 52

(oil, cacas

oil cake

()il, cistunic

(1il, cantur

$4,5,20,23,24,52$

16,50

Dil. clove 


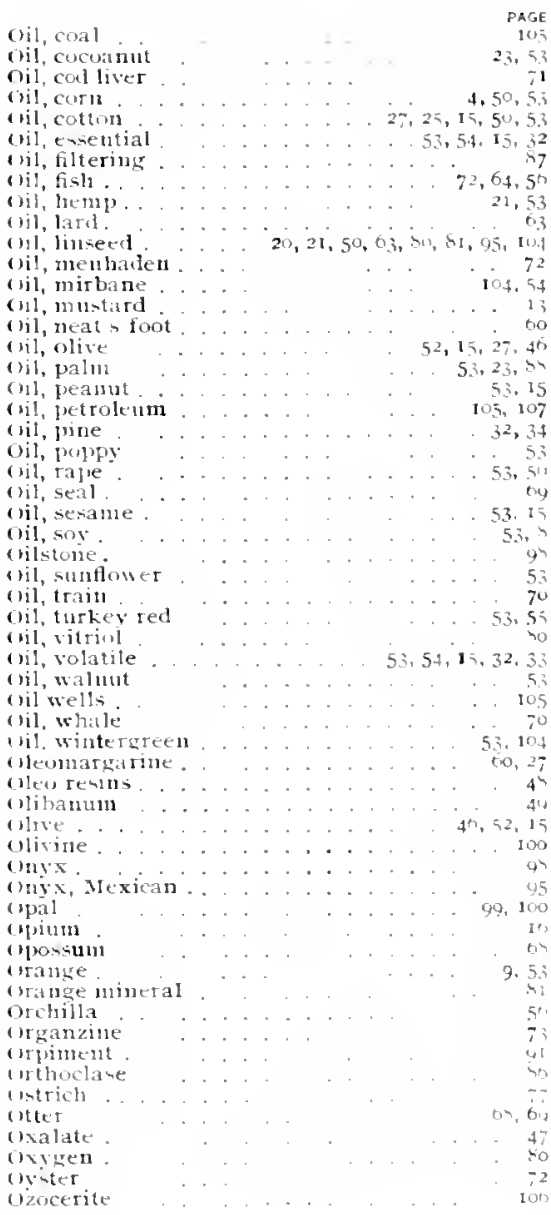

Fadiuk

Parlaty

'alme

lalinetto

Pa!no oil

Palmera fibet

I'anama strats

P:indanus

Pajer $24,5,6,7,17,1 \%, 20,21,27,29,34,35,39$ bo, $70,40,87,54,40,92,94,96,97,100,104,100$

Paper, imilberry

l'aper, tar

l'aper, waxed

l'apjer-maclie.

Paraftiue

Jatebment

Inatisgtent

I'tet but oil

l'eatl

Peatl barley

peas

leitit

Iecan

l'ela max

Pepsili

"evणि

'सpमte
I'tumes

I'rmambico wood

I'crian berries

Petrolatum

I'troleum
Pewter

Plieasint

'hlogropite

llospliates

Phosphaterock

Pliosphot litonze

l'hosphorus.

l'ia unilla

Iis

pigconse

J'is iron.

Pigmenis

I'illa. .

linte

Pincapple

line, ginget

Pine, Oregon

Inthe, Swise

I'inisu.

pintachuo

Initat

Fitch

pitel minex.1.

plabe.

phister

plater of paris

I"latiunm

I"lutmbats"

]"linnes

Flush

polylusite

Ponliger

Pujucorn

Ponlar Carulina

loplar, tulip.

Puty

Purcelain.

]utculfine woot

Purk

Purphyry

l'ortland cement

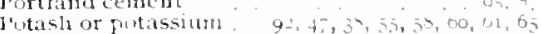

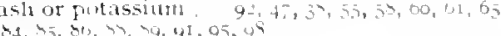

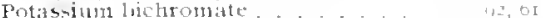

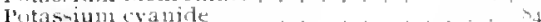

Putatis.

potiery.

Ponltri

jetate

Jima letel

Printersink

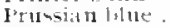

]'mlonitane

P’ulque

burple heat

jutty

Pviaryite

Irrethin

Ijotite

Pitolusite

rithotite

Q

Onistz

juartzite

Juebrach

Tuercitrou

culcklime

Guicksilver

inilli.

Guinine.

Rabluit

Raccust

Radinin.

Ramie

Raphia

Rat.

Rattan

Rawhin

Kaw sill

Realgar.

Rel ctolitr

Red gun

Red lead

Rerbood 


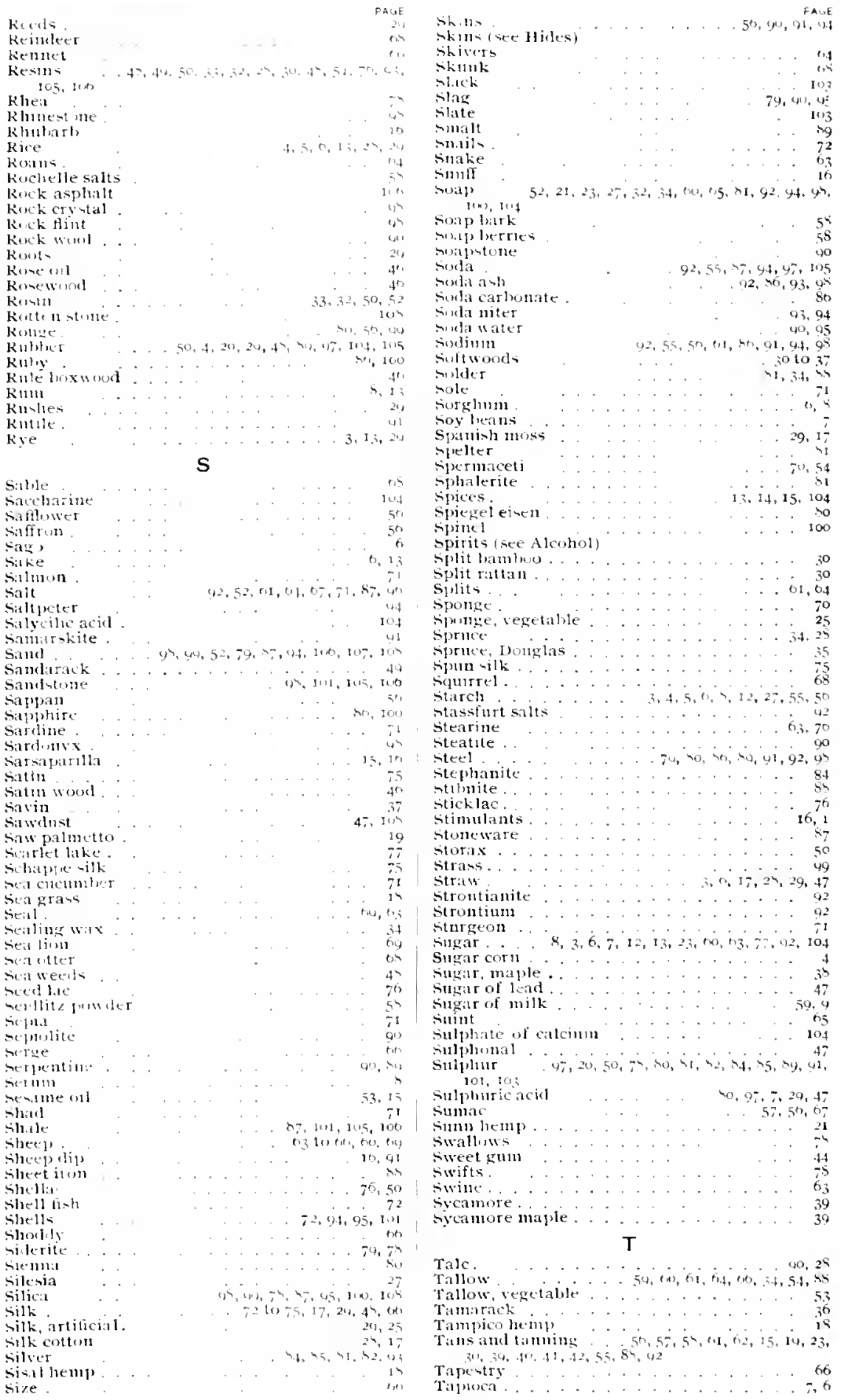




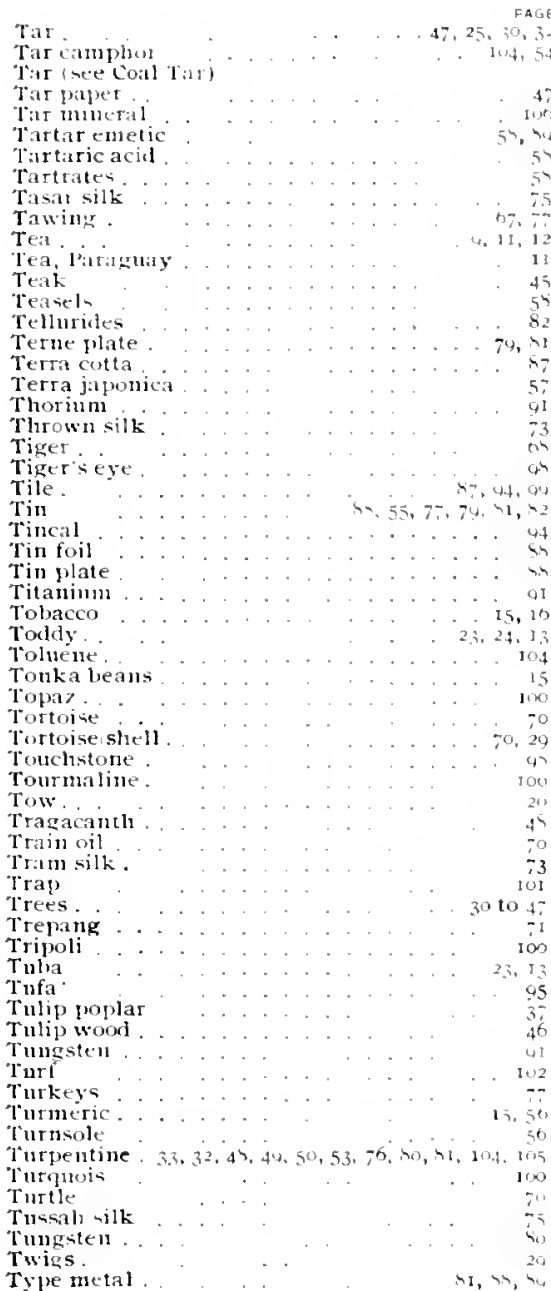

vinegat. songl

vitriol, pilute

Vitriol, filute
vitriol, gtcen

Vidka

Filatile

vinlautc

wond, distillation

Valonia

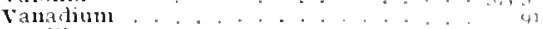
Ftnila

Vanilla extract . . . . . . . . 1 . . .

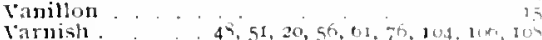

$47,51,20,56,01,75,104,114,104$

Vaseline

Vegretable vory

vegetalile probucts

16054,1710105

extaliles

vegetalie silk.

Vegetable sponge

Teluet

Vellum

Verd antique

vermillion

Vetch.

vituna"

villegat

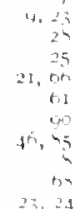

W:11100

Nilnut

Wialtus

lfabbing clay

viashing gold

vashing graphite

Waste, cottin.

vistes

Waste, silk

Waste, woolen

Wiattle bark

11: $x$

Wax, baylixerry

Wax, bee

Wax, carnauba

Wax, Cbine ne

wax, grafting

liax, insect

Wax, Japau

Wax, myrtlebersy

Wax, parafline

Wax, pela

Wax, sealing
Wax, shoemaber"s

Wax, sperm

Weak fisil

weasel.

whale.

Wheat

W'heat sisw

whetstone

white leart

White of ers

White metil

Whitewanl

Whitewoun

Whiting

Whiines
Wild cat

W'ild silk

willow

willow bark

vitle

Wine, kola

Wine, palu

Wich ha $7,-1$

Wolt

volverine

का

Wood - 30 to $4,2,24,2+54,55,57,57,49,4=$ 102, 10. 10., 108

Wood alcolust

Wond, petrified

Wond julp

Woout vinestar

15im,

ifocien.

IV(n)l lat

Win, mineral

Ninol jine

Norticd

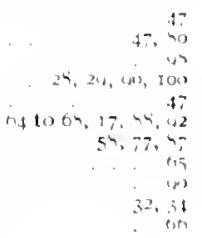

W

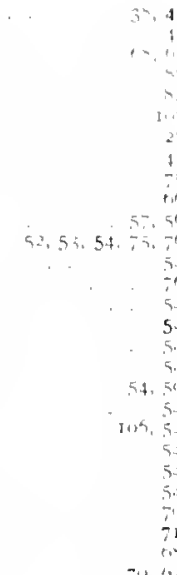

is

$1 \div$

15

15

54

5.6

54

54

Iamamai sth

laxes.

Yeant

Yellow berric

Fellow was

retha mate

rolk

Young fusti:

fttitum

ruca.

Y

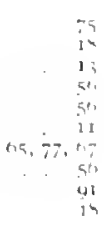

z

Ziscutom.

zince 


心 


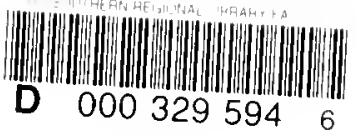


